\title{
COMPORTAMENTO DE PAVIMENTOS DE CONCRETO ESTRUTURALMENTE ARMADOS SOB CARREGAMENTOS ESTÁTICOS E REPETIDOS
}

\section{PATRÍCIA LIZI DE OLIVEIRA MAGGI}

Tese apresentada à Escola de Engenharia de São Carlos, da Universidade de São Paulo, como parte dos requisitos para obtenção do título de Doutor em Engenharia de Estruturas. 

Ao meu marido, Yuri 



\section{AGRADECIMENTOS}

Ao orientador, professor Libânio Miranda Pinheiro, pela sua preocupação em ajudar no meu crescimento.

À FAPESP, pela bolsa de estudos.

Aos professores do Departamento de Engenharia de Estruturas, pelos ensinamentos.

Aos professores Gilson Natal Guimarães e José Samuel Giongo pelas sugestões no exame de qualificação.

Aos funcionários do Departamento de Engenharia de Estruturas, pela disposição em ajudar.

Aos amigos que tornaram mais alegre o período de desenvolvimento deste trabalho.

Um agradecimento especial aos amigos: Kênia, Alio, Raïssa, Rodrigo, Suzana e Walter, companheiros de todas as horas.

Ao grupo de teatro Evoé, por me fazer perder o medo de platéia.

Aos professores Roberto Leon e Laurence Kahn por me receberem no Georgia Institute of Technology, durante o doutorado sanduíche.

Ao professor Jorge Miguel Proença, por me receber durante visita ao Instituto Superior Técnico de Portugal.

Aos meus irmãos, por me passarem confiança.

À minha sobrinha, pelo carinho.

Aos meus pais, por fazerem da educação dos filhos um objetivo de vida.

Ao meu marido Yuri, que com paciência e companheirismo tornou essa tese possível. 

SUMÁRIO

Sumário

Lista de símbolos__ iii

Resumo __ v $v$

Abstract__ vi

Introdução — 1

1.1 Justificativa _ _ 2

1.2 Objetivos__ 2

1.3 Metodologia __ 3

1.4 Estrutura do trabalho _ 3

Fadiga em concreto armado __ 5

2.1 Histórico dos estudos sobre a fadiga___ 6

2.2 Fadiga em estruturas de concreto armado ___ 8

2.2.1 Fadiga do concreto

2.2.2 Fadiga do aço para concreto armado _ـ 14

2.2.3 Fadiga do concreto armado___ 18

2.3 Modelos de fadiga___ 24

2.4 Verificação da segurança à fadiga ___ 31

2.5 Considerações finais___ 35

Modelagem numérica de pavimentos de concreto ___ 37

3.1 Modelos de pavimentos rígidos encontrados na literatura ___ 37

3.1.1 Bull (1991) _ 37

3.1.2 Al-khalid (1991) _ 39

3.1.3 Bull \& Salmo (1992)__ 48

3.1.4 Bull \& Woodford (1997)__ 48

3.1.5 Bull \& Woodford (1998) _ 52

3.1.6 Paliga \& Real (2003)__ 56

3.1.7 Buch (1999)__ 60

3.2 Modelagem numérica do concreto armado___ 61

3.2.1 Concreto tracionado _ 62

3.2.2 Armadura __ 65

3.3 Considerações finais___ 65

Ensaios de laboratório em pavimentos de concreto ___ 67

4.1 Losberg (1960)___ 68

4.1.1 Determinação da rigidez à flexão e do momento último ___ 70 
4.1.2 Procedimento de ensaio das placas 72

4.1.3 Discussão dos resultados ___ 74

4.2 Bull e Salmo (1992)__ 75

4.2.1 Procedimento de ensaio ___ 75

4.2.2 Discussão dos resultados__ 78

4.3 Roesler (1998) _ 78

4.3.1 Metodologia de ensaio ___ 78

4.3.2 Discussão dos resultados___ 82

4.4 Rodrigues (2003) _ 84

4.4.1 Metodologia de ensaio ___ 85

4.4.2 Discussão dos resultados___ 86

4.5 Considerações finais___ 87

Modelagem experimental___ 89

5.1 Primeira etapa ___ 89

5.1.1 Geometria __ 90

5.1.2 Preparação dos modelos __ 90

5.1.3 Esquema geral do ensaio e instrumentação __ 91

5.1.4 Resultados _ 93

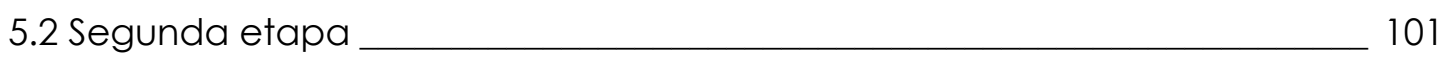

5.2.1 Geometria __ 101

5.2.2 Preparação dos modelos___ 102

5.2.3 Esquema geral do ensaio e instrumentação __ 102

5.2.4 Resultados __ 103

5.3 Terceira etapa __ 108

5.3.1 Geometria __ 108

5.3.2 Preparação dos modelos __ 109

5.3.3 Esquema geral do ensaio __ 111

5.3.4 Resultados _ 114

5.4 Considerações sobre a análise experimental _ـ 136

Modelagem numérica __ 139

6.1 Critérios gerais da modelagem__ 139

6.1.1 Materiais__ 140

6.1.2 Elementos__ 142

6.1.3 Contato__ 144

6.2 Modelo de viga de concreto armado___ 144

6.3 Placas apoiadas sobre meio elástico ___ 149

6.4 Considerações gerais sobre a modelagem numérica ___ 158 
Análise dos resultados 161

7.1 Fadiga 161

7.1.1 Vigas simplesmente apoiadas 161

7.1.2 Placas sobre apoio elástico 163

7.2 Análise paramétrica 167

7.2.1 Módulo de reação da fundação 168

7.2.2 Espessura da placa 169

7.2.3 Área de aço 173

7.2.4 Dimensões da placa 175

7.2.5 Posição da força e condições de contorno 177

Considerações finais 184

Conclusões 187

Sugestões para novas pesquisas 193

Bibliografia 195

Referências bibliográficas 195

Bibliografia complementar 204 



\section{LISTA DE SÍMBOLOS}

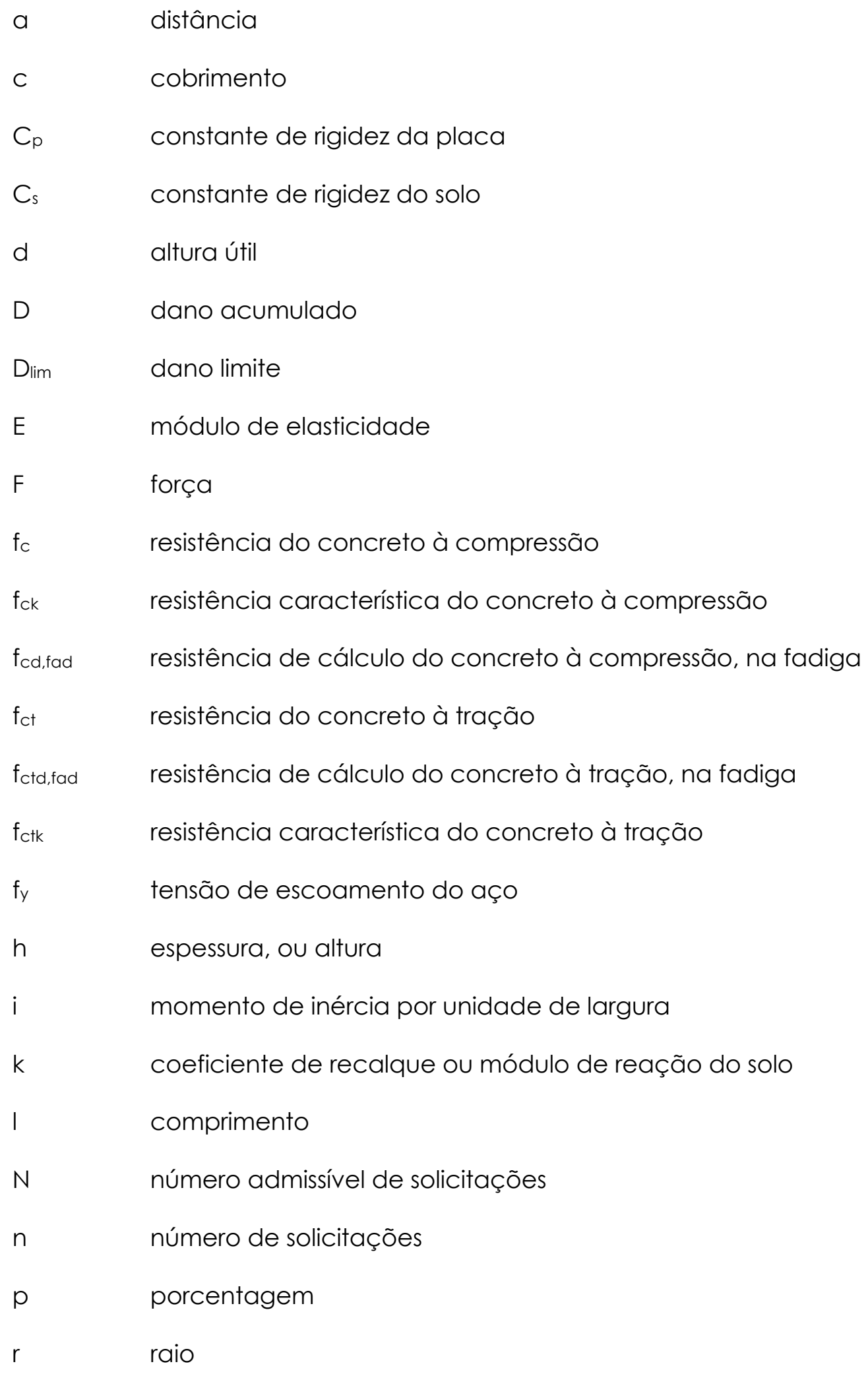




$\begin{array}{ll}R_{\dagger} & \text { relação de tensões, atuante e admissível } \\ W & \text { abertura de fissura } \\ \Delta l & \text { variação no comprimento } \\ \Delta \sigma & \text { variação de tensão } \\ \Delta \sigma_{R s k} & \text { resistência característica do aço à fadiga em } \\ \delta & \text { deslocamento } \\ \varepsilon & \text { deformação } \\ \varepsilon_{p} & \text { deformação plástica } \\ \gamma_{c, f a d} & \text { coeficiente de segurança à fadiga, para o concreto } \\ \gamma_{f} & \text { coeficiente de segurança à fadiga } \\ \gamma_{S d} & \text { coeficiente de segurança das ações } \\ \gamma_{s, f a d} & \text { coeficiente de segurança à fadiga para o aço } \\ \phi & \text { diâmetro } \\ \eta_{c} & \text { coeficiente de gradiente de tensões } \\ \nu & \text { tensão } \\ \sigma & \text { tensão de compressão no concreto } \\ \sigma_{c} & \end{array}$




\section{RESUMO}

MAGGI, P.L.O. (2004). Comportamento de pavimentos de concreto estruturalmente armados sob carregamentos estáticos e repetidos. São Carlos, 205p. Tese (Doutorado) - Escola de Engenharia de São Carlos, Universidade de São Paulo.

Apresenta-se um trabalho numérico e experimental, com o objetivo de estudar o comportamento dos pavimentos de concreto estruturalmente armados, quando submetidos a forças verticais estáticas e repetidas. Avalia-se a contribuição da armadura de flexão, na resistência de placas de concreto apoiadas sobre meio elástico. Verifica-se experimentalmente o modo de ruína de placas submetidas a carregamento monotônico e a carregamento repetido, com e sem armadura, e acompanha-se o desenvolvimento das fissuras no concreto e das deformações no aço. Comparam-se os resultados obtidos, com as recomendações da NBR 6118:2003, para o dimensionamento de estruturas submetidas à fadiga. É desenvolvido modelo numérico capaz de representar a interface do solo com a placa do pavimento, a fissuração do concreto, a contribuição da armadura e o comportamento pós-fissuração. Com auxílio do modelo numérico, validado a partir dos resultados experimentais, estuda-se a influência de alguns parâmetros importantes para o dimensionamento dos pavimentos, tais como: capacidade de suporte da fundação, espessura das placas, área de aço, dimensões das placas em planta, posição de aplicação da força e presença de juntas de transferência de deslocamento. Os resultados experimentais mostram uma significativa contribuição da armadura positiva na resistência de placas isoladas sob forças verticais centradas. Verificou-se que as forças repetidas provocam fadiga do aço e que o número de ciclos depende da deformação provocada na armadura. A partir dos resultados são traçadas diretrizes para o dimensionamento, no qual devem ser considerados os momentos positivos e os negativos, e deve ser feita a verificação da fadiga do concreto e da armadura.

Palavras-chave: pavimentação; pavimento; piso; pavimento de concreto armado; fadiga; modelagem numérica; carregamento repetido. 


\section{ABSTRACT}

MAGGI, P. L. O. (2004). Structurally reinforced concrete pavement behavior under static and cyclic loads. São Carlos, 205p. Thesis (Doctorate) - Escola de Engenharia de São Carlos, Universidade de São Paulo.

A numerical and experimental study on the behavior of structurally reinforced concrete pavement under vertical static and repeated load is presented. The contribution of bending reinforcement to the strength of concrete slab is assessed. It is experimentally verified the fracture of reinforced and plain concrete slabs under monotonic loads and under cyclic loads. The concrete cracking and the strain on steel are monitored. The results are compared to the Brazilian code recommendations to the design of structures under fatigue. A numerical model that represents the soil-slab interface, the concrete cracking, the reinforcement contribution and the tension stiffening behavior is developed. Some important parameters to the pavement design are analyzed using this Finite Element model, whose reliability was verified to experimental results. These parameters are: the soil capacity; the slab thickness; reinforcement ratio; slab dimensions; load positions; and joints conditions. The tests data show an important contribution of the positive reinforcement on the strength of an isolated slab with centered load. It has been verified the fatigue of the steel. The number of cycles depends on the reinforcement strain. The results are used to propose some directions to the design. The positive and negative bending moments have to be considered and the fatigue on the concrete and on the reinforcement has to be verified.

Key words: pavement; floor; reinforced concrete pavement; fatigue; numerical model; cyclic tests. 
No projeto de um pavimento de concreto pode-se considerar placa não fissurada ou fissurada. Na primeira opção as tensões de tração devem ser limitadas à resistência do concreto. Na segunda, a placa deve ser armada para limitar a abertura das fissuras (Walker \& Holland, 2001).

Os pavimentos de concreto que possuem armadura próxima à face inferior, com o objetivo de resistir às tensões provenientes do momento fletor, são chamados de Pavimentos de Concreto Estruturalmente Armados. Esse tipo de pavimento pode ser construído com espessuras inferiores às dos pavimentos de concreto simples, pois a força última não depende exclusivamente da resistência à tração do concreto.

Os pavimentos de concreto estruturalmente armados podem ser executados in loco, ou serem compostos de unidades pré-fabricadas. Segundo El Debs (2000) as vantagens da pré-moldagem são: grande reutilização das fôrmas, melhor aproveitamento dos materiais, maior produtividade da mão de obra e maior controle de qualidade. Rollings (1991) afirma que os pavimentos de concreto são candidatos viáveis a pré-moldagem por serem constituídos de um número muito grande de placas iguais. Os pavimentos pré-moldados apresentam as desvantagens de exigirem base muito regular e dificultam o uso de dispositivos de transferência de deslocamentos. Sua maior vantagem é a rapidez de construção e velocidade de abertura ao tráfego.

Segundo Kennedy (1991), os pavimentos de concreto podem ser construídos com armadura apenas na parte superior quando são solicitados por ações moderadas ou leves, mas em caso de grandes solicitações, como em aeroportos, defende a utilização da armadura inferior. A armadura superior tem a função de restringir a fissuração por causa dos efeitos de retração e temperatura, que dependem das dimensões da placa e, segundo Silfwerbrand (1999), da rigidez do solo. 
Quando o pavimento é submetido a forças elevadas, distribuídas em pequenas áreas, a utilização de armadura positiva, ou da protensão, torna-se mais adequada. Desta forma, os pavimentos de concreto estruturalmente armados podem ser utilizados em vias urbanas, principalmente em corredores de ônibus, terminais e pátios de manobra onde há um tráfego intenso, em pisos industriais, em praças de pedágio e em pistas de aeroportos.

1.1 JUSTIFICATIVA

Segundo Owusu-Antwi \& Darter (1999), os métodos de dimensionamento de pavimentos de concreto precisam ser revistos, a fim de prever seu desempenho durante a vida útil.

A maioria dos modelos disponíveis para dimensionamento de pavimentos leva em conta métodos analíticos simplificados, como o de Westergaard (1926). Com o avanço dos métodos computacionais é possível desenvolver modelos mais complexos que considerem outros fatores, inclusive o comportamento não-linear dos materiais, a interação do concreto com a armadura, o contato entre a placa e o solo, diferentes configurações de carregamento e condições de contorno.

A NBR 61 18:2003 apresenta critérios de fadiga para o concreto e para o aço para concreto armado, visando o dimensionamento de vigas. A utilização destes modelos no dimensionamento de pavimentos de concreto ainda precisa ser avaliada.

\subsection{OBJETIVOS}

Este trabalho tem o objetivo principal de analisar o comportamento de placas de pavimento de concreto estruturalmente armado quando submetidas a carregamento vertical estático e repetido, avaliando o efeito da fadiga em placas armadas com tela soldada.

Procura-se determinar o modo de ruína desse tipo de estrutura e avaliar a influência de alguns fatores na resposta do pavimento às solicitações. Os parâmetros estudados são: espessura da placa, taxa de armadura, resistência do 
concreto, módulo de reação do solo, dimensões, posição da força e condições de contorno.

\subsection{METODOLOGIA}

Buscando cumprir os objetivos, foi realizada uma pesquisa bibliográfica abrangendo tópicos relacionados com a pesquisa.

Foi desenvolvido um programa experimental onde se avalia o comportamento de placas de concreto armado apoiadas sobre meio elástico, submetidas a forças estáticas e a carregamentos repetidos, e onde se definem parâmetros necessários à modelagem numérica.

O modelo numérico, desenvolvido com auxílio de programa computacional com base no método dos elementos finitos, permite a verificação dos esforços, deslocamentos e deformações nas placas de concreto armado, apoiadas sobre meio elástico e submetidas a forças diretas verticais estáticas. O modelo foi validado a partir dos resultados experimentais e utilizado para uma análise da influência de parâmetros importantes no dimensionamento dos pavimentos de concreto estruturalmente armados.

\subsection{ESTRUTURA DO TRABALHO}

Esta tese de doutorado é dividida em oito capítulos. No primeiro é realizada uma introdução ao assunto, definindo o que é pavimento de concreto estruturalmente armado e apresentando os objetivos da pesquisa.

Os capítulos dois, três e quatro consistem na revisão bibliográfica que foi dividida em: fadiga do concreto armado; modelagem numérica dos pavimentos de concreto; e ensaios em pavimentos de concreto.

No capítulo cinco é descrita a metodologia empregada no desenvolvimento da modelagem experimental e os resultados obtidos nos ensaios realizados em laboratório. 
O capítulo seis mostra o desenvolvimento de um modelo numérico que representa o comportamento de placas de concreto armado apoiadas sobre o solo e sua validação estabelecendo comparações com os resultados experimentais.

No capítulo sete são avaliados os resultados numéricos e experimentais obtidos. Utilizando o modelo numérico desenvolve-se uma análise paramétrica mostrando a influência de alguns fatores importantes para $\bigcirc$ dimensionamento dos pavimentos de concreto estruturalmente armados.

No último capítulo são apresentadas as conclusões que se obtiveram no desenvolvimento deste trabalho e as sugestões para novas pesquisas. 


\section{FADIGA EM CONCRETO ARMADO}

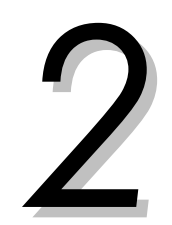

A fadiga refere-se, segundo Suresh (1991), ao dano e à ruptura de materiais submetidos a carregamento cíclico e é caracterizada por uma mudança nas suas propriedades.

Do ponto de vista da engenharia a fadiga pode ser definida como um modo de ruptura que envolve a formação e o crescimento de uma fissura num componente estrutural sob carregamento variável no tempo, cuja amplitude máxima induz tensões inferiores à resistência do material utilizado.

Lloyd et al. (1968) definiram a fadiga como um dano estrutural progressivo e permanente no material submetido a tensões e deformações flutuantes no tempo. Este dano estrutural pode culminar em microfissuras ou na fratura completa, após um certo número de ciclos.

O ACl 215R:1992 diferencia carregamento dinâmico de estático da seguinte forma: o carregamento dinâmico varia no tempo de maneira arbitrária. A fadiga e o impacto são casos específicos de carregamento dinâmico. A fadiga consiste numa seqüência de carregamentos cíclicos que pode causar ruptura com mais de 100 ciclos. Forças cíclicas, provenientes de catástrofes como terremotos, são chamadas de low-cycle fatigue, e têm tratamento distinto da fadiga (high-cycle fatigue).

O capítulo referente à fadiga na NBR 61 18:2003 limita-se a solicitações entre 20.000 e 2.000.000 de ciclos.

Neste trabalho, será chamado de carregamento cíclico aquele que é aplicado várias vezes numa estrutura, podendo haver inversão de sinal. O carregamento repetido fica definido como um caso particular do carregamento cíclico onde não há inversão do sinal da força. 
Os métodos de dimensionamento de pavimentos de concreto simples adotam diferentes modelos de fadiga, com base em ensaios de laboratório ou em pistas experimentais. Porém, segundo Vandenbossche (1995), os pavimentos de concreto armado atingem a ruína prematuramente por causa da desconsideração da fadiga no dimensionamento da armadura. Mesmo os pavimentos que possuem armadura suficiente para resistir aos limites de tensão determinados para carregamentos estáticos vêm apresentando aberturas de fissuras excessivas, defeitos e perda da capacidade de suporte da fundação.

\section{1 HISTÓRICO DOS ESTUDOS SOBRE A FADIGA}

Segundo Suresh (1991), os primeiros relatos sobre fadiga foram escritos por volta de 1829, quando o engenheiro alemão W. A. J. Albert realizou alguns ensaios em correntes de aço usadas nas mineradoras.

Os estudos sobre fadiga se intensificaram após um acidente na ferrovia próxima a Versalhes, em 1842. Em 1843, Rankine, um engenheiro inglês, reconheceu as características distintas da ruína por fadiga e observou o perigo das concentrações de tensão em componentes mecânicos. Em 1849 o governo inglês encarregou E. A. Hodgkinson de estudar a fadiga do aço empregado nas ferrovias. Em 1860, Wöhler conduziu uma série de investigações sistemáticas a respeito da ruína por fadiga em eixos ferroviários produzidos pela indústria alemã. Ele observou que a resistência dos eixos submetidos a ações cíclicas era significativamente inferior à resistência dos eixos submetidos a ações estáticas. Wöhler reuniu uma série de dados no formato ainda em uso nos dias de hoje: as chamadas curvas S-N (Stress-Number), ou curvas de Wöhler.

Em 1910, o americano O. H. Basquin representou a curva de Wöhler em forma logarítmica e propôs a fórmula:

$\sigma_{a}=C \cdot K^{n}$

Palmgren, em 1924, foi quem primeiro sugeriu um modelo linear de dano por fadiga, no qual é possível considerar o efeito do histórico da aplicação das ações, por meio do acúmulo do dano que cada intensidade de tensão provoca no material. 
Miner (1945) apresentou uma equação linear de dano por fadiga, hoje conhecida como modelo de Palmgren-Miner. Este modelo estima um valor de dano acumulado para um espectro de ações correspondente a uma probabilidade de ruptura, para um determinado número de ciclos. A ruína por fadiga se dá quando $\sum \mathrm{n} / \mathrm{N}=1$, sendo $\mathrm{n}$ o número de ciclos solicitantes para uma determinada intensidade de tensão e $\mathrm{N}$ ○ número admissível de ciclos para essa mesma intensidade.

Segundo $\mathrm{OH}$ (1991), a soma do dano acumulado, seguindo o modelo linear de Palmgren-Miner, é maior que um quando a intensidade da tensão aumenta gradualmente e menor que um quando antes é aplicada uma tensão mais alta.

AGARWAL et al. (1994) afirmam que curvas de fadiga, com base em ciclos constantes, podem resultar em projetos contra a segurança, em casos onde 0 carregamento é variável e tem natureza transiente. Propõem a utilização de princípios probabilísticos na consideração da fadiga.

Segundo O'Neill (1970), citado por Driemeier (1995), não é comprovado que alguma teoria não-linear de acumulo de dano forneça valores mais precisos que - modelo linear, e todas elas exigem mais dados experimentais, perdendo praticidade.

Depois da Segunda Guerra Mundial, passou-se a estudar com mais intensidade o fenômeno da fadiga, principalmente em aviões e automóveis. Em 1951, foi fundado o Comitê Internacional em Fadiga Aeronática.

Em 1954 o alemão Gassner descreveu o estado da arte dos ensaios de fadiga, no campo automobilístico e aeronáutico. Foi ele quem introduziu o termo "resistência à fadiga". A resistência à fadiga é expressa como uma porcentagem da resistência estática. A principal vantagem de se representar a resistência à fadiga como uma fração da resistência estática é que se eliminam os fatores que influenciam em ambas as resistências. Como exemplo pode-se citar, no caso do concreto, o fator água-cimento, as condições de cura e a idade do concreto que, segundo Raithby (1979), não são importantes quando a tensão aplicada é representada como uma fração da resistência estática. 
A seguir será estudado o comportamento do concreto, do aço e do concreto armado quando submetidos a ações cíclicas. Mallet (1991) apresenta um estadoda-arte sobre a fadiga do concreto armado, mostrando primeiramente as particularidades do concreto e do aço, separadamente.

\subsubsection{FADIGA DO CONCRETO}

No concreto, a fadiga começa em uma escala microscópica e é associada ao aumento da abertura das fissuras e à redução da rigidez. O ACl 215R:1992 afirma que a ruptura por fadiga ocorre por uma microfissuração interna progressiva. Por isso, ocorre um grande aumento nas deformações longitudinais e transversais.

Segundo o boletim do CEB (1988), no concreto, as fissuras por fadiga não têm uma topografia superficial definida, diferente do aço. Por essa razão é muito difícil identificar a fadiga nas estruturas de concreto. A fadiga pode ocorrer num elemento estrutural de concreto quando se desenvolve fissuração excessiva ou deformação excessiva. Segundo o boletim do CEB (1988), até o ano em que foi escrito, não havia, na maioria dos países, regras para dimensionamento das estruturas de concreto sob fadiga. Mais tarde, o próprio CEB-FIP Model Code 1990 (1991b) já apresenta um procedimento de verificação, seguindo o modelo de Palmgren-Miner. A NBR 6118:2003 também apresenta um capítulo destinado à verificação das estruturas de concreto à fadiga.

Diversos fatores podem afetar o comportamento e a resistência do concreto à fadiga. Entre eles pode-se citar: variação de tensão, histórico das ações, propriedades dos materiais, freqüência das ações, gradiente de tensão e períodos de folga. Segundo Barson \& Rolfe (1987) fatores externos como a temperatura e a agressividade do meio também afetam o comportamento à fadiga.

Quanto à variação de tensão, a resistência à fadiga aumenta com a redução do intervalo entre a tensão mínima e a tensão máxima. Isto significa que, para uma mesma intensidade de tensão máxima, a resistência à fadiga será maior quando a tensão mínima for maior.

Se um material for solicitado por diferentes intensidades de tensão, a resistência é menor quando forem aplicadas primeiro tensões mais altas. Schütz (1993) mostra a 
importância dos dados sobre o carregamento na análise da vida útil de uma estrutura, com relação à fadiga. Entre os erros de projeto que podem afetar a vida útil de uma estrutura, cita a ocorrência de grandes ações não previstas, que mesmo ocorrendo poucas vezes provocam fissuras que se propagam sob forças repetidas de menor intensidade.

A fadiga é caracterizada pela propagação de fissuras a partir das saliências ou dos microdefeitos dos materiais. Portanto, dependendo da sua composição, ele será mais ou menos resistente a esse fenômeno. No caso do concreto, por exemplo, a presença de ar incorporado reduz a vida à fadiga.

Raithby \& Galloway (1974) realizaram ensaios em vigas de concreto simples e verificaram que para freqüências superiores a $20 \mathrm{~Hz}$ a taxa de aplicação do carregamento não afeta sua resistência à fadiga. Alguns pesquisadores, como McCall (1958), Galloway \& Raithby (1973), Sparks \& Menzies (1973), Van Leeuwen \& Siemes (1979), Holmen (1979) e Cornelissen \& Reinhardt (1984), afirmam que, para intensidades de tensão acima dos $75 \%$, a resistência aumenta com taxas de carregamento maiores.

Quando um corpo-de-prova é solicitado por uma força axial, sua resistência à fadiga é menor se comparada com as solicitações que provocam um gradiente de tensões, ou seja, quando a tensão máxima não ocorre em toda seção transversal.

Apesar da necessidade de mais estudos sobre o assunto, sabe-se que os períodos de folga favorecem a resistência à fadiga dos materiais, assim como a manutenção da força entre os ciclos de carregamento.

Na tabela 2.1 é apresentado um resumo do desenvolvimento do estudo da fadiga no concreto, as referências marcadas com * são citadas por Mallet (1991).

Tabela 2.1 - Evolução geral das pesquisas sobre fadiga no concreto Autor (ano) Descrição

Van Ornum Primeira curva de fadiga para corpos-de-prova cúbicos de (1903)* concreto submetidos à compressão (figura 2.1). 


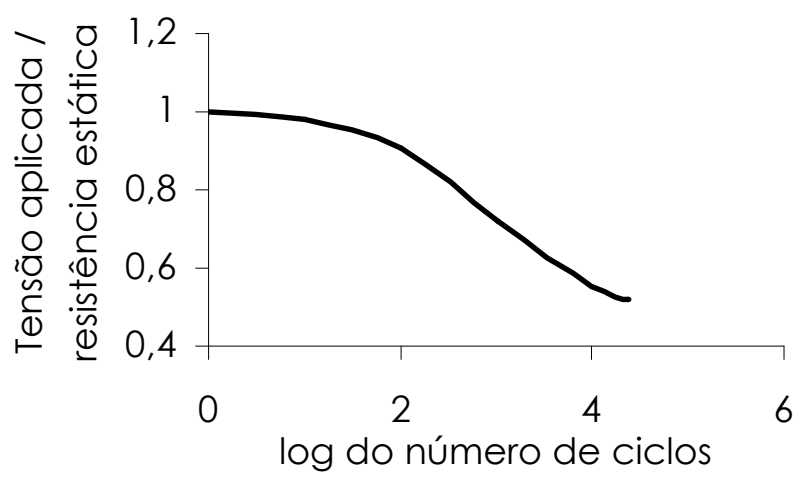

Figura 2.1 - Curva de resistência à fadiga do concreto (Van Ornum, 1903)

Van Ornum não encontrou um limite de fadiga para o concreto estudado. Mas concluiu que aquele concreto tinha resistência à fadiga igual a 55\% da resistência estática, para uma vida de 7000 ciclos. Posteriormente outros pesquisadores encontraram a mesma porcentagem para repetições acima dos 10 milhões de ciclos.

Van Ornum observou ainda a mudança do diagrama tensãodeformação conforme o número de repetições crescia, sendo inicialmente côncavo em relação ao eixo das deformações e se tornando convexo, conforme a rigidez diminuía.

Griffith (1922)* Sugeriu que a taxa de energia de deformação liberada na fissura de ruptura por fadiga é a mesma que na fissura que provoca a ruptura sob carregamento estático.

Williams (1943)* Concluíram que o limite de fadiga para o concreto realmente não e existe. Em geral os pesquisadores concordam que para concretos Kesler (1953)* convencionais a resistência à fadiga é de $55 \%$ da resistência estática, para 10 milhões de ciclos de carregamento.

McCall (1958)* Sugeriu que as curvas tensão-número de ciclos são traçadas a partir de uma probabilidade de ruptura, portanto é um conceito estatístico.

Assimacopoulos Pesquisas na Universidade de Lehigh mostraram que a ruptura à et. Al. (1959)* fadiga tendia a ocorrer na interface da matriz com o agregado, para quaisquer taxa de arenito de $9 \mathrm{~mm}$ e cascalho de quartzo (agregados utilizados nas pesquisas).

Kaplan (1962, Considerando a formação e o crescimento de fissuras sob 1965)* carregamento estático, sugeriu que o início do processo de ruptura ocorre por formação de múltiplas fissuras na argamassa, onde o agregado funciona como obstáculo à propagação. Ele associou a fissuração com a energia de deformação e, segundo Mallet (1991), é razoável assumir que o carregamento repetido tem comportamento similar.

Glucklich (1965)* Estudou o efeito da microfissuração na fluência e na fadiga, utilizando vigas de argamassa submetidas à flexão. Confirmou que - mecanismo de fadiga do concreto começa na ruptura da ligação entre a matriz de cimento e o agregado. A fissura se 
propaga pela argamassa, até que encontra um agregado. Quando a energia de deformação liberada ultrapassa as forças de coesão remanescentes, ocorre a ruptura completa do concreto.

Murdook \& Sugeriram que a relação entre a tensão mínima e a tensão máxima Kesler $(1958)^{*}$ e afeta a resistência à fadiga.

Aas-Jakobsen

(1970)*

Hilsdorf \& Kesler

(1960)

Descobriram que, para corpos-de-prova de diferentes tamanhos, a deformação média na ruptura por fadiga, na tração ou na flexão, era a mesma. A deformação última na fadiga é maior que nos ensaios estáticos. A relação da deformação com o número de ciclos é não linear e depende da seqüência de aplicação do carregamento.

Sinha et. Al. Desenvolveram expressões para a curva envoltória dos então (1964)* chamados ciclos pós-pico. As curvas pós-pico para o concreto à tração relacionam a abertura de fissuras com a tensão. Esse estudo é importante na aplicação de modelos não-lineares de fratura para concreto.

Awad \& Hilsdorf Ensaiaram prismas de concreto submetidos à compressão axial e (1974)* verificaram que, sob força repetida, a deformação final, na ruptura, aumenta se o nível de tensão ou a taxa de carregamento diminuem. Verificaram ainda que altos carregamentos repetidos ou sustentados causam uma redução significativa na resistência, apenas depois que 30 a $70 \%$ do número de ciclos de ruptura foram aplicados. O dano causado pela carga elevada repetida depende tanto do número de ciclos aplicados quanto do tempo total que essa força elevada foi sustentada.

Takhar, Jordaan Ensaiaram cilindros de concreto a fim de verificar a influência da \& Gamble pressão de confinamento. Os resultados dos testes indicaram que, (1974) para um nível de tensão máxima de $80 \%$ da resistência estática e tensão mínima de 20\%, a vida à fadiga aumenta com o confinamento lateral. Esse efeito foi menos evidente para níveis superiores de tensão.

Helagson \& Concluíram que a vida à fadiga, em escala logarítmica, pode ser Hanson (1974) representada por uma curva normal.

Tepfers \& Kutti Apresentaram um diagrama mostrando a influência da relação $R_{\dagger}$ (1979)* entre a tensão mínima e a tensão máxima na resistência do concreto à fadiga (figura 2.2). 


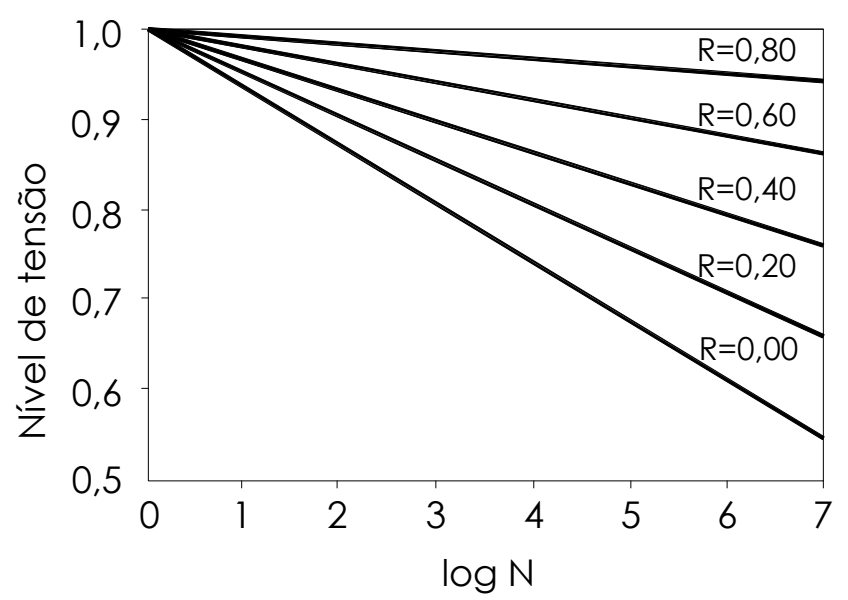

Figura 2.2 - Efeito da relação entre a tensão mínima e a tensão máxima - Rt - (Tepfers \& Kutti - 1979)

Holmen (1979) Estudou a deformação longitudinal em ensaios de fadiga por compressão. A deformação total tem duas componentes: $\varepsilon_{\text {máx }}=\varepsilon_{\mathrm{e}}+\varepsilon_{\dagger}$, onde $\varepsilon_{\mathrm{e}}$ está relacionada com a rigidez e inclui as deformações elásticas e $\varepsilon_{\mathrm{t}}$ é dependente do tempo, analogamente à fluência. Em geral a deformação ocorre em três estágios: um aumento rápido, aproximadamente nos $10 \%$ da vida total, um crescimento uniforme entre 10 e $80 \%$ da vida, e finalmente um aumento rápido até a ruptura. Observou ainda um acréscimo na deformação elástica com o número de repetições e redução do módulo secante.

Sparks (1982) Realizou estudos sobre o estágio de deformação uniforme e relacionou a taxa de deformação por ciclo com o número de ciclos até a ruptura.

Traina \& Jeragh Constataram que a resistência do concreto à fadiga é maior em (1982) e um estado biaxial de tensões, se comparado com um estado SU \& Hsu (1988) uniaxial.

Guolee (1983)* Sugeriu que a deformação residual poderia ser usada como parâmetro para medir o dano por fadiga.

Saito \& Imai Encontraram curvas aproximadamente constantes para a (1983) deformação elástica e verificaram que o acréscimo na deformação total se deve ao acréscimo da deformação residual, conforme aumenta o número de ciclos.

Tepfers, Relataram um método de previsão do dano e da vida à fadiga Hedberg \& através da absorção de energia que ocorre na zona de Szczekocki (1984)

Cornelissen \& Relacionaram a taxa de deformação a cada ciclo de tensão com Reinhardt (1984) o número admissível de repetições e verificaram ainda a validade do critério de Palmgren-Miner para a ruptura por fadiga. Sugeriram que as tensões alternadas diminuem a resistência do concreto à fadiga. 
Rings (1986)* Demostrou uma redução na resistência à compressão, devida a pequenos ciclos de tração.

Kim \& Kim (1996) Realizaram estudos em corpos-de-prova cilíndricos, variando a resistência estática e o nível do carregamento cíclico. Notam-se que para as maiores resistências havia um decréscimo na resistência à fadiga, ou seja, para um mesmo nível de tensão em relação à resistência estática, obteve-se menor número de ciclos nos concretos de alta resistência.

Zhang \& Wu Realizaram ensaios não-destrutivos em vigas de concreto (1996) submetidas à flexão e mostraram que, além da resistência e do módulo de elasticidade, o coeficiente de Poisson também sofre redução devida ao carregamento repetido.

Hamdy (1997) Afirma que a vida do concreto à fadiga é influenciada pela magnitude e pela seqüência do carregamento, portanto a teoria de Miner não é aplicável a todos os casos. O autor propõe um modelo não-linear de dano, afirmando que esse proporciona uma análise mais realística da fadiga em estruturas de concreto.

Zhang (1998) Afirma que, em nível microscópico, ocorre uma degeneração da estrutura interna do material submetido à fadiga, e os microdefeitos se desenvolvem, tais como poros e fissuras. O concreto submetido a tensões alternadas sofre deterioração mais rápida que a tensão repetida (de um único sinal), o que é explicado pela interação das diferentes microfissuras devidas à compressão e à tração.

Crepaldi (2000) Realizou ensaios de flexão em vigas de concreto simples e com adições de fibras e de látex.

Os corpos-de-prova foram submetidos a três níveis de tensão: 65, 80 e $90 \%$ da resistência estática. Foram realizados ensaios de flexão de quatro pontos, estáticos e repetidos.

O pesquisador observou que nos corpos-de-prova de concreto simples a ruptura por flexão estática apresentava muitos agregados rompidos e alguns agregados descolados da argamassa. No ensaio de fadiga havia mais agregados descolados e alguns agregados rompidos.

Com base nos estudos apresentados, pode-se chegar às seguintes conclusões:

- Como a fadiga é um processo progressivo de microfissuração e de propagação, no concreto, pode iniciar nos microdefeitos do material, que podem crescer e provocar aumento nas tensões, até ocasionar a ruína.

- O concreto, quando submetido a ações cíclicas, sofre um processo gradual de dano por fadiga. Este processo provoca uma redução da resistência, do módulo de elasticidade e do coeficiente de Poisson do material, conforme aumenta o número de solicitações. 
- Não foi encontrado um limite de fadiga para o concreto, ou seja, não foi estabelecido uma intensidade de tensão abaixo da qual possa ser aplicado um número infinito de repetições sem que o concreto sofra fadiga. Sabe-se que com intensidade de tensão de $55 \%$ da resistência estática, chega-se a 10 milhões de ciclos.

- O carregamento cíclico provoca deformações maiores que o carregamento estático.

- Quanto maior o intervalo entre a tensão mínima e a tensão máxima, menor a resistência à fadiga.

- As tensões alternadas provocam maior dano por fadiga que as tensões repetidas (de um único sinal).

\subsubsection{FADIGA DO AÇO PARA CONCRETO ARMADO}

Os ensaios mais utilizados para determinação da resistência de barras de aço à fadiga são os ensaios axiais, com barra exposta, e os ensaios de flexão, com barra mergulhada no concreto.

Os ensaios axiais podem ser realizados com frequência alta, acima de $150 \mathrm{~Hz}$. Assim, materiais de alta resistência podem ser estudados com certa velocidade e com custo reduzido. Estes ensaios apresentam a desvantagem de difícil fixação do corpo-de-prova na máquina. Além disso, as tensões no corpo-de-prova, nas regiões de contato com as garras, podem provocar ruptura, com um número de ciclos que não representa a realidade do material.

Os ensaios de fadiga por flexão são interessantes porque simulam as condições reais das estruturas de concreto armado, mas eles apresentam a desvantagem de que a freqüência deve ser limitada, para evitar problemas de aquecimento. Normalmente uma barra é posicionada em pequenos corpos-de-prova de concreto, que são submetidos a ensaios de flexão com três pontos (viga biapoiada com força concentrada no meio do vão) ou quatro pontos (viga biapoiada com forças concentradas nos terços médios).

Os principais fatores que influenciam a resistência das barras de aço à fadiga, segundo o ACl 215R:1992, são: tensão mínima, diâmetro das barras, tipo de viga, geometria das deformações, curvatura das barras e emendas. 
Segundo o ACl 215R:1992, há indícios de que o aumento da tensão mínima reduza a resistência do aço à fadiga. Para uma mesma variação de tensão, a resistência seria menor quando a tensão mínima fosse aumentada.

A resistência à fadiga diminui com o aumento do diâmetro da barra. Isso pode ser explicado pela presença de uma maior quantidade de defeitos em uma mesma seção transversal. O efeito do diâmetro é mais pronunciado em ensaios axiais do que em ensaios de flexão. O fator dominante é a contribuição relativa da fissuração inicial e da propagação. O efeito do diâmetro da barra está relacionado com a distribuição da armadura na viga porque, quando o aço está posicionado no concreto, a partir de um determinado diâmetro, passa a ocorrer um gradiente de tensão na barra.

O tipo de deformação, de alongamento ou de encurtamento influencia a resistência das barras de aço para concreto armado porque provoca concentrações de tensão, onde a fissuração por fadiga é iniciada.

Barras curvas, em elementos de concreto, apresentam sensível redução na resistência à fadiga, se comparadas com barras retas.

Tanto as soldas entre barras paralelas como as cruzadas reduzem a resistência à fadiga do aço para concreto armado, por causa das concentrações de tensão provocadas pelos pontos de solda.

Na tabela 2.2 é apresentado um resumo da evolução histórica do estudo da fadiga no aço para concreto armado. As referências marcadas com * são citadas por Mallet (1991).

Tabela 2.2 - Evolução geral das pesquisas sobre fadiga do aço para concreto armado Autor (ano) Descrição

Wascheidt(1965)*, Verificaram que a resistência das barras lisas à fadiga é maior que Snowden (1971) e das barras nervuradas.

Healgason et al.

Pasko (1973) Realizou ensaios axiais em 60 barras normalmente utilizadas nos Estados Unidos e obteve que as barras soldadas apresentam vida útil de aproximadamente a metade em relação às barras sãs.

Jhamb \& Sugeriram, com base em resultados experimentais, que a Macgregor (1974) concentração de tensões no encontro de nervuras transversais e longitudinais é menor do que se imaginava. 
Hanson, Somes e Realizaram um trabalho experimental com vigas T, de concreto, Helagson (1974) com uma barra de aço, onde verificaram uma grande influência da variação de tensão na vida das barras de aço à fadiga. Verificaram ainda que um aumento na tensão mínima provoca uma redução na vida útil e diminui a variação de tensão que provoca a ruptura, para um número grande de ciclos. Mostraram que, em geral, o aumento da seção da barra reduz sua resistência à fadiga mas em alguns corpos-de-prova, o resultado foi diferente.

Hawkins \& $\quad$ Apresentaram resultados de ensaios em telas soldadas submetidas Heaton (1974) à fadiga. Verificaram que o comportamento à fadiga era ditado pela concentração de tensões nas interseções e não pelas alterações no material, causadas pela operação de solda. Em soldas frias, a penetração entre as duas barras é menor, portanto a resistência à fadiga é maior se comparada com as soldas quentes. Até uma penetração de $0,07 \mathrm{~cm}$, não foi observada queda na resistência. A partir desse valor, a resistência à fadiga diminuiu conforme aumentou a penetração entre as barras.

Bannister (1975)* Ensaiou vigas com barras contínuas e com barras soldadas e obteve perdas de resistência muito menores que PASKO (1973). As emendas de topo não apresentaram queda na resistência, já as emendas tipo arco tiveram a resistência reduzida em $15 \%$ em relação à barra contínua, aos 2 milhões de ciclos. Verificou-se que as soldas em barras paralelas reduzem mais a resistência em testes axiais do que em ensaios de flexão.

Barras que foram submetidas à corrosão, e posteriormente ensaiadas à fadiga, não apresentam perda de resistência, apenas perda da seção.

Bannister (1978)* Em ensaios de flexão de quatro pontos, descobriu que a ruptura por fadiga em emendas por transpasse, com comprimento inferior a 20 diâmetros da barra, não ocorre antes da ruptura da barra contínua. Já para comprimentos maiores, há uma queda na resistência à fadiga, na região da emenda.

Tilly (1979)* Revisou os conhecimentos sobre fadiga em barras de aço para concreto armado e percebeu que a maioria das pesquisas eram realizadas com tensões elevadas e com número de ciclos limitado a dez milhões. Mas grande parte dos projetos são de estruturas submetidas a tensões mais baixas, mas com vida longa, onde 0 número de ciclos é muito maior que este.

Descreveu a influência da geometria da superfície no comportamento de barras de aço à fadiga. As deformações são impostas pela aderência com o concreto, mas as mossas provocam concentrações de tensões, que reduzem a vida à fadiga.

Moss (1980)* Apresentou um programa de pesquisa sobre comportamento à fadiga do aço para concreto armado, com uma variação de tensão constante de 0,2 vezes a resistência estática e níveis de tensões que levassem a dez milhões de ciclos ou mais. 
Investigou quatro tipos de barras de aço para concreto armado, submetidas a ensaios axiais, a maioria com $16 \mathrm{~mm}$ de diâmetro e algumas com $40 \mathrm{~mm}$, para verificar o efeito da área da seção na resistência à fadiga. As barras são: tipo $A$ - encruada a frio, tipo $B$ - encruada a frio com chanfros torcidos, tipo C - laminada a quente, tipo $D$ - laminada a quente com mossas inclinadas. Foram estudadas ainda barras com corrosão superficial.

A ruptura ocorreu acima dos 97 milhões de ciclos e não foi encontrada evidência de limite de fadiga. Barras do tipo A, com $40 \mathrm{~mm}$ de diâmetro, tiveram resistências $30 \%$ inferiores que as barras do mesmo tipo com $16 \mathrm{~mm}$, aos dois milhões de ciclos.

O fator predominante no início da fissuração não foi a configuração das mossas, mas defeitos superficiais, variando de 5 $\mu \mathrm{m}$ a $100 \mu \mathrm{m}$. As barras encruadas a frio, tipos $A$ e $B$, tiveram o início da fissuração dado por múltiplas aberturas e a superfície de fratura helicoidal. As barras laminadas a quente, tipos $C$ e $D$, tenderam a formar uma única fissura inicial e superfícies de ruptura planas.

Moss investigou ainda o efeito de soldas do tipo arco de $60^{\circ} \mathrm{em}$ testes. Obteve que aos dez milhões de ciclos a perda era de $40 \%$ em relação à resistência da barra contínua.

Moss (1982)* Realizou ensaios com barras do tipo A, B e C, de $16 \mathrm{~mm}$, mergulhadas em peças de concreto com base de $12 \mathrm{~cm}$, altura de $22 \mathrm{~cm}$ e $340 \mathrm{~cm}$ de comprimento. Cada corpo-de-prova possuía uma barra longitudinal, e armadura transversal para evitar esforços secundários. Foram executados ensaios de flexão com 4 pontos e freqüência de $3 \mathrm{~Hz}$, com carregamento de amplitude constante.

Ao contrário dos ensaios axiais, o principal fator que provocou o início da fissuração foram as ranhuras ou mossas da barra.

Investigou o efeito de soldas do tipo arco de $60^{\circ} \mathrm{em}$ ensaios de flexão. A perda de resistência foi de apenas $20 \%$.

Roper (1982) Apresentou resultados de ensaios de vigas submetidas à fadiga, imersas em água do mar. Verificou que até $10^{6}$ ciclos 0 comportamento foi semelhante ao de vigas ao ar livre. A partir desse limite, houve uma queda acentuada da resistência à fadiga. Quando foi utilizado aço galvanizado, os resultados dos ensaios, dentro e fora da água do mar, foram semelhantes.

Tilly \& Moss (1982) Afirmam que a performance de barras em ensaios de flexão é melhor que nos ensaios axiais. A tensão para um determinado número de ciclos é aproximadamente $20 \%$ maior nos testes de flexão.

Bennett (1982)* Mostrou que as barras com emendas curvas provocam significativa perda de resistência à fadiga.

Booth et al. Ensaiaram vigas de concreto armado imersas em água do mar, (1986)* Utilizando ciclos em freqüências de 0,1 Hz e $3 \mathrm{~Hz}$. Os ensaios com 
$0,1 \mathrm{~Hz}$, freqüência típica das ondas do mar, produziram significativa redução do vida útil, se comparados com os testes com $3 \mathrm{~Hz}$, acima de 10 milhões de ciclos. Isso é explicado pela possibilidade do aumento da corrosão ser maior no ensaio de menor freqüência, onde o tempo de ensaio é maior.

Davies \& Austen Usando vigas com barras retas e barras curvas, concluíram que as $(1987)^{*}$ emendas com barras retas equivalem às barras contínuas, quanto ao comportamento à fadiga, mas que nas barras curvas há perda de resistência devida a concentrações de tensão.

Schläfli \& Defende que a vida do aço para concreto armado submetido à Brühwiler (1998) fadiga pode ser dividida em três fases: início de fissuração, propagação das fissuras e ruptura frágil da seção remanescente. Normalmente a fissuração começa numa nervura ou em um micro-defeito do material, que causa concentração de tensões.

Sobre o comportamento à fadiga, do aço para concreto armado, pode-se resumir:

- Na fadiga, a variação de tensão nas barras de aço é mais importante que a tensão máxima.

- Os microdefeitos, as nervuras, as soldas, a corrosão, a curvatura e as emendas reduzem a resistência à fadiga.

- Os ensaios de fadiga por tração direta fornecem resultados mais conservativos que os ensaios de flexão.

\subsubsection{FADIGA DO CONCRETO ARMADO}

O comportamento do concreto armado quando submetido à ação cíclica depende da interação do aço com o concreto. Em peças subarmadas sob flexão, a fadiga é relativa às barras de aço. Em peças superarmadas, o mecanismo de ruptura por flexão ou por cisalhamento é mais complexo.

O concreto normalmente é projetado para resistir à compressão, mas em zonas tracionadas ele é submetido a várias intensidades de tensão acima da sua resistência à tração, onde ocorrem fissuras e redistribuição das tensões para a armadura. Como o processo de fadiga depende da propagação de fissuras, a distribuição de tensões é alterada e a ruptura por fadiga não tem necessariamente o mesmo mecanismo da ruptura estática. As tensões reais na armadura raramente coincidem com as tensões calculadas usando modelos simplificados. Isto associado à variabilidade dos materiais e dos carregamentos acarretam na característica dispersiva dos resultados dos ensaios de fadiga. 
Segundo Hawkins \& Shah (1982), os aumentos na deformação e na abertura das fissuras em vigas de concreto armado submetidas a carregamento repetido são causados pela chamada fluência cíclica do concreto comprimido e pela redução da rigidez na zona de tração, por causa da fissuração e da perda de aderência entre o aço e o concreto.

Ensaios realizados por Hawkins (1974b), em lajes de concreto armado, mostraram que o comportamento à fadiga é controlado pelas características da armadura utilizada. A ruptura da primeira barra, em uma laje, pode ser estimada pelas características do aço, obtidas em ensaios individuais, aplicando processos determinísticos a fim de definir a probabilidade de ruptura. $\bigcirc$ mesmo processo fornece valores conservativos se utilizado para determinar o colapso da estrutura, assim como o modelo de Palmgreen-Miner na determinação do dano acumulado.

\section{a. Ruína por flexão}

Quando um elemento de concreto armado é submetido à flexão ocorre um gradiente de tensões na zona de compressão que fornece uma reserva de tensão para quando a fibra mais solicitada romper sob carregamento cíclico.

Em 1963, Lambotte e Baus citados por Mallett (1991), compararam vigas superarmadas com prismas carregados uniaxialmente, da mesma qualidade. A força necessário para produzir a ruína por fadiga da área comprimida das vigas foi de $70 \%$ da sua força última em ensaios estáticos. Já os prismas sob ação cíclica axial ruíram com uma força igual a $60 \%$ da sua resistência. Em 1966, Ople e Hulsbos, citados por Mallett (1991, simularam a zona de compressão utilizando carregamento excêntrico. A resistência obtida foi maior que se utilizado carregamento axial.

Schäfli \& Brühwiler (1998) apresentam resultados de ensaios de vigas de concreto armado, realizados no Instituto de Tecnologia da Suíça. Foram realizados ensaios de flexão de quatro pontos em vigas com $320 \mathrm{~cm}$ de comprimento, $15 \mathrm{~cm}$ de base e $40 \mathrm{~cm}$ de altura. As taxas de armadura eram de 0,68\%, 1,37\% e de 1,60\%. Não foi utilizada armadura transversal. Nesses ensaios foi observado dano por fadiga apenas quando o carregamento máximo ultrapassou $60 \%$ da resistência estática. A ruína ocorreu sempre por escoamento da armadura, observada pela medida dos deslocamentos, e visualmente, observando a configuração das 
fissuras e suas aberturas. As deformações e os deslocamentos aumentaram significativamente nos primeiros 100 ciclos, seguidos de um período de crescimento constante das deformações e dos deslocamentos, com uma taxa muito inferior. O aumento das deformações foi acompanhado pela propagação das fissuras: durante os 100 primeiros ciclos, a propagação das fissuras era visível na superfície. Novas fissuras se abriram, em particular na zona de cisalhamento. Na fase final dos ensaios, as fissuras normalmente mudavam de direção e se propagavam paralelas ao eixo da viga.

Schäfli \& Brühwiler (1998) observaram ainda que a distribuição das deformações acima da face inferior das vigas ensaiadas, na região de predominância de flexão, é linear, com significativo crescimento das deformações nos 100 primeiros ciclos e contínua propagação após alguns milhões de ciclos. O módulo de elasticidade do concreto submetido à fadiga diminui bastante, em função da intensidade do carregamento e do número de ciclos. A redistribuição dos esforços nas fibras mais deformadas da zona de compressão ocorre por causa dessa perda de rigidez. A distribuição das tensões na zona de compressão, que inicialmente era linear, passa a ser parabólica. Esse processo é mais pronunciado em elementos delgados submetidos à flexão, sem forças axiais (assim como lajes), por causa do elevado gradiente das tensões. Portanto, há uma grande capacidade de redistribuição dos esforços, que pode explicar porque mesmo elementos superarmados atingem a ruína por escoamento da armadura, quando submetidos a ações cíclicas.

Soretz (1974) ensaiou, com ações cíclicas, 249 vigas de concreto armado de diversas dimensões e diferentes taxas de armadura, e verificou que em todas a ruína ocorreu por escoamento e deformação excessiva da armadura principal. A fissuração foi iniciada logo nos primeiros ciclos.

\section{b. Ruína por cisalhamento}

As normas de projeto procuram garantir que o estado limite último ocorra com escoamento da armadura principal e não por ruptura brusca do concreto. Entretanto, Chang a Kesler citado por Mallett (1991), em 1958, observaram casos de fadiga por cisalhamento em vigas que, sob ação estática, ruiriam por flexão.

A fadiga em vigas sem armadura de cisalhamento foi descrita em 1983 por Frey Thürlimann citado por Mallett (1991. A fissuração se desenvolve logo depois dos 
primeiros ciclos e ocorre pouca deformação antes de aparecer a fissura crítica de cisalhamento. A ruptura resulta do desenvolvimento dessa fissura crítica, que cruza as fissuras de flexão. Em algumas vigas a armadura principal chegou a se separar do concreto. Inicialmente os deslocamentos e as deformações aumentam visivelmente, mas com o decorrer dos ciclos esse aumento é reduzido. Depois da formação da fissura crítica de cisalhamento, não é possível prever com confiança o número de ciclos até a ruína.

Ensaios realizados por Hawkins (1974a) indicaram que uma viga projetada adequadamente para ação estática, se submetida a ação cíclica, pode romper, por flexão, com $40 \%$ da carga máxima de projeto. A ruína por fadiga é acompanhada por escoamento dos estribos, com pelo menos $30 \%$ da força estática permitida pelo ACl 318-71.

Schäfli \& Brühwiler (1998) observaram, em vigas de pontes, que, quando submetidas a baixas tensões, elas romperiam apenas com um número de ciclos muito grande, a menos que essas estejam submetidas a tensões reversivas de cisalhamento. Nesse caso a resistência pode ser muito inferior, se comparada com o cisalhamento sem inversão de sinal.

\section{c. Ruptura da aderência}

Nas peças de concreto armado, com o carregamento cíclico, a resistência da aderência entre o aço e o concreto diminui. As fissuras mais abertas e a pequena contribuição do concreto na resistência à tração resultam em maiores deformações.

Caso a resistência de aderência entre o aço e o concreto seja suficiente, a ruptura ocorre ao redor da armadura, onde a tração excede a resistência do concreto. Esse tipo de fadiga é caracterizada por uma redistribuição das tensões, conforme aumenta o número de ciclos, até chegar à ruptura, quando a intensidade da tensão passa a ser constante.

Se a resistência do concreto ao fendilhamento for alta o suficiente, a ruptura ocorrerá no perímetro da barra. Este comportamento é verificado tanto na compressão quanto na tração. 
Balázs (1991) mostra a influência das ações repetidas (de um mesmo sinal) e reversos na aderência entre aço e concreto. Conclui que a hipótese de modelo linear de Miner não representa bem o problema. Verifica que as tensões alternadas produzem maiores deslizamentos que as tensões repetidas.

\section{d. Efeito da fadiga no estado de utilização}

Balaguru (1991) realizou ensaios em vigas de argamassa armada, com e sem protensão, observando que tanto as deformações quanto as aberturas das fissuras aumentam com as ações cíclicas, como já foi mostrado por outros pesquisadores. Foram utilizadas as equações apresentadas pelo ACl (1989) para determinação do módulo de elasticidade e dos deslocamentos e comparadas com resultados experimentais. Foi verificado que as constantes utilizadas nessas equações foram baseadas em um número limitado de dados e não devem ser aplicadas a vigas com um número muito grande de ciclos de carregamento.

Braguim (1995) ensaiou três vigas normalmente armadas e três superarmadas, em serviço, sob ação cíclica, e utilizou a mecânica do dano para explicar a perda de rigidez do concreto. Segundo esse autor, as normas recomendam que sejam levados em conta os efeitos da fluência na análise de estruturas de concreto armado sob cargas permanentes. O mesmo não ocorre com os efeitos análogos causados pelas forças acidentais com caráter cíclico, a chamada fluência cíclica.

Braguim realizou ensaios com ações constantes e cíclicas em vigas de concreto armado, com o objetivo de verificar a evolução dos deslocamentos. O vão adotado foi de $270 \mathrm{~cm}$. Foram projetados dois tipos de vigas: superarmadas, com $3 \phi 12,5 \mathrm{~mm}$, e normalmente armadas, com $3 \phi 8 \mathrm{~mm}$. A seção transversal adotada foi a retangular com $12 \mathrm{~cm}$ de largura e $25 \mathrm{~cm}$ de altura. Foi utilizado concreto com resistência de aproximadamente 40 MPa e aço CA-50.

Para os ensaios com carregamento cíclico, Braguim utilizou três vigas superarmadas e mais três vigas normalmente armadas. Para ensaio com força constante, foram moldadas duas vigas superarmadas e duas normalmente armadas.

Nos ensaios de fluência, a força aplicada foi igual à força máxima nas vigas com carregamento cíclico. A força foi mantida por dez dias pois, segundo o modelo 
sugerido pelo código modelo do CEB-FIP Model Code 1990 (1991b), nesse tempo seria atingida entre 75 e $80 \%$ da deformação aos dez anos.

A fim de medir os deslocamentos, foram utilizados defletômetros com sensibilidade de $0,01 \mathrm{~mm}$. Em cada viga foram posicionados dois defletômetros no meio do vão. As armaduras longitudinais e transversais foram instrumentadas com extensômetros elétricos para medida da deformação específica.

Para os ensaios com força cíclica, foi utilizado atuador com precisão de 0,1 kN. O número máximo de ciclos foi de 20000 , que equivale a cerca de $20 \%$ do total de ciclos que caracteriza uma combinação freqüente, segundo a NBR 8681:1984. A freqüência adotada foi de $1 \mathrm{~Hz}$. Assim, cada ensaio durou oito horas. As leituras, que a princípio deveriam ser realizadas aos 200, 500, 1000, 2000, 4000, 10000, 15000 e 20000 ciclos, foram acrescidas de leituras intermediárias, realizadas nos intervalos de funcionamento do atuador, necessários por causa do superaquecimento.

Para os ensaios com força permanente, a relação entre o deslocamento depois de dez dias e o deslocamento inicial variou entre 1,16 e 1,21 nas vigas superarmadas, e entre 1,24 e 1,25 nas vigas normalmente armadas. Nos ensaios com força cíclica, a relação entre o deslocamento máximo depois de 20000 ciclos e o deslocamento máximo inicial ficou entre 1,12 e 1,13 nas vigas superarmadas, e entre 1,23 e 1,28 nas vigas normalmente armadas. A relação entre 0 deslocamento mínimo aos 20000 ciclos e o deslocamento mínimo inicial foi de 1,17 nas vigas superarmadas, e variou entre 1,26 e 1,31 nas vigas normalmente armadas.

Braguim conclui que a variação dos deslocamentos nas vigas normalmente armadas sob força permanente foi da ordem de $24 \%$ do deslocamento inicial, e que nos ensaios com força cíclica o aumento do deslocamento máximo aos 20000 ciclos e deslocamento máximo inicial foi da ordem de $25 \%$. Portanto os aumentos de deslocamento são da mesma ordem de grandeza.

Nas vigas superarmadas, Braguim observou que a variação do deslocamento nos ensaios estáticos foi da ordem de 18\%, e nos ensaios de fadiga, da ordem de $12 \%$. 
Balbo (1999) define dois tipos de modelos de fadiga para os pavimentos de concreto: experimentais e semi-empíricos. Os modelos experimentais foram construídos a partir de ensaios de laboratório. Esses ensaios geralmente são realizados com freqüência elevada e sem períodos de folga. Não são levadas em conta as flutuações na tensão por causa da variação da posição da carga que ocorre nos pavimentos. Conclui-se que, de uma maneira geral, os modelos experimentais são conservativos. Os modelos semi-empíricos são definidos a partir de dados de pistas experimentais ou de pistas em funcionamento. Possuem limitações do campo de validade relativas às condições ambientais e de tráfego da região estudada.

Normalmente, as resistências dos materiais à fadiga são representadas por curvas que relacionam a intensidade de tensão (S - stress) com o número de ciclos $(N)$, chamadas de diagramas de Wöhler, traçados com base em dados experimentais.

Os principais parâmetros de fadiga para o aço são: a variação da tensão e o número de ciclos. Nas figuras 2.3, 2.4, 2.5 e 2.6 são mostradas curvas S-N relativas ao aço para concreto armado, de acordo com CEB-FIP Model Code 1990 (1991b), ACl 215R:1992, SIA 0133:1997 e NBR 6118:2003, respectivamente.

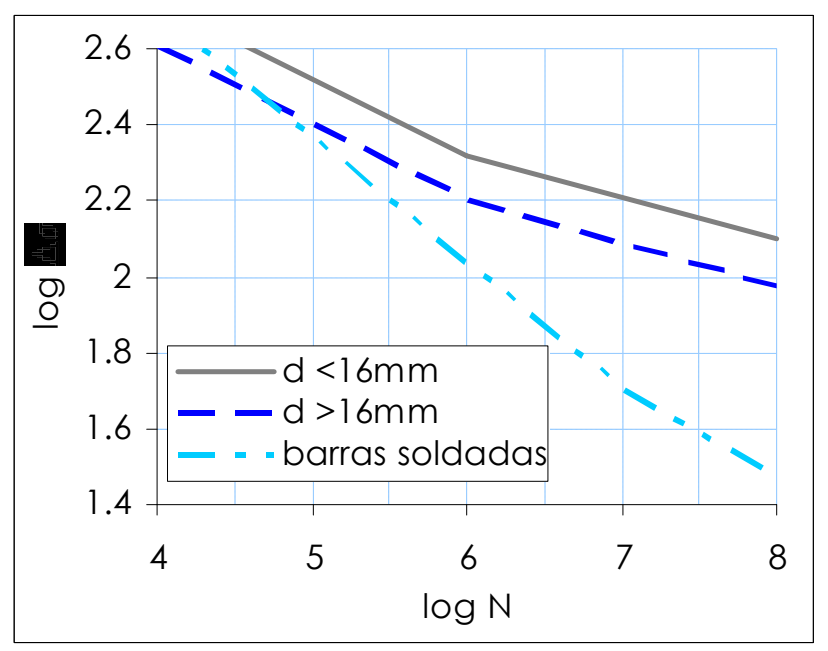

Figura 2.3 - Diagrama de Wöhler para o aço para concreto armado, a partir de valores forcecidos pelo CEB-FIP Model Code 1990 (1991) 


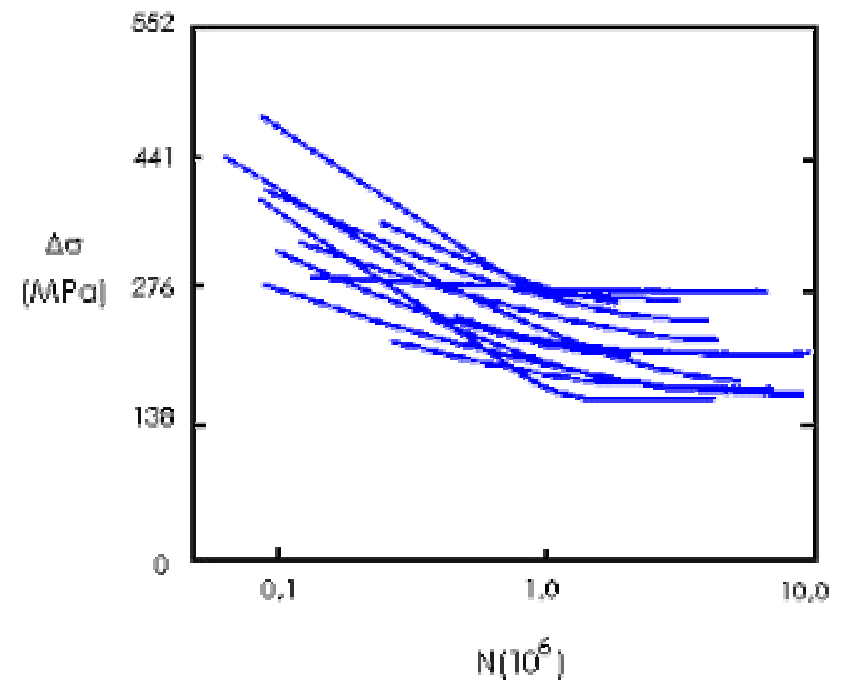

Figura 2.4 - Variação de tensão x número de ciclos, segundo ACl 215R:1992, para diferentes características das barras de aço

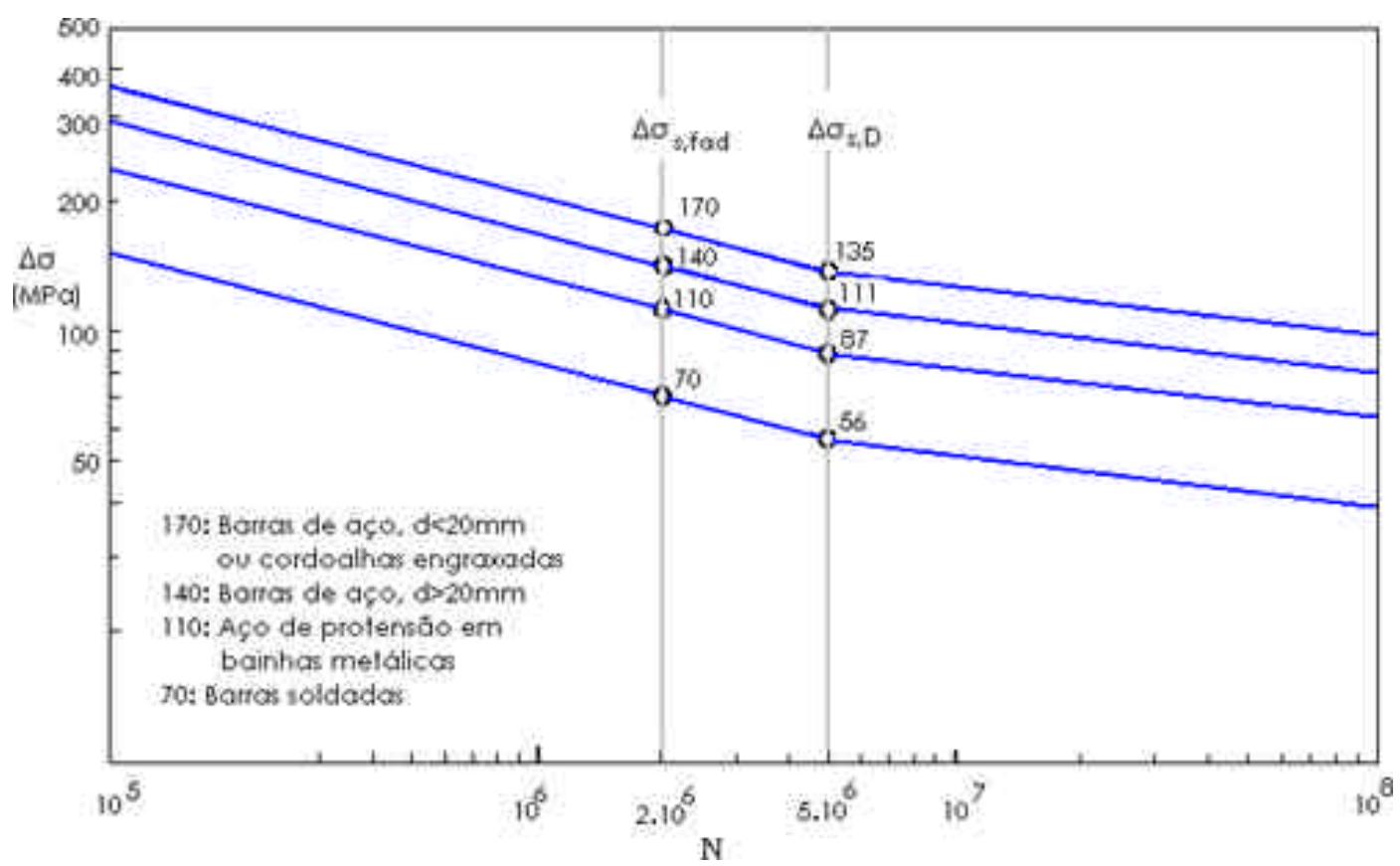

Figura 2.5 - Resistência do aço à fadiga segundo SIA 0133:1997 


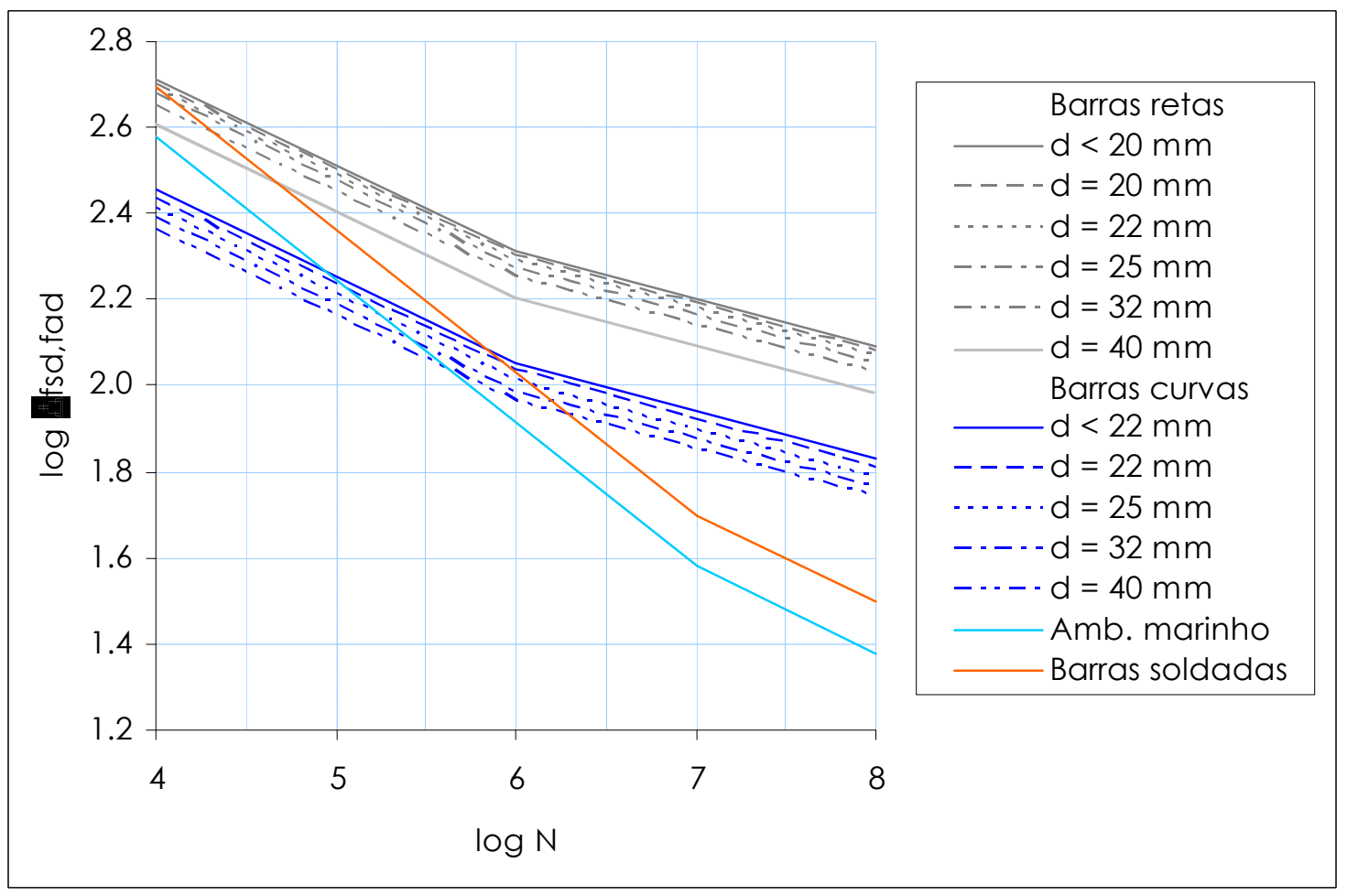

Figura 2.6 - Diagrama de Wöhler, a partir de valores forcecidos pela NBR 61 18:2003

Para o concreto são importantes as relações entre as tensões mínima e máxima com a resistência estática $\left(R_{t}\right)$, para um determinado número de ciclos. Essa relação pode ser representada pelo diagrama de Goodman, apresentado pela SIA 0133:1997, conforme é mostrado na figura 2.7. O diagrama proposto pelo ACl 215R:1992, válido para tração e compressão, está reproduzido na figura 2.8. De acordo com o CEB-FIP Model Code 1990 (1991b), o comportamento do concreto à fadiga na tração está descrito pelo gráfico da figura 2.9, traçado a partir da equação (2.2); na compressão o comportamento obedece as equações (2.4) a (2.10). A NBR 6118:2003 não apresenta valores para curva tensãodeformação para o concreto. 


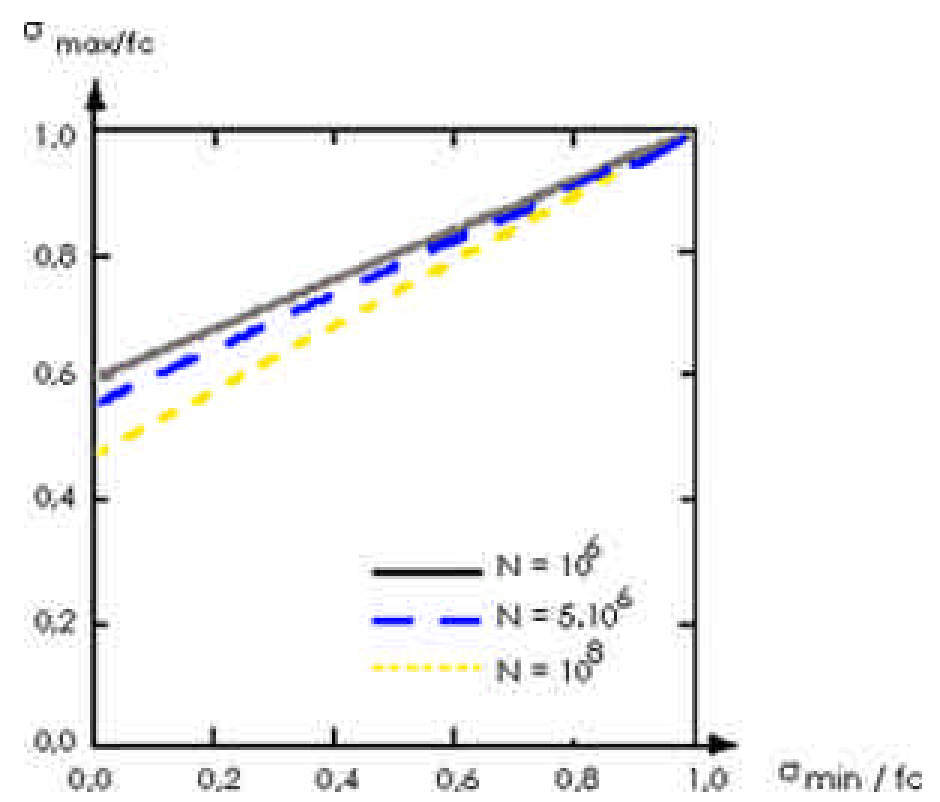

Figura 2.7 - Diagrama de Goodman para o concreto comprimido, segundo SIA-133:1997

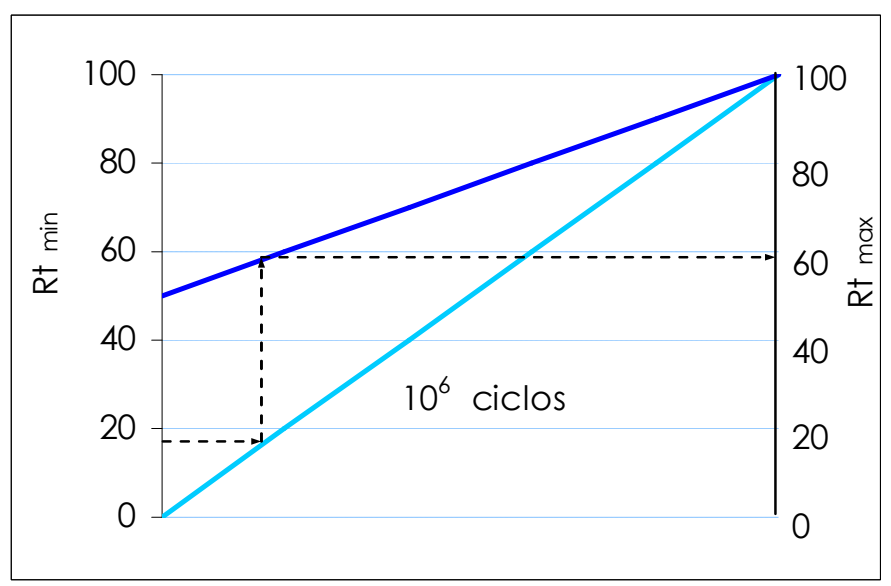

Figura 2.8 - Resistência à fadiga do concreto simples, na tração, na compressão ou na flexão, segundo ACl 215R:1992

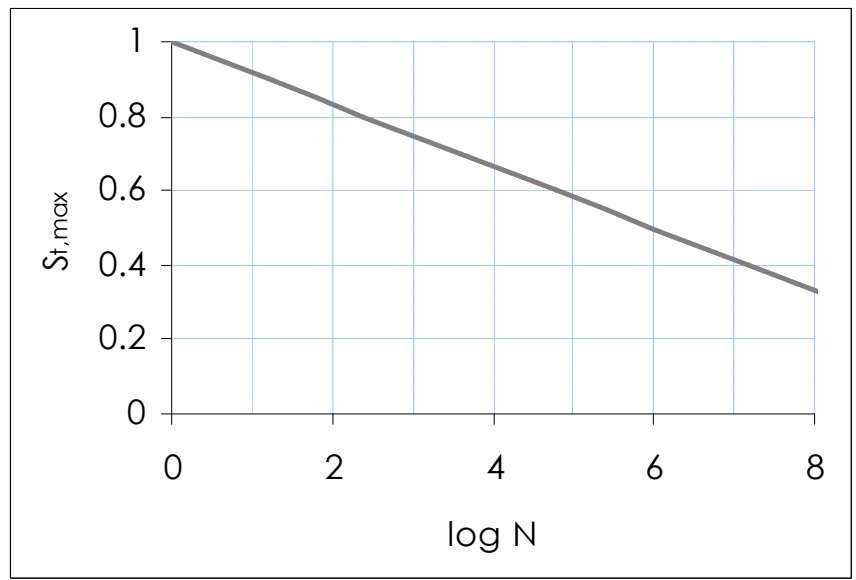

Figura 2.9 - Diagrama de Wöhler para o concreto tracionado, traçado a partir da equação (2.2), apresentada pelo CEB-FIP Model Code 1990 (1991b) 
O CEB-FIP Model Code 1990 (1991b) apresenta a seguinte equação para a resistência do concreto à fadiga:

$\log N=12 \cdot\left(1-S_{t, \text { max }}\right)$

onde:

$S_{t, \text { max }}=\frac{\gamma_{S d} \cdot \sigma_{c t, \text { max }}}{f_{c t d, f a d}}$

sendo:

- N: número admissível de solicitações;

- $\gamma_{s a}$ : igual a 1,1 segundo CEB-FIP Model Code 1990 (1991 a);

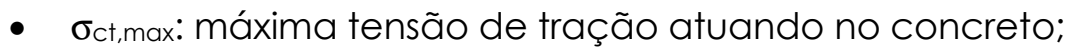

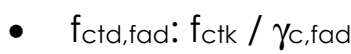

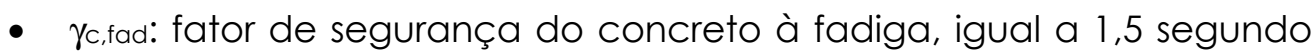
CEB-FIP Model Code 1990 (1991a).

Para o concreto comprimido, O CEB-FIP Model Code 1990 (1991b) apresenta as seguintes relações:

para $\log N \leq 6$ e $0<\mathrm{S}_{c, \min }<0,8$

$\log N=\log N_{1}=\left(12-16 \cdot S_{c, \text { min }}+8 \cdot S_{c, \text { min }}{ }^{2}\right) \cdot\left(1-S_{c, \text { max }}\right)$

para $\log N>6$ e $0<S_{c, \text { min }}<0,8$

$\log N=\log N_{2}=0,2 \cdot \log N_{1} \cdot\left(\log N_{1}-1\right)$

para $\Delta S_{c}<0,3-\frac{3}{8} \cdot S_{c, \text { min }}$ e $0<S_{c, \text { min }}<0,8$

$\log N=\log N_{3}=\log N_{2} \cdot \frac{\left(0,3-\frac{3}{8} \cdot S_{c, m i n}\right)}{\Delta S_{C}}$

onde: 


$$
\begin{aligned}
& S_{c, \text { max }}=\gamma_{s d} \cdot \sigma_{c, \text { max }} \cdot \frac{\eta_{c}}{f_{c d, f a d}} \\
& S_{c, \text { min }}=\gamma_{s d} \cdot \sigma_{c, \text { min }} \cdot \frac{\eta_{c}}{f_{c d, f a d}} \\
& \Delta S_{c}=S_{c, \text { max }}-S_{c, \text { min }} \\
& \eta_{c}=\frac{1}{1,5-0,5 \cdot\left(\frac{\left|\sigma_{c 1}\right|}{\left|\sigma_{c 2}\right|}\right)}
\end{aligned}
$$

sendo:

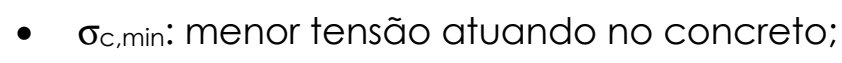

- $\sigma_{c, \text { max: }}$ maior tensão atuando no concreto;

- $f_{c d, f a d:} f_{c k} / \gamma_{c, f a d}$

- $\left|\sigma_{c l}\right|$ : menor valor, em módulo, da tensão de compressão a uma distância não maior que $300 \mathrm{~mm}$ da face, sob a combinação relevante de forças;

- $\left|\sigma_{c 2}\right|$ : maior valor, em módulo, da tensão de compressão a uma distância não maior que 300 mm da face, sob a mesma combinação relevante de força para $\left|\sigma_{c 1}\right|$.

Segundo Bull \& Salmo (1992), a primeira equação de fadiga para pavimento de concreto foi apresentada pela PCA em 1966:

$\log N=11,78-12,11 \cdot R_{\dagger}$

É assumido que a relação de tensão é superior a 50\%. Abaixo desse limite o número admissível de ciclos é considerado infinito, apesar de, nos trabalhos citados na tabela 2.1, não ter sido encontrado esse limite.

Darter (1977) apresentou a seguinte equação de fadiga de pavimentos de concreto, considerando uma probabilidade de ruptura de $50 \%$ :

$\log N=17,61-17,61 \cdot R_{\dagger}$ 
Considerando a probabilidade de ruptura de $24 \%$, a equação passa a ser:

$\log N=16,61-17,61 \cdot R_{\dagger}$

As equações (2.11) a (2.13) consideram que $R_{\dagger}$ é inferior a um. Isso ocorre nos pavimentos de concreto simples. Nos pavimentos de concreto estruturalmente armados, a relação de tensão pode ser maior que um, pois após a fissuração do concreto, os esforços são transferidos para o aço.

Em 1977, a AASHO apresentou uma equação com base na teoria das camadas elásticas, onde a tensão $\sigma$ não ficava limitada à resistência do concreto. A equação é:

$N=23440 \cdot \frac{f_{\mathrm{ct}}^{3,21}}{\sigma_{\mathrm{c \dagger}}^{3,21}}$

sendo:

- $f_{c t}$ : resistência do concreto à tração;

- $\sigma_{c t}$ tensão de tração aplicada ao concreto.

Em 1983, análises da AASHO, feitas em pistas experimentais e na teoria de placas, conduziram à equação:

$N=22209 \cdot \frac{f_{c \dagger}^{4,29}}{\sigma_{c \dagger}^{4,29}}$

Bull \& Salmo (1992), nos estudos de unidades pré-fabricadas de pavimento de concreto armado, dividem a vida à fadiga em três estágios: a) início da fissuração, b) propagação das fissuras, durante a qual há um aumento gradual da abertura dessas fissuras, seguida de c) um rápido aumento na abertura das fissuras, que leva a uma eventual fratura.

Bull \& Salmo (1992) explicam que o modelo de fadiga para pavimentos flexíveis não são aplicáveis às unidades pré-fabricadas de pavimentos de concreto armado. Para a relação entre o número de aplicações de força e a tensão do concreto, para o Estado Limite de Serviço do pavimento, apresentam a seguinte equação, desenvolvida com base em ensaios de laboratório: 
$N=225000 \cdot \frac{f_{C \dagger}^{4}}{\sigma_{c \dagger}^{4}}$

\subsection{VERIFICAÇÃO DA SEGURANÇA À FADIGA}

O CEB-FIP Model Code (1991b) apresenta três situações de verificação da fadiga, para estruturas de concreto armado. O processo simplificado pode ser aplicado a estruturas submetidas a um número limitado de ciclos (inferior a 108). Neste caso a verificação do aço pode ser feita por:

$\gamma_{S d} \cdot \max \Delta \sigma_{S t} \leq \frac{\Delta \sigma_{\text {Rsk }}}{\gamma_{s, f a d}}$

sendo:

- $\max \Delta \sigma_{\mathrm{St}}$ : máxima variação de tensão no aço;

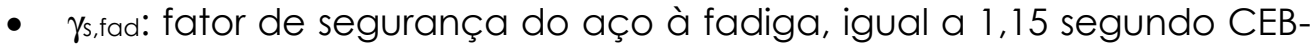
FIP Model Code 1990 (1991a).

- $\Delta \sigma_{\text {Rsk }}$ : resistência característica do aço à fadiga.

Os valores para $\Delta \sigma_{\text {Rsk }}$ são dados na tabela 2.3.

Tabela 2.3 - Resistência característica do aço à fadiga, segundo CEB-FIP Model Code 1990 (1991b)

\begin{tabular}{cccc}
\cline { 2 - 4 } & $\mathrm{N}^{*}$ & $\begin{array}{c}\Delta \sigma_{\text {Rsk }} \\
\text { para N* ciclos } \\
(\mathrm{MPa})\end{array}$ & $\begin{array}{c}\Delta \sigma_{\text {Rsk }} \\
\text { para 108 ciclos } \\
(\mathrm{MPa})\end{array}$ \\
\hline Barras com $\phi \leq 16 \mathrm{~mm}$ & $10^{6}$ & 210 & 125 \\
Barras com $\phi>16 \mathrm{~mm}$ & $10^{6}$ & 160 & 95 \\
Barras soldadas & $10^{7}$ & 50 & 30 \\
\hline
\end{tabular}

De acordo com o processo simplificado do CEB-FIP Model Code 1990 (1991b), a verificação do concreto à fadiga é feita de acordo com:

Compressão:

$\gamma_{S d} \cdot \sigma_{c, \text { max }} \cdot \eta_{c} \leq 0,45 \cdot f_{c d, f a d}$

sendo:

- $\sigma_{c, \text { max: }}$ máxima tensão de compressão no concreto; 
- $\eta_{c}$ : dado pela equação (2.10)

Tração:

$\gamma_{s d} \cdot \sigma_{c t, \text { max }} \leq 0,33 \cdot f_{c t d, f a d}$

sendo:

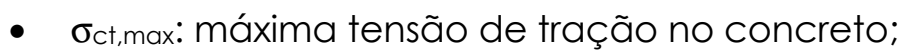

- $f_{c t d, f a d:} f_{c t k} / \gamma_{c, f a d}$

A verificação por uma única intensidade de ação equivalente, proposta pelo CEB-FIP Model Code 1990 (1991b), é um processo mais preciso que o processo simplificado. Toda ação da estrutura deve ser substituída por um número equivalente de ciclos de amplitude constante. O dimensionamento é feito considerando a vida útil, estimando o número de repetições da ação. Neste caso, a verificação da fadiga do aço é feita por:

$\gamma_{S d} \cdot \max \Delta \sigma_{S t} \leq \frac{\Delta \sigma_{R s k}(\mathrm{n})}{\gamma_{s, f a d}}$

sendo:

- $\mathrm{n}$ : número de ciclos previstos durante a vida útil da estrutura;

- $\Delta \sigma_{\text {Rsk }}(n)$ : resistência característica do aço à fadiga para n ciclos de carregamento.

Os valores de $\Delta \sigma_{\text {Rsk }}(n)$ são obtidos da curva S-N .

Para o concreto deve ser satisfeita a condição:

$\mathrm{n} \leq \mathrm{N}$

sendo:

- $\mathrm{n}$ : número solicitante de repetições;

- $\mathrm{N}$ : número admissível de repetições, determinado a partir das equações (2.4) a (2.6).

Um terceiro processo de verificação da fadiga, segundo CEB-FIP Model Code 1990 (1991b), leva em consideração a vida útil, o espectro de intensidades das ações e 
as funções de resistência à fadiga. Tanto para o concreto quanto para o aço, deve ser satisfeita a inequação:

$\mathrm{D} \leq \mathrm{D}_{\lim }$

sendo:

- D: dano causado no material por causa do processo de fadiga, calculado a partir do modelo de Palmgreen-Miner determinado pela equação (2.23);

- Dlim: dano total admitido na estrutura.

Normalmente o valor de Dlim é adotado igual a um, o que corresponderia a um dano de $100 \%$ no material.

$D=\sum_{i=1}^{j} \frac{n_{i}}{N_{i}}$

sendo:

- j: número de intensidades de carregamento;

- ni: número de solicitações de uma determinada variação de tensão i, para o aço, ou de uma certa intensidade de tensão i, para o concreto;

- $\quad N_{i}$ : número admissível de ciclos para a intensidade da solicitação i.

Segundo a NBR 61 18:2003, está satisfeita a verificação do concreto à fadiga se:

- na compressão,

$\eta_{c} \cdot \gamma_{f} \cdot \sigma_{c, \text { max }} \leq f_{c d, f a d}$

com:

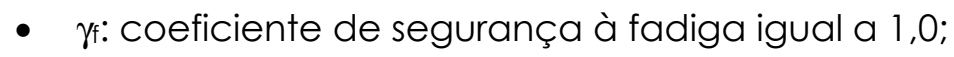

- $\mathrm{f}_{\mathrm{cd}, \mathrm{fad}}=0,45 \cdot \mathrm{f}_{\mathrm{cd}}$;

- $\eta_{\mathrm{c}}$ : dado pela equação (2.10).

De acordo com a NBR $6118: 2003, \gamma_{c}=1,4$.

- na tração, 
$\gamma_{\mathrm{f}} \cdot \sigma_{\mathrm{ct}, \mathrm{max}} \leq \mathrm{f}_{\mathrm{ctd}, \mathrm{fad}}$

sendo:

- $\quad \mathrm{f}_{\text {ctd, fad }}=0,3 \cdot \mathrm{f}_{\mathrm{ctd}, \mathrm{inf}}$

- $f_{c t d, i n f}$ é determinado por:

$\mathrm{f}_{\mathrm{ctd}, \mathrm{inf}}=\frac{\mathrm{f}_{\mathrm{ctk}, \mathrm{inf}}}{\gamma_{\mathrm{c}}}$

$f_{c t k, i n f}=0,7 \cdot\left(0,3 \cdot f_{c k}^{2 / 3}\right)$

sendo:

- $f_{c t k, i n f}$ e $f_{c k}$ : valores de resistência, em MPa.

A verificação do aço, segundo NBR 61 18:2003, é feita por:

$\gamma_{f} \cdot \Delta \sigma_{S s} \leq \Delta f_{s d, f a d}$

sendo:

- $\Delta \sigma_{S s}$ : variação de tensão no aço, proveniente da combinação freqüente do carregamento;

- $\quad \Delta \mathrm{f}_{\mathrm{sd} \text {,fad }}$ : variação de tensão admissível para $2.10^{6}$ ciclos, dada pela tabela 2.4.

Tabela 2.4 - Variação de tensão admissível, segundo NBR 6118:2003 $\Delta \mathrm{f}_{\text {sd,fad }}$, para $2.10^{6}$ ciclos, para armadura passiva, aço CA-50 (MPa)

\begin{tabular}{|c|c|c|c|c|c|c|c|c|}
\hline$\phi(\mathrm{mm})$ & 10 & 12,5 & 16 & 20 & 22 & 25 & 32 & 40 \\
\hline $\begin{array}{c}\text { Barras retas ou } \\
\text { dobradas com } \\
\qquad r \geq 25 \phi\end{array}$ & 190 & 190 & 190 & 185 & 180 & 175 & 165 & 150 \\
\hline $\begin{array}{c}\text { Barras retas ou } \\
\text { dobradas com } \\
r<25 \phi\end{array}$ & 105 & 105 & 105 & 105 & 100 & 95 & 90 & 85 \\
\hline Estribos & 85 & 85 & 85 & - & - & - & - & - \\
\hline \multicolumn{9}{|c|}{$\Delta \mathrm{f}_{\text {sd,fad }}$, para $2.10^{6}$ ciclos, para armadura ativa } \\
\hline \multicolumn{8}{|c|}{ Pré-tração, fio ou cordoalha reto } & 150 \\
\hline \multicolumn{8}{|c|}{ Pós-tração, cabos curvos } & 110 \\
\hline \multicolumn{8}{|c|}{ Cabos retos } & 150 \\
\hline \multicolumn{8}{|c|}{ Conectores mecânicos e ancoragens } & 70 \\
\hline \multicolumn{9}{|c|}{$\Delta \mathrm{f}_{\text {sd,fad }}$, para $2.10^{7}$ ciclos, para armadura passiva, aço CA-50 (MPa) } \\
\hline Ambiente marinho & 65 & 65 & 65 & 65 & 65 & 65 & 65 & 65 \\
\hline Barras soldadas & 85 & 85 & 85 & 85 & 85 & 85 & 85 & 85 \\
\hline
\end{tabular}


Os valores da tabela 2.4 admitem ensaios de tração, ao ar, com tensão máxima de $80 \%$ da tensão nominal de escoamento e freqüência de 5 a $10 \mathrm{~Hz}$.

\subsection{CONSIDERAÇÕES FINAIS}

Com os conceitos estudados verifica-se que estruturas como pisos e pavimentos, que são solicitadas por um número muito grande de ciclos de carregamento, devem sofrer o efeito da fadiga. Tanto o concreto como o aço podem romper sob tensões inferiores às suas resistências, quando sujeitos a carregamentos repetidos. O comportamento conjunto entre aço e concreto depende do tipo de estrutura. Em geral, em lajes de pequena espessura o comportamento à fadiga é dominado pela armadura.

O modelo de Palmgreen-Miner, apesar de não representar exatamente o comportamento de todas as estruturas submetidas a carregamento cíclico, pode ser adaptada com base em dados de ensaios, a fim de constituir um modelo simples de previsão da vida útil à fadiga.

As normas citadas apresentam modelos de fadiga para o concreto e para o aço. Esses modelos podem ser utilizados em análises simplificadas, onde se considera apenas uma intensidade de tensão e adota-se um número de ciclos constante, ou pode ser feita uma análise do espectro de carregamento, dentro da previsão de vida útil, e utilizar os modelos associados à proposta de dano acumulado de Palmgreen-Miner. 



\section{MODELAGEM NUMÉRICA DE PAVIMENTOS DE CONCRETO}

Westergaard (1926) é considerado pioneiro no desenvolvimento lógico de equações para determinação de tensões em placas de concreto. Por se tratar de estudo analítico, foram necessárias algumas considerações como:

- a placa de dimensões semi-infinitas é constituída de material homogêneo, isotrópico e elástico;

- as reações do subleito são verticais e proporcionais aos deslocamentos verticais da placa - Modelo de Winkler - líquido denso;

- as forças no interior e no canto da placa são distribuídas uniformemente sobre áreas circulares;

- a força na borda da placa é distribuída uniformemente sobre área semicircular.

As soluções analíticas limitam-se a poucos casos de ações e a modelos mais simples dos materiais. Portanto, a utilização de métodos numéricos possibilita a análise mais realística do comportamento dos pavimentos de concreto. A seguir serão discutidos alguns trabalhos sobre análise numérica de pavimentos rígidos e análise de estruturas de concreto armado sob carregamento cíclico.

3. 1 MODELOS DE PAVIMENTOS RÍGIDOS ENCONTRADOS NA LITERATURA

A seguir serão apresentados trabalhos nos quais foram desenvolvidos modelos numéricos para estudo de pavimentos de concreto.

\subsubsection{BULL (1991)}

Bull (1991) afirma que o procedimento desenvolvido por Westergaard não produz bons resultados para placas de $2 \mathrm{~m} \times 2 \mathrm{~m}$ (dimensão comum para unidades pré- 
fabricadas) e que os casos de carregamento atuais devem ser considerados. A substituição dos eixos múltiplos por uma única área de aplicação de força não é adequada. Propõe uma combinação da solução por múltiplas camadas elásticas com o procedimento dos elementos finitos.

Bull utilizou o programa de elementos finitos PAFEC para investigar as unidades préfabricadas, suas dimensões, a forma de carregamento e as tensões na placa e nas camadas de suporte. Foram adotados dois elementos tridimensionais, de $30 \mathrm{e}$ de 8 nós. Cada nó possui três graus de liberdade, $U_{x}, U_{y}, U_{z}$. Os parâmetros para modelagem foram obtidos de ensaios de laboratório. A geometria do modelo está apresentada na figura 3.1 e os parâmetros adotados, na tabela 3.1.

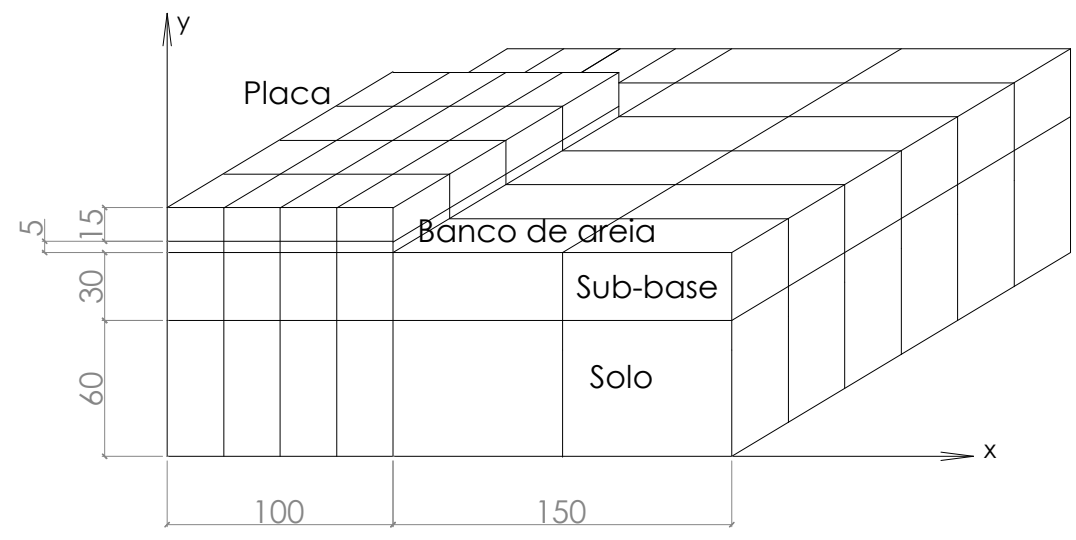

Figura 3.1 - Geometria do modelo apresentado por Bull (1991)

Tabela 3.1 - Parâmetros do pavimento estudado por Bull (1991)

Camada do pavimento

Carregamento

Placa de concreto

\section{Valores}

$10 \mathrm{kN}$, posicionados no centro

Dimensões: $2 \mathrm{~m} \times 2 \mathrm{~m} \times 15 \mathrm{~cm}$

Concreto: $50 \mathrm{MPa}$

Armadura: $3,14 \mathrm{~cm}^{2} / \mathrm{m}$ em cada direção, em cima e em baixo

Banco de areia

Espessura: $5 \mathrm{~cm}$

CBR: $7,5 \%$

Coeficiente de Poisson: 0,25

Sub-base

Espessura: $30 \mathrm{~cm}$

CBR: $20 \%$

Coeficiente de Poisson: 0,25 (drenado)

Solo

Espessura: $60 \mathrm{~cm}$

CBR: $0,3 \%$

Coeficiente de Poisson: 0,3 (drenado)

O modelo numérico inicial tinha 104 elementos, 197 nós e 458 graus de liberdade, mas modelos com mais de 1224 elementos, 2030 nós e 5285 graus de liberdade foram estudados para refinar a malha e encontrar uma curva assintótica para as tensões. A força concentrada inicial foi de $10 \mathrm{kN}$, depois foram desenvolvidas mais 
de 600 análises com diferentes disposições das rodas. Este modelo foi utilizado para desenvolver um método de dimensionamento de unidades pré-fabricadas de pavimentos de concreto, com dimensões de $2 \mathrm{~m} \times 2 \mathrm{~m}$.

\subsubsection{AL-KHALID (1991)}

Al-Khalid (1991) realizou modelagem numérica de unidades pré-fabricadas com especial referência à aplicação em pavimentos de portos. Adotou elemento tridimensional de oito nós, isoparamétrico, para representar a placa, a camada de areia, a sub-base e o solo. Cada nó do elemento possui três graus de liberdade, Ux, Uy, Uz. O programa utilizado foi o ANSYS.

Entre os parâmetros que afetam o pavimento, cita:

- as características dos materiais das diversas camadas;

- a intensidade e o número de repetições do carregamento;

- a pressão nos pneus;

- as condições do meio.

Investigações prévias com o pacote PAFEC permitem verificar:

- a posição da força que causa a tensão máxima na placa de concreto e na sub-base;

- o efeito da dimensão da placa e da posição da armadura;

- o efeito das propriedades da estrutura do pavimento.

Quanto à posição da força, as pesquisas têm demostrado que, para placas de grandes dimensões, a borda livre é mais crítica. As placas empenam as bordas para cima, o que aumenta consideravelmente as tensões no concreto. Portanto, o carregamento no canto provoca as maiores tensões de tração no concreto, na face superior. A perda de suporte também provoca aumento de tensões na face superior da placa, quando o carregamento está no canto.

Trabalhos com placas de $2 \mathrm{~m} \times 2 \mathrm{~m}$ mostram que o carregamento provoca rotação e, por consequência, aumento das tensões no solo.

A tabela 3.2 apresenta resultados de tensões no concreto em função das dimensões da placa. A análise foi realizada com uma única força de 100 kN aplicada no centro da placa. 
Tabela 3.2 - Relação tensão no concreto com as dimensões da placa, Bull \& Luheshi (1989)

\begin{tabular}{ccccccc}
\hline $\begin{array}{c}\text { Dimensões } \\
(\mathrm{m} \times \mathrm{m}) \times \\
15 \mathrm{~cm}\end{array}$ & $\begin{array}{c}\text { Área } \\
\left(\mathrm{m}^{2}\right)\end{array}$ & $\begin{array}{c}\text { Massa } \\
(\mathrm{kg})\end{array}$ & $\begin{array}{c}\text { Relação } \\
\text { entre } \\
\text { lados }\end{array}$ & $\begin{array}{c}\text { Número } \\
\text { máximo de } \\
\text { ciclos }\end{array}$ & $\begin{array}{c}\text { Tensão no } \\
\text { concreto } \\
(\%)\end{array}$ & $\begin{array}{c}\text { Tensão no } \\
\text { solo } \\
(\%)\end{array}$ \\
\hline $2,44 \times 2,44$ & 5,954 & 2143 & 1 & 291282 & 92,27 & 83,32 \\
$1,824 \times 2,44$ & 4,451 & 1602 & 1,3377 & 220727 & 97,95 & 95,42 \\
$2 \times 2$ & 4,000 & 1440 & 1 & 211158 & 100,00 & 100,00 \\
$1,22 \times 2,44$ & 2,976 & 1072 & 2 & 164981 & 106,36 & 114,95 \\
$1,3 \times 2$ & 2,600 & 936 & 1,5385 & 175233 & 104,77 & 122,08 \\
$0,916 \times 2,44$ & 2,235 & 805 & 2,6638 & 81636 & 126,82 & 130,21 \\
$0,608 \times 2,44$ & 1,484 & 534 & 4,0132 & 30283 & 162,50 & 149,54 \\
\hline
\end{tabular}

Da tabela 3.2 percebe-se que as placas maiores são mais eficientes. Porém o aumento do peso acarreta em aumento dos custos.

Quanto à armadura Al-Khalid afirma, com base em trabalhos de diversos autores, que:

- alterar seu ângulo em relação às bordas da placa altera a força de ruína;

- distribuí-la de acordo com a configuração do momento aumenta a rigidez da placa, reduz os deslocamentos, diminui a abertura das fissuras, mas tem pouca influência sobre a área de aço necessária.

O dimensionamento estrutural de um pavimento é função do número e da magnitude das forças, da pressão de contato dos pneus, das propriedades dos materiais e das condições do meio. A análise realizada por Al-Khalid tem por objetivo desenvolver gráficos de dimensionamento para unidades pré-fabricadas de pavimento, adotando veículos com 120 kN por roda e pressão de contato de 0,8 MPa. Os gráficos são desenvolvidos variando as propriedades dos materiais. $\bigcirc$ estudo paramétrico foi realizado considerando as seguintes variáveis:

- posição do carregamento;

- módulo de elasticidade do subleito;

- módulo de elasticidade e espessura da sub-base;

- espessura do concreto.

A influência do coeficiente de Poisson, da espessura e do módulo da camada de areia e da profundidade do subleito foi investigada e apresentou efeito muito pequeno. Portanto adotaram-se valores constantes para essas propriedades.

Foi adotado um modelo de referência com as seguintes propriedades: 
- Unidade pré-fabricada de concreto

- $200 \mathrm{~cm} \times 200 \mathrm{~cm} \times 15 \mathrm{~cm}$

- Resistência à compressão (corpos-de-prova cúbicos): $50 \mathrm{MPa}$

- Módulo de elasticidade: $34000 \mathrm{MPa}$

- Coeficiente de Poisson:0,15

- 25 elementos finitos

- Camada de areia

- $200 \mathrm{~cm} \times 200 \mathrm{~cm} \times 5 \mathrm{~cm}$

- Módulo de elasticidade: $75 \mathrm{MPa}$

- Coeficiente de Poisson: 0,25

- 25 elementos finitos

- Sub-base

- $500 \mathrm{~cm} \times 500 \mathrm{~cm} \times 30 \mathrm{~cm}$

- Módulo de elasticidade: 200 MPa

- CBR: $20 \%$

- Coeficiente de Poisson: 0,25

- 49 elementos finitos

- Subleito

- $500 \mathrm{~cm} \times 500 \mathrm{~cm} \times 120 \mathrm{~cm}$

- Módulo de elasticidade: 3 MPa

- Coeficiente de Poisson: 0,3

- 98 elementos finitos

Nas figuras 3.2.a a 3.2.c são mostradas as configurações dos modelos. 

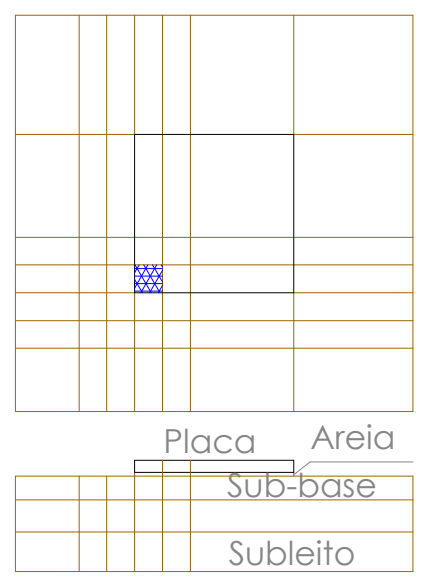

Carregamento

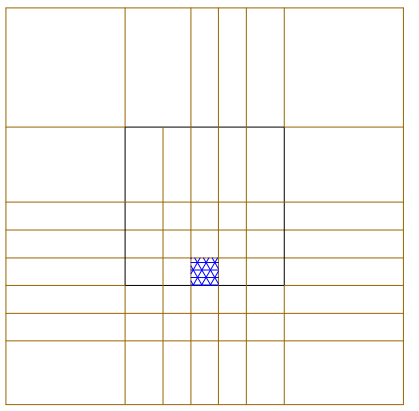

Placa Areia

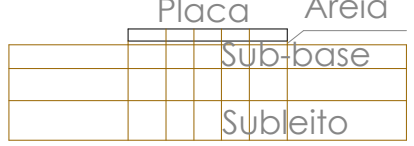

Carregamento

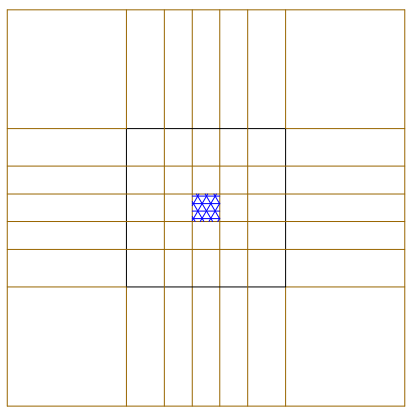

Placa Areia

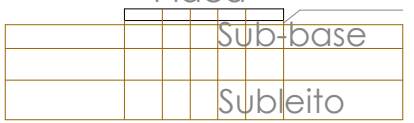

Carregamento

Figura 3.2.a-Geometria do Figura 3.2.b - Geometria do Figura 3.2.c - Geometria do modelo de Al-Khalid com modelo de Al-Khalid com força no canto da placa força na borda da placa modelo de Al-Khalid com força no centro da placa

A área de aplicação da força é quadrada, com lado de $38 \mathrm{~cm}$. O CBR do subleito variou entre $2 \%$ e $30 \%$ e, da sub-base, entre 20 e $100 \%$.

Os valores de módulo de elasticidade foram aproximados pela equação:

$\mathrm{E}=10 \cdot \mathrm{CBR}(\mathrm{MPa})$

As tensões no concreto e no subleito foram apresentadas em valor percentual em relação ao modelo de referência, para que os efeitos das variações das propriedades possam ser melhor comparados. Os resultados de tensão obtidos no modelo de referência estão apresentados na tabela 3.3.

Tabela 3.3 - Valores de tensão no modelo de referência (Al-Khalid, 1991)

\begin{tabular}{ccc}
\hline Posição do carregamento & $\begin{array}{c}\text { Máxima tensão de tração } \\
\text { no concreto (MPa) }\end{array}$ & $\begin{array}{c}\text { Máxima tensão de } \\
\text { compressão no subleito } \\
\text { (MPa) }\end{array}$ \\
\hline Centro & 1,542 & 18,75 \\
Borda & 2,278 & 55,30 \\
Canto & 1,128 & 107,00 \\
\hline
\end{tabular}

Nas figuras 3.3 a 3.6 são mostradas as variações das tensões em função das propriedades dos materiais. Nas coordenadas dos gráficos estão os valores de tensão de tração e de compressão, em porcentagem - p -, determinada por:

$P=\frac{S-S_{R}}{S_{R}}$

sendo: 
- $\sigma$ : tensão obtida;

- $\sigma_{R}$ : tensão no modelo e referência.

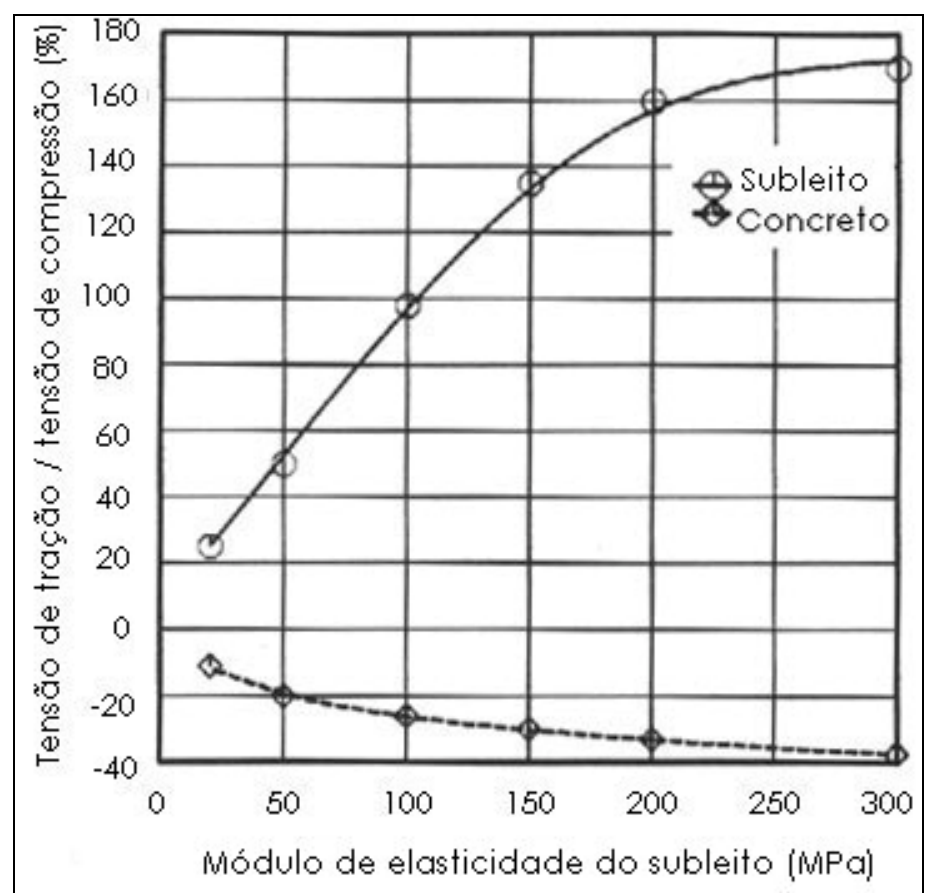

Figura 3.3 - Tensões no concreto e no subleito em função do módulo de elasticidade do subleito (Al-Khalid, 1991)

Da figura 3.3 pode-se concluir que, conforme o módulo de elasticidade do subleito aumenta, a compressão vertical no solo aumenta e a tensão de tração no concreto diminui.

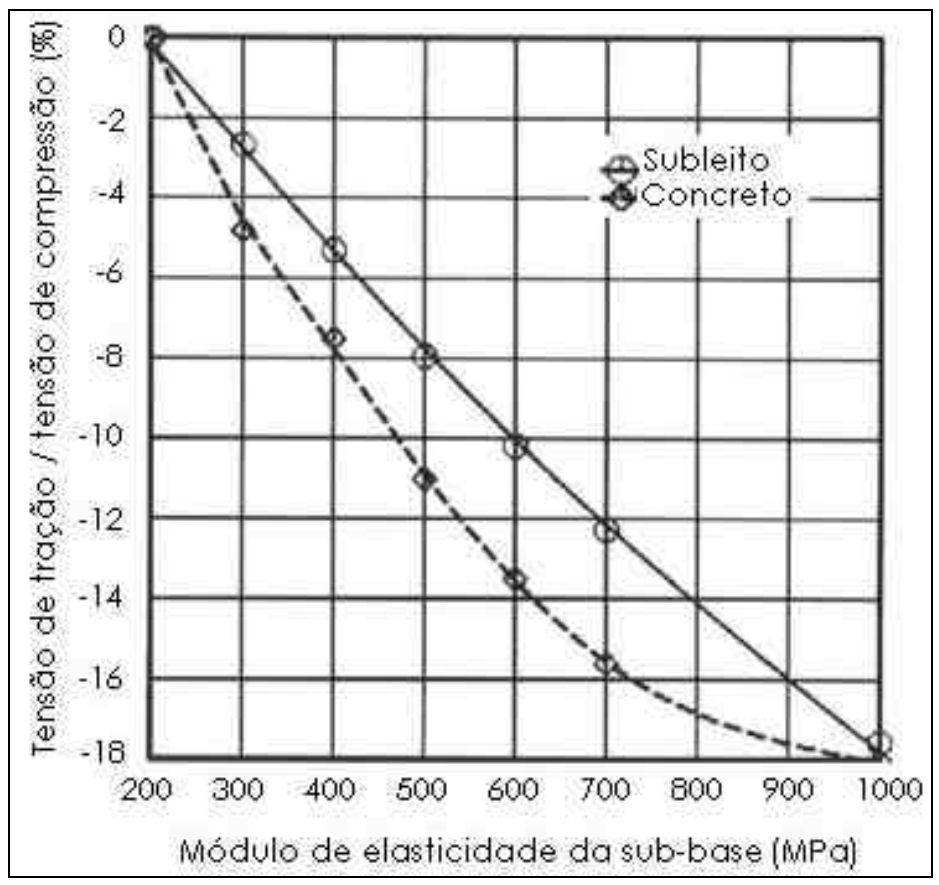

Figura 3.4 - Tensões no concreto e no subleito em função do módulo de elasticidade da sub-base (Al-Khalid, 1991) 


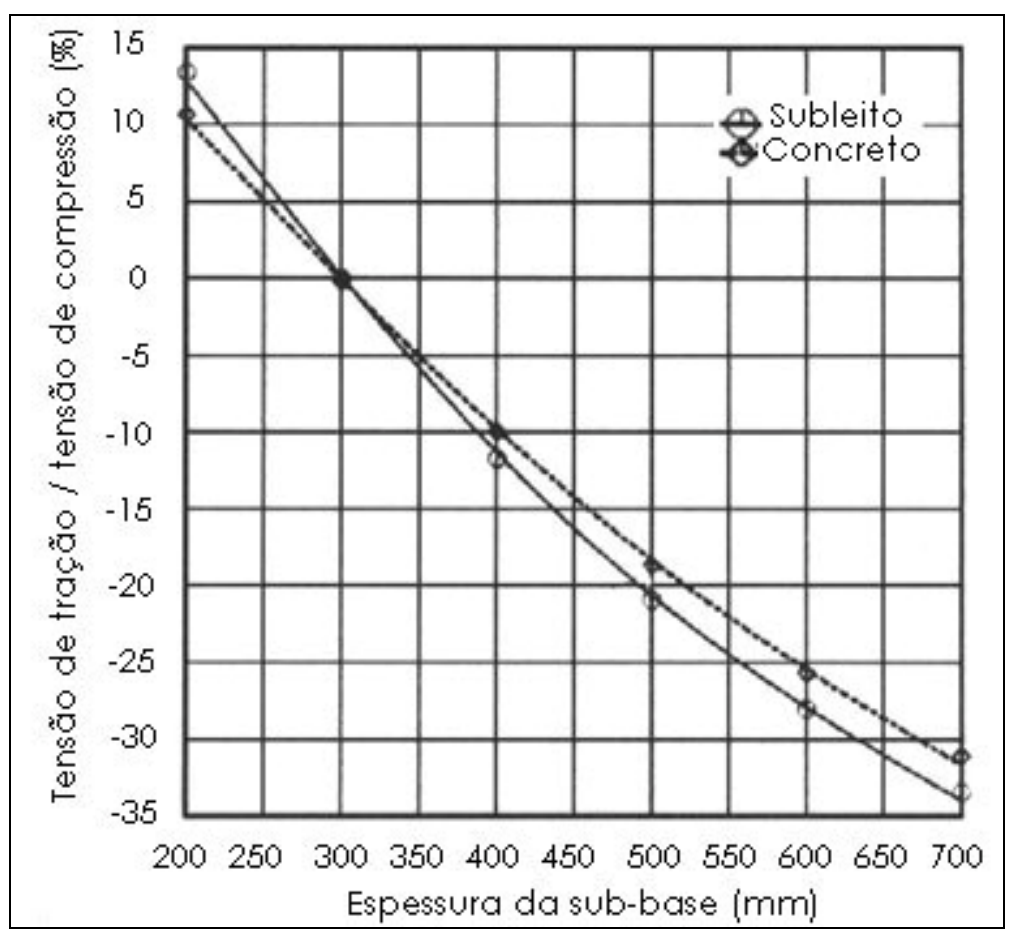

Figura 3.5 - Tensões no concreto e no subleito em função da espessura da sub-base (Al-Khalid, 1991)

Quando o módulo de elasticidade da sub-base ou a sua espessura aumenta, tanto a tensão no concreto como no subleito diminuem, como pode ser visto nas figuras 3.4 e 3.5 .

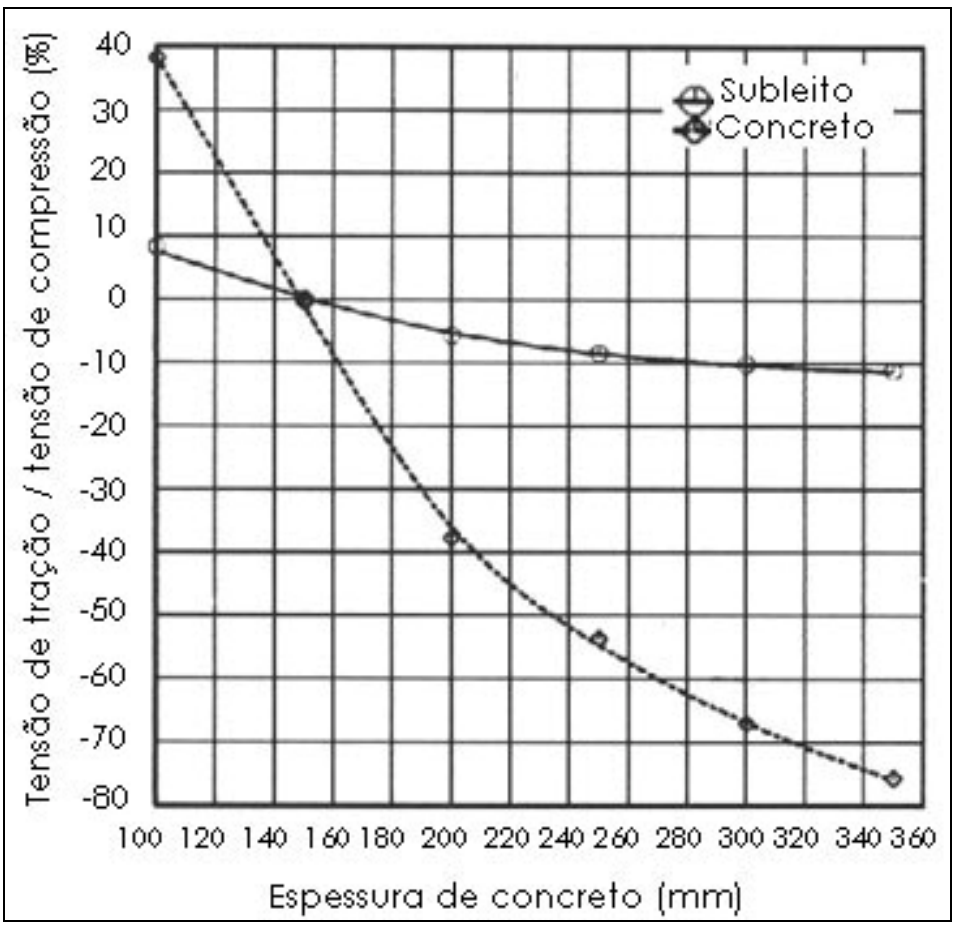

Figura 3.6 - Tensões no concreto e no subleito em função da espessura da placa de concreto (Al-Khalid, 1991) 
O aumento da espessura da placa de concreto reduz a tensão no subleito e, mais significativamente, a tensão no concreto.

Os resultados desse trabalho foram comparados com outros apresentados por Bull (1986), onde foi realizada análise semelhante, com uma única força de 10 kN, aplicada no centro da placa. A discretização e as propriedades dos materiais são semelhantes. Nas figuras 3.7 a 3.10 são mostradas as comparações entre as tensões no concreto.

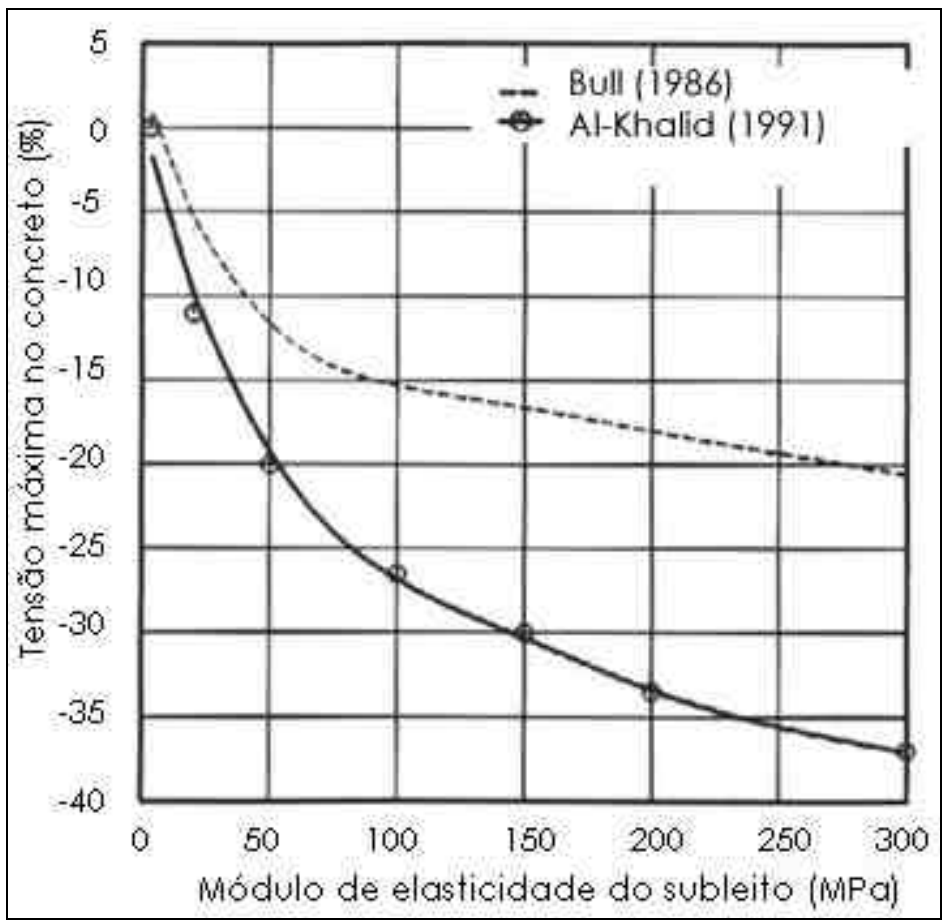

Figura 3.7 - Comparação das tensões no concreto relacionadas com o módulo de elasticidade do subleito

Nota-se que os modelos apresentam comportamentos semelhantes, mas aparece diferença significativa quando o módulo de elasticidade do subleito passa de 20 MPa para 300 MPa. No modelo de Al-Khalid, a redução de tensão no concreto é mais pronunciada. 


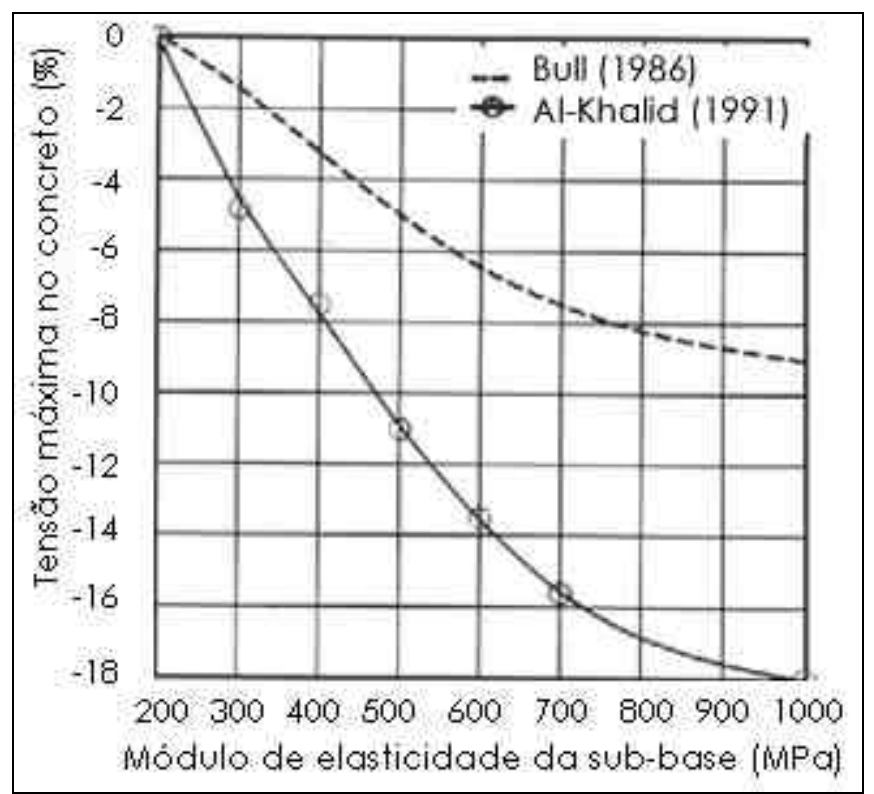

Figura 3.8 - Comparação das tensões no concreto relacionadas com o módulo de elasticidade da sub-base

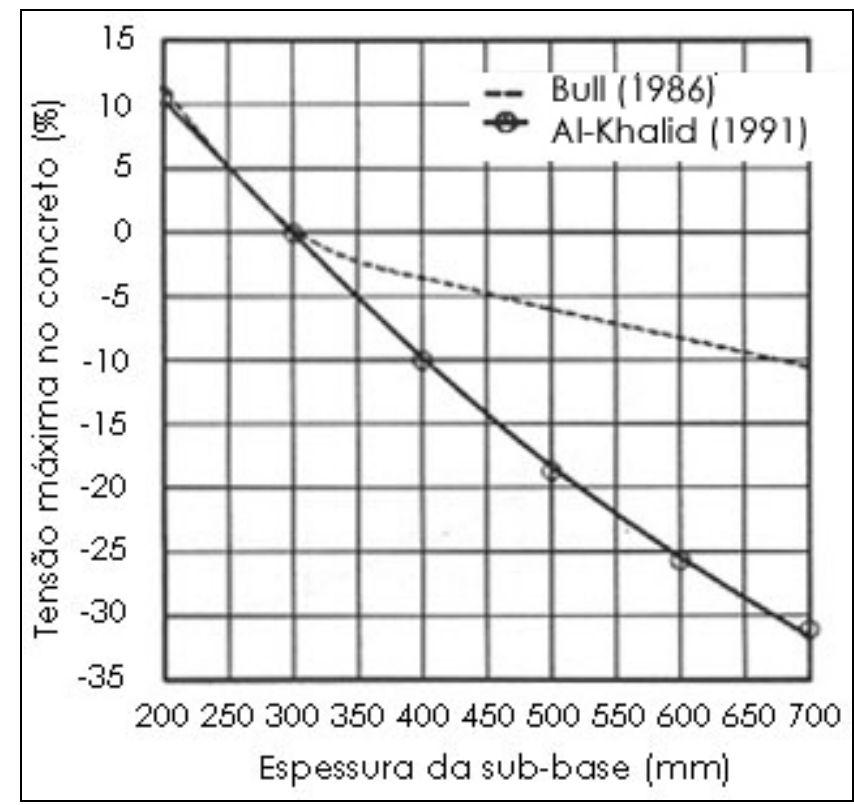

Figura 3.9 - Comparação das tensões no concreto relacionadas com a espessura da sub-base

O aumento da espessura da sub-base também provoca distanciamento entre os dois modelos. Essas diferenças se devem, segundo o autor, a diferentes posições do carregamento e a diferentes considerações das tensões de referência. 


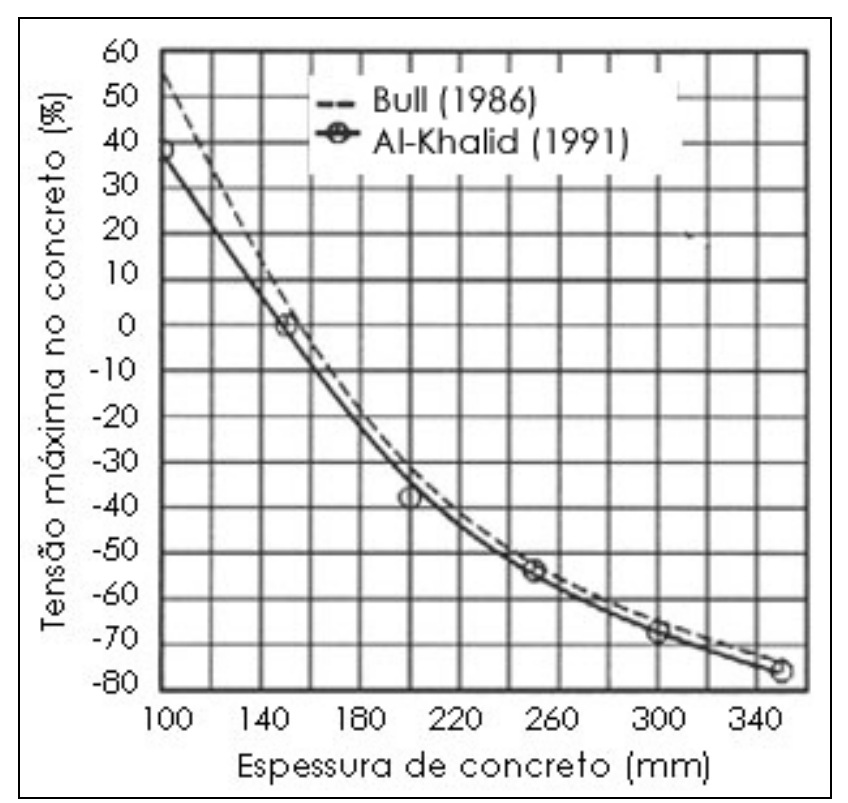

Figura 3.10 - Comparação das tensões no concreto relacionadas com a espessura da placa de concreto

Os dois modelos apresentam valores de tensão do concreto muito próximos, quando se avalia a variação da espessura da placa.

Foi possível verificar que a aplicação do carregamento distribuído em uma área semelhante à dos pneus fornece resultados melhores que a força pontual. Deve-se avaliar a posição mais crítica da força, e não apenas a situação de força centrada.

Nesse trabalho o autor utilizou análise elástica-linear, mas admite que esse não é o comportamento do concreto após fissuração. Sugere a utilização de modelos não-lineares e a verificação com pesquisas experimentais.

Foram estudadas apenas áreas de carregamento isoladas, mas deve-se avaliar também o carregamento por eixos múltiplos.

Apesar de ter realizado análise com material homogêneo, o autor indica que placas de concreto armado podem romper, por fadiga, no concreto ou no aço.

O uso de elementos finitos tridimensionais se mostrou apropriado para representar as camadas do pavimento. 


\subsubsection{BULL \& SALMO (1992)}

Bull \& Salmo (1992) utilizaram o Método dos Elementos Finitos para modelar unidades pré-fabricadas de pavimentos de concreto armado. Utilizaram elementos tridimencionais de oito nós e o programa de Elementos Finitos PAFEC (1984).

Os autores afirmam que é possível analisar numericamente as variáveis que afetam a tensão no concreto: o módulo de elasticidade, a dimensões da placa e as características elásticas da fundação.

No trabalho de Bull e Salmo não é explicado como é feita a consideração da armadura. Vale lembrar que a inércia da placa é alterada pela presença de barras de aço, e portanto a força resultante no concreto é menor, mesmo antes desse sofrer fissuração.

São apresentados os resultados de tensão no concreto em função das dimensões das placas (tabela 3.2). Verificou-se que, de uma maneira geral, maiores dimensões da placa proporcionam menores tensões no concreto.

Bull e Salmo defendem que a vida útil à fadiga dos pavimentos, mesmo das unidades pré-fabricadas que possuem armadura positiva, se refere à fissuração do concreto por tração. Portanto, para o dimensionamento, basta restringir a tensão de tração no concreto.

O comportamento à fadiga foi verificado com o auxílio de ensaios físicos em placas, descritos no capítulo 4.

\subsubsection{BULL \& WOODFORD (1997)}

Bull \& Woodford (1997) utilizaram elementos finitos tridimensionais para modelar unidades pré-fabricadas de pavimentos de concreto usadas em aeroportos. Além das placas foram modeladas também as diversas camadas do pavimento. A tensão principal máxima no concreto é calculada e utilizada para prever o estado limite de serviço, quando são necessários reparos. Essas tensões têm relação com a vida do concreto à fadiga.

O efeito do diferencial de temperatura foi desconsiderado no cálculo da tensão de tração no concreto, por se tratarem de placas relativamente pequenas, que 
se movimentam quando solicitadas, e que não possuem dispositivos de transferência de carga.

O programa utilizado na modelagem foi o PAFEC-FE. A natureza infinita da fundação foi modelada por um contorno de $3 \mathrm{~L}$ na horizontal e 2,5L na vertical, a partir do centro da placa, onde L é a medida do lado da placa. Fora desse contorno não se encontram efeitos significativos para a análise.

A modelagem por elementos finitos utilizou elementos prismáticos, tridimensionais de oito nós, isoparamétricos. Os nós ficam nos cantos do prisma e possuem três graus de liberdade cada um.

Foram escolhidos dois modelos básicos. A malha inicial utilizou 2915 nós e 2320 elementos. Posteriormente foi adotada uma malha de 5376 nós e 4448 elementos. A rigidez da fundação foi modelada restringindo os graus de liberdade dos nós do contorno. O número de graus de liberdade em cada modelo foi de 6150 e 12159 respectivamente. O tamanho dos elementos foi definido de modo a adaptá-los à superfície de carregamento, de acordo com o número de rodas considerado (dois ou quatro). Portanto, a malha não era completamente simétrica, o que não comprometeu a análise. Verificou-se que não era necessário adotar malhas mais refinadas. Foram adotados 16 casos de carregamento, representando várias posições da ação. Uma vista do modelos de 12159 graus de liberdade está mostrada figura 3.11 .

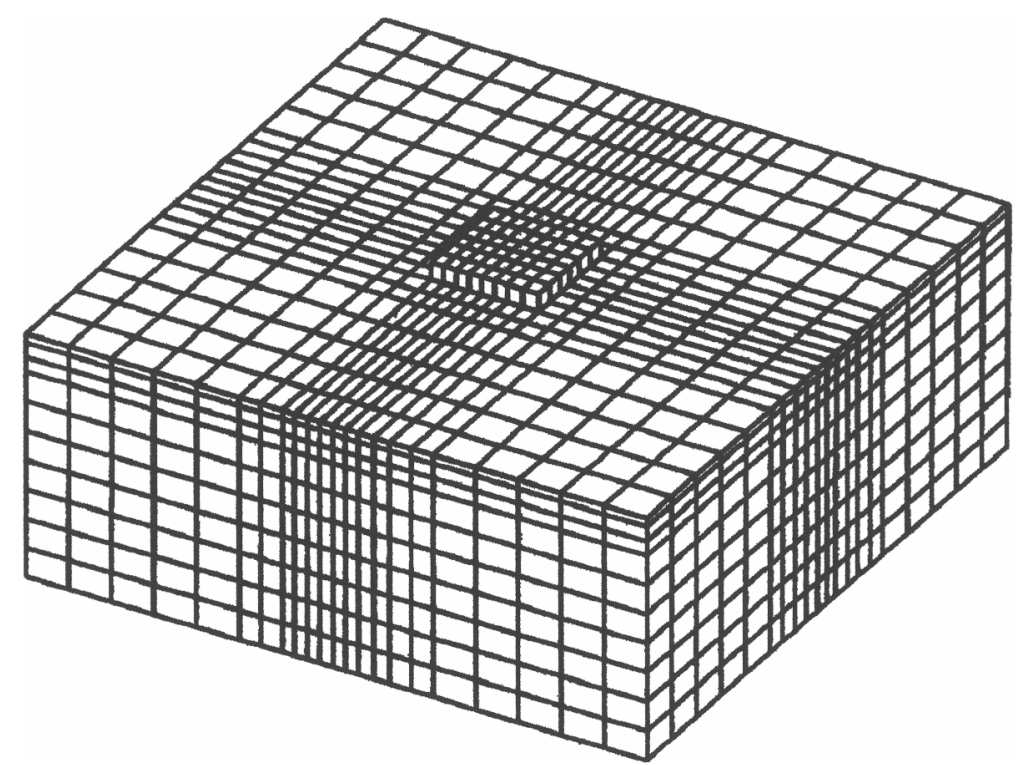

Figura 3.11 - Malha com 12159 graus de liberdade, Bull \& Woodford (1997) 
O fato das unidades pré-fabricadas não possuírem dispositivos de transferência de carga facilitou a análise numérica, pois cada placa foi considerada individualmente. Elas normalmente são posicionadas a $10 \mathrm{~mm}$ uma da outra.

As constantes do solo foram medidas no Aeroporto Internacional de Charleston. Para a resistência do concreto à compressão foi adotado um valor típico de $60 \mathrm{MPa}$, com resistência à tração na flexão de 6,8 MPa. O módulo de elasticidade foi tomado igual a $36000 \mathrm{MPa}$ e o coeficiente de Poisson, 0,15. Para a sub-base granular adotou-se módulo de elasticidade de 200 MPa e coeficiente de Poisson de 0,25 , o que representa um CBR de $20 \%$, para material com boa drenagem.

Na prática o coeficiente de Poisson muda de acordo com o grau de saturação do material, desde zero, representando um material totalmente drenado, até 0,5, representando um material totalmente saturado. Para o solo abaixo da sub-base foi adotado módulo de elasticidade de $95 \mathrm{MPa}$ e coeficiente de Poisson de 0,3, representando um nível maior de saturação.

As forças foram aplicadas nos nós, conforme esquema da figura 3.12, variando a posição de aplicação.

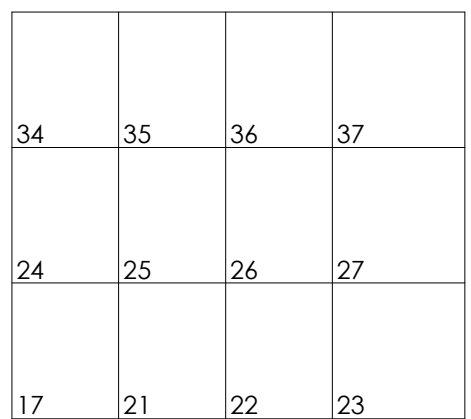

Figura 3.12 - Distribuição dos nós da placa, Bull \& Woodford (1997)

Com experiência em trabalhos anteriores, os autores optaram por um avião de $4500 \mathrm{kN}$, sendo que em cada placa pode atuar apenas $1100 \mathrm{kN}$, por causa da geometria. Para análise consideraram apropriado eixo tandem duplo. O eixo principal do trem de pouso tem comprimento de $178 \mathrm{~cm}$. Nos casos de ações de 1 a 8 , a distância entre os eixos foi igual a $132 \mathrm{~cm}$. Nos casos 9 a 12, 125,75cm, e nos casos 13 a 16, 113,5 cm. Foram adotadas essas diferenças para avaliar a sensibilidade das tensões à geometria do trem de pouso. Cada roda aplica uma força de $275,25 \mathrm{kN}$. As tensões de tração no concreto e de compressão da subbase e do subleito estão resumidas nas tabelas 3.4 e 3.5 . 
Tabela 3.4 - Tensões máximas obtidas por Bull \& Woodford (1997)

\begin{tabular}{cccccc}
\hline \multirow{2}{*}{$\begin{array}{c}\text { Caso de } \\
\text { carga }\end{array}$} & Faixa & $\begin{array}{c}\text { Posição da } \\
\text { força }\end{array}$ & $\begin{array}{c}\text { Concreto } \\
(\mathrm{mm})\end{array}$ & $\begin{array}{c}\text { Suba) } \\
\text { (MPa) }\end{array}$ & $\begin{array}{c}\text { Solo } \\
(\mathrm{kPa})\end{array}$ \\
\hline $\begin{array}{c}\text { Borda } \\
1\end{array}$ & 1320 & 17,24 & 3,771 & 351,7 & 153,3 \\
9 & 1257,5 & 17,24 & 3,929 & 359,2 & 155,4 \\
2 & 1320 & 21,25 & 1,785 & 237,8 & 108,8 \\
10 & 1257,5 & 21,25 & 1,824 & 243,3 & 110,5 \\
3 & 1320 & $17,24,22,26$ & 3,657 & 500,9 & 223,9 \\
11 & 1257,5 & $17,24,22,26$ & 3,814 & 512,4 & 227,4 \\
4 & 1320 & $25,27,21,23$ & 1,719 & 316,3 & 147,8 \\
12 & 1257,5 & $25,27,21,23$ & 1,776 & 324,8 & 150,6 \\
Centro & & & & & \\
5 & 1320 & 24,34 & 1,979 & 195,4 & 89,51 \\
13 & 1135 & 24,34 & 2,048 & 192,6 & 88,89 \\
6 & 1320 & 25,35 & 1,035 & 130,1 & 60,98 \\
14 & 1135 & 25,35 & 1,172 & 128,6 & 60,66 \\
7 & 1320 & $34,36,26,24$ & 1,943 & 264,0 & 123,5 \\
15 & 1135 & $34,36,26,24$ & 2,210 & 260,5 & 122,7 \\
8 & 1320 & $35,37,27,25$ & 1,245 & 143,8 & 70,19 \\
16 & 1135 & $35,37,27,25$ & 1,455 & 142,0 & 69,78 \\
\hline
\end{tabular}

Tabela 3.5 - Deslocamentos máximos obtidos por Bull \& Woodford (1997)

\begin{tabular}{ccccccc}
\hline \multirow{2}{*}{$\begin{array}{c}\text { Caso de } \\
\text { carga }\end{array}$} & $\begin{array}{c}\text { Para baixo } \\
(\mathrm{mm})\end{array}$ & $\begin{array}{c}\text { Para cima } \\
(\mathrm{mm})\end{array}$ & $\begin{array}{c}\text { Caso de } \\
\text { carga }\end{array}$ & $\begin{array}{c}\text { Para baixo } \\
(\mathrm{mm})\end{array}$ & $\begin{array}{c}\text { Para cima } \\
(\mathrm{mm})\end{array}$ \\
\hline $\begin{array}{ccccccc}\text { Borda } \\
1\end{array}$ & 2,589 & 0,4739 & & 9 & 2,628 & 0,4885 \\
2 & 1,885 & 0,1644 & 10 & 1,914 & 0,1814 \\
3 & 3,910 & 0,3307 & 11 & 3,972 & 0,3652 \\
4 & 2,818 & nulo & 12 & 2,868 & nulo \\
Centro & & & & & & \\
5 & 1,789 & 0,0903 & 13 & 1,805 & 0,0911 \\
6 & 1,263 & nulo & 14 & 1,270 & nulo \\
7 & 2,585 & nulo & 15 & 2,605 & nulo \\
8 & 1,661 & nulo & 16 & 1,672 & nulo \\
\hline
\end{tabular}

As máximas tensões verticais na sub-base e no solo foram registradas na superfície superior de cada uma. Na placa, dependendo da configuração do eixo, a tensão máxima pode ocorrer na face inferior ou na face superior, entre duas linhas de rodas.

Na tabela 3.4, é possível notar que, para ações na borda, casos 1 a 4 e 9 a 12, a redução da distância entre eixos de $132 \mathrm{~cm}$ para 125,75 cm causou um acréscimo na tensão de $4,3 \%$ no concreto, $2,7 \%$ na sub-base, e $1,9 \%$ no solo. Para carregamento de centro, casos 5 a 8 e 13 a 16, a redução de $132 \mathrm{~cm}$ para $113,5 \mathrm{~cm}$ aumentou a tensão no concreto em 16,9\%. Neste caso as tensões na sub-base e no solo caíram $1,4 \%$ e $0,7 \%$ respectivamente. A maior tensão no 
concreto aconteceu quando uma roda está posicionada no canto da placa e a outra posiciona-se na borda.

A consideração da fadiga foi feita utilizando a equação (2.16). Essa equação foi desenvolvida com base em ensaios de laboratório realizados com placas de $2 \mathrm{mx}$ $2 \mathrm{~m}$, mas os autores consideraram razoável a extrapolação para placas de 3,775 m. Para a verificação do processo de deformação plástica no solo, foi adotada a equação:

$\mathrm{N}_{\text {solo }}=\left[\frac{(280 \cdot \mathrm{CBR})}{\sigma_{\text {solo }}}\right]^{4}$

sendo:

- Nsolo: número de carregamentos admitido pelo solo;

- $\sigma_{\text {solo: }}$ tensão aplicada no solo.

\subsubsection{BULL \& WOODFORD (1998)}

Bull \& Woodford (1998) desenvolvem análise numérica semelhante à do item 3.1.4, mas desta vez são estudadas unidades pré-fabricadas com colar de aço. Esse colar pode ser uma solução quando o movimento de veículos nas bordas provoca grande aumento de tensão no concreto e bombeamento do material de suporte. O colar de aço é uma proposta para desenvolvimento de dispositivo de transferência de carga que não exija trabalhos de obra além do posicionamento das placas. Nesse trabalho os autores verificaram a influência do colar nas placas de concreto. A geometria das placas estudadas está mostrada na figura 3.13.

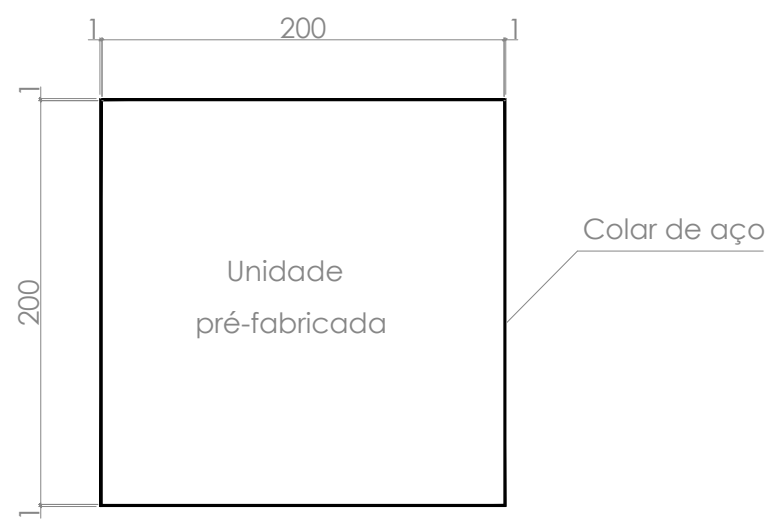

Figura 3.13 - Geometria das unidades pré-fabricadas com colar de aço (Bull\&Woodford, 1998) 
Justificando que não há evidências suficientes de que modelos não-lineares do solo obtenham resultados melhores que os modelos elásticos, os autores adotaram o sólido elástico de Boussinesq. Para modelar o espaço semi-infinito pelo método dos elementos finitos, adotou-se uma região de grandes dimensões, na qual o contorno recebe esforços insignificantes.

É realizada análise tridimensional das camadas do pavimento, utilizando elementos finitos. Primeiramente é assumido que não há separação entre as camadas e que os materiais são elástico-lineares, tanto na tração quanto na compressão. Na prática, os efeitos das fissuras no concreto e de pequenos esforços de tração nas camadas inferiores do pavimento, assim como a separação entre a placa e a sub-base, deveriam ser considerados. Os dois primeiros estão embutidos na equação de fadiga.

É possível analisar a separação da placa de concreto da sub-base. Neste modelo é introduzido contato entre essas duas camadas. Comparando os dois modelos verificou-se que o segundo:

- Para carregamento no centro:

- o coeficiente de atrito provocou aumento nos deslocamentos verticais e no movimento horizontal;

- a pressão na fundação reduziu, com exceção das bordas, onde aumentou a tensão.

- Para carregamento no canto:

- aumentou o levantamento dos cantos;

- aumentou o deslocamento vertical da placa;

- aumentaram as tensões nas camadas de fundação;

- diminuiu a tensão no concreto.

- Para carregamento na borda:

- aumentou o levantamento dos cantos;

- aumentou o deslocamento vertical da placa;

- aumentou a tensão no concreto;

- aumentaram as tensões nas camadas de fundação; 
Resumindo, o modelo com contato entre a placa de concreto e a sub-base indica uma vida útil menor para o pavimento e mostra que a separação entre as camadas tem efeito mais significativo do que era acreditado. Nesse trabalho é adotado modelo com compatibilidade de deslocamento entre os nós. Os resultados podem ser relacionados com o modelo que permite descolamento da placa, visto que Bull (1991b) investiga, quantifica e relaciona os dois.

Nesse trabalho o contorno da massa de solo foi traçado a 2,5 m do centro da placa, na horizontal, e $0,97 \mathrm{~m}$, na vertical. O aumento do contorno não modifica significativamente os resultados.

Da mesma forma que no trabalho anterior, foi utilizado elemento tridimencional, com oito nós e três graus de liberdade por nó do programa PAFEC-FE para modelar as placas com $2 \times 2 \mathrm{~m}$. O colar de aço, com $1 \mathrm{~cm}$ de espessura, foi modelado com elemento curvilíneo quadrilátero isoparamétrico de quatro nós. Este elemento recebe carregamento apenas no seu plano e a tensão não varia na espessura. É um elemento normalmente usado para estruturas finas sem tensões normais à superfície e com efeitos de flexão desprezíveis. O elemento tem dois graus de liberdade por nó, os deslocamentos no seu próprio plano, e, depois da translação, passa a permitir deslocamentos nas três direções.

Os modelos com colar ficaram com 993 elementos, 1632 nós e 3868 graus de liberdade. Sem o colar ficaram com 944 elementos, 1550 nós e 3698 graus de liberdade.

Foram estudados 27 casos de carregamento, nas posições indicadas na figura 3.14, para uma roda, e na figura 3.15, para duas.

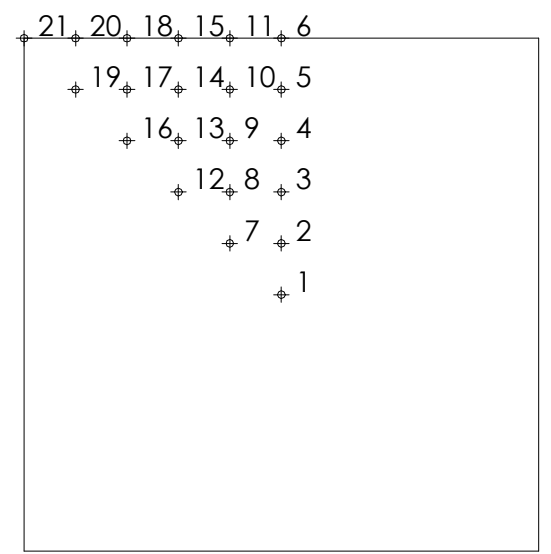

Figura 3.14 - Posição das forças, Bull \& Woodford (1998)

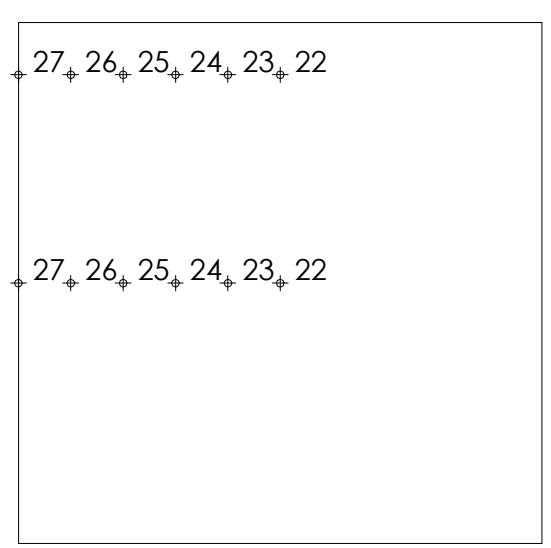

Figura 3.15 - Posição dos eixos, Bull \& Woodford (1998) 
Nesse trabalho as forças de 10 kN, cada uma, são aplicadas nos nós. Pesquisas anteriores mostraram que, para ação constante, o aumento da área de aplicação das forças implica em redução dos deslocamentos, das tensões no concreto a na fundação. Porém é possível relacionar as tensões oriundas de ações nodais com as de qualquer área de aplicação e força.

As propriedades dos materiais adotadas nesse trabalho correspondem àquelas encontradas em obras de pavimentação e no laboratório de ensaios da Universidade de Newcastle. Foi usado um concreto de resistência à compressão de $55 \mathrm{MPa}$, com módulo de ruptura de 6,6 MPa. As propriedades da camada de areia, da sub-base e do solo representam materiais com boa drenagem, valores de CBR de $7,5 \%, 51,12 \%$ e 2,5\%, respectivamente.

Novamente, para determinar a vida útil, foram utilizadas as equações (2.16) e (3.31).

Para ação de apenas uma roda, a posição 21 apresentou o maior deslocamento vertical, a maior tensão de tração no concreto e a maior tensão na face superior da placa. O segundo maior esforço gerado por uma roda foi obtido na posição 6.

O efeito da colocação do colar de aço para as posições 1 a 4, 7 a 9, 12, 13 e 16 é mínimo. Para as posições 5, 10, 14, 17 e 19 o efeito é significativo. Para as posições 17 e 19 o aumento do número de ciclos cresce $96 \%$ e $59,1 \%$, respectivamente.

Os autores apresentam os resultados de tensão máxima no concreto mostrados na tabela 3.6.

Tabela 3.6 - Tensões de tração máximas no concreto, obtidas por Bull \& Woodford

\begin{tabular}{ccc}
\hline Posição & $\begin{array}{c}\text { Tensão no concreto para } \\
\text { placa sem colar de aço } \\
(\text { MPa) }\end{array}$ & $\begin{array}{c}\text { Tensão no concreto para } \\
\text { placa com colar de aço } \\
(\mathrm{MPa})\end{array}$ \\
\hline 6 & 0,7367 & 0,6436 \\
11 & 0,7358 & 0,6418 \\
15 & 0,7279 & 0,6299 \\
16 & 0,3393 & 0,3351 \\
18 & 0,6925 & 0,5794 \\
20 & 0,3293 & 0,2932 \\
21 & 0,7078 & 0,4953 \\
24 & 1,432 & 0,9151 \\
25 & 0,4964 & 0,4183 \\
26 & 0,4408 & 0,3644 \\
27 & 0,3796 & 0,3379 \\
& 0,7018 & 0,5192 \\
\hline
\end{tabular}


O ganho na vida útil do pavimento com a colocação do colar, visando a análise com eixo duplo, foi de 1,39 milhões de ciclos.

\section{1.6 PALIGA \& REAL (2003)}

Buscando estudar o comportamento de pavimentos portuários, em laje de concreto armado, submetidos a carregamento de grande intensidade, Paliga \& Real (2003) desenvolveram um programa empregando o método dos elementos finitos, onde o concreto é modelado por meio de elementos isoparamétricos quadráticos de oito nós. O modelo constitutivo do concreto é bidimensional, e inclui o comportamento não-linear do material e a fissuração. São adotados os diagramas tensão-deformação apresentados pelo CEB-FIP-1990 (1991). Após a fissuração, para incluir a colaboração do concreto entre fissuras na resistência à tração, é adotado um ramo descendente na curva tensão-deformação. A armadura é considerada como uma camada mais rígida dentro do elemento de concreto, que apenas resiste a esforços axiais na direção das barras. O solo é modelado como elastoplástico e oferece reação apenas aos esforços de compressão. O modelo adotado para o solo é de líquido denso (Winkler), onde molas são distribuídas continuamente ao longo da superfície do elemento e as pressões de contato são proporcionais aos recalques até se atingir a tensão de plastificação do solo.

Os autores apresentam um exemplo de laje portuária com 25,75 m x 9,00 m e $25 \mathrm{~cm}$ de espessura, onde deverá operar um guindaste de $3500 \mathrm{kN}$, distribuídos em seis eixos, com quatro rodas por eixo. Foi adotada armadura superior com $4,17 \mathrm{~cm}^{2} / \mathrm{m}$ e inferior com $7,81 \mathrm{~cm}^{2} / \mathrm{m}$. Para a análise numérica foi usada simetria, modelando apenas $1 / 4$ da placa. Para tanto, foram gerados 176 elementos e 583 nós.

Para a modelagem foram adotadas as seguintes características para os materiais:

- Concreto:

- $\mathrm{E}=3355 \mathrm{kN} / \mathrm{cm}^{2}$

- $v=0,20$

- $\mathrm{f}_{\mathrm{c}}=3,80 \mathrm{kN} / \mathrm{cm}^{2}$

- $\mathrm{f}_{\mathrm{ct}}=0,29 \mathrm{kN} / \mathrm{cm}^{2}$ 
- Aço:

- $\mathrm{E}_{1}=21000 \mathrm{kN} / \mathrm{cm}^{2}$

- $\mathrm{E}_{2}=0$

- $\mathrm{f}_{\mathrm{y}}=54,48 \mathrm{kN} / \mathrm{cm}^{2}$

- Solo:

- Areia compactada: $4,6 \cdot 10^{-2} \mathrm{kN} / \mathrm{cm}^{3}$

- Solo estabilizado: $\mathrm{k}=14,9.10^{-2} \mathrm{kN} / \mathrm{cm}^{3}$

- Areia de média compacidade: $\mathrm{k}=1,75 \cdot 10^{-2} \mathrm{kN} / \mathrm{cm}^{3}$

Além dos carregamentos das rodas do guindaste foi considerado um peso próprio de $6,25 \cdot 10^{-4} \mathrm{kN} / \mathrm{cm}^{2}$ e um carregamento acidental de $50.10^{-4} \mathrm{kN} / \mathrm{cm}^{2}$.

Na figura 3.16 são apresentados os momentos fletores para o carregamento de serviço, no caso e placa sobre solo estabilizado.

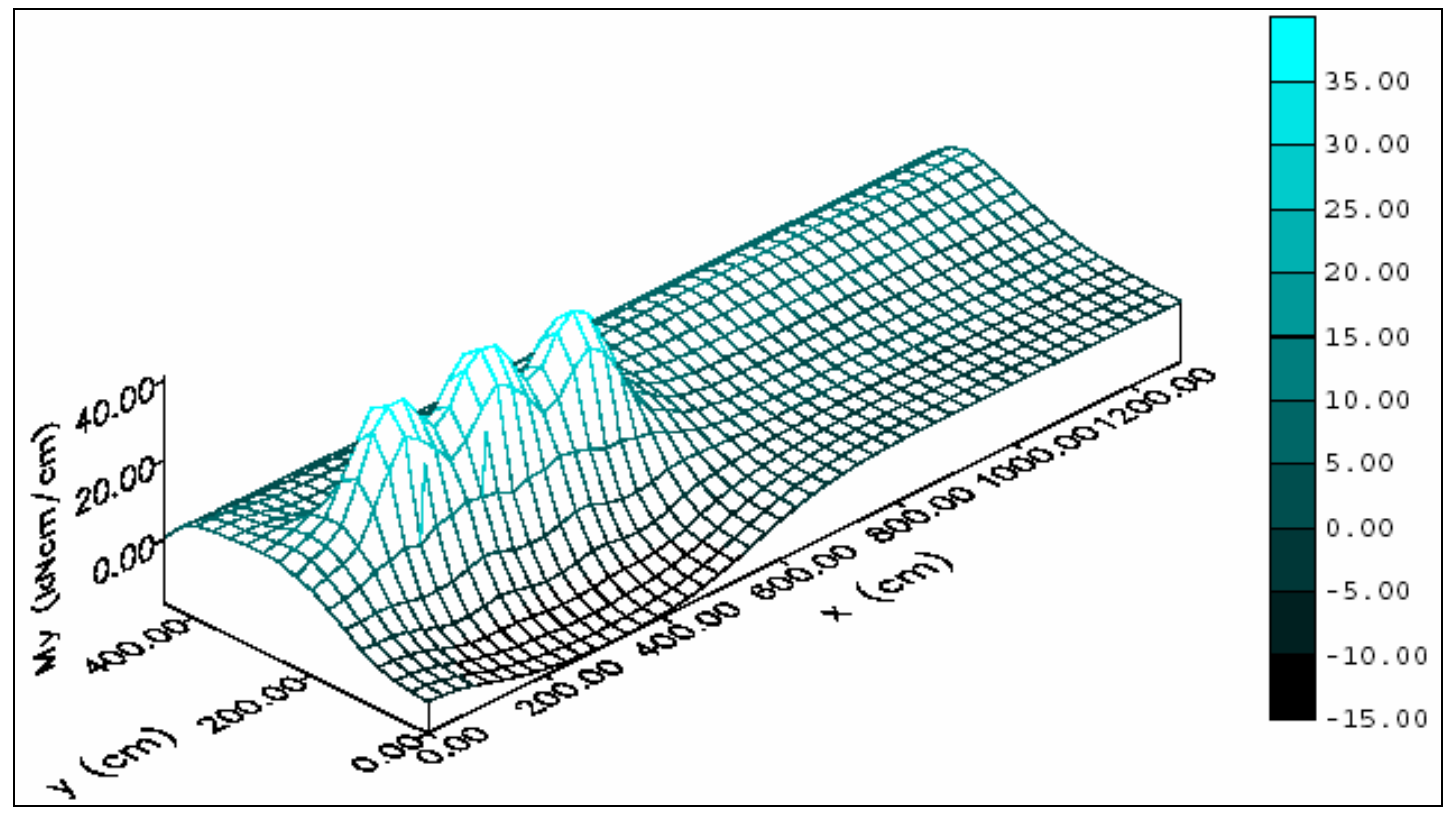

Figura 3.16 - Distribuição dos momentos fletores My obtida por Paliga \& Real (2003)

Uma comparação entre os deslocamentos para os três tipos de fundação está apresentada na figura 3.17. 


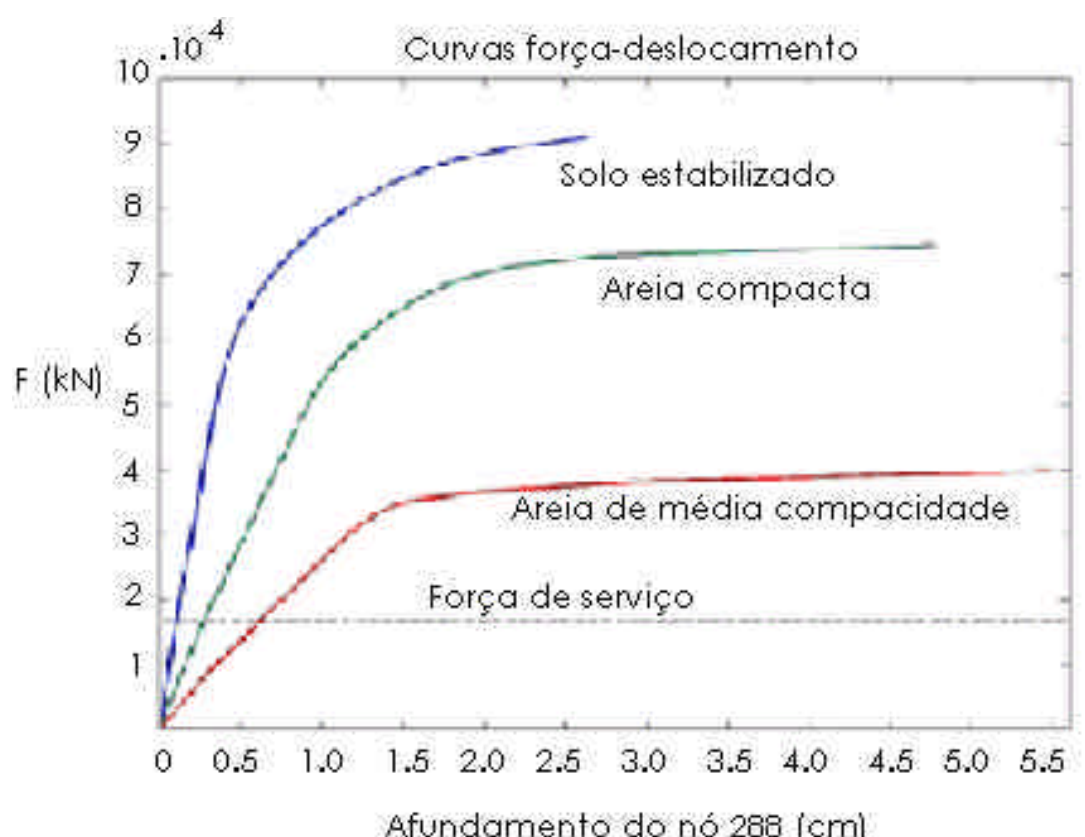

Figura 3.17 - Força-deslocamento para diferentes tipos de solo (Paliga \& Real-2003)

Nas três análises a ruptura ocorreu por deformação plástica excessiva da armadura, na direção y, próximo aos pontos de momento fletor máximo.

Também foram realizadas análises variando a espessura da placa. Neste caso, os esforços foram recalculados em uma análise elástica-linear, e as armaduras redimensionadas para cada caso. Os demais dados foram mantidos constantes e foi adotado o solo estabilizado.

A figura 3.18 mostra os deslocamentos em função da força, para diferentes espessuras da placa. Outra análise considerou diferentes resistências do concreto. Os resultados estão apresentados na figura 3.19. Foi variada ainda a taxa de armadura da laje. Os resultados estão apresentados na figura 3.20. 


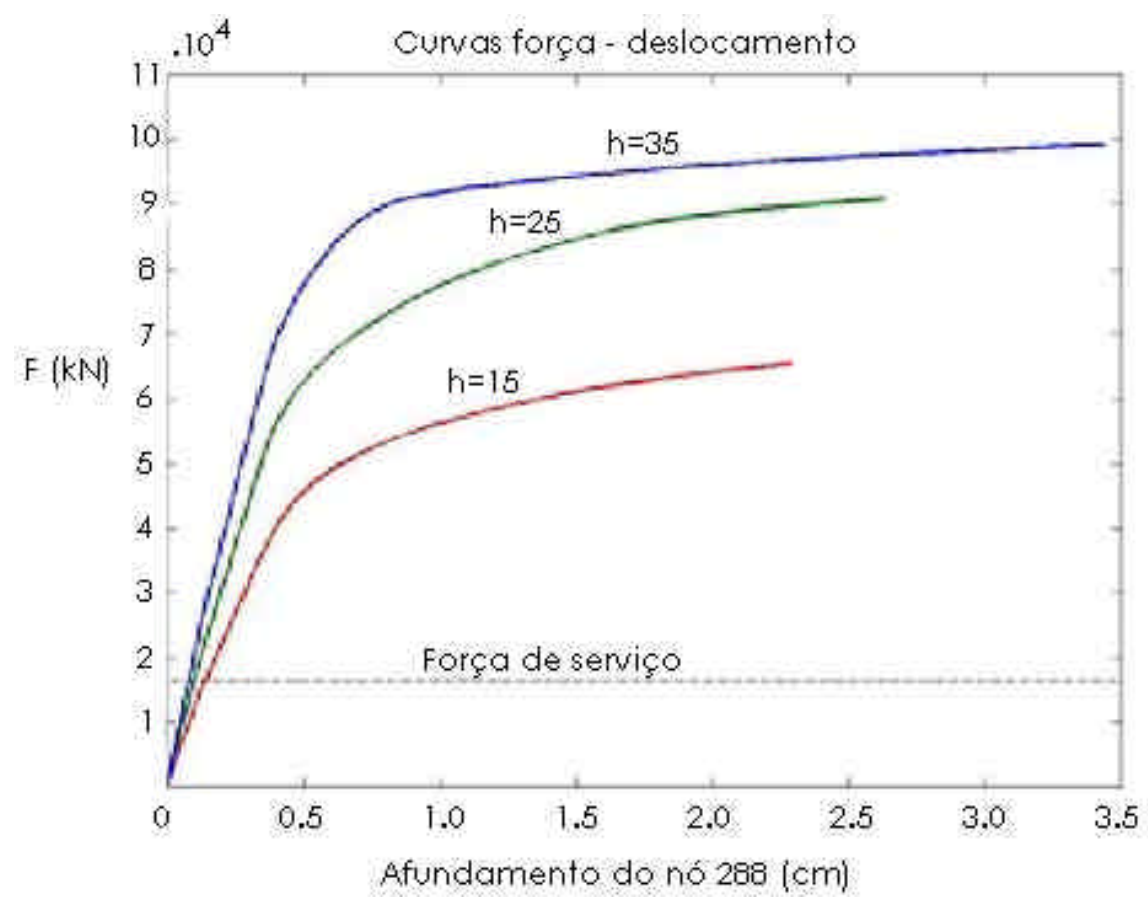

Figura 3.18 - Força-deslocamento para diferentes espessuras da placa (Paliga \& Real, 2003)

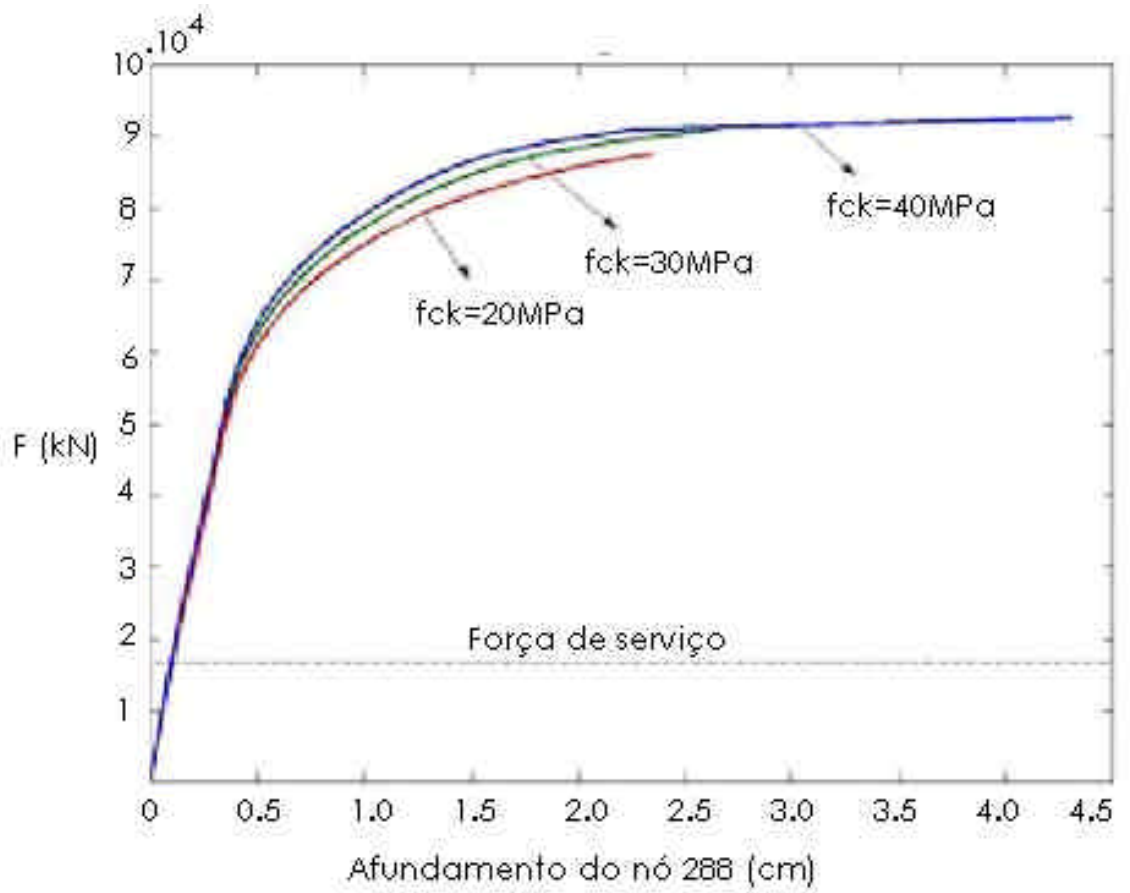

Figura 3.19 - Força-deslocamento para diferentes $f_{c k}$ (Paliga \& Real, 2003) 


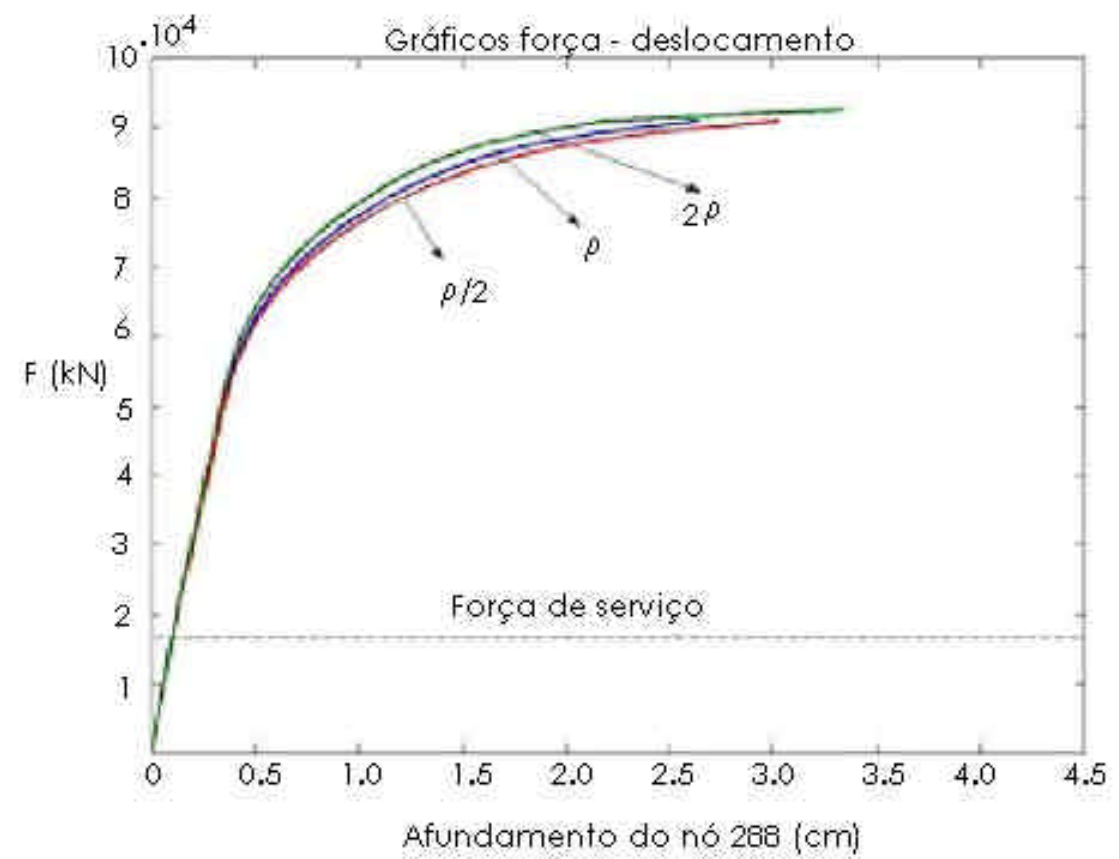

Figura 3.20 - Força-deslocamento para diferentes taxas de armadura (Paliga \& Real, 2003)

Verificou-se que a espessura da laje e o coeficiente de reação do solo têm maior influência nos deslocamentos que a resistência do concreto e a taxa de armadura.

\subsubsection{BUCH (1999)}

Buch (1999) apresenta um trabalho numérico-experimental para verificar os fatores que interferem na transferência de carregamento através de juntas de pavimentos rígidos, por interação dos agregados.

Foram avaliados os seguintes parâmetros:

- Espessura do pavimento

- Módulo de reação do subleito

- Fator de intertravamento dos agregados

O concreto foi modelado como um sistema de duas fases: agregado e matriz. Os deslocamentos com o pavimento carregado e descarregado eram computados, assim como a resistência ao cisalhamento por meio da junta. Verificou-se a queda de transferência conforme aumenta o número de ciclos de carregamento, o que justifica a falência de juntas em pavimentos de concreto que inicialmente deveriam resistir aos esforços estáticos. 


\subsection{MODELAGEM NUMÉRICA DO CONCRETO ARMADO}

Em uma escala macroscópica, os materiais compostos são normalmente modelados como homogêneos. Este é o caso do concreto simples ou reforçado com fibras. Entretanto, segundo CEB (1996), no concreto armado, O comportamento mecânico dos dois materiais é muito diferente e a distribuição da armadura costuma ser desuniforme. Portanto deve-se procurar modelar os materiais individualmente. Elementos finitos distintos devem ser usados para $\circ$ concreto e para a armadura. Para o concreto pode-se usar elementos tri, ou bidimensionais, dependendo da análise, enquanto para a armadura podem ser adotados elementos de treliça.

Segundo o CEB (1996), considerar todos os modelos de escala microspópica tanto do aço quanto do concreto, a fim de prever o comportamento até o esforço último, para todos os casos de carregamento, não é tarefa fácil. Mesmo com recursos poderosos disponíveis, a aplicação para estruturas reais pode ser limitada pela grande exigência de tempo e memória computacional. Por esse motivo temse procurado o desenvolvimento de modelos macro para resolver problemas de concreto armado.

A maioria dos programas de elementos finitos que permite análise não-linear não

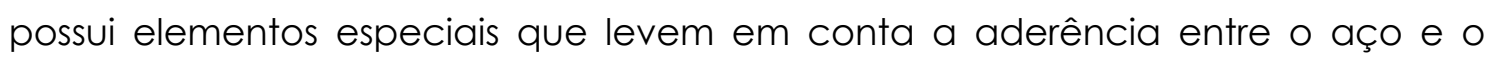
concreto. Essa aderência é simulada pela curva tensão-deformação após a fissuração do concreto. Segundo Belletti, Cerioni \& lori (2001) a relação entre as tensões em duas barras de aço é governada pela contribuição do concreto são entre fissuras.

O comportamento do concreto à compressão é muito diferente da tração, principalmente após a fissuração. No concreto simples, após a abertura de uma fissura, o comportamento, nos planos paralelos ao de fissuração, é o mesmo do concreto não fissurado. Por outro lado, no concreto armado esse comportamento é afetado pela componente de tração normal à fissura, em virtude da transferência de força para a armadura. Na compressão o concreto apresenta comportamento mais isotrópico. 
Os programas de elementos finitos com modelo de material para concreto podem apresentar sub-modelos diferentes para comportamentos dominados pela compressão ou pela tração.

\subsubsection{CONCRETO TRACIONADO}

O comportamento do concreto na tração uniaxial com deformação controlada está ilustrado na figura 3.21. O ponto A corresponde ao máximo carregamento com comportamento tensão-deformação linear. Logo após este estágio ocorre uma região de microfissuração e a força atinge o ponto máximo B. Após a força máxima as fissuras vão se concentrando e aparece um ramo descendente na curva tensão-deformação, ponto C. A ruptura final do corpo-de-prova ocorre numa única fissura.

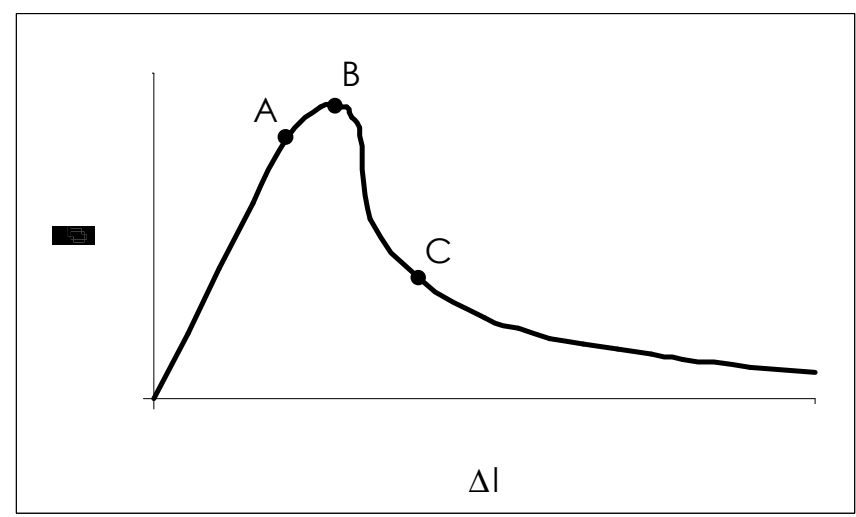

Figura 3.21 - Comportamento do concreto tracionado (CEB, 1996)

Alguns modelos para o comportamento pós-pico do concreto tracionado estão apresentados nas figuras 3.22.a a 3.22.f.

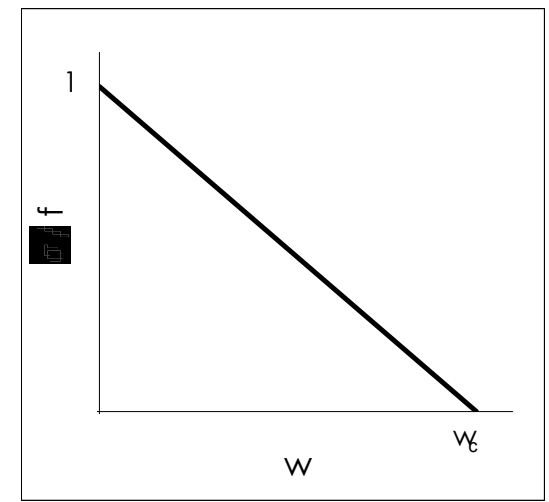

Figura 3.22.a - Modelo linear (CEB, 1996)

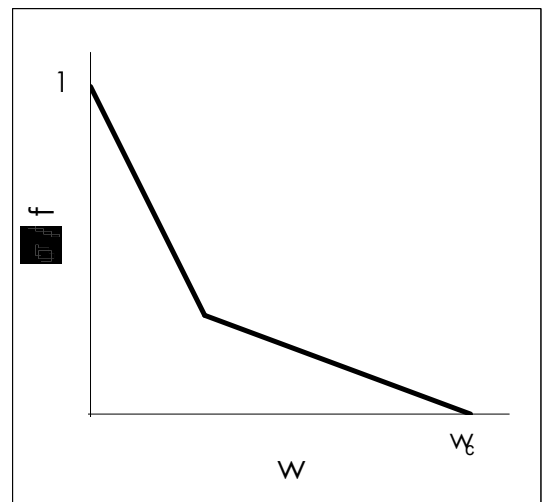

Figura 3.22.b - Modelo bilinear - Petersson (CEB, 1996) 


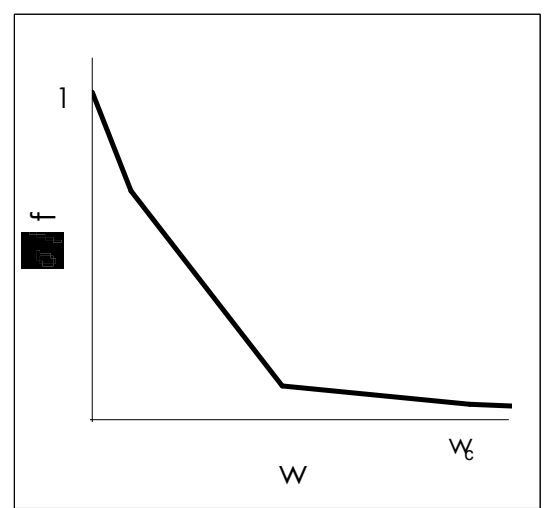

Figura 3.22.c - Modelo multilinear Gustafsson (CEB, 1996)

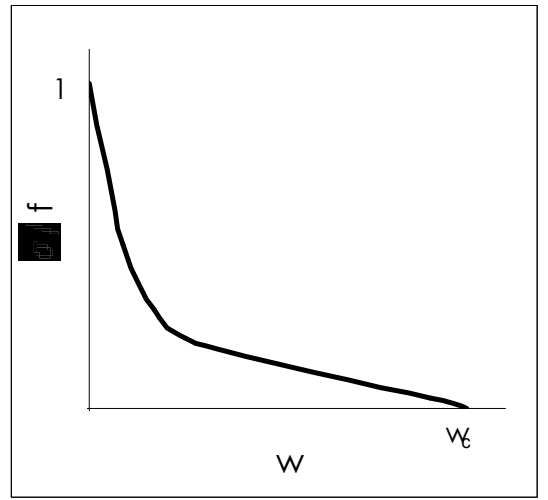

Figura 3.22.e - Cornelissen et al. (CEB, 1996)

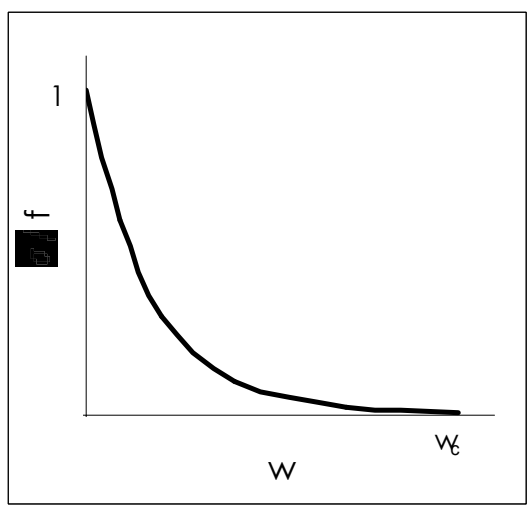

Figura 3.22.d - Gopalaratnam \& Shah (CEB, 1996)

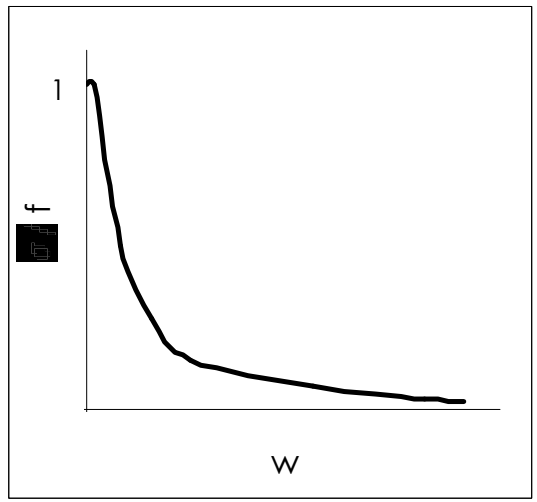

Figura 3.22.f- Dada (CEB, 1996)

Com exceção do modelo linear, que é bastante simplificado, os demais apresentam resultados qualitativamente semelhantes.

Ao contrário do carregamento monotônico, apenas poucos modelos estão disponíveis para o caso de carregamento cíclico. O modelo proposto por Rots et al. (s.d), mostrado pelo CEB (1996), está apresentado na figura 3.23. Este modelo negligencia os ciclos de histerese aproximando-se grosseiramente do comportamento real e é mais apropriado apenas quando os efeitos de dano do carregamento cíclico puderem ser negligenciados.

O modelo de Reinhard et al. (s.d), apresentado pelo CEB (1996), representa bem os ciclos de histerese, mas apresenta a desvantagem de necessitar de um valor para $\Delta \sigma$ no começo do descarregamento. Este valor depende das tensões inferiores. 


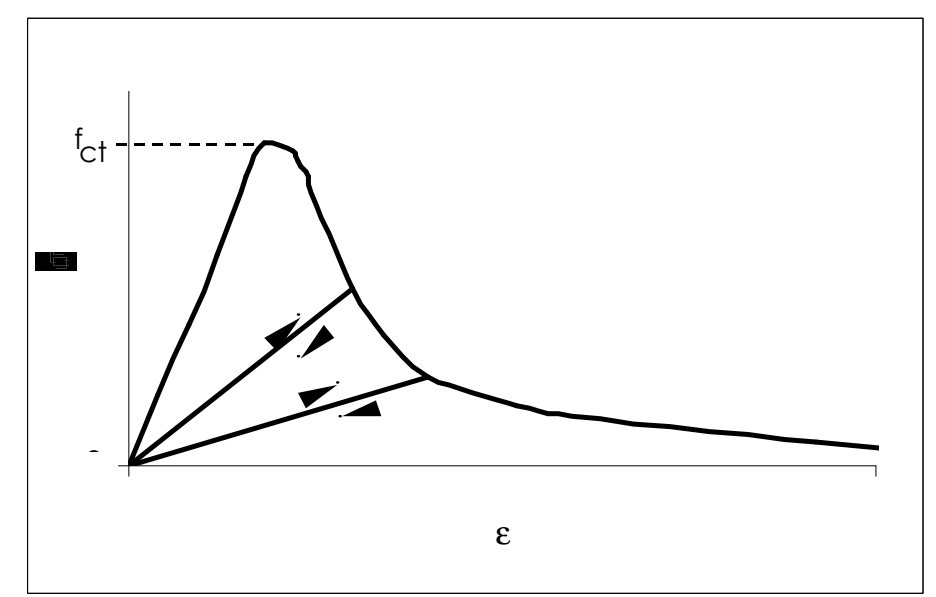

Figura 3.23 - Modelo de Rots et al. para concreto tracionado sob carregamento cíclico (CEB, 1996)

Quando a tensão de tração atinge a superfície de ruptura, considera-se que há o aparecimento de fissura. Portanto é necessária a adoção de um critério de resistência para o início da fissuração. Para a representação da fissura tem-se adotado dois métodos: a fissura discreta e a fissuração distribuída. Segundo Kwan \& Bilington (2001), a fissura discreta é representada por uma descontinuidade geométrica com o uso de elementos de contato ou combinando elementos de contorno com elementos finitos, e no método das fissuras distribuídas, o material é tratado como um contínuo, com redução das propriedades de rigidez.

O método da fissura discreta é mais apropriado para estruturas onde o comportamento dominante é o de cisalhamento e quando é necessário calcular a abertura da fissura. Quando o comportamento é governado por uma ou poucas fissuras ou é necessário um estudo localizado, o método da fissura discreta deve ser o caminho adotado. A fissura discreta aproxima o conceito de fratura, quando aberturas são introduzidas através de descontinuidades no campo de deslocamentos. Para problemas com fratura distribuída, por exemplo, em paredes com densa armadura distribuída, o método da fissuração distribuída parece mais próximo da realidade. Neste caso as fissuras são espalhadas sobre os elementos de concreto ou sobre o volume de pontos de integração e as descontinuidades são suavizadas. Apenas a matriz da rigidez tangencial no ponto de integração ou do elemento precisa ser modificada, sem modificar a tipologia do elemento. Por esse motivo o método da fissuração distribuída tem tido maior aceitação, principalmente quando há maior interesse no comportamento global da estrutura.

Em trabalhos recentes a orientação da fissura não precisa obedecer à geometria da malha, pois podem ser introduzidos novos nós e ajustados os elementos na 
direção da tensão principal. Automaticamente são introduzidos elementos de contato entre os nós de duas faces fissuradas.

\subsubsection{ARMADURA}

Existe um grande número de modelos fenomenológicos para o comportamento do aço para concreto armado, sob carregamento cíclico. Eles representam o comportamento por meio de parâmetros que não podem ser definidos diretamente pelas características físicas do material.

Segundo O CEB (1996), a maioria dos modelos se preocupa com os ciclos de histerese do aço e não das barras de aço para concreto armado. As barras mergulhadas no concreto não são submetidas a tensões de compressão tão grandes quanto às de tração.

No caso dos pavimentos de concreto armado, onde as tensões são repetidas (mesmo sinal) e de baixa freqüência, pode-se adotar o modelo elastoplástico.

\subsection{CONSIDERAÇÕES FINAIS}

A modelagem numérica é um procedimento poderoso que permite a visualização de diferentes aspectos de uma estrutura, como por exemplo dos pavimentos de concreto. A utilização de métodos como dos elementos finitos permite o estudo de diversos parâmetros que precisam ser negligenciados num estudo analítico. Ainda assim são necessárias algumas simplificações e é preciso adotar modelos que se aproximem, apesar de não representarem exatamente, da realidade da estrutura e de seus materiais.

Encontraram-se na literatura alguns trabalhos de desenvolvimento de modelos de pavimentos de concreto, com base no método dos elementos finitos, mas que não levam em consideração a fissuração do concreto e a contribuição da armadura no comportamento pós-fissuração, sendo esta levada em conta apenas na rigidez dos elementos.

Ao contrário do que adotam alguns autores, a fissuração do concreto não precisa corresponder ao estado limite último do pavimento, visto que após a formação das fissuras o aço continua restringindo sua abertura, com o incremento de um 
certo número de ciclos, até a ruína, quando a fissura atinge a superfície. No projeto deve ser definido se será ou não admitida a formação de fissuras de tração no concreto, para definir o que indica o fim da vida útil do pavimento.

Foi encontrado um trabalho mais recente que já desenvolve modelos de pavimentos considerando a fissuração do concreto e a interação com a armadura. 


\section{ENSAIOS DE LABORATÓRIO EM PAVIMENTOS DE CONCRETO}

Como foi estudado no capítulo anterior, o mecanismo de ruína de uma estrutura de concreto armado submetida à fadiga não é necessariamente igual ao modo de ruína da mesma estrutura quando submetida a ações estáticas.

Verificou-se também, na revisão apresentada no capítulo dois, que a fadiga é um fenômeno que ocorre com o material. Por esse motivo, a maioria dos ensaios de fadiga realizados até hoje utilizaram modelos reduzidos para ensaios de tração, de compressão e de flexão. Caracteriza-se o comportamento dos materiais, aço e concreto, quando solicitados a ação cíclica, e consideram-se os resultados para as estruturas reais compostas por esses materiais.

Subramaniam (1999) afirma que os pavimentos rígidos são submetidos a uma combinação biaxial de tensões de tração e de compressão, mas que por meio de um modelo uniaxial é possível obter parâmetros suficientes para prever a resposta dos pavimentos de concreto simples à fadiga.

Childs (1945) realizou ensaios em laboratório com placas totalmente apoiadas. Seu estudo tinha como principal objetivo analisar os efeitos do tipo de eixo e do espaçamento entre rodas na deformação do concreto por flexão. Ele aplicou ação até a força última, mas não realizou ensaios de fadiga.

Carlton \& Behrmann (1958) realizaram ensaios estáticos e de fadiga, em escala real, em placas de aeroportos, para a US Army Corps of Engineers. Eles aplicaram carregamento com a configuração dos eixos da época. A ruína era definida quando $50 \%$ da placa apresentava fissuras visíveis na superfície. O carregamento correspondente à primeira fissura não era registrado.

Childs \& Kapernick (1959) ensaiaram placas, em laboratório, analisando o efeito das sub-bases no comportamento da placa. Apenas a força última era registrada e também não foram realizados ensaios de fadiga. 
Darter \& Barenberg (1977) apresentaram um modelo de fadiga para pavimentos de concreto simples, desenvolvido com base em ensaios de vigas simplesmente apoiadas. A pedido da PCA, Packard \& Tayabji (1985) também apresentaram modelo semelhante a partir de ensaios de laboratório em vigas de concreto.

Dados sobre o comportamento de pavimentos de concreto simples ou com armadura de retração, sob carregamento repetido, foram reunidos por órgãos americanos como AASHTO, PCA e US Army Corps of Engineers, por meio de instrumentação de pavimentos em utilização e de pistas experimentais. Alguns pesquisadores reuniram esses resultados e apresentaram modelos de fadiga aplicados aos pavimentos de concreto simples. Entre eles pode-se citar Parker (1977) e Barker (1981).

Diferente do que acontece nas pistas reais ou experimentais, onde normalmente se estabelece um grau de fissuração para definir a ruína do pavimento, em laboratório a ruína costuma ser definida pela ocorrência de uma fissura que atravessa toda a espessura da placa e a impede de continuar resistindo ao carregamento.

Com o objetivo de estabelecer parâmetros para o dimensionamento de ensaios que possam representar o comportamento dos pavimentos estruturalmente armados à fadiga, serão apresentados, neste capítulo, alguns trabalhos experimentais realizados em placas de concreto simples e armado.

\section{1 LOSBERG (1960)}

Em 1945, o "Stockholm Airport Building Committee" propôs a implantação de um aeroporto para tráfego intenso, ao norte da cidade de Stockholm, onde as condições do solo são extremamente ruins. Para solucionar este problema, o professor Hjalmar Granholm, do Departamento de Engenharia Estrutural da "Chalmers University of Tecnology", propôs o dimensionamento do pavimento como uma laje de concreto armado. O desenvolvimento de uma pesquisa sobre esse tipo de estrutura de pavimento foi desenvolvida pelo então assistente de pesquisas, Anders Losberg, que em 1960 publicou o livro "Structurally reinforced concrete pavements". Até esse período, os únicos tipos de armadura utilizada em pavimentos de concreto tinham a função de controlar a abertura das fissuras, provenientes da retração do concreto e dos efeitos de variações térmicas. Como 
essas armaduras eram posicionadas no plano médio da placa, ou acima dele, tinham pouca contribuição na resistência ao momento fletor positivo, provocado pelo tráfego de veículos.

O pavimento de concreto estruturalmente armado foi investigado experimentalmente por Losberg, que realizou ainda um estudo sobre a aplicação da Teoria da Elasticidade e do Método das Charneiras Plásticas para esse tipo de pavimento. Os resultados dos modelos de laboratório foram comparados com os de pistas de aeroportos em funcionamento. Dessa forma os resultados teóricoexperimentais foram adaptados às situações práticas.

Losberg realizou três tipos de ensaios. O estudo mais sistemático de várias configurações de pavimentos de concreto armado, sob diversas condições, foi realizado com o auxílio de ensaios de modelos em escala reduzida. As placas ensaiadas tinham formato octogonal ou circular com diâmetros entre $2,5 \mathrm{~m} \mathrm{e}$ $3,5 \mathrm{~m}$. A espessura variou entre $2 \mathrm{~cm}$ e $8 \mathrm{~cm}$. Foi utilizada armadura inferior ou, em alguns casos, armadura dupla de telas soldadas ou de barras de aço posicionadas perpendicularmente. Como sub-base elástica, Losberg utilizou placas de fibras de madeira com alta porosidade, variando a espessura e a elasticidade. Como as propriedades do solo são diferentes das características das placas de madeira, Losberg ensaiou duas placas apoiadas em solo natural, em escala real. Foi escolhida uma argila da cidade de Gothenburg. Nesses ensaios foi dada atenção especial às pressões no solo.

Com os ensaios das placas sobre pranchas de madeira, Losberg procurou verificar se, e até que ponto, os pavimentos estruturalmente armados podem ser considerados como placas elásticas, obedecendo, portanto, à teoria da elasticidade.

Para análise dos diversos ensaios, de acordo com a teoria da elasticidade, é essencial a determinação dos valores das constantes como a rigidez da placa, dada pela equação (4.1), e as constantes elásticas do solo: a constante de resiliência - k-, ou o módulo elástico - C - dado pela equação (4.2).

$C_{p}=\frac{E \cdot i}{\left(1-v^{2}\right)}$

sendo: 
- E: módulo de elasticidade da placa;

- i: momento de inércia da placa por unidade de largura;

- $v$ : coeficiente de Poisson da placa.

$$
C_{s}=\frac{E_{s}}{\left(1-v_{s}^{2}\right)}
$$

sendo:

- Es: módulo de elasticidade do solo;

- $v_{\mathrm{s}}$ : coeficiente de Poisson do solo.

Segundo Losberg essa é uma das maiores dificuldades na análise de ensaios, visto que a placa e o solo são considerados com características elásticas idealizadas, mas as chamadas constantes, na verdade variam.

\subsubsection{DETERMINAÇÃO DA RIGIDEZ À FLEXÃO E DO MOMENTO ÚLTIMO}

Segundo Losberg, a determinação da rigidez à flexão de uma placa de concreto estruturalmente armada é particularmente complexa. O pavimento pode ser considerado elástico e isotrópico apenas no caso de tensões muito baixas, antes da fissuração da zona de tração do concreto (Estádio I). Assim que é iniciada a fissuração, a rigidez diminui. Conforme aumenta a intensidade da ação, a rigidez decresce. Em uma determinada etapa, a placa pode ser dividida em diferentes zonas, com características elásticas completamente diferentes. Nas proximidades do centro de ação, o concreto desenvolve fissuras de tração na face inferior e está no chamado Estádio II (ou no caso de ações mais elevadas, na ruína, no Estado Limite Último, com escoamento das barras da armadura). Fora desse centro há uma região de inversão do sinal do momento fletor e as tensões na placa são muito pequenas, onde se pode assumir que o concreto não tem nenhuma fissura. Para placas com armadura dupla (com armadura posicionada junto às faces inferior e superior), existe uma zona adicional com fissuras de tração na face superior, e além dela, novamente, uma região onde os momentos decrescem e o concreto se apresenta não fissurado. As várias regiões se sobrepõem e os limites se tornam mais visíveis, conforme a intensidade das ações aumenta. Nessas condições é particularmente difícil determinar um valor médio para a rigidez da placa à flexão, um valor que possa ser aplicado quando se 
utilizam teorias que assumem que a laje é elástica e isotrópica e tem rigidez constante à flexão.

Para estudar as características elásticas dos pavimentos de concreto, Losberg ensaiou faixas simplesmente apoiadas com carregamento nos terços do vão. Esses ensaios foram chamados de detail tests e foram realizados simultaneamente aos ensaios das placas. Em alguns dos ensaios as faixas foram extraídas de regiões não danificadas das placas. Os resultados permitem o traçado de curvas que relacionam o momento fletor com o deslocamento ou o momento fletor com a curvatura. A configuração dos detail tests está apresentada na figura 4.1, na qual os comprimentos $l_{1}$ e $l_{3}$ representam as distâncias dos pontos de aplicação de força até os apoios. O deslocamento por solicitação do momento fletor, $\delta$, foi medido numa distância $l_{2}$ entre os pontos de aplicação de força. Normalmente essas faixas tinham $30 \mathrm{~cm}$ de largura.

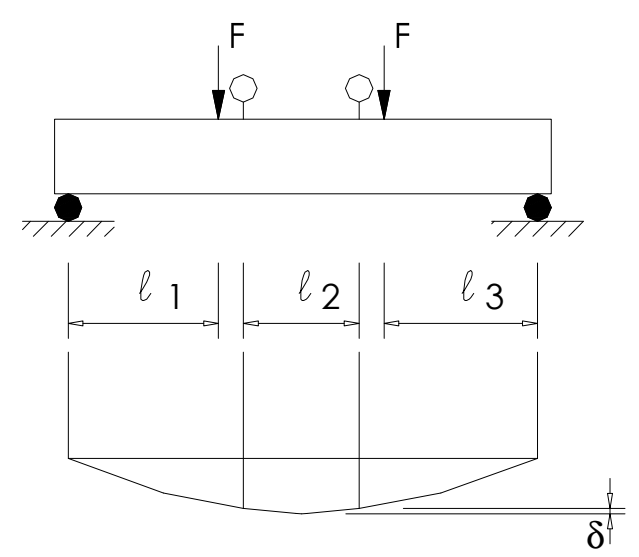

Figura 4.1 - Configuração dos detail tests

O raio de curvatura constante que é obtido no trecho de comprimento $I_{2}$ indicado na figura 4.1 é dado pela equação(4.3).

$\frac{1}{r}=\frac{8 \cdot \delta}{\ell_{2}^{2}}$

A figura 4.2 mostra uma relação típica entre o momento fletor e o raio de curvatura, para uma placa com apenas uma armadura inferior. O primeiro segmento de reta representa o Estádio I, antes do início da formação de fissuras na zona de tração. Quando é iniciada a fissuração, a curva muda gradualmente até assumir a forma de um segmento reto, que corresponde à deformação da placa com a zona de tração no Estádio II. Finalmente, quando o aço começa a 
plastificar, a curva se torna praticamente horizontal, correspondendo ao momento fletor último.

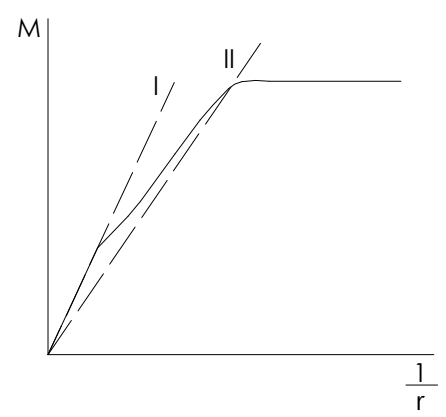

Figura 4.2 - Típica relação momento - raio de curvatura para placas com armadura simples

A inclinação da primeira parte da curva corresponde à rigidez da placa à flexão, no Estádio I. O módulo de elasticidade do concreto, quando submetido a forças reduzidas, pode ser determinado por essa inclinação. A inclinação da curva secante ao ponto de plastificação corresponde teoricamente à rigidez à flexão no Estádio II. Esse valor corresponde ao obtido no cálculo teórico baseado no momento de inércia para seção fissurada na zona de tração, e é chamado de módulo secante.

Ensaios como esses dão alguma idéia de como varia a rigidez à flexão com a variação da ação e entre diferentes zonas nos ensaios das placas. Enquanto são aplicadas forças pequenas, a rigidez à flexão corresponde ao segmento de reta I da figura 4.2. Com as restrições pertinentes, o módulo secante, correspondente ao segmento II, pode ser adotado quando a ação estiver próxima daquela que provoca o colapso.

O momento último das placas submetidas à flexão, com armadura na zona tracionada, é obtido, conforme mencionado, pela parte horizontal da curva momento-curvatura obtida nos detail tests. O valor último para momentos negativos nas placas foram avaliados por ensaios similares em faixas, que foram ensaiadas com a face superior tracionada.

\subsubsection{PROCEDIMENTO DE ENSAIO DAS PLACAS}

Para medir os deslocamentos da placa, Losberg utilizou relógios comparadores espaçados de 20 a $50 \mathrm{~cm}$, posicionados perpendiculares em duas direções, como pode ser visto nas figuras 4.3 e 4.4 . 


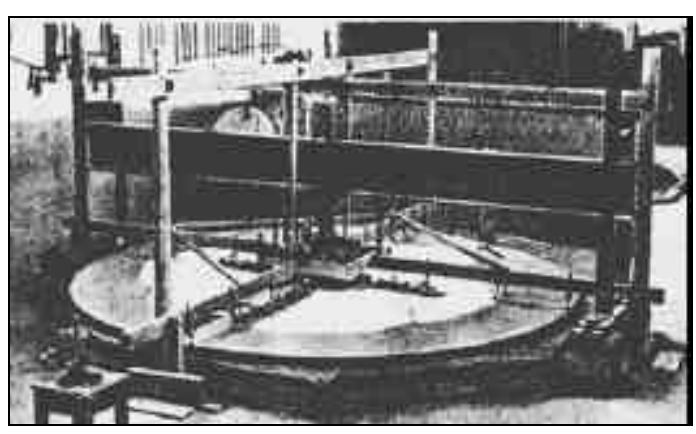

Figura 4.3 - Ensaio em placa circular, Losberg (1960)

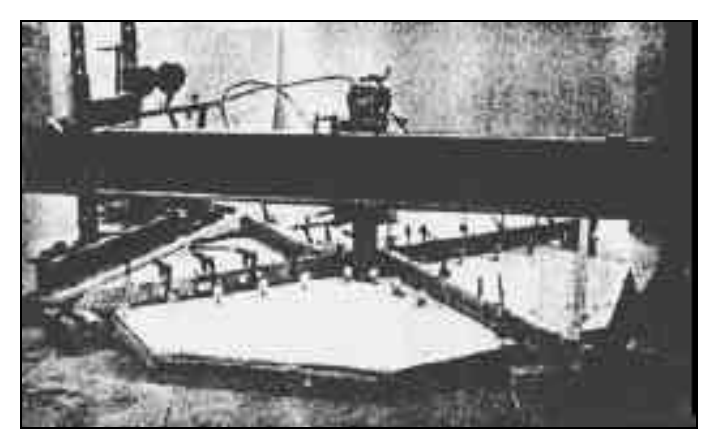

Figura 4.4 - Ensaio em placa octogonal, Losberg (1960)

Para medir a curvatura entre dois pontos foi utilizado o sistema mostrado na figura 4.5, esquematizado na figura 4.6. Para estimativa do momento fletor, foram utilizados os gráficos momento-curvatura determinados a partir dos detail tests.

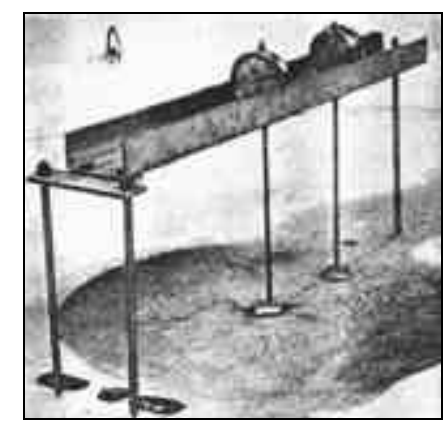

Figura 4.5 - Sistema de medição de curvatura

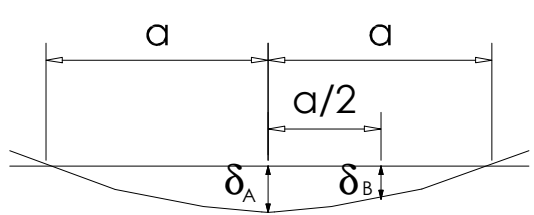

Figura 4.6 - Esquema de medição da curvatura

A partir das medidas de deslocamento $\delta_{\mathrm{A}}$ e $\delta_{\mathrm{B}}$ indicadas na figura 4.6 , determinase a curvatura no trecho de comprimento $2 a$ :

$\frac{1}{r_{\text {centro }}}=\frac{1}{a^{2}} \cdot\left[10 \cdot\left(\delta_{A}-\delta_{B}\right)-\frac{2}{3} \cdot \delta_{B}\right]$

Em alguns ensaios foram utilizados extensômetros para medir a tensão e determinar o início da fissuração na face superior da placa.

As forças eram aplicadas com incrementos de $1 \mathrm{kN}$ e $2 \mathrm{kN}$ e todos os instrumentos foram lidos em cada passo. Foi avaliada a influência do tipo de ação, variando a configuração e aplicando forças fixas e móveis.

Para forças mais elevadas, foram observados: a formação de fissuras e o processo de ruína. Para facilitar a visualização, a superfície superior foi pintada de branco. Observou-se a formação de uma fissura circular, concêntrica à área de aplicação da força, que no início é percebida em apenas pequenos arcos e depois se 
propaga até a formação do círculo completo. No caso de armadura dupla, as fissuras tiveram aberturas menores e formaram vários círculos concêntricos.

Depois de ensaiada, cada placa foi removida e serrada, para verificar sua espessura e o posicionamento exato da armadura.

\subsubsection{DISCUSSÃO DOS RESULTADOS}

Losberg verificou que os fatores que provocam imprecisão na determinação das constantes $D$ e $k$ têm pouca influência nos resultados, visto que variações nessas constantes alteram muito pouco a distribuição relativa dos esforços. Por outro lado, a força e o momento fletor têm ligação muito estreita.

Segundo Losberg, os ensaios mostraram que a Teoria da Elasticidade não é adequada para cálculo do momento fletor e da força última. Isso pode ser explicado porque de fato a zona central da placa, próximo à ruptura, assume características plásticas. Isso influencia os valores de momento, não apenas na zona central, mas em toda placa. Para determinação dos deslocamentos, a teoria da elasticidade se apresentou adequada, visto que a plastificação da zona central não influencia significativamente os deslocamentos verticais no restante da placa. Os valores teóricos são mais próximos dos experimentais, quando são aplicadas ações de menor intensidade, mas não se afastam muito, com o aumento da força aplicada.

Em resumo, pode-se concluir que a Teoria da Elasticidade pode ser aplicada, com bastante precisão, aos pavimentos de concreto estruturalmente armados, para o cálculo da deformação e dos momentos fletores enquanto a placa se mantém na fase elástica, isto é, não fissurada. Os deslocamentos podem ser estimados com uma certa aproximação mesmo para estágios mais avançados do carregamento. No cálculo, a rigidez da placa à flexão deve ser estimada pelo módulo secante no ponto de escoamento. Para a determinação da força última da face superior, a Teoria da Elasticidade não é adequada, como era de se esperar.

Segundo Losberg, a Teoria da Elasticidade apresenta uma razoável aproximação no cálculo de momentos fletores e de tensões em pavimentos de concreto estruturalmente armados, no caso da plastificação da armadura inferior se restringir à zona central de aplicação do carregamento. Quando são aplicados carregamentos maiores e a plastificação se estende para além da região central, 
essa teoria não dá nenhuma idéia do aumento das tensões e do momento fletor negativo que provoca fissuras na face superior do pavimento.

O solo utilizado nos ensaios se comportou aproximadamente como um meio elástico.

Losberg (1960) aconselhava que, em virtude da inexistência de dados estatísticos para pistas de concreto estruturalmente armado, adote-se, para 0 dimensionamento, um coeficiente de segurança elevado, entre 1,6 e 2. Dependendo da aplicação do pavimento, onde não houver risco de acidentes, e dependendo do custo de manutenção, esse coeficiente pode ser reduzido.

\subsection{BuLl E SALMO (1992)}

Bull e Salmo ensaiaram unidades pré-fabricadas de pavimento de concreto para tráfego pesado. Essas unidades são indicadas para indústrias, portos, áreas de estocagem, áreas de estacionamento, rodovias e aeroportos. Permitem uma rápida manutenção, pois são produzidas em fábrica, com alto controle de qualidade. As unidades danificadas são rapidamente removidas e substituídas por unidades novas. Segundo os autores, a manutenção pode ser feita em três horas.

As unidades ensaiadas eram retangulares, com lado maior de no máximo $244 \mathrm{~cm}$. As espessuras variaram entre 7,5 e $22 \mathrm{~cm}$, dependendo da armadura ou da protensão utilizada.

\subsection{PROCEDIMENTO DE ENSAIO}

Na primeira série de ensaios, foi analisada uma placa com largura de 60,8 cm, comprimento de $244 \mathrm{~cm}$ e espessura de $14 \mathrm{~cm}$. A placa foi apoiada sobre uma base de $90 \mathrm{~cm}$ de material granular e $5 \mathrm{~cm}$ de areia, contidos em uma tanque quadrado de $4 \mathrm{~m}$ de lado, apoiado sobre um piso de concreto rígido. $\mathrm{O}$ esquema do ensaio está representado na figura 4.7. Foi utilizada armadura dupla com área de $2,82 \mathrm{~cm}^{2} / \mathrm{m}$. A força foi aplicada com atuador hidráulico em uma placa de aço quadrada, centralizada, com $20 \mathrm{~cm}$ de lado, apoiada sobre uma camada de material flexível. Os ciclos de aplicação das forças foram monitorados por um programa de computador. Foram aplicadas as forças e os números de ciclos 
indicados na tabela 4.1, na qual também são apresentadas as pressões de contato correspondentes a cada força.

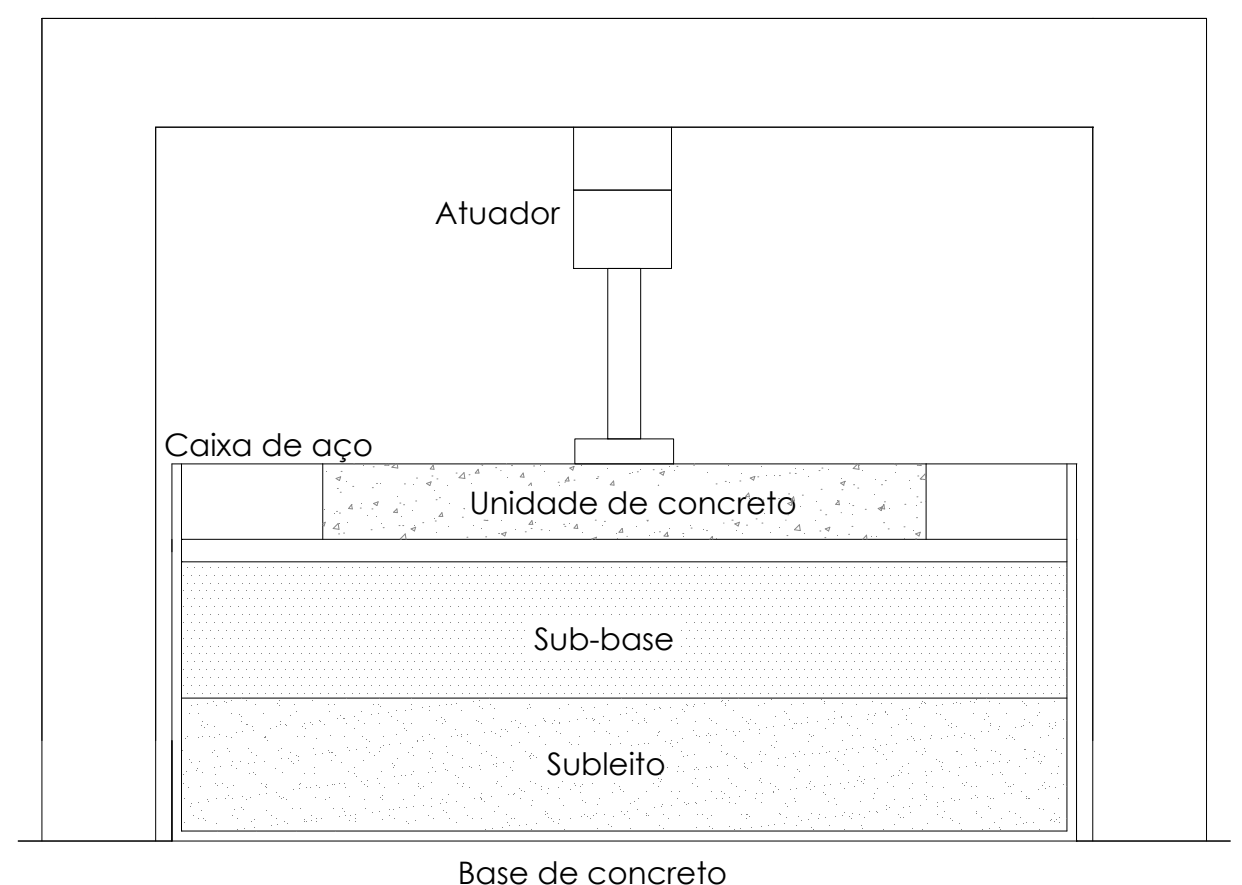

Figura 4.7 - Esquema de ensaio de unidades pré-fabricadas de pavimento de concreto (Bull \& Salmo - 1992)

Tabela 4.1 - Força, pressão de contato e número de ciclos aplicados na primeira série de ensaios descrita por Bull \& Salmo (1992)

\begin{tabular}{ccc}
\hline Força $(\mathrm{kN})$ & Pressão de contato $(\mathrm{MPa})$ & Número de ciclos \\
\hline 35 & 0,875 & 900 \\
45 & 1,125 & 700 \\
55 & 1,375 & 500 \\
65 & 1,625 & 1500 \\
75 & 1,875 & 1200 \\
90 & 2,250 & 800 \\
110 & 2,750 & 800 \\
130 & 3,250 & 800 \\
150 & 3,750 & 1200 \\
170 & 4,250 & 1200 \\
220 & 5,500 & 600 \\
\hline
\end{tabular}

Depois de um total de 4800 ciclos de uma força de $75 \mathrm{kN}$, apareceu a primeira fissura, atravessando a espessura da superfície inferior até a superior. A abertura da fissura cresceu até 4,2 mm, com a força de $220 \mathrm{kN}$. O ensaio foi interrompido aos 10200 ciclos, por causa do escoamento das barras da armadura inferior.

Segundo o autor, nos ensaios de laboratório, as forças podem ser medidas e as tensões calculadas. Nos ensaios das placas pré-moldadas, as deformações podem ser facilmente medidas com o auxílio de extensômetros, e as aberturas de 
fissura, usando Demec gauges. Essas medições foram realizadas na segunda série de ensaios, apresentada por Bull e Salmo.

Nessa segunda série, foram estudadas placas quadradas de $200 \mathrm{~cm}$ de lado com $14 \mathrm{~cm}$ de espessura. Cada unidade foi pré-fabricada com concreto de resistência igual a 50 MPa e com armadura dupla de aço de alta resistência. As placas foram apoiadas no mesmo tanque do ensaio anterior, com a superfície coberta por 10 $\mathrm{cm}$ de poliestireno, representando um CBR de $2,5 \%$.

Foram aplicados dois tipos de carregamentos: forças centralizadas, e duas forças simétricas em relação ao centro ou à diagonal da placa. Para aplicação da força centralizada, foi utilizada placa de aço retangular com lados de 17,8 e 16,2 cm. As deformações e as aberturas de fissuras foram medidas por meio de uma combinação de Demec gages e extensômetros mecânicos e elétricos. Esses extensômetros eram colocados na superfície e na lateral das placas, em posições adequadas. Além das deformações e do número de aplicações de forças, eram registrados os deslocamentos verticais da placa.

Inicialmente foram aplicados carregamentos com incrementos de $10 \mathrm{kN}$ até atingir $40 \mathrm{kN}$, com objetivo de acomodar a unidade de concreto na fundação. Para iniciar o ensaio propriamente dito, foi aplicado carregamento de $50 \mathrm{kN}$, nos de carga centralizada, ou $25 \mathrm{kN}$ em cada uma das duas áreas simétricas. Foram aplicados 25, 50, 75 e 100 ciclos, registrando os dados a cada intervalo. Depois passou-se a incrementos de 100 até atingir 1000 ciclos. Após esse número de repetições era incrementado o valor da força.

Até o início da fissuração visual, as deformações eram lidas com extensômetros elétricos. A partir daí, eram instalados instrumentos mecânicos para medir a abertura das fissuras. A primeira fissura visível apareceu na borda, no primeiro ciclo de $60 \mathrm{kN}$, para a placa com força no centro. Essa fissura se desenvolveu até o carregamento de $100 \mathrm{kN}$ ser aplicado 1000 vezes. Novas fissuras se formaram com carregamentos de 150, 200 e 300 kN, com 1000 ciclos para cada nível de carregamento. Com o carregamento de $350 \mathrm{kN}$ repetido 600 vezes, apareceram fissuras de cisalhamento na região de aplicação da força. Aos 900 ciclos de $350 \mathrm{kN}$ apareceram fissuras de flexão na superfície da placa. Com 400 kN, conforme aumentava o número de ciclos, aumentava a abertura da fissura no topo da placa. Considerou-se como ruptura a carga de 350 kN, aos 1000 ciclos. 


\subsubsection{DISCUSSÃO DOS RESULTADOS}

Bull e Salmo utilizaram os resultados dos ensaios para estabelecer uma relação das deformações à fadiga com o número de ciclos, chegando à seguinte equação:

$N=1000 \cdot\left(\frac{\varepsilon_{f}}{\varepsilon_{1}}\right)^{3,01}$

sendo:

- $\quad \varepsilon f:$ deformação na ruptura;

- $\varepsilon_{1}$ : deformação correspondente a 1000 ciclos de uma determinada força.

Para previsão da vida à fadiga de uma unidade pré-fabricada de pavimento de concreto, os autores sugerem a equação (2.16).

Porém, o uso dessa equação exige o conhecimento da tensão atuante que pode não ser avaliada corretamente.

Bull e Salmo afirmam que, uma vez fissurado o concreto, sua vida útil passa a depender da armadura. A equação (4.5) pode ser utilizada na previsão dessa vida, relacionando a deformação (abertura das fissuras) com a tensão no aço.

4.3 ROESLER (1998)

Roesler realizou três tipos de ensaios de fadiga em laboratório: em vigas simplesmente apoiadas, em vigas uniformemente apoiadas em sub-base de argila e em placas uniformemente apoiadas sobre sub-base de argila. Seu objetivo era determinar os efeitos da geometria e das condições de apoio na fadiga de pavimentos de concreto simples.

\subsection{METODOLOGIA DE ENSAIO}

Os primeiros ensaios de fadiga foram realizados em vigas simplesmente apoiadas, que tinham seção transversal quadrada de $15,24 \mathrm{~cm}$ de lado e comprimento de $53 \mathrm{~cm}$, com vão livre de $45,72 \mathrm{~cm}$. A segunda série de ensaios foi realizada com vigas uniformemente apoiadas. Essas vigas tinham a mesma seção das primeiras, 
mas o comprimento era de $183 \mathrm{~cm}$. As placas ensaiadas eram quadradas com lado de 1,22 m e 15,24 cm de espessura.

Com os ensaios das placas procurou-se mostrar a diferença entre a fadiga de peças unidirecionais e bidirecionais. Outro aspecto dessa pesquisa foi monitorar visualmente a propagação de fissuras nas vigas e nas placas, limitando-se à análise macroscópica, isto é, onde e quando a fissura começa e como se propaga até a ruptura.

Roesler ensaiou 24 vigas simplesmente apoiadas, 12 para cada dosagem escolhida. Em uma primeira etapa foram ensaiadas estaticamente quatro vigas, para estimar a média do módulo de ruptura, ou resistência à tração na flexão, das outras oito vigas. Esse ensaio auxilia na determinação da ordem de grandeza da tensão a ser aplicada. A geometria do ensaio está mostrada na figura 4.8.

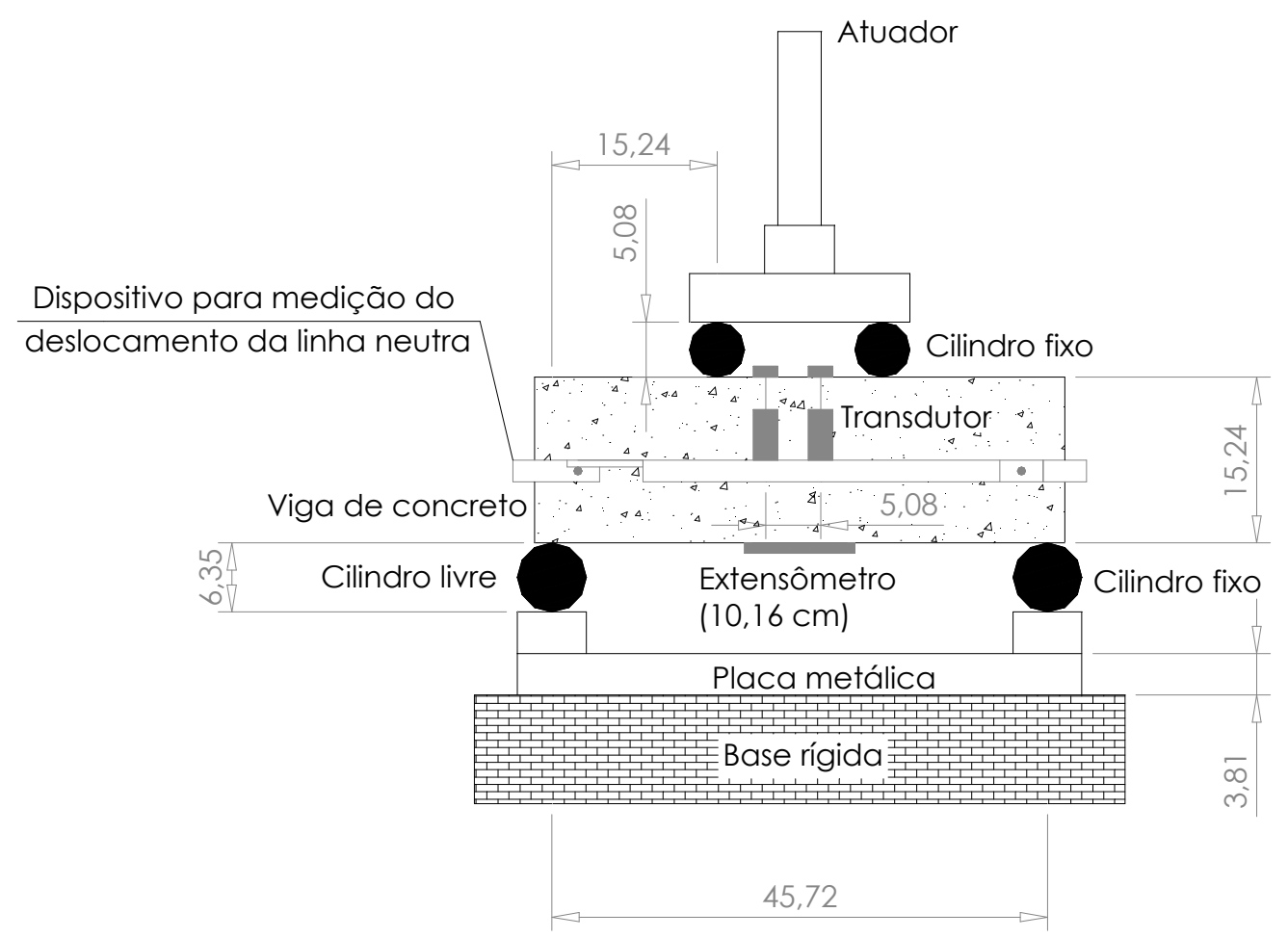

gura 4.8 - Geometria do ensaio de viga simplesmente apoiada (Roesler, 1998) unidade: $\mathrm{cm}$

Todos os ensaios de fadiga em vigas foram previamente condicionados a uma intensidade de tensão entre $30 \%$ e $40 \%$, para assentar o modelo e verificar o funcionamento dos instrumentos. A freqüência de aplicação das forças foi de $3 \mathrm{~Hz}$, sem períodos de folga. Foram adotadas duas intensidades de tensão máxima: $65 \%$ e $90 \%$ da tensão admissível. A tensão mínima era de $10 \%$. 
Roesler decidiu ensaiar também vigas uniformemente apoiadas, por considerar um ensaio intermediário entre as vigas simplesmente apoiadas e as placas. Se o comportamento dessas vigas fosse similar ao das placas, elas constituiriam uma maneira mais fácil de estudar os pavimentos de concreto. A figura 4.9 mostra a configuração do ensaio. A sub-base adotada foi de argila com 58,42 cm de profundidade, com CBR igual a $3 \%$ e um valor de $k$ correspondente a aproximadamente $27 \mathrm{MPa} / \mathrm{m}$.

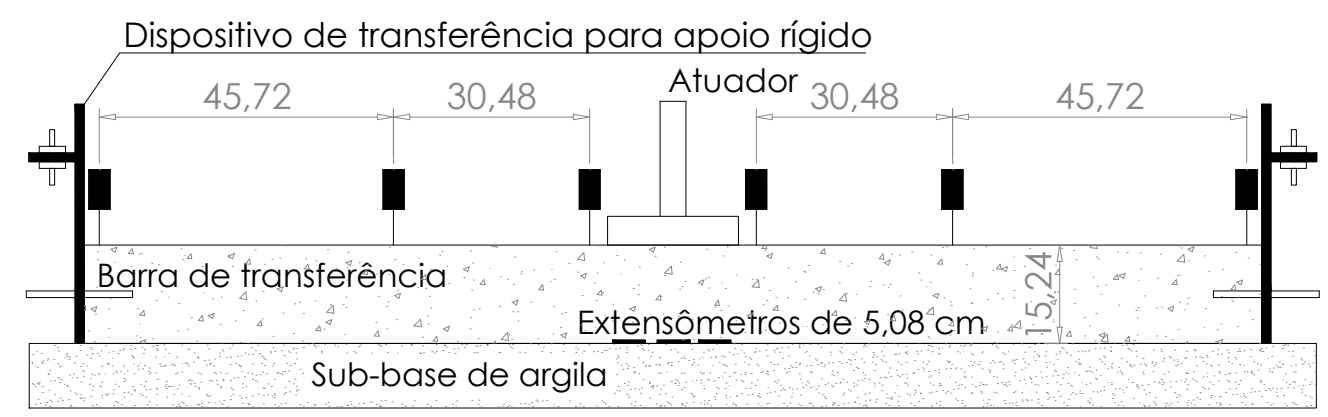

Figura 4.9 - Geometria do ensaio de viga uniformemente apoiada (Roesler, 1998)

Foram ensaiadas duas vigas uniformemente apoiadas sob carregamento estático e 16 à fadiga. A intensidade de tensão variou entre 30 e 50\% da resistência estática. Foi adotada uma freqüência de $2 \mathrm{~Hz}$.

Nos ensaios das placas, Roesler procurou verificar o mecanismo de ruptura por fadiga por meio de monitoramento e observação visual da formação de fissuras e da ruína. Com o objetivo de diminuir o número de variáveis, seria interessante ensaiar placas de dimensões consideradas infinitas, o que na prática exigiria largura de aproximadamente $4 \mathrm{~m}$. Roesler utilizou o programa de pavimentos rígidos - ILLI-SLAB - para analisar a influência da redução das dimensões adotadas em sua tese. A configuração do ensaio está apresentada nas figuras 4.10, 4.11. 


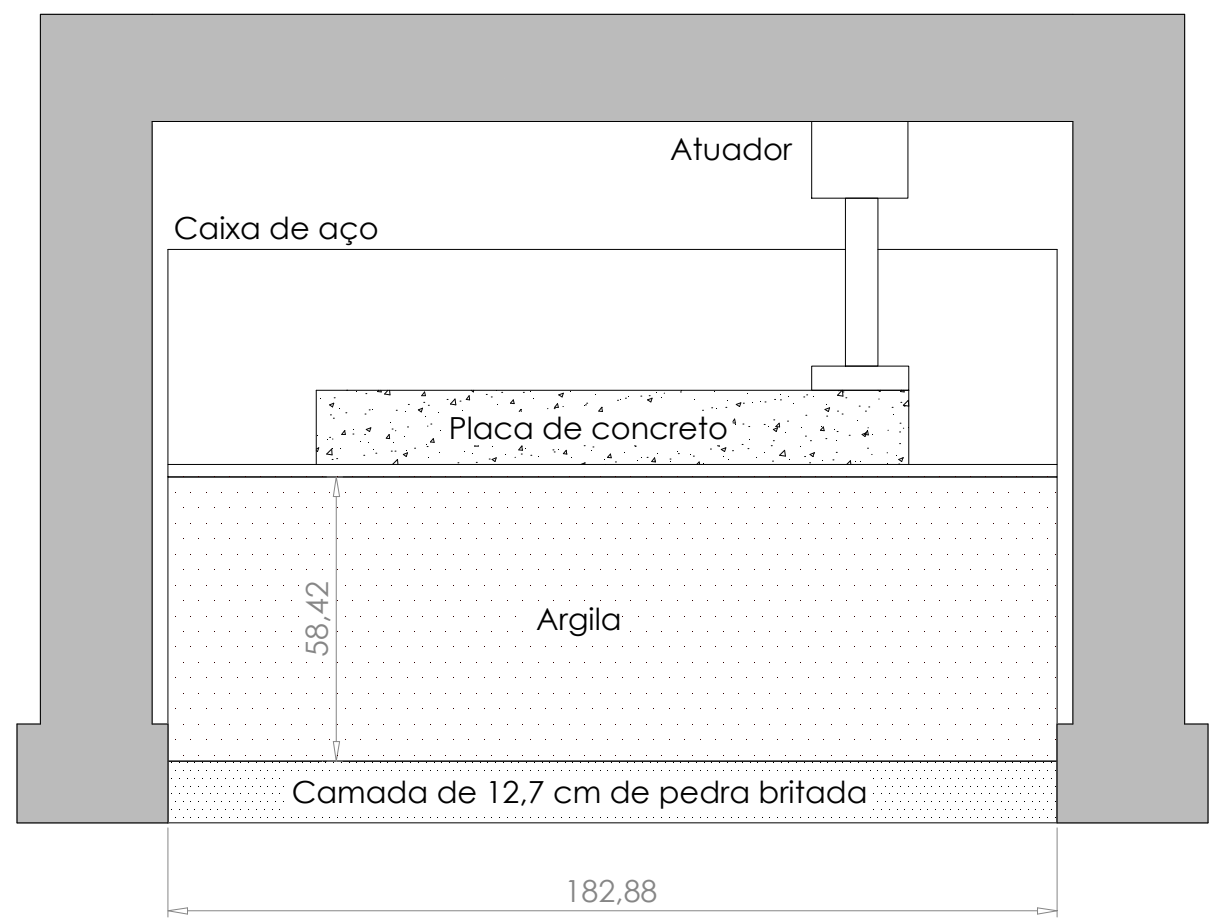

Figura 4.10 - Esquema da vista lateral do ensaio de placa (Roesler, 1998) Dispositivo de transferência de força

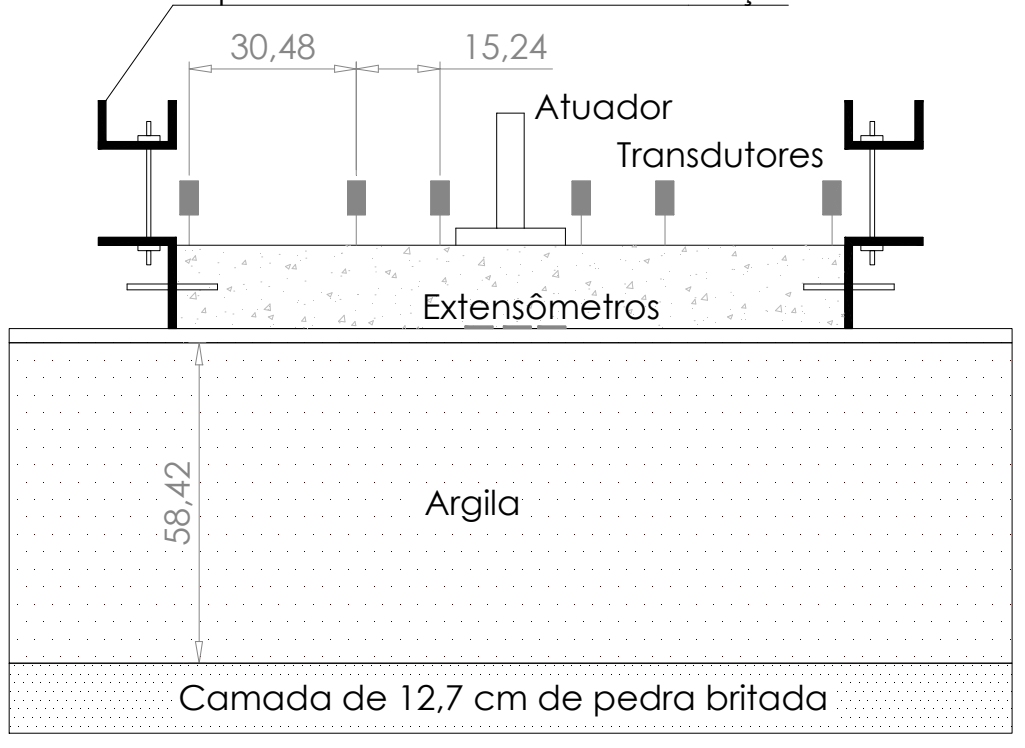

Figura 4.1 1- Esquema da vista frontal do ensaio de placa (Roesler, 1998)

Para cada uma das duas dosagens adotadas, Roesler ensaiou seis placas, e com o mesmo concreto, duas vigas uniformemente apoiadas, 16 vigas simplesmente apoiadas e oito corpos-de-prova cilíndricos para ensaios de compressão. Todas as placas foram levadas até a ruína. De regiões indeformadas das placas já rompidas, foram retirados corpos-de-prova prismáticos para ensaio de flexão (um de cada placa), com o objetivo de determinar o módulo de ruptura. Das seis 
vigas, uma foi submetida a ensaio estático e cinco a ensaio de fadiga. Para os ensaios de placa, foi adotada freqüência entre 1 e $2 \mathrm{~Hz}$, sem períodos de folga. A tensão mínima era igual a 10\% da tensão máxima. A menor intensidade da tensão máxima adotada foi de $60 \%$ da resistência estática.

Antes de ensaiar as placas, Roesler realizou prova de carga estática na camada de argila, para determinar o coeficiente de reação.

\subsubsection{DISCUSSÃO DOS RESULTADOS}

Dos ensaios em vigas simplesmente apoiadas, Roesler verificou que a flecha apresenta uma grande parcela de deformação permanente (microfissuração e fluência), o que torna difícil o cálculo de tensões elásticas.

Os ensaios mostraram que a curva $\mathrm{S}-\mathrm{N}$ das vigas uniformemente apoiadas são semelhantes às das vigas simplesmente apoiadas. Portanto, não há razão para ensaios dinâmicos em vigas uniformemente apoiadas quando se deseja estudar pavimentos. O uso das vigas uniformemente apoiadas mostrou-se adequado em ensaios estáticos, para determinação do módulo de ruptura, ou resistência à tração na flexão, do concreto.

Os ensaios estáticos em placas uniformemente apoiadas resultaram em tensões de ruptura maiores que nas vigas simplesmente apoiadas. Isto significa que o módulo de ruptura das placas e das vigas não é o mesmo. Isso se deve à capacidade de redistribuição de tensões, à capacidade de deformação plástica adicional, à diferença do carregamento e às condições de contorno das placas. Tanto os ensaios estáticos como os dinâmicos mostraram que as placas não se comportam como os elementos lineares. Seu comportamento é mais elastoplástico.

A resistência à fadiga das placas uniformemente apoiadas foi cerca de $30 \%$ maior que das vigas, quando as intensidades de tensão foram calculadas por meio do módulo de ruptura das vigas simplesmente apoiadas. Considerou-se como ruína da placa o instante em que se formava uma charneira plástica onde a placa não podia mais resistir às ações. 
Em virtude da rápida deformação plástica e à fissuração do concreto, não foi possível utilizar os extensômetros para determinação das tensões de tração, mas serviram para indicar as áreas de altas deformações no plano de fissuração.

Na figura 4.12 são desenhadas as curvas S-N obtidas para as vigas simplesmente apoiadas, para as vigas uniformemente apoiadas e para as placas uniformemente apoiadas. Para traçado dessas curvas foi utilizado o módulo de ruptura das vigas simplesmente apoiadas, para determinar as intensidades de tensão has vigas e nas placas. Nota-se que as curvas são essencialmente paralelas, o que indica que os três sistemas têm comportamento similar, podendo ser aplicado um fator de escala. Esse fator pode ser resultado de uma interpretação errada da resistência do concreto à flexão nas placas e do uso da teoria da elasticidade para descrever a ruptura por fadiga.

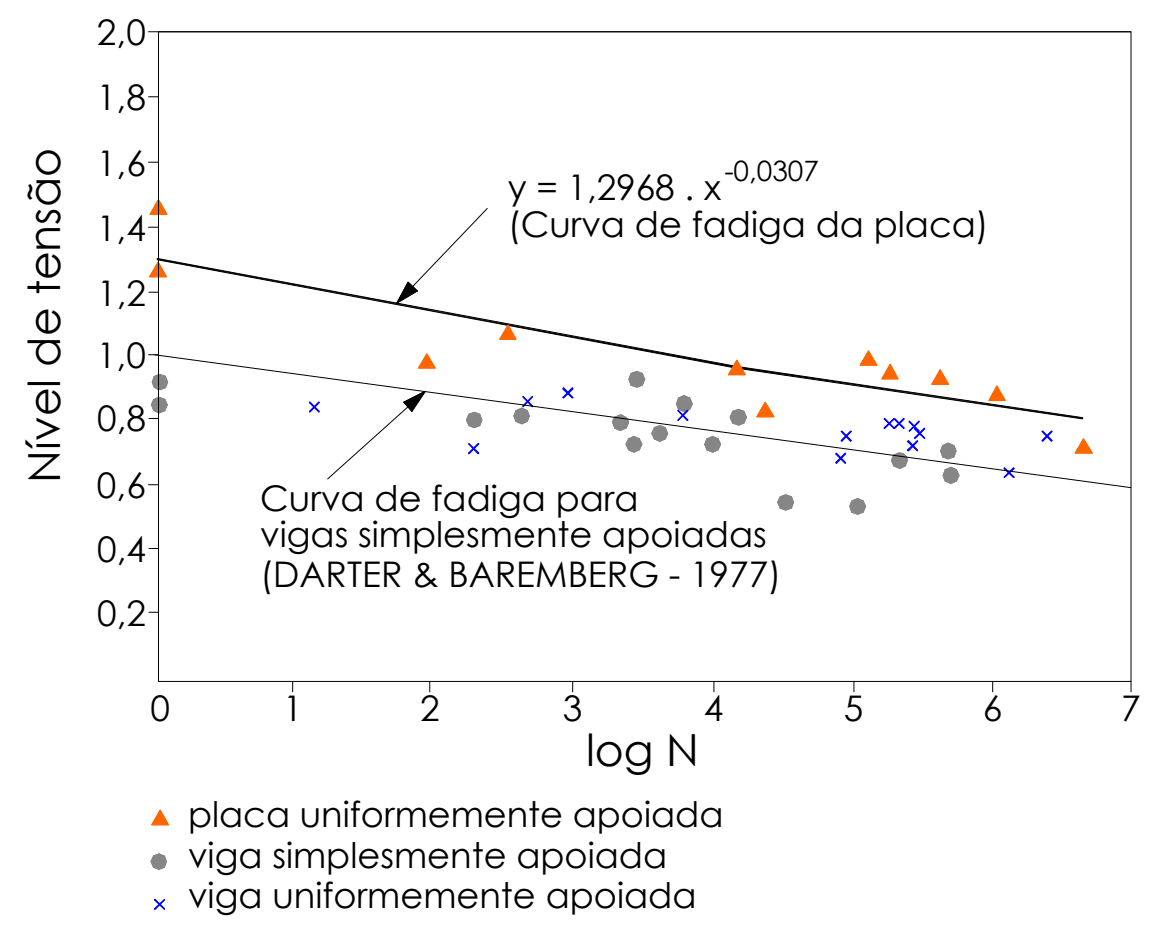

Figura 4.12 - Curvas S-N obtidas por Roesler (1998) para os três modelos

Se for usado o módulo de ruptura das placas para determinação das suas intensidades de tensão, as curvas para os três modelos são praticamente coincidentes. Portanto, o fator de escala citado anteriormente pode ser determinado pela relação entre o módulo de ruptura das placas e o módulo de ruptura das vigas, determinados em ensaios estáticos. Conclui-se que se for utilizado o módulo de ruptura adequado, o comportamento do concreto à fadiga não depende da forma do modelo. 
Nos ensaios de Roesler não foram considerados os efeitos do empenamento, da retração e das tensões de cisalhamento.

Quanto à fissuração, Roesler observou que as vigas não admitem mais de uma direção de propagação de fissuras e que a única fissura visual que aparece na face superior é a que provoca a ruína da peça, separando-a em duas partes. Nas vigas as fissuras são bem localizadas.

A formação e propagação de fissuras nas placas foram semelhantes às das vigas. O início da fissuração ocorria logo após os primeiros ciclos. Os extensômetros indicaram a propagação das fissuras na face inferior antes de atingir a superfície. A partir de uma certa abertura, era possível visualizar fissuras nas laterais das placas. A propagação da fissura em planta e na espessura da placa levava à ruína.

Nesse trabalho a ruína foi definida quando o modelo perdia a capacidade de transferir esforços através da fissura. Essa situação refere-se à charneira plástica citada anteriormente.

As diferenças nas definições da ruína tornam difícil a comparação dos resultados de laboratório com os resultados de campo.

Segundo Roesler, a curva S-N pode não ser a melhor maneira de descrever a ruína por fadiga, mas é a melhor maneira de quantificar a resistência do concreto submetido a ações cíclicas. As curvas S-N são extremamente sensíveis às variações das intensidades de tensão. Portanto, um erro de 10\%, por exemplo, no cálculo dessas intensidades, implicaria em erros significativos no número admissível de repetições. O conceito de intensidade de tensão assume que a placa é carregada elasticamente a uma mesma intensidade de tensão em todos os ciclos de ensaio, mas, na verdade, a plastificação do material ocorre cedo, por causa da fissuração.

\subsection{RODRIGUES (2003)}

Rodrigues (2003) realizou ensaios estáticos em dez placas quadradas, isoladas, de concreto simples e de concreto armado, apoiadas sobre base granular de $20 \mathrm{~cm}$ de espessura, com força aplicada no interior e na borda. O objetivo era estudar o 
comportamento estrutural dessas placas, dando especial atenção à espessura de concreto, à taxa de armadura e à posição do carregamento.

Os ensaios foram divididos em dois grupos: o primeiro inclui quatro placas de $300 \mathrm{~cm} \times 300 \mathrm{~cm} \times 10 \mathrm{~cm}$, e o segundo, seis placas de $100 \mathrm{~cm} \times 100 \mathrm{~cm} \times$ $3,4 \mathrm{~cm}$.

\subsubsection{MetOdOLOGIA DE ENSAIO}

Os modelos foram ensaiados até a ruptura, definida pelo instante em que a placa apresenta fissura na superfície superior.

Na tabela 4.2 apresenta-se a descrição dos modelos ensaiados.

Tabela 4.2 - Geometria dos modelos (Rodrigues - 2003)

\begin{tabular}{cccccc}
\hline Modelo & Lado $(\mathrm{cm})$ & $\begin{array}{c}\text { Espessura } \\
(\mathrm{cm})\end{array}$ & $\begin{array}{c}\text { Taxa de } \\
\text { armadura } \\
\text { inferior (\%) }\end{array}$ & $\begin{array}{c}\text { Taxa de } \\
\text { armadura } \\
\text { superior }(\%)\end{array}$ & $\begin{array}{c}\text { Posição da } \\
\text { força }\end{array}$ \\
\hline P1 & 300 & 10 & - & - & centro \\
P2 & 300 & 10 & - & - & borda \\
P3 & 300 & 10 & 0,284 & - & centro \\
P4 & 300 & 10 & 0,284 & - & borda \\
P1A & 100 & 3,4 & - & - & centro \\
P2A & 100 & 3,4 & - & - & borda \\
P3A & 100 & 3,4 & 0,179 & - & centro \\
P4A & 100 & 3,4 & 0,179 & - & borda \\
P3B & 100 & 3,4 & 0,179 & 0,107 & centro \\
P4B & 100 & 3,4 & 0,179 & 0,107 & borda \\
\hline
\end{tabular}

Os modelos foram concretados no local de ensaio, sobre a base granular. Foi posicionada uma lona plástica entre a camada de areia e o concreto.

Os deslocamentos verticais da placa foram medidos com auxílio de deflectômetros, posicionados nos cantos, nas diagonais e nas medianas das placas. As deformações no aço e no concreto foram medidas por extensômetros elétricos, posicionados ao longo das diagonais e das medianas das placas das placas P1 a P4.

O esquema de ensaio está apresentado na figura 4.13. 


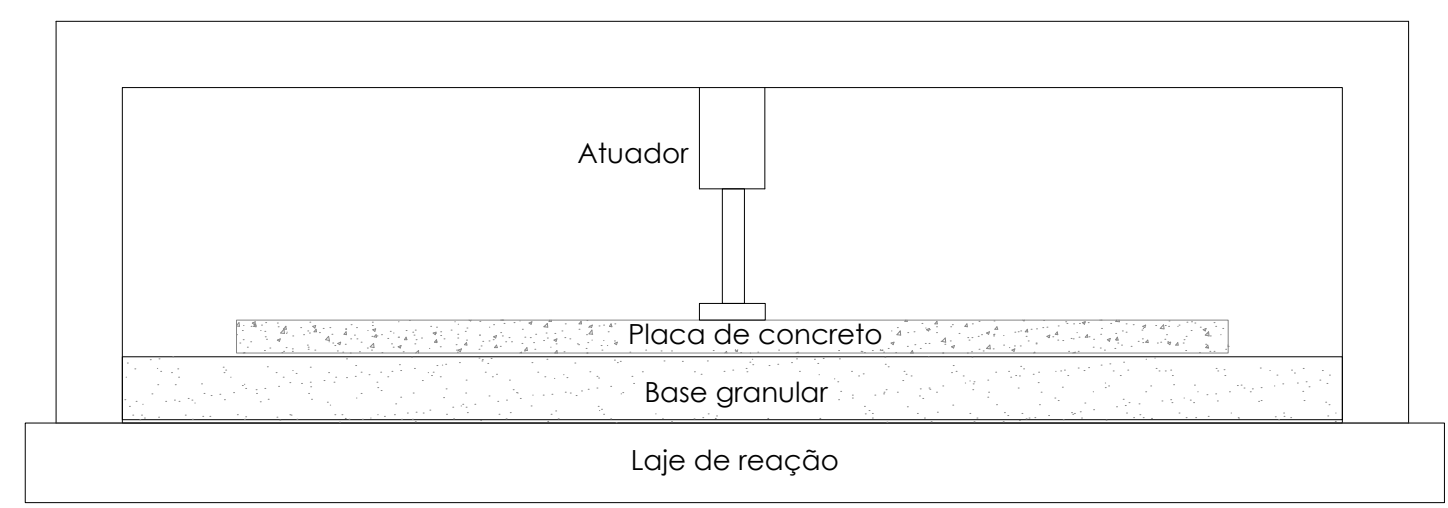

Figura 4.13 - Esquema de ensaio - Rodrigues (2003)

A força foi aplicada numa área de $20 \mathrm{~cm} \times 30 \mathrm{~cm}$, nos modelos de $300 \mathrm{~cm}$ de lado, e numa área de $7 \mathrm{~cm} \times 10 \mathrm{~cm}$, nos modelos de $100 \mathrm{~cm}$ de lado.

\subsubsection{DISCUSSÃO DOS RESULTADOS}

Na tabela 4.3 apresentam-se as forças de fissuração e de ruína, dos modelos ensaiados.

Tabela 4.3 - Resultados de força última - Rodrigues (2003)

\begin{tabular}{cc}
\hline Modelo & Força de ruína $(\mathrm{kN})$ \\
\hline P1 & 220 \\
P3 & 655 \\
P1A & 12,8 \\
P3A & 25,9 \\
P3B & 24,8 \\
P2 & 70 \\
P4 & 226 \\
P2A & 11,5 \\
P4A & 8 \\
P4B & 7 \\
\hline
\end{tabular}

A primeira fissura do modelo P3, de concreto armado, apareceu com a força de aproximadamente 200 kN, valor próximo da ruína da placa Pl, de concreto simples.

Observa-se um grande ganho de resistência com, a adição de armadura próxima à face inferior das placas. O acréscimo da armadura superior não contribuiu na resistência da placa às forças verticais. Segundo Rodrigues (2003), este tímido desempenho pareceu ser em virtude das condições desfavoráveis do espaçamento vertical das armaduras positivas e negativas, na ordem de $13 \mathrm{~mm}$, além de dificuldades de execução do ensaio. A autora ressalta que, na prática, deve existir ganho de resistência da peça com armadura dupla. Contudo, a semelhança no comportamento indicou a boa representatividade de uma peça 
com dimensões de $100 \mathrm{~cm} \times 100 \mathrm{~cm}$ x 3,4 cm em relação a uma com dimensões proporcionais superiores, para as mesmas condições de carregamento e propriedades da fundação.

Observando as fissuras dos modelos, Rodrigues (2003) conclui que a ruína das placas de concreto simples ocorreu por flexão. Nas placas de concreto armado, foram observadas fissuras radiais e circunferenciais. Em geral, nas placas de concreto armado, a primeira fissura a aparecer na face superior era a circunferencial. As fissuras radiais se desenvolviam na face inferior e se tornavam visíveis na face superior já no final do ensaio, crescendo no sentido do centro para as bordas.

\subsection{CONSIDERAÇÕES FINAIS}

Neste capítulo foram apresentadas metodologias de ensaios em placas para estudo de pavimentos de concreto. Estes trabalhos serviram como base para 0 projeto do programa experimental que é descrito no capítulo 5. 



\section{MODELAGEM EXPERIMENTAL}

O estudo experimental foi dividido em três etapas:

- la etapa - ensaios estáticos e de fadiga em vigas armadas com telas soldadas

- 2a etapa - ensaios estáticos, com controle de deslocamento, em vigas de concreto simples e de concreto armado com telas soldadas

- 3a etapa - ensaios com carregamentos estáticos e repetidos em placas de concreto simples e de concreto armado apoiadas sobre base elástica.

A seguir será descrita a metodologia adotada e apresentados os resultados obtidos da modelagem experimental.

5. 1 PRIMEIRA ETAPA

Nesta etapa foram realizados ensaios de flexão em vigas de concreto armadas com tela soldada, com os objetivos de determinar o momento fletor último das vigas submetidas a carregamento estático, verificar a resistência à fadiga da tela soldada e acompanhar a evolução das deformações no aço, no decorrer do carregamento repetido. Com a finalidade de adequar os ensaios ao cronograma do laboratório o tempo de execução de cada um foi restringido, adotando forças repetidas elevadas, que provocam um número reduzido de repetições

Os ensaios das vigas foram divididos em duas séries:

- Série Q196 - vigas armadas com tela de $1,96 \mathrm{~cm}^{2} / \mathrm{m}$ e $\phi$ de $5 \mathrm{~mm}$, espaçamento de $10 \mathrm{~cm}$

- Série Q283 - vigas armadas com tela de $2,83 \mathrm{~cm}^{2} / \mathrm{m}$ e $\phi$ de $6 \mathrm{~mm}$, espaçamento de $10 \mathrm{~cm}$ 


\subsubsection{GEOMETRIA}

Os principais parâmetros geométricos das vigas estão apresentados na tabela 5.1.

Tabela 5.1 - Parâmetros geométricos das vigas

\begin{tabular}{ccc}
\hline Parâmetro & Q196 & Q283 \\
\hline Comprimento $(\mathrm{cm})$ & $70 \mathrm{~cm}$ & $70 \mathrm{~cm}$ \\
Vão $(\mathrm{cm})$ & $60 \mathrm{~cm}$ & $60 \mathrm{~cm}$ \\
Largura $(\mathrm{cm})$ & $30 \mathrm{~cm}$ & $30 \mathrm{~cm}$ \\
Altura $(\mathrm{cm})$ & $14 \mathrm{~cm}$ & $14 \mathrm{~cm}$ \\
Cobrimento $(\mathrm{cm})$ & $4 \mathrm{~cm}$ & $4 \mathrm{~cm}$ \\
Altura útil $(\mathrm{cm})$ & $9,75 \mathrm{~cm}$ & $9,7 \mathrm{~cm}$ \\
Área de aço $\left(\mathrm{cm}^{2}\right)$ & $0,588 \mathrm{~cm}^{2}$ & $0,849 \mathrm{~cm}^{2}$ \\
$\phi(\mathrm{mm})$ & 5,0 & 6,0 \\
Espaçamento entre fios & $10 \mathrm{~cm}$ & $10 \mathrm{~cm}$ \\
Taxa de armadura (\%) & 0,14 & 0,20 \\
\hline
\end{tabular}

A altura de $14 \mathrm{~cm}$ é um valor comum na construção de pavimentos de concreto estruturalmente armados, para tráfego intenso.

A largura de $30 \mathrm{~cm}$ foi adotada com o objetivo de possibilitar a colocação de tela soldada com três fios longitudinais, visto que a distância entre os fios é de $10 \mathrm{~cm}$. Considerando as condições da máquina de ensaios adotou-se o vão de $60 \mathrm{~cm}$.

O sistema de apoio consiste em dois cilindros que podem ser posicionados a distâncias entre 45 e $60 \mathrm{~cm}$ um do outro. Para aplicação da força utilizou-se uma placa onde são fixados dois cilindros cuja distância pode variar entre 15 e $20 \mathrm{~cm}$. A ligação entre esta placa e o atuador é realizada por meio de uma rótula.

\subsubsection{PREPARAÇÃO DOS MODELOS}

Para a série Q196 foram moldados três modelos ensaiados com carregamento monotônico e seis com carregamento repetido. Para a série Q283 foram utilizados dois modelos para ensaio com carregamento monotônico e cinco para carregamento repetido.

Na figura 5.1 é mostrada uma fôrma para seis vigas, com as telas posicionadas, pronta para receber $\bigcirc$ concreto. Para garantir $\bigcirc$ cobrimento de $4 \mathrm{~cm}$ foram utilizados caranguejos de aço e as telas foram amarradas à fôrma com arame recozido. 
A concretagem foi realizada com concreto usinado, o qual foi solicitado com resistência de $30 \mathrm{MPa}$ e brita no 1. A figura 5.2 mostra a fôrma sobre a mesa vibratória, logo após a concretagem.

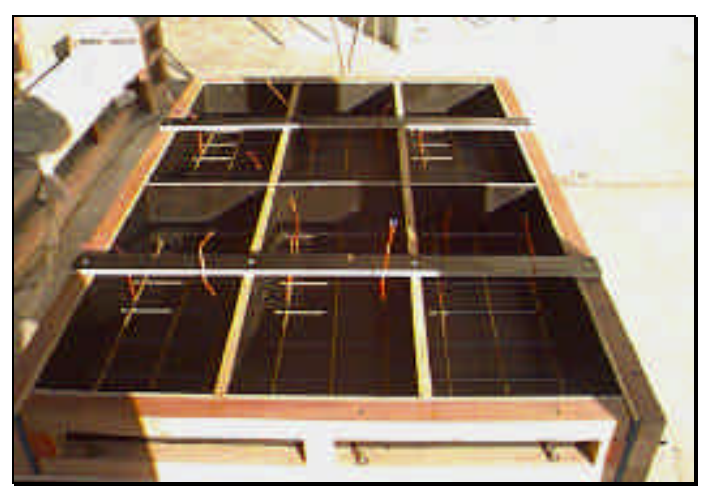

Figura 5.1 - Posicionamento da armadura

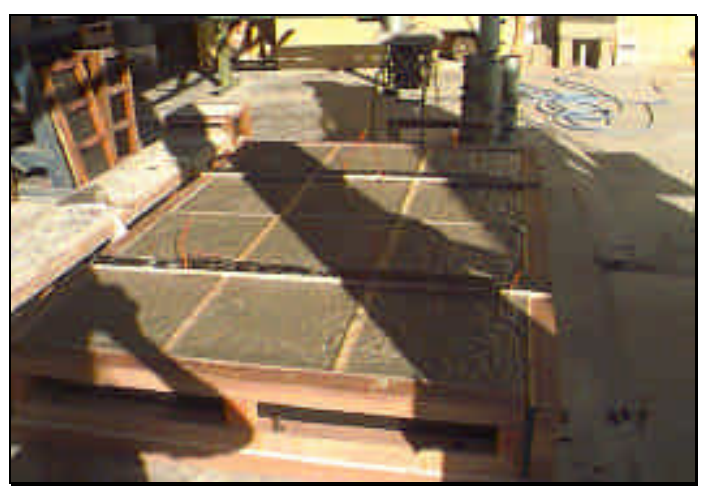

Figura 5.2 - Fôrma para seis vigas, sobre a mesa vibratória

Foram moldados ainda doze corpos-de-prova cilíndricos de $15 \mathrm{~cm} \times 30 \mathrm{~cm}$, para verificação da resistência do concreto, nas datas de realização dos ensaios. A concretagem foi realizada com antecedência a fim de se obter uma resistência estável que não afetasse os ensaios à fadiga.

\subsubsection{ESQUEMA GERAL DO ENSAIO E INSTRUMENTAÇÃO}

Os ensaios foram realizados no Laboratório de Rochas do Departamento de Geotecnia da EESC. Foi utilizado Sistema para ensaio de cisalhamento da MTS, que permite a realização de ensaios dinâmicos. A figura 5.3 representa o esquema do ensaio.

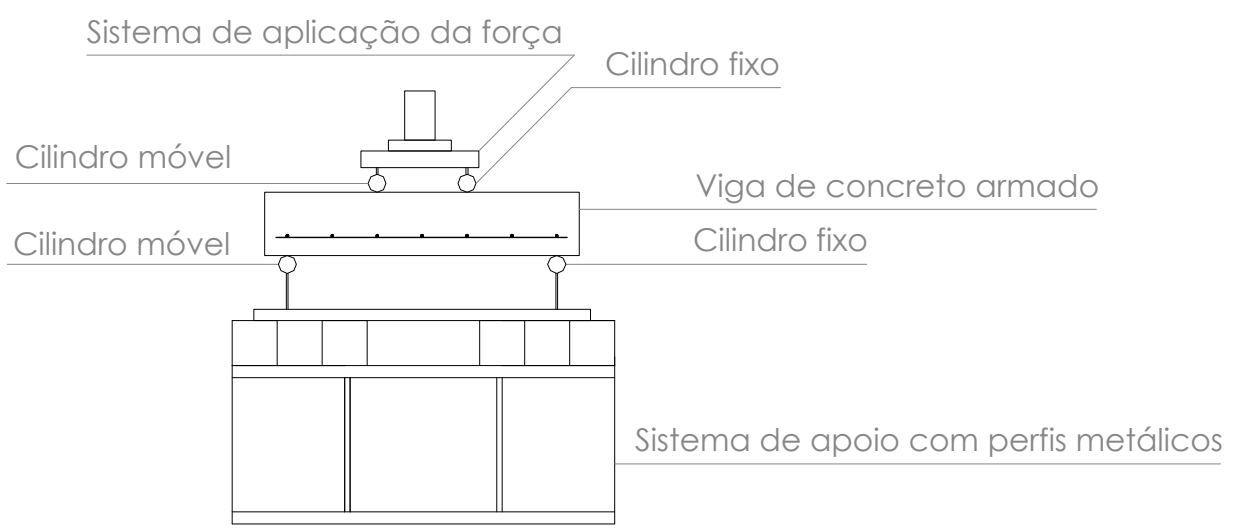

Figura 5.3 - Sistema de ensaio de flexão de vigas 
As vigas eram biapoiadas, com aplicação das forças nos terços do vão, conforme ilustrado na figura 5.3. Adotando essa configuração obtém-se uma região, entre os pontos de aplicação das forças, com curvatura e momento fletor constantes.

Foram colados dois extensômetros em cada uma das armaduras dos modelos, conforme indicado na figura 5.4, e um extensômetro centralizado na face superior de cada viga, como pode ser visto na figura 5.5.

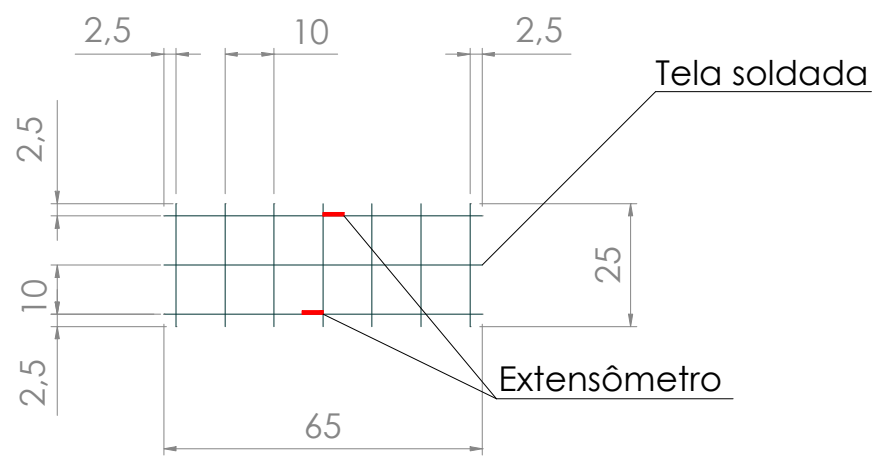

Figura 5.4 - Posicionamento dos extensômetros na armadura

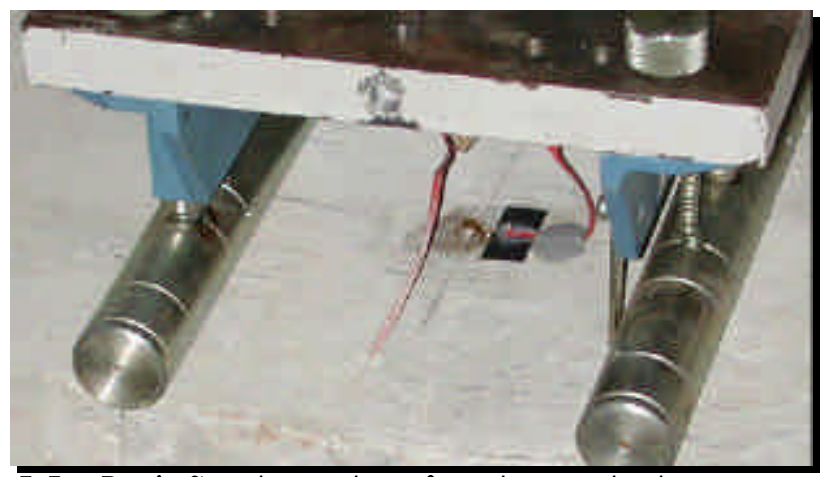

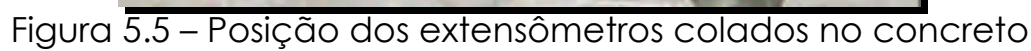

Na figura 5.6 é mostrada a viga posicionada no equipamento.

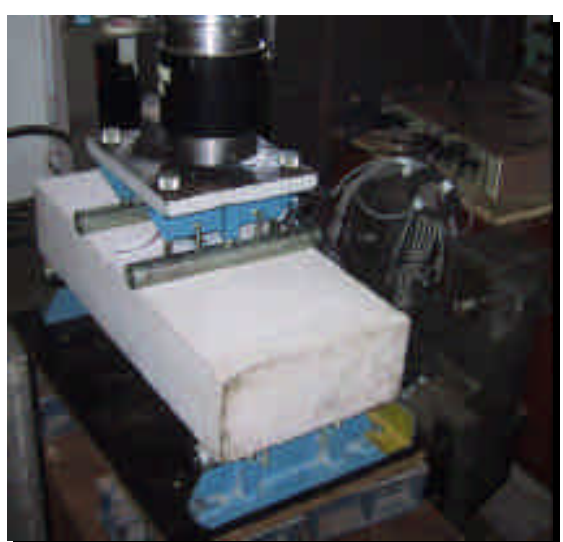

Figura 5.6 - Posicionamento das vigas da primeira etapa 


\subsubsection{RESULTADOS}

O ensaio de resistência à compressão do concreto foi realizado aos 226 dias. Com essa idade a resistência já pode ser considerada constante. Os valores obtidos estão apresentados na tabela 5.2.

Tabela 5.2 - Resistência à compressão

\begin{tabular}{cccc}
\hline $\mathrm{CP}$ & Idade do CP (dias) & $\mathrm{f}_{\mathrm{c}}\left(\mathrm{kN} / \mathrm{cm}^{2}\right)$ & $\mathrm{f}_{\mathrm{c}}(\mathrm{MPa})$ \\
\hline 1 & 226 & 5,14 & 51,36 \\
2 & 226 & 5,04 & 50,40 \\
3 & 226 & 5,12 & 51,19 \\
Média & & 5,10 & 50,98 \\
\hline
\end{tabular}

O ensaio para determinação do módulo de elasticidade também foi realizado aos 226 dias. Os gráficos tensão-deformação estão apresentados na figura 5.7.

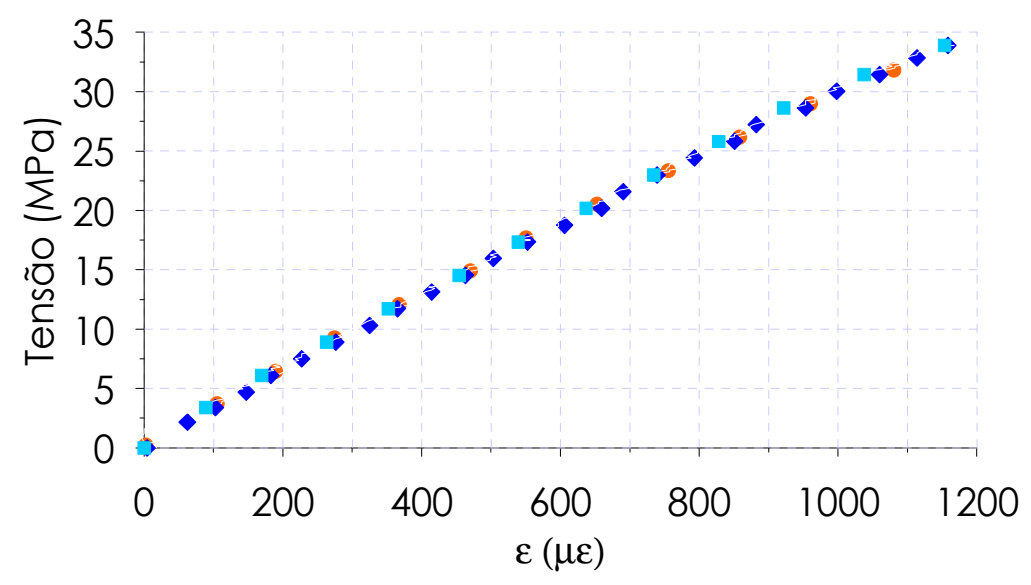

Figura 5.7 - Diagrama tensão-deformação, de módulo de elasticidade

Pode-se calcular que o módulo de elasticidade tangente é de 29145 MPa.

a. Série Q196

\section{Ensaios estáticos}

Os resultados obtidos da flexão das vigas sob carregamento monotônico estão resumidos na tabela 5.3 .

Tabela 5.3 - Resumo dos resultados dos ensaios estáticos da série Q196

\begin{tabular}{ccccc}
\hline & Viga 1 & Viga 2 & Viga 3 & Média \\
\hline $\begin{array}{c}\text { Força de fissuração } \\
\text { (kN) }\end{array}$ & 44,40 & 43,23 & 43,42 & 43,68 \\
$\begin{array}{c}\text { Deformação média no aço no } \\
\text { instante da fissuração (\%o) }\end{array}$ & 0,5490 & 0,2020 & 0,3245 & 0,3585 \\
$\begin{array}{c}\text { Deformação no concreto no } \\
\text { instante da fissuração (\%) }\end{array}$ & $-0,2460$ & $-0,1970$ & $-0,1179$ & $-0,1870$ \\
\hline
\end{tabular}




\begin{tabular}{ccccc}
\hline & Viga 1 & Viga 2 & Viga 3 & Média \\
\hline $\begin{array}{c}\text { Força de ruptura } \\
\text { (kN) }\end{array}$ & 48,22 & 48,24 & 48,23 & 48,23 \\
$\begin{array}{c}\text { Deformação média no aço no } \\
\text { instante da ruptura (\%) }\end{array}$ & 12,9510 & 10,7210 & 12,5490 & 12,0737 \\
$\begin{array}{c}\text { Deformação no concreto no } \\
\text { instante da ruptura (\%) }\end{array}$ & $-1,4390$ & $-1,4110$ & $-1,0860$ & $-1,3120$ \\
\hline
\end{tabular}

A figura 5.8 mostra a ruína da primeira viga submetida a ação estática.

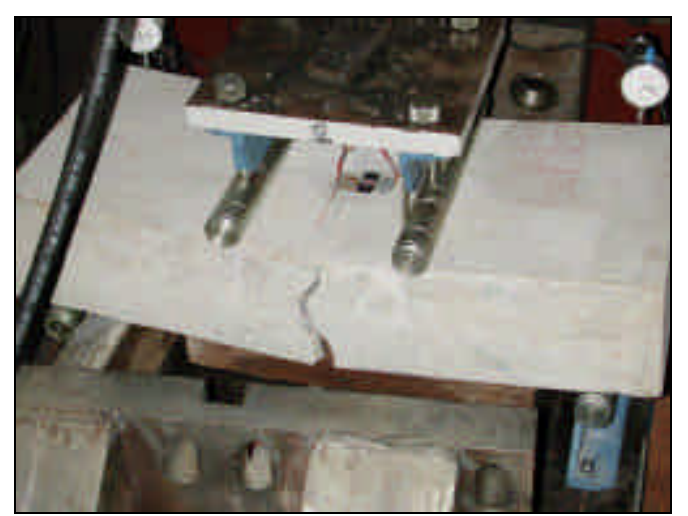

Nas vigas armadas com tela Q196

ocorria a formação de apenas uma

fissura, dentro do terço central da viga,

que ao aumentar sua abertura

provocava deformação excessiva do

aço e a viga acabava se dividindo em

duas partes.

Figura 5.8 - Viga rompida sob

carregamento estático

\section{Ensaios de fadiga}

No primeiro ensaio cíclico procurou-se aplicar uma força máxima igual a $90 \%$ da força última, que corresponde a $43,41 \mathrm{kN}$ e com a força mínima próxima de zero. Porém o equipamento não permite a aplicação de forças tão reduzidas e a força mínima ficou em 8,03 kN - 17\% da força última. Portanto a diferença entre a força mínima e a máxima foi de 73\%. A freqüência aplicada foi de $1 \mathrm{~Hz}$. Chegou-se a 6140 ciclos, observando que a fissuração do concreto ocorreu logo no primeiro ciclo. O ensaio foi interrompido por causa do término do expediente do laboratório. No dia seguinte foi retomado o ensaio. Mudando algumas configurações do equipamento, foi obtida uma força mínima de 4,3 kN e máxima de $42,29 \mathrm{kN}$, correspondendo a $9 \%$ e $88 \%$, respectivamente. Desta forma $\mathrm{O}$ intervalo de força foi de $79 \%$. A fim de acelerar o término do ensaio, adotou-se então uma freqüência de $5 \mathrm{~Hz}$. A ruína ocorreu após a aplicação de mais 1978 ciclos. No total foram necessários 6800 ciclos para a viga atingir o colapso por fadiga.

Por causa dos problemas no primeiro ensaio, foi repetido o ensaio com $90 \%$ da força. Foram aplicados cerca de 20 ciclos com força entre $8 \mathrm{kN}$ e $34 \mathrm{kN}$, com freqüência de $0,5 \mathrm{~Hz}$. Mudou-se a freqüência para $5 \mathrm{~Hz}$ e aplicou-se 1000 ciclos com força entre $4,3 \mathrm{kN}$ e $42,5 \mathrm{kN}$. Voltou-se para a freqüência de $0,5 \mathrm{~Hz}$ e força 
entre 1,7 kN e $43 \mathrm{kN}$, deixando aproximadamente 20 ciclos. Voltou-se para $5 \mathrm{~Hz}$, intervalo entre 1,7 kN e 42,5 kN. A viga rompeu com 1445 ciclos. Nos períodos de frequência de $0,5 \mathrm{~Hz}$ era acionado o sistema de aquisição de dados a fim de armazenar os valores de força e deformações.

No terceiro ensaio procurou-se atingir $80 \%$ da força de ruína. Foram aplicados cerca de 20 ciclos com freqüência de $0,5 \mathrm{~Hz}$. Mudou-se para $5 \mathrm{~Hz}$ e força entre $3,3 \mathrm{kN}$ e $37,7 \mathrm{kN}$. A cada 1000 ciclos baixou-se a freqüência para 0,5 Hz, com força de 1,43 kN a 38,52 kN. Fez-se isso até aproximadamente 11000 ciclos. Depois as leituras foram realizadas aos 20500, 25000, 30000, 35000, 40000, 45000. A viga foi a colapso com 45990 ciclos.

No quarto ensaio de fadiga repetiu-se a força máxima de $80 \%$ da força última. Adotou-se o mesmo procedimento do ensaio anterior, fazendo leituras quando a frequência era de $0,5 \mathrm{~Hz}$ e intercalando com frequências de $5 \mathrm{~Hz}$. As leituras foram efetuadas no início, a cada 1000 ciclos até os 10000 ciclos e depois aos 15000 ciclos. As forças para frequência de $0,5 \mathrm{~Hz}$ foram de 1,79 kN e 39,99 kN e, para $5 \mathrm{~Hz}, 1,79 \mathrm{kN}$ e 40,01 kN. A fisuração do concreto ocorreu entre 400 e 600 ciclos e a ruína da viga aos 16583 ciclos.

Nos dois modelos seguintes buscou-se aplicar força máxima de $70 \%$, seguindo 0 mesmo procedimento dos ensaios anteriores. As forças obtidas estão apresentadas na tabela 5.4, onde se encontra um resumo dos resultados dos ensaios de fadiga da série Q196.

Tabela 5.4 - Resumo dos ensaios de fadiga da série Q196

\begin{tabular}{ccccccc}
\hline Modelo & Q196A & Q196B & Q196C & Q196D & Q196E & Q196F \\
\hline$F_{\max }(\mathrm{kN})-0,5 \mathrm{~Hz}$ & & 43,00 & 38,52 & 39,99 & 34,80 & 34,82 \\
$F_{\min }(\mathrm{kN})-0,5 \mathrm{~Hz}$ & & 1,70 & 1,43 & 1,79 & 1,40 & 1,40 \\
$F_{\max }(\mathrm{kN})-5 \mathrm{~Hz}$ & & 42,50 & 37,70 & 40,01 & 34,00 & 34,00 \\
$F_{\min }(\mathrm{kN})-5 \mathrm{~Hz}$ & & 4,30 & 3,30 & 1,79 & 3,23 & 3,23 \\
$F_{\max }-F_{\min }(\mathrm{kN})-5 \mathrm{~Hz}$ & & 38,20 & 34,40 & 38,22 & 30,70 & 30,77 \\
$F_{\max }-F_{\min }(\%)-5 \mathrm{~Hz}$ & & 79,20 & 71,30 & 79,20 & 63,80 & 63,80 \\
No ciclos 1a fissura & 1 & - & 500 & 2500 & 2500 \\
No ciclos na ruína & 8118 & 1445 & 45990 & 16583 & 74151 & 101302 \\
\hline
\end{tabular}

A configuração de ruptura das vigas da série Q196 submetidas à fadiga foi semelhante às das vigas submetidas a carregamento monotônico. Houve a formação de uma única fissura dentro do terço central do vão, a qual crescia com a repetição do carregamento. 
b. Série Q283

\section{Ensaios estáticos}

Os resultados obtidos dos ensaios estáticos da série Q283 estão apresentados na tabela 5.5 .

Tabela 5.5 - Resumo dos resultados dos ensaios estáticos da série Q283

\begin{tabular}{cccc}
\hline & Viga 1 & Viga 2 & Média \\
\hline $\begin{array}{c}\text { Força de fissuração } \\
\text { (kN) }\end{array}$ & 41,01 & 39,93 & 40,47 \\
$\begin{array}{c}\text { Deformação média no aço no } \\
\text { instante da fissuração (\%o) }\end{array}$ & 0,168 & 0,207 & 0,188 \\
$\begin{array}{c}\text { Deformação no concreto no } \\
\text { instante da fissuração (\%०) }\end{array}$ & - & $-0,515$ & - \\
$\quad \begin{array}{c}\text { Força de ruptura } \\
\text { (kN) }\end{array}$ & 60,63 & 63,85 & 62,24 \\
$\begin{array}{c}\text { Deformação média no aço no } \\
\text { instante da ruptura (\%) }\end{array}$ & - & 12,685 & - \\
$\begin{array}{c}\text { Deformação no concreto no } \\
\text { instante da ruptura (\%०) }\end{array}$ & - & $-3,167$ & - \\
\hline
\end{tabular}

A figura 5.9 mostra a ruptura da primeira viga da série Q283 submetido a ação estática. Nos ensaios da série Q283 houve a formação de três fissuras no concreto, antes da ruptura total da peça. Nas figuras 5.10, 5.11 e 5.12 é mostrada a seqüência de aparecimento dessas fissuras, na segunda viga sob carregamento estático. A ruína é mostrada na figura 5.13.

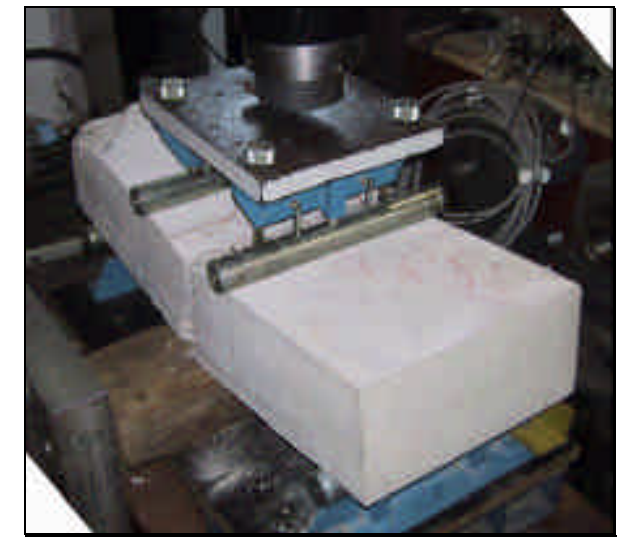

Figura 5.9 - Primeira viga da série Q283 rompida sob ação estática

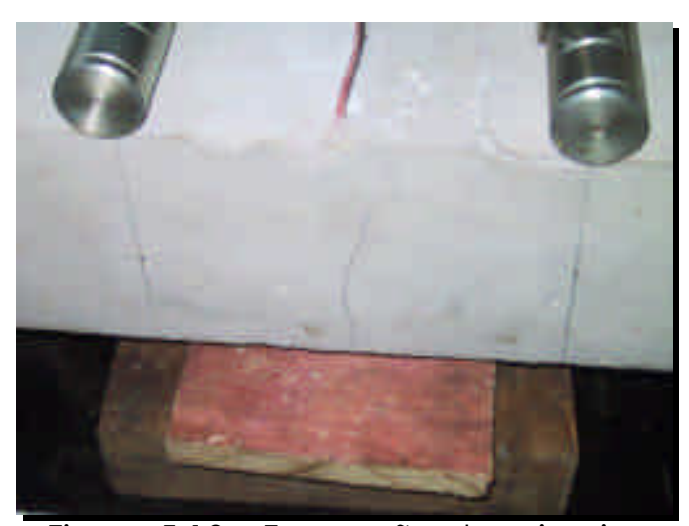

Figura 5.10 - Formação da primeira fissura no ensaio estático da série Q283 


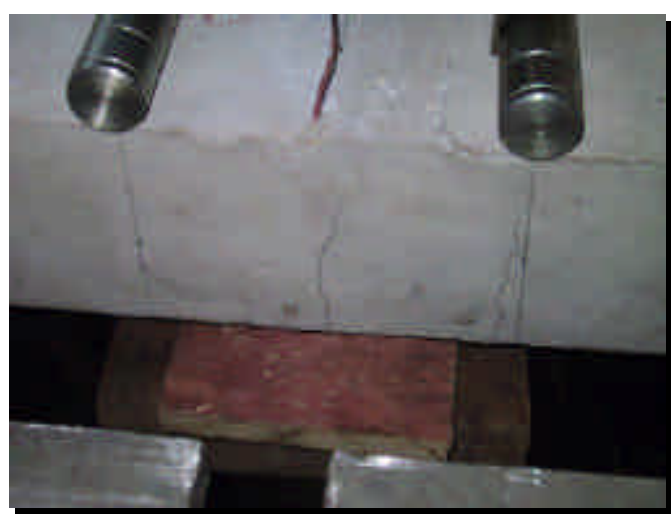

Figura 5.11 - Formação da segunda fissura no ensaio estático da série Q283, à direita

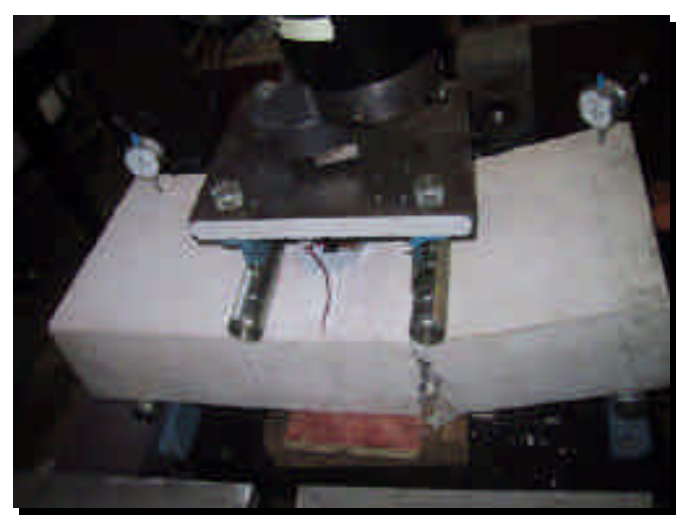

Figura 5.13 - Ruína de uma das vigas da série Q283, sob ação estática

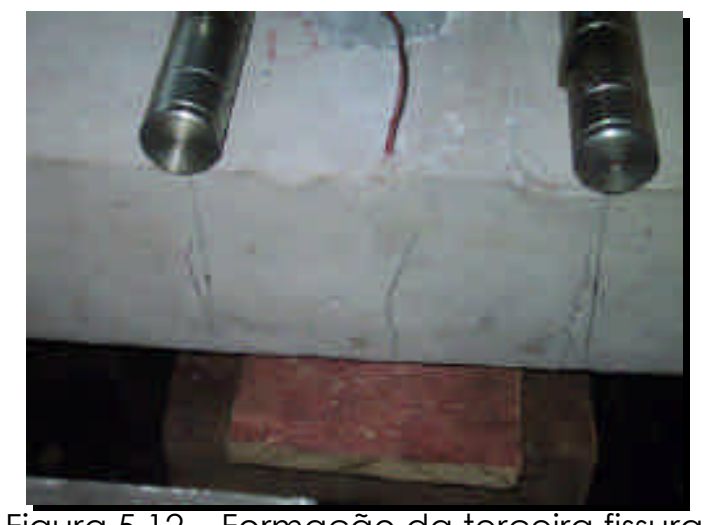

Figura 5.12 - Formação da terceira fissura no ensaio estático da série Q283,

à esquerda

No caso das vigas da série Q283, a taxa de armadura mais alta proporcionou a abertura de três fissuras dentro do terço central da viga, antes que houvesse a deformação excessiva da armadura e a viga se dividisse em duas partes.

\section{Ensaios de fadiga}

No primeiro ensaio de fadiga da série Q283 procurou-se atingir a força máxima de 90\% da força última. Foram aplicados, inicialmente, cerca de 20 ciclos com freqüência de $0,5 \mathrm{~Hz}$, com a força variando entre 1,77 kN e 56,79 kN. Mudou-se para $5 \mathrm{~Hz}$ e as forças mínimas e máximas de 2,70 kN e 55,14 kN. A redução da freqüência e a leitura dos dados foram efetuadas nos 600, 1200, 2002, 3000 e 4000 ciclos. A ruptura final ocorreu aos 4646 ciclos.

No modelo seguinte procurou-se atingir novamente a força máxima de $90 \%$ da força última. Para a freqüência de $0,5 \mathrm{~Hz}$, aplicaram-se forças máxima e mínima de $58,34 \mathrm{kN}$ e $1,90 \mathrm{kN}$, respectivamente. Para a freqüência de $5 \mathrm{~Hz}$ as forças foram de $55,08 \mathrm{kN}$ e 1,33 kN. As leituras foram efetuadas no início e a cada 1000 ciclos. A primeira fissura apareceu no primeiro ciclo. A ruína ocorreu aos 6867 ciclos.

Nos ensaios de fadiga da série Q283, com 90\% da força última, também houve a formação de três fissuras (figura 5.14) antes da ruína da viga (figura 5.15). 


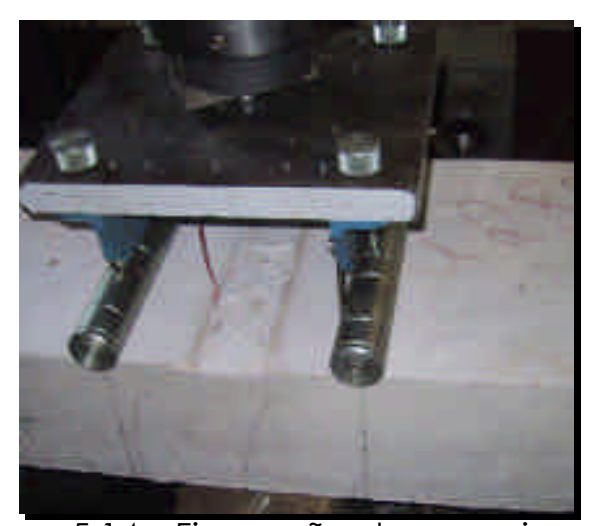

Figura 5.14 - Fissuração de uma viga da série Q283 submetida a carregamento repetido $-90 \%$

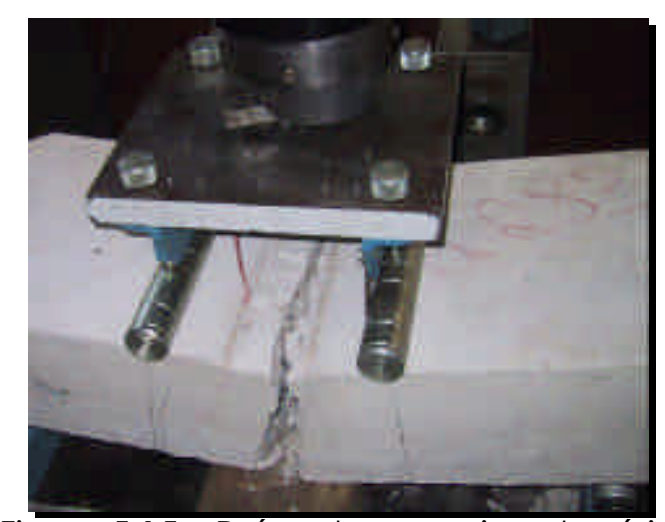

Figura 5.15 - Ruína de uma viga da série Q283 sob carregamento repetido - 90\%

No terceiro modelo procurou-se alcançar uma força máxima igual a $80 \%$ da força última. Para a freqüência de $0,5 \mathrm{~Hz}$, aplicaram-se forças máxima e mínima de $50,86 \mathrm{kN}$ e 1,70 kN, respectivamente. Para a freqüência de $5 \mathrm{~Hz}$ as forças foram de $50,85 \mathrm{kN}$ e 1,72 kN. As leituras foram efetuadas no início e a cada 1000 ciclos. A primeira fissura apareceu no terceiro ciclo. A segunda fissura se formou aproximadamente aos 3000 ciclos. Não houve a formação da terceira fissura e a ruína ocorreu aos 7749 ciclos.

No próximo modelo repetiu-se a força de $80 \%$ da força última. Para a freqüência de $5 \mathrm{~Hz}$ as forças foram de $49,69 \mathrm{kN}$ e 4,44 kN. A primeira fissura ocorreu no primeiro ciclo e a segunda no quinto ciclo. Não houve formação da terceira fissura. A ruína ocorreu aos 12984 ciclos. Não foi feita aquisição dos dados.

No último ensaio de fadiga da série procurou-se aplicar $70 \%$ da força última. Para a freqüência de $0,5 \mathrm{~Hz}$ as forças foram de $44,98 \mathrm{kN}$ e 1,8 kN. Na freqüência de $5 \mathrm{~Hz}$ foram aplicadas forças máxima e mínima de $43,80 \mathrm{kN}$ e 3,70 kN, respectivamente. As duas fissuras no concreto ocorreram no primeiro ciclo. As leituras foram efetuadas no início, a cada 1000 ciclos até os 10000 e de 5000 em 5000 ciclos até a ruína da peça, que ocorreu aos 60770 ciclos.

Nos ensaios com força máxima de até $80 \%$ da força ultimam houve a formação de apenas duas fissuras (figura 5.16) e uma delas se abre até a ruína. 


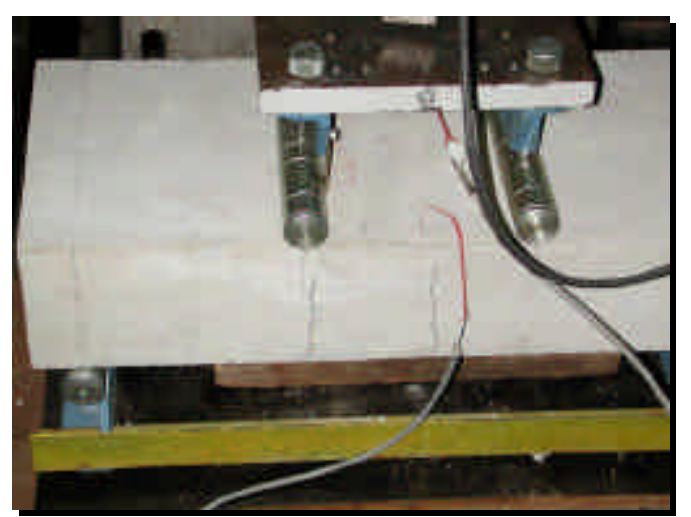

Figura 5.16 - Fissuração de uma viga da série Q283 submetida a carregamento repetido $-80 \%$

Na tabela 5.6 é apresentado um resumo dos resultados dos ensaios de fadiga da série Q283.

Tabela 5.6 - Resumo dos ensaios de fadiga da série Q283

\begin{tabular}{cccccc}
\hline Modelo & $Q 283 A$ & $Q 283 B$ & $Q 283 C$ & $Q 283 D$ & Q283E \\
\hline$F_{\max }(\mathrm{kN})-0,5 \mathrm{~Hz}$ & 56,79 & 58,34 & 50,86 & 49,68 & 44,98 \\
$F_{\min }(\mathrm{kN})-0,5 \mathrm{~Hz}$ & 1,77 & 1,70 & 1,70 & 4,41 & 1,80 \\
$F_{\max }(\mathrm{kN})-5 \mathrm{~Hz}$ & 55,14 & 55,08 & 50,85 & 49,69 & 43,80 \\
$F_{\min }(\mathrm{kN})-5 \mathrm{~Hz}$ & 2,70 & 1,72 & 1,72 & 4,44 & 3,70 \\
$F_{\max }-F_{\min }(\mathrm{kN})-5 \mathrm{~Hz}$ & 52,44 & 53,36 & 49,13 & 45,25 & 40,10 \\
$F_{\max }-F_{\min }(\%)-5 \mathrm{~Hz}$ & 84,25 & 85,73 & 78,94 & 72,70 & 64,43 \\
No ciclos 1a fissura & 1 & 1 & 3 & 1 & 1 \\
No ciclos na ruína & 4646 & 6867 & 7749 & 12984 & 60770 \\
\hline
\end{tabular}

\section{c. Séries Q196 e Q283}

Na figura 5.17 é apresentado o diagrama força aplicada - deformação média na armadura para os ensaios estáticos das duas séries.

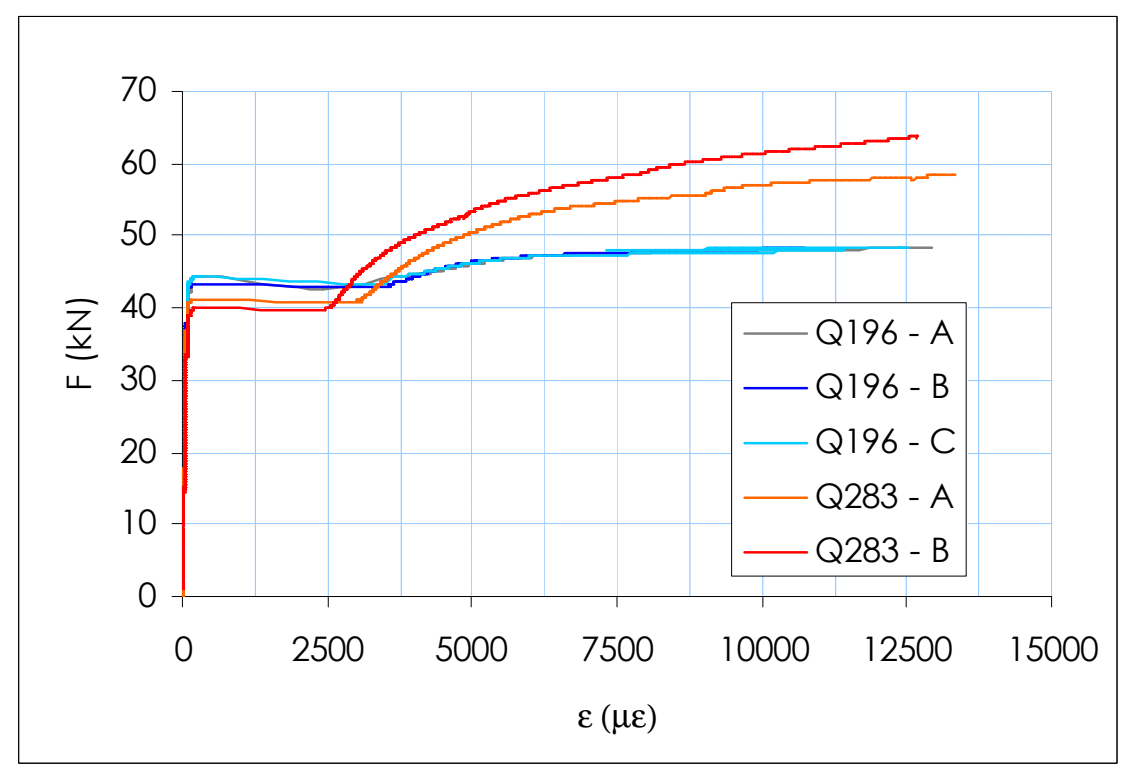

Figura 5.17 - Diagrama força aplicada - deformação na armadura, para os ensaios estáticos da primeira etapa 
Na figura 5.18 é apresentado o diagrama força aplicada - deformação média no concreto para os ensaios com tela Q196.

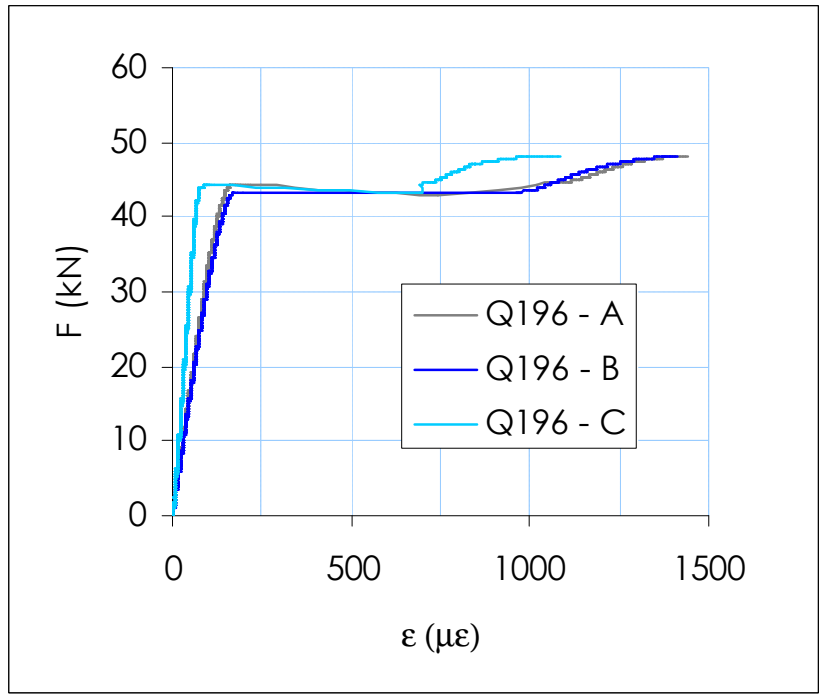

Figura 5.18 - Diagrama força aplicada - deformação no concreto, para os ensaios estáticos da primeira etapa

As deformações da armadura no decorrer do carregamento repetido estão apresentadas nas figuras 5.19 e 5.20 .

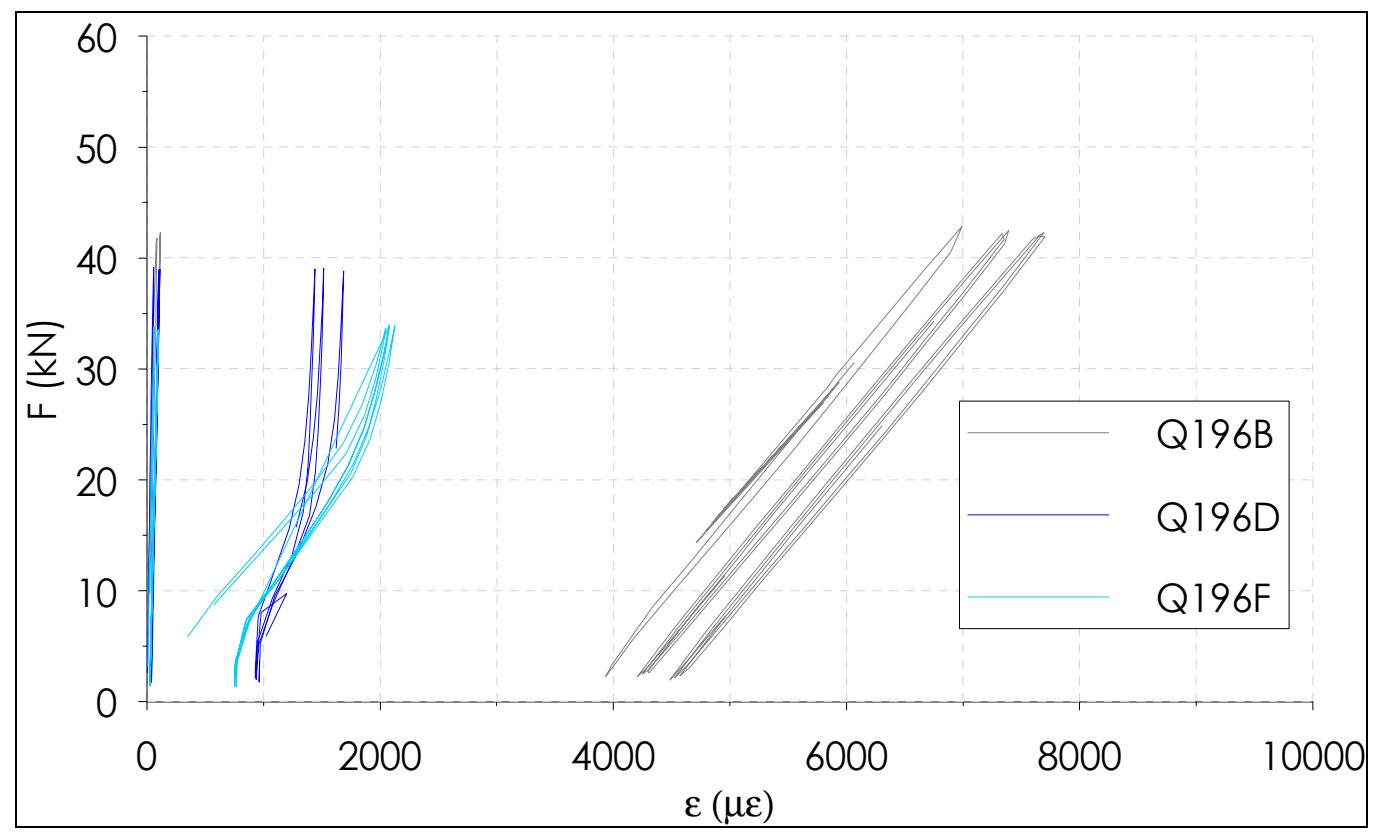

Figura 5.19 - Deformação da armadura das vigas da série Q196 da primeira etapa, no decorrer do carregamento repetido 


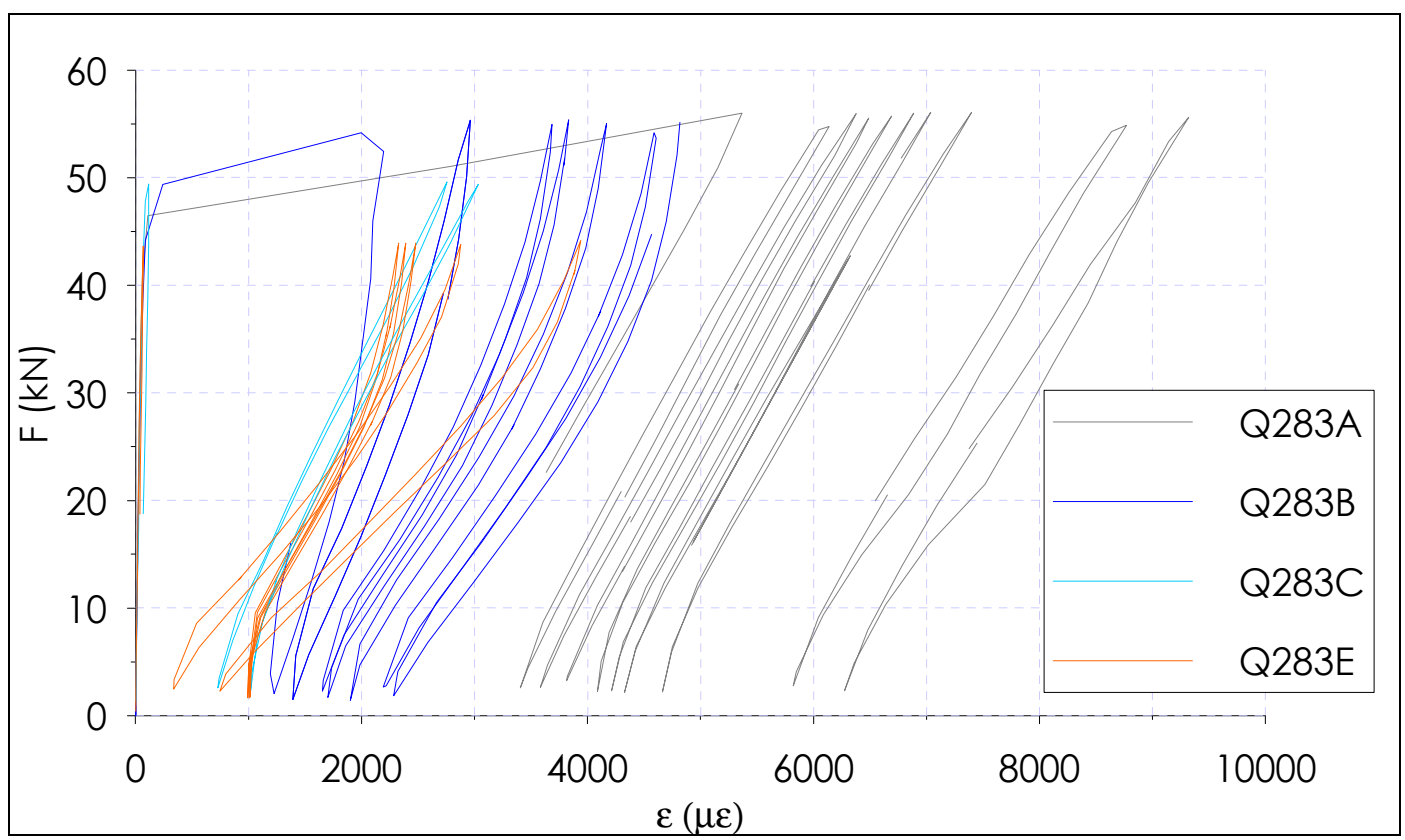

Figura 5.20 - Deformação da armadura das vigas da série Q283 da primeira etapa, no decorrer do carregamento repetido

Nas figura 5.19 e 5.20 percebe-se a diferença das deformações antes e depois da fissuração do concreto. A mudança de inclinação das curvas mostra a perda de rigidez do modelo com o decorrer do carregamento.

5.2 SEGUNDA ETAPA

Nesta etapa foram realizados ensaios de flexão com deslocamento controlado em vigas de concreto simples e concreto armado com três áreas de aço diferentes, a fim de determinar o comportamento pós-fissuração e os parâmetros necessários para a análise numérica. As vigas foram divididas em quatro séries:

- CS - vigas de concreto simples

- Série Q138 - vigas armadas com tela de $1,38 \mathrm{~cm}^{2} / \mathrm{m}$ e $\phi$ de $4,2 \mathrm{~mm}$

- Série Q196 - vigas armadas com tela de $1,96 \mathrm{~cm}^{2} / \mathrm{m}$ e $\phi$ de $5 \mathrm{~mm}$

- Série Q283 - vigas armadas com tela de $2,83 \mathrm{~cm}^{2} / \mathrm{m}$ e $\phi$ de $6 \mathrm{~mm}$

\subsubsection{GEOMETRIA}

Os principais parâmetros geométricos das vigas estão apresentados na tabela 5.7. 
Tabela 5.7 - Parâmetros geométricos das vigas da segunda etapa

\begin{tabular}{ccccc}
\hline Parâmetro & CS & Q138 & Q196 & Q283 \\
\hline Comprimento $(\mathrm{cm})$ & 50 & 50 & 50 & 50 \\
Vão $(\mathrm{cm})$ & 45 & 45 & 45 & 45 \\
Largura $(\mathrm{cm})$ & 15 & 15 & 15 & 15 \\
Altura $(\mathrm{cm})$ & 15 & 15 & 15 & 15 \\
Cobrimento $(\mathrm{cm})$ & - & 1,5 & 1,5 & 1,5 \\
Altura útil $(\mathrm{cm})$ & - & 12,79 & 12,75 & 12,7 \\
Área de aço $\left(\mathrm{cm}^{2}\right)$ & 0 & 0,2070 & 0,2940 & 0,4245 \\
$\phi(\mathrm{mm})$ & - & 4,2 & 5,0 & 6,0 \\
Taxa de armadura $(\%)$ & 0 & 0,09 & 0,13 & 0,19 \\
\hline
\end{tabular}

\subsubsection{PREPARAÇÃO DOS MODELOS}

Cada série possuía três modelos. Portanto foram construídas 12 vigas na segunda etapa da modelagem experimental.

Para moldagem dos modelos foram utilizadas formas metálicas, conforme mostrado na figura 5.21 .

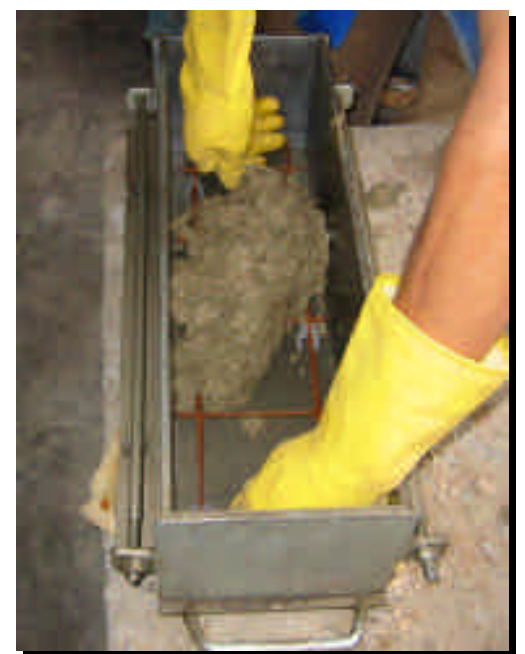

As armaduras foram posicionadas nas fôrmas com o auxílio de espaçadores de plástico. O modelo era concretado sobre uma mesa vibratória, tomando o cuidado de manter o posicionamento da armadura.

Figura 5.21 - Lançamento do concreto

\subsubsection{ESQUEMA GERAL DO ENSAIO E INSTRUMENTAÇÃO}

Os ensaios foram realizados no Laboratório de Estruturas do Departamento de Engenharia de Estruturas da EESC. Foi utilizada uma máquina de ensaio hidráulica servo-controlada, modelo 8506, marca Instron. O esquema de ensaio é o mesmo da figura 5.3.

A instrumentação dos ensaios de flexão das vigas está mostrada nas figuras 5.22 e 5.23 . 


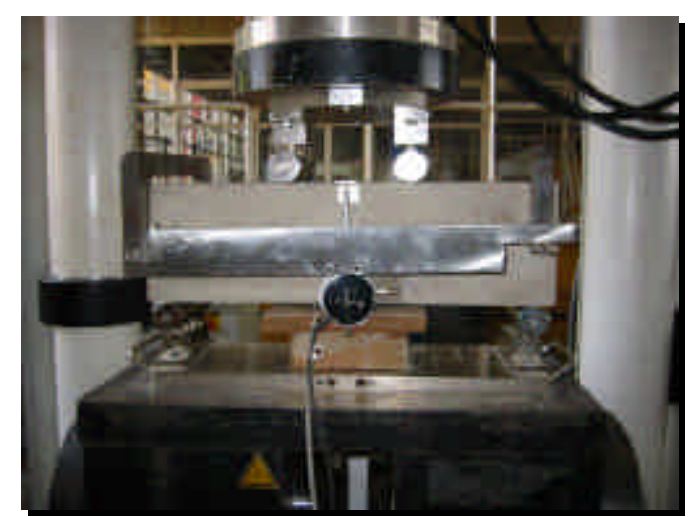

Figura 5.22 - Posicionamento do transdutor vertical

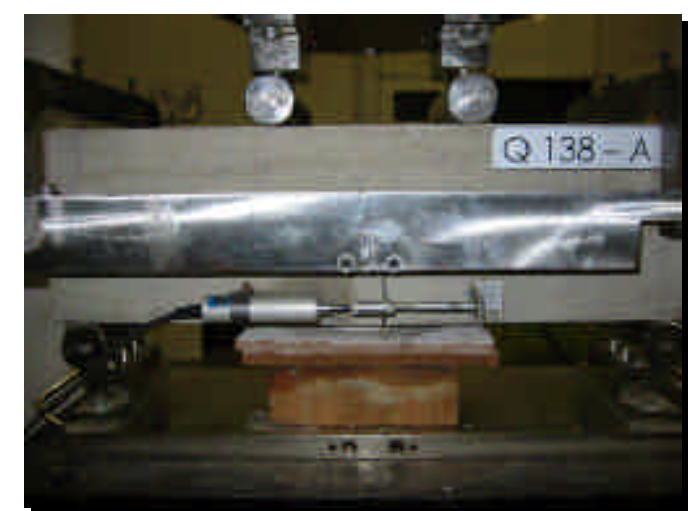

Figura 5.23 - Posicionamento do transdutor horizontal
Em cada viga foi posicionado um transdutor a fim de medir os deslocamentos, no meio do vão. Nas vigas sem tela foram posicionados extensômetros na parte inferior, no terço central.

Nas vigas com tela, além do transdutor para medir deslocamentos verticais, outro transdutor foi posicionado na direção horizontal, a fim de medir a deformação equivalente média. Os pontos fixos têm distância de $17,75 \mathrm{~cm}$.

\subsubsection{RESULTADOS}

Os resultados dos ensaios de caracterização estão apresentados na tabela 5.8.

Tabela 5.8 - Resultados dos ensaios de caracterização da segunda etapa

\begin{tabular}{cccc}
\hline $\mathrm{CP}$ & Idade do CP (dias) & $\mathrm{f}_{\mathrm{c}}\left(\mathrm{kN} / \mathrm{cm}^{2}\right)$ & $\mathrm{f}_{\mathrm{c}}(\mathrm{MPa})$ \\
\hline 1 & 19 & 5,57 & 55,73 \\
2 & 19 & 5,23 & 52,26 \\
3 & 19 & 5,20 & 52,00 \\
Média & 19 & 5,33 & 53,30 \\
\hline 4 & 27 & 6,07 & 60,65 \\
5 & 27 & 6,69 & 66,90 \\
6 & 27 & 6,23 & 62,25 \\
Média & 27 & 6,33 & 63,27 \\
\hline CP & Idade do CP (dias) & $\mathrm{f}_{\mathrm{ct}}(\mathrm{kN} / \mathrm{cm} 2)$ & $\mathrm{f}_{\mathrm{ct}}(\mathrm{MPa})$ \\
\hline 1 & 27 & 0,36 & 3,55 \\
2 & 27 & 0,48 & 4,77 \\
3 & 27 & 0,39 & 3,92 \\
Média & 27 & 0,41 & 4,08 \\
\hline CP & Idade do CP (dias) & $\mathrm{f}_{\mathrm{ct}}-\mathrm{flexão}(\mathrm{kN} / \mathrm{cm} 2)$ & $\mathrm{f}_{\mathrm{ct}}-\mathrm{flexão}(\mathrm{MPa})$ \\
\hline 1 & 27 & 0,41 & 4,07 \\
2 & 27 & 0,35 & 3,51 \\
3 & 27 & 0,45 & 4,53 \\
Média & 27 & 0,40 & 4,04 \\
\hline
\end{tabular}


Foram realizados ensaios para determinação do módulo de elasticidade do concreto, aos 27 dias. Cada corpo-de-prova possuía dois extensômetros removíveis, designados pelos números 1 e 2 no gráfico da figura 5.24. O módulo de elasticidade médio é igual a $36158 \mathrm{MPa}$.

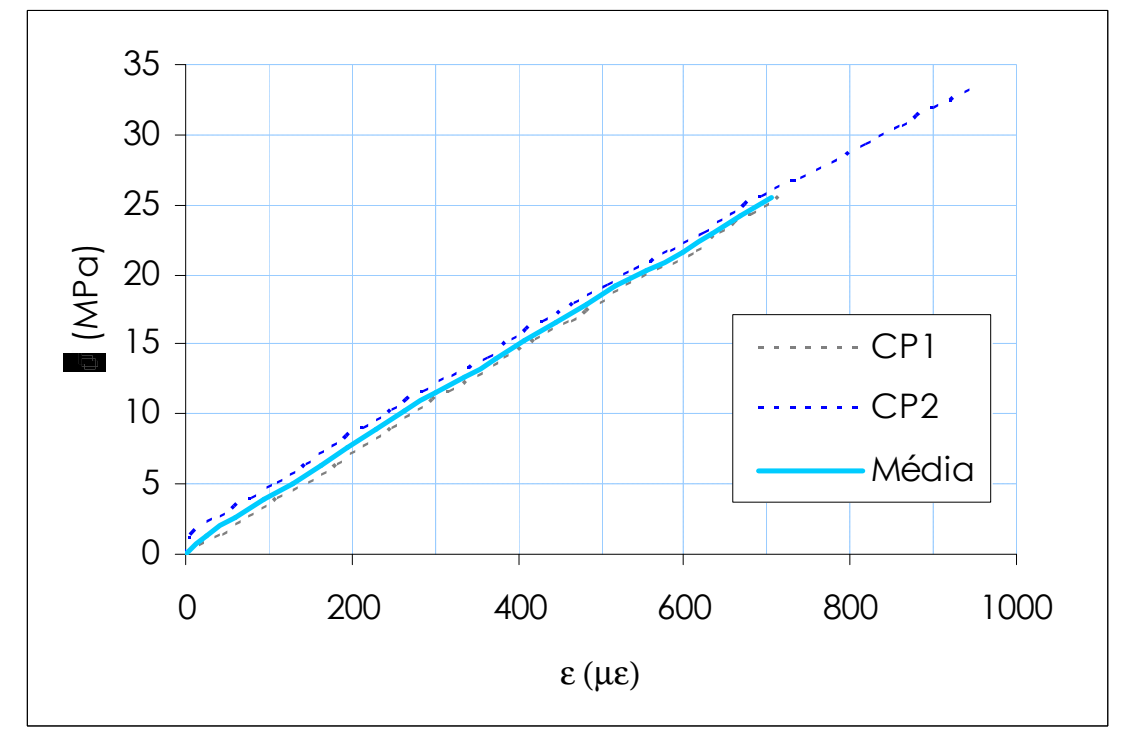

Figura 5.24 - Módulo de elasticidade do concreto, segunda etapa

O diagrama força-deslocamento vertical máximo para as vigas ensaiadas está apresentado na figura 5.25 .

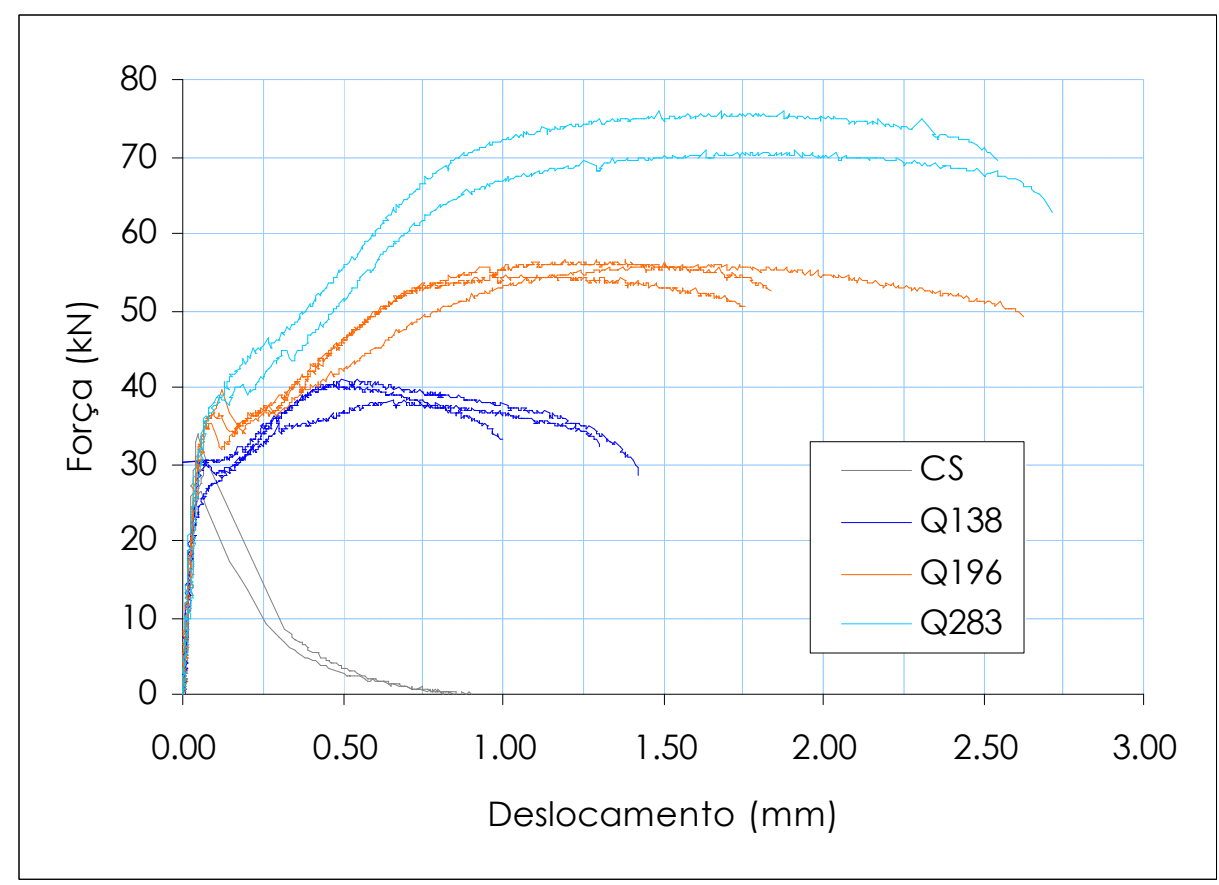

Figura 5.25 - Diagrama força-deslocamento vertical das vigas da segunda etapa 
Na figura 5.25 pode-se notar que, nas vigas sem armadura, logo após a fissuração do concreto a força cai bruscamente até zero. Nas vigas com armadura percebese um pequeno patamar que acusa a presença da primeira fissura. Após esse patamar a força de tração passa a ser transferida para o aço e há um aumento da força, proporcional à taxa de armadura. Depois de atingida a força máxima, ocorre uma leve queda da força e um grande aumento de deformação, até que a viga chega à ruína por deformação excessiva da armadura, dividindo-se em duas partes. As forças de fissuração e força máxima obtidas para cada modelo estão apresentadas na tabela 5.9.

Tabela 5.9 - Forças de fissuração e máximas nas vigas da segunda etapa

\begin{tabular}{cccc}
\hline Modelo & $\begin{array}{c}\text { Força de fissuração, } \\
\text { aproximada (kN) }\end{array}$ & Força máxima $(\mathrm{kN})$ & Diferença (kN) \\
\hline CS-A & 30,52 & 30,52 & - \\
CS - B & 26,32 & 26,32 & - \\
CS-C & 33,95 & 33,95 & - \\
Q138-A & 25,50 & 40,44 & 14,94 \\
Q138-B & 30,00 & 38,46 & 8,46 \\
Q138-C & 30,00 & 41,13 & 11,13 \\
Q196-A & 35,20 & 56,16 & 20,96 \\
Q196-B & 35,00 & 54,56 & 19,56 \\
Q196-C & 35,20 & 56,69 & 21,49 \\
Q283-B & 35,30 & 76,00 & 40,70 \\
Q283-C & 35,30 & 70,81 & 35,51 \\
\hline
\end{tabular}

Na figura 5.26 são apresentados os diagramas força-deformação equivalente, traçados para as vigas com telas soldadas. A deformação média equivalente é dada pela leitura do transdutor horizontal dividida pela distância entre os pontos fixos $(177,5 \mathrm{~mm})$.

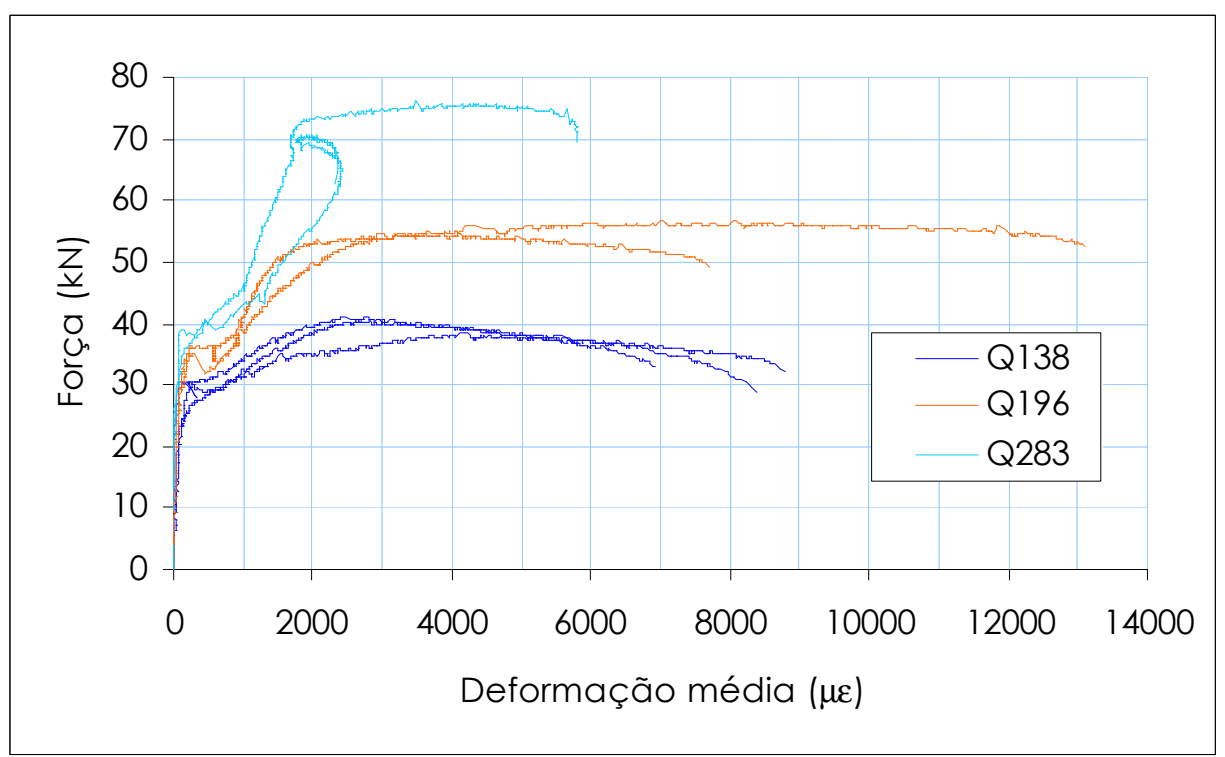

Figura 5.26 - Diagrama força aplicada - deformação média equivalente para as vigas armadas da segunda etapa 
As deformações medidas pelos extensômetros colados nas vigas sem tela estão apresentadas na figura 5.27.

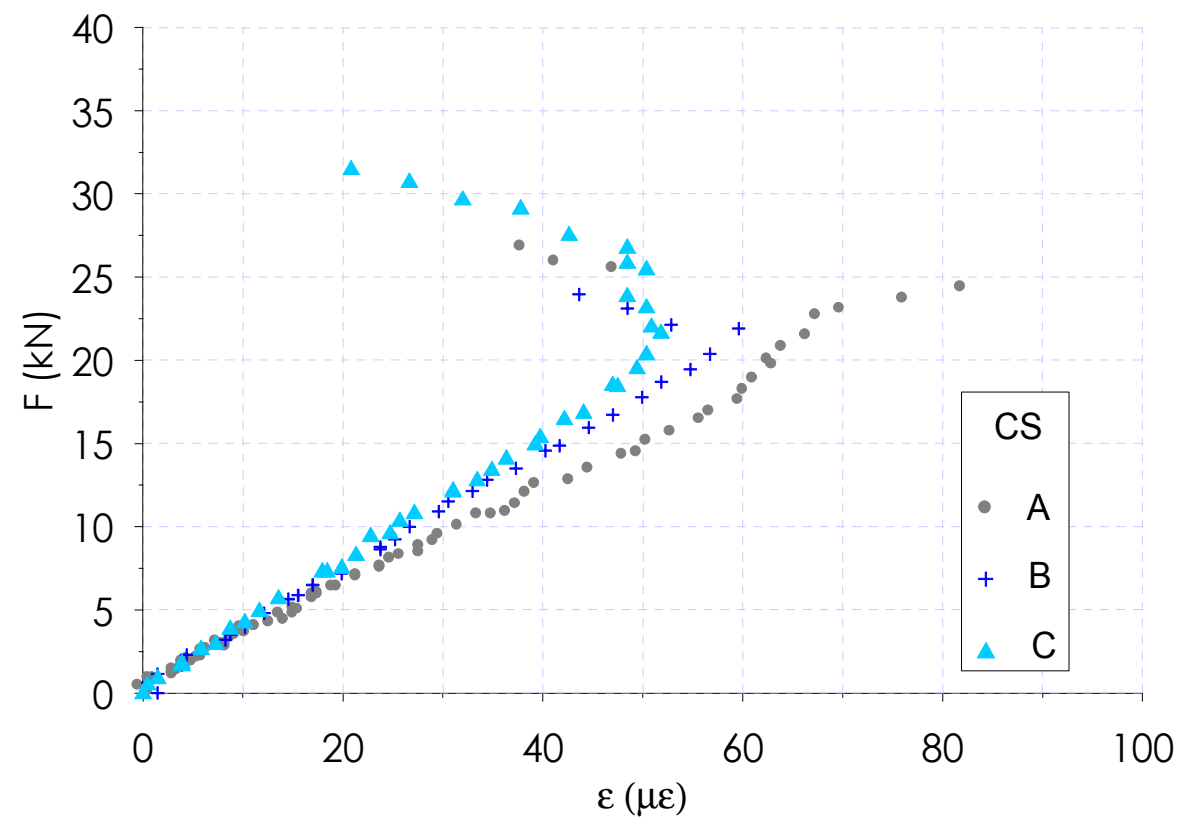

Figura 5.27 - Diagrama força-deformação das vigas de concreto simples

Na figura 5.28, é possível comparar as deformações calculadas para as vigas de concreto armado e as deformações medidas pelos extensômetros nas vigas de concreto simples. Percebe-se que os trechos iniciais têm inclinações semelhantes, sendo que após a fissuração os extensômetros apresentam queda na leitura enquanto os transdutores medem a abertura das fissuras.

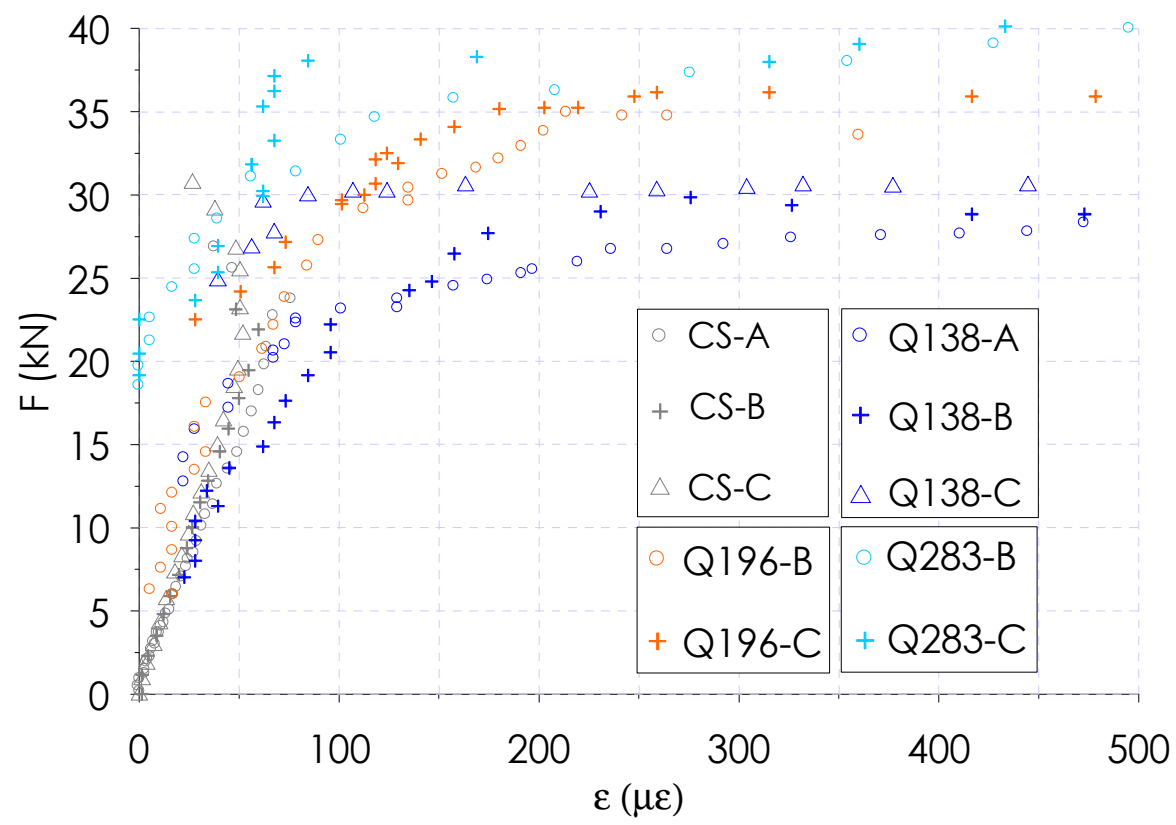

Figura 5.28 - Diagrama força-deformação das vigas de concreto simples e de concreto armado 
A configuração das fissuras e a ruína dos modelos estão mostradas nas figuras 5.29 a 5.32 .

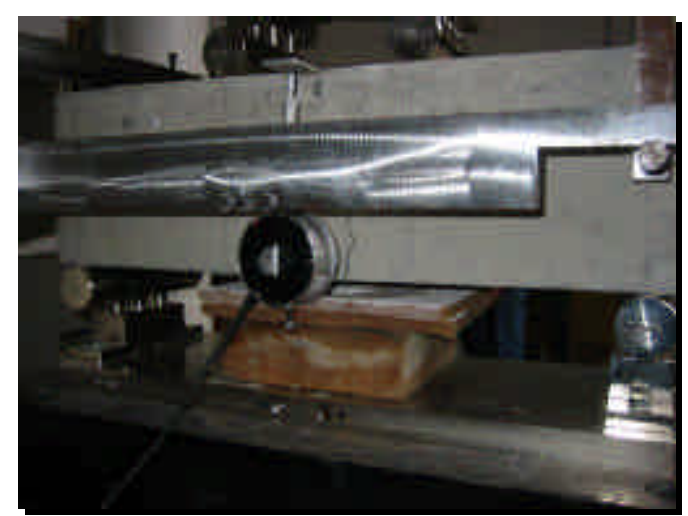

Figura 5.29 - Fissuração de viga sem armadura

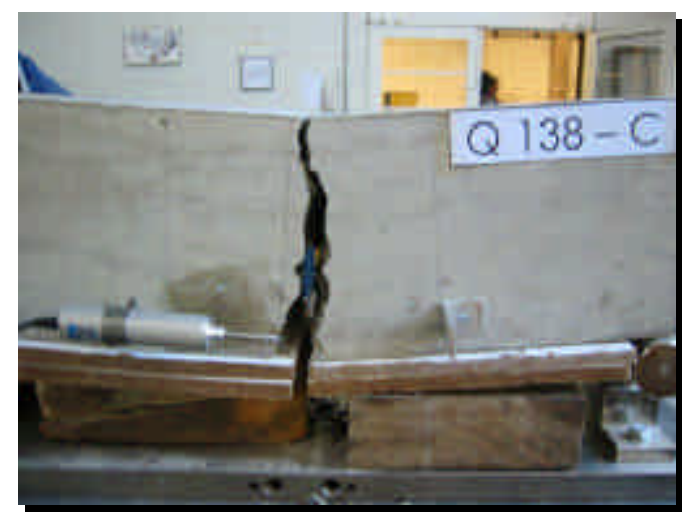

Figura 5.30 - Ruína de viga com tela Q138

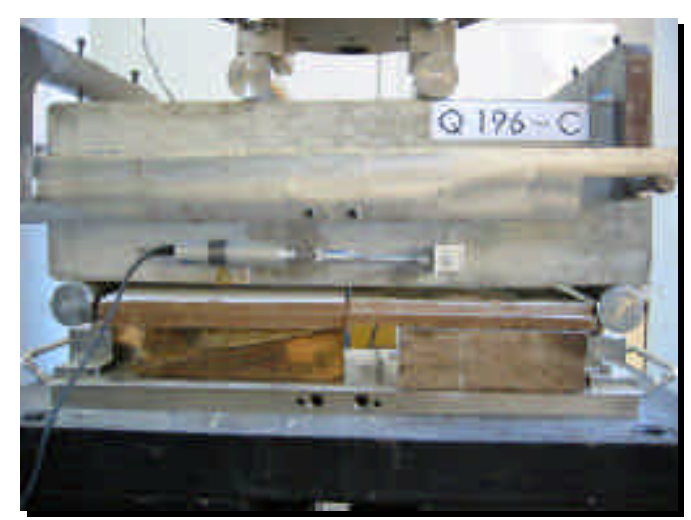

Figura 5.31 - Fissuração de viga com tela Q196
Nas vigas sem armadura ocorreu a

formação de apenas uma fissura, dentro do terço central. Essa fissura se abre até a separação do modelo em duas partes.

Nas vigas da série Q138 também houve a formação de uma única fissura, que ao aumentar provocava a ruína da peça, separando-a em duas partes.

Nas vigas da série Q196 eram formadas duas fissuras. Uma delas, ao aumentar de espessura, provocava a ruína do modelo, separando-o em duas partes. 


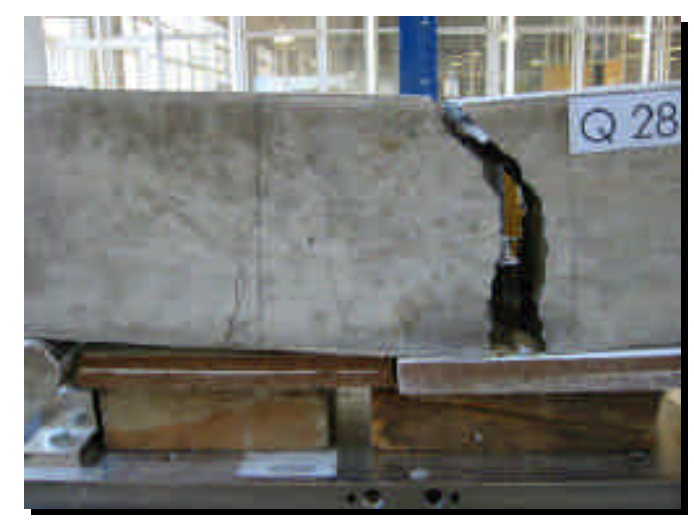

Figura 5.32 - Ruína de viga com tela Q283
Na série Q283 eram formadas três fissuras, sendo que uma delas chegava a dividir o modelo em duas partes.

\subsection{TERCEIRA ETAPA}

A terceira etapa tem como objetivo o estudo do comportamento de placas de concreto estruturalmente armadas sob carregamento monotônico e carregamento repetido.

\subsubsection{GEOMETRIA}

Para o estudo foram analisados modelos de placas e faixas de concreto simples e de concreto armado. As faixas são vigas com altura e armadura semelhantes às das placas. A geometria dos modelos utilizados na terceira etapa está resumida na tabela 5.10.

Tabela 5.10 - Geometria dos modelos da terceira etapa

\begin{tabular}{ccccc}
\hline Parâmetro & Placa CS & Placa Q138 & Faixa CS & Faixa Q138 \\
\hline Comprimento $(\mathrm{cm})$ & 200 & 200 & 70 & 70 \\
Vão $(\mathrm{cm})$ & U.a. $^{*}$ & U.a.* & 60 & 60 \\
Largura $(\mathrm{cm})$ & 200 & 200 & 30 & 30 \\
Altura $(\mathrm{cm})$ & 8 & 8 & 8 & 8 \\
Cobrimento $(\mathrm{cm})$ & - & 1,5 & - & 1,5 \\
Altura útil $(\mathrm{cm})$ & - & 6,29 & - & 6,29 \\
$\phi(\mathrm{mm})$ & - & 4,2 & - & 4,2 \\
Taxa de armadura $(\%)$ & - & 0,17 & - & 0,17 \\
\hline
\end{tabular}

*uniformemente apoiada

As dimensões das placas foram escolhidas de acordo com o vão permitido pelo pórtico de atuação de força do laboratório. Em função da largura da placa, foi adotada uma altura reduzida a fim de diminuir a rigidez relativa. 


\subsubsection{PREPARAÇÃO DOS MODELOS}

Foram construídas oito placas e oito faixas, sendo seis de concreto armado e duas de concreto simples.

Os modelos foram concretados em duas etapas, com concreto usinado. Em cada etapa foram moldadas quatro placas e quatro faixas. Depois de dez dias da primeira concretagem, os modelos foram desformados, a fim de preparar as fôrmas para a segunda. A seqüência de concretagem e desforma dos modelos está apresentada nas figuras 5.33 a 5.38 .

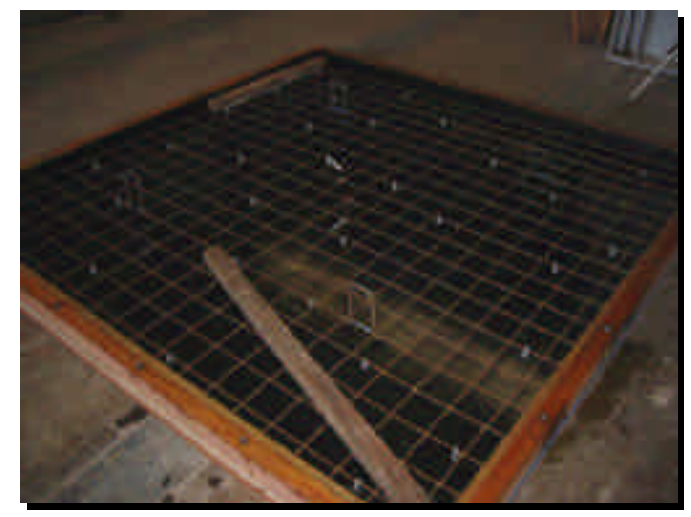

Figura 5.33 - Fôrma para placa de $2 \mathrm{~m} \times 2 \mathrm{~m}$

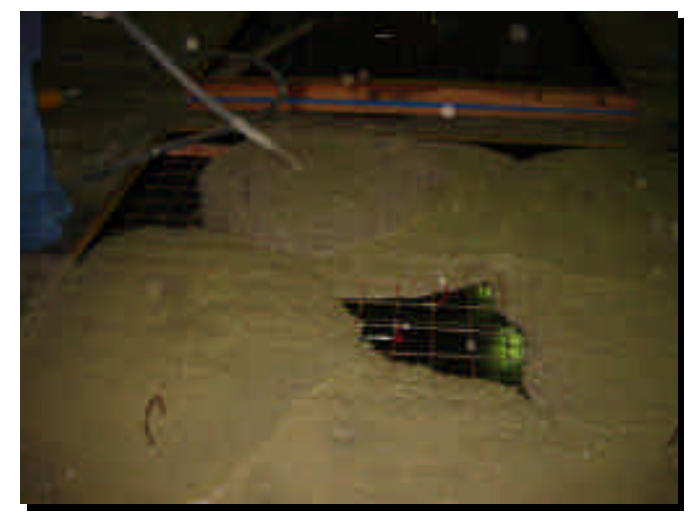

Figura 5.34 - Início da concretagem das placas
As telas foram posicionadas com espaçadores plásticos, que garantem o cobrimento de $1,5 \mathrm{~cm}$. Foram posicionados quatro ganchos amarrados à tela nos quartos dos vãos, a fim de facilitar o içamento da peça no instante de desforma.

Conforme o concreto era despejado nas fôrmas, o adensamento era feito com um vibrador de agulha. 


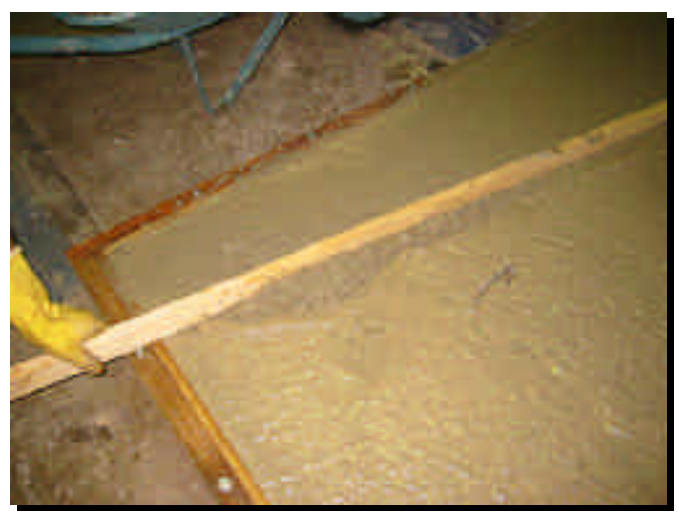

Figura 5.35 - Acabamento com régua

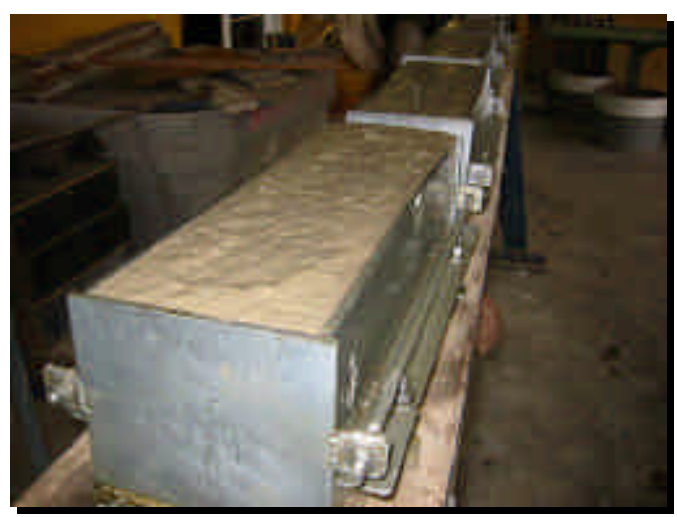

Figura 5.36-Concretagem dos CP's para tração

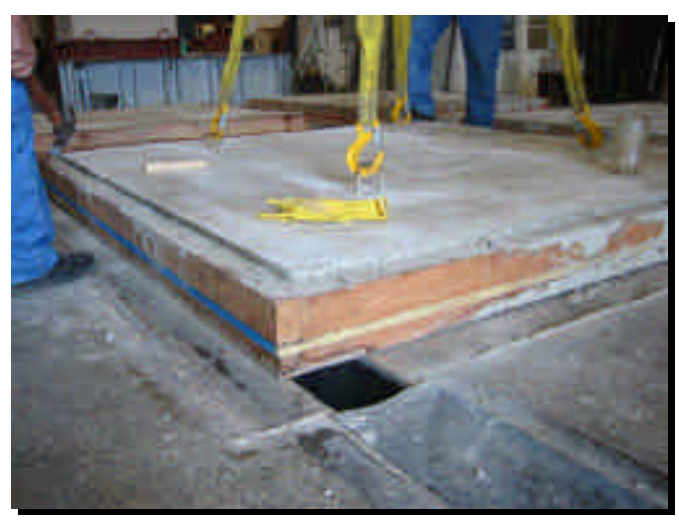

Figura 5.37 - Retirada das placas das fôrmas
Depois de preenchida toda a fôrma, fezse um acabamento superficial com régua de madeira e em seguida com a desempenadeira.

Em cada dia de concretagem foram moldados também quatro vigas de $15 x$ $15 \times 50 \mathrm{~cm}$, para ensaio de tração na flexão, e 10 CP's cilíndricos de $10 \mathrm{~cm} \times 20$ $\mathrm{cm}$, para ensaio de compressão e módulo de elasticidade.

Com auxílio da ponte rolante, as placas foram içadas e retiradas das fôrmas. 


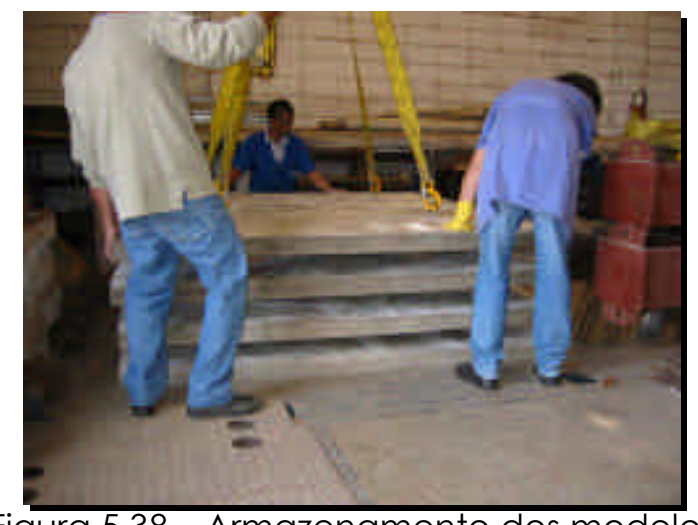

Até os dias de ensaio as placas foram empilhadas, colocando-se apoios lineares (caibros) próximos aos quartos do vão.

Figura 5.38 - Armazenamento dos modelos

Na tabela 5.11 são listados os modelos e a ordem em que foram concretados.

Tabela 5.11 - Modelos da terceira etapa

\begin{tabular}{ccc}
\hline Modelo & Descrição & Concretagem \\
\hline PCS1 & Placa de concreto simples & Segunda \\
PCS2 & Placa de concreto simples & Segunda \\
PCA1 & Placa de concreto armado & Segunda \\
PCA2 & Placa de concreto armado & Segunda \\
VCS1 & Viga de concreto simples & Segunda \\
VCA1 & Viga de concreto armado & Segunda \\
VCA2 & Viga de concreto armado & Primeira \\
PCA3 & Placa de concreto armado & Primeira \\
PCA4 & Placa de concreto armado & Primeira \\
PCA5 & Placa de concreto armado & Primeira \\
PCA6 & Placa de concreto armado & Primeira \\
\hline
\end{tabular}

\subsubsection{ESQUEMA GERAL DO ENSAIO}

Os ensaios das faixas seguiram o mesmo esquema da figura 5.3. As placas foram apoiadas sobre blocos de isopor, posicionados sob o pórtico de reação conforme indicado na figura 5.39. Foi utilizado atuador servo-controlado, que possibilita o ensaio com controle de deslocamento. Entre os blocos da base e as placas de concreto era espalhada uma camada fina de areia para garantir o apoio uniforme da placa. 


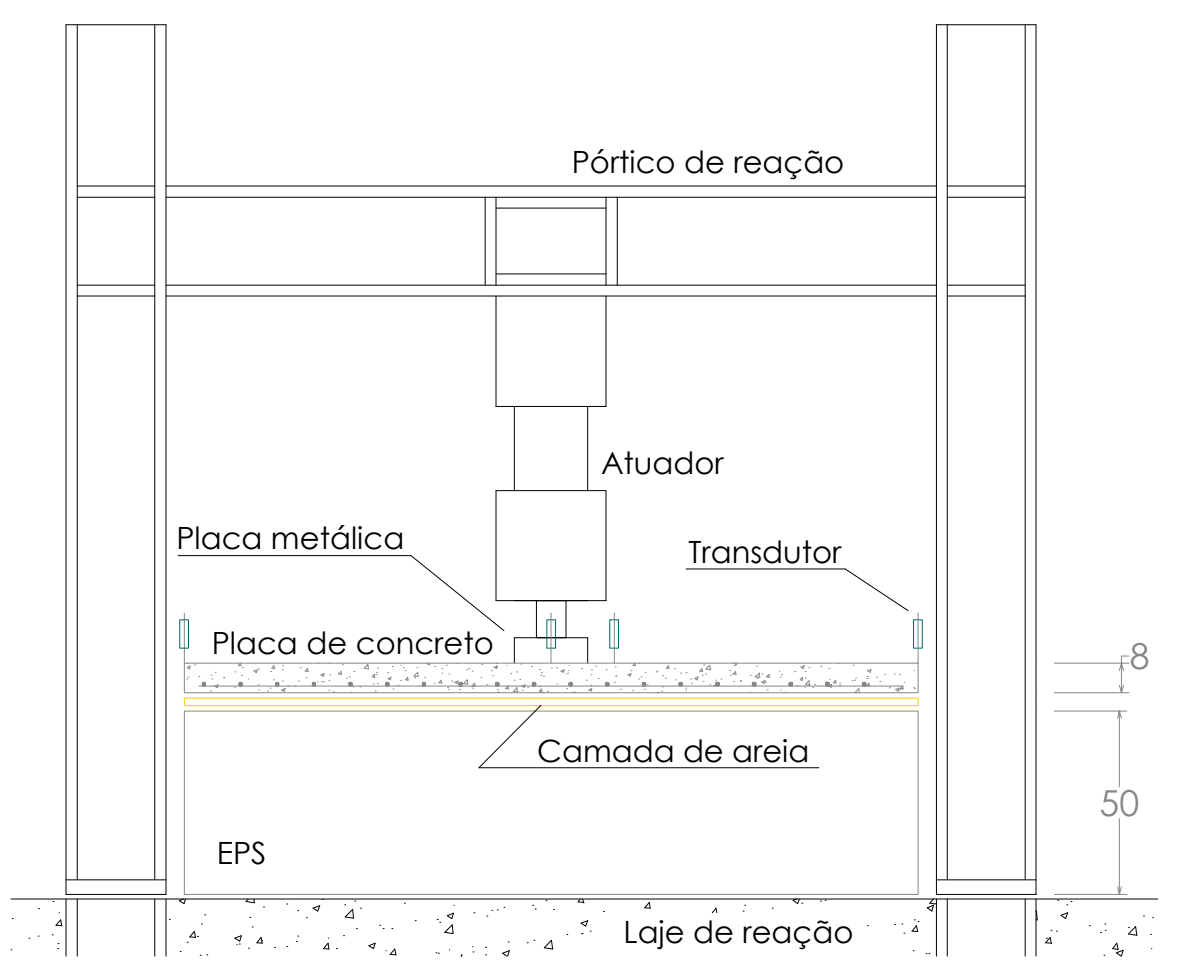

Figura 5.39 - Vista frontal do esquema geral do ensaio de placas; unidade: $\mathrm{cm}$

Os blocos de isopor tinham dois formatos diferentes. O primeiro com comprimento de $150 \mathrm{~cm}$, largura e altura de $50 \mathrm{~cm}$, o segundo com comprimento e largura de $100 \mathrm{~cm}$ e altura de $50 \mathrm{~cm}$. Esses blocos eram posicionados sob a placa de concreto, conforme mostrado na figura 5.40 .

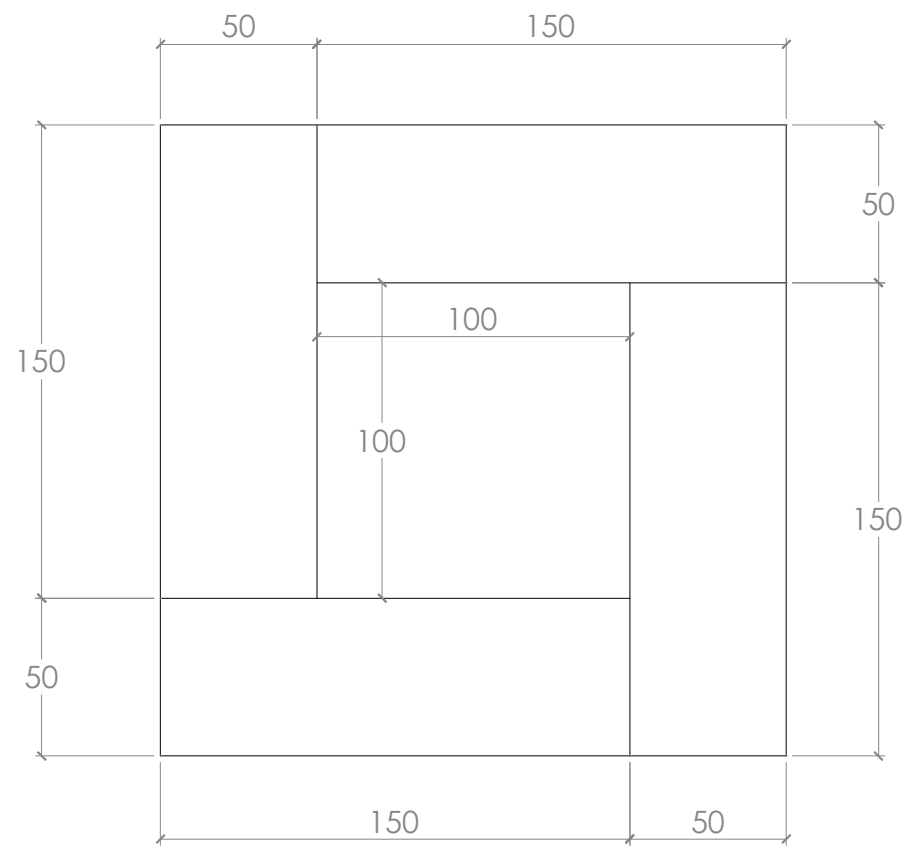

Figura 5.40 - Disposição dos blocos de isopor (EPS) sob a placa de concreto; unidade: $\mathrm{cm}$ 
Na região central da armadura foram colados quatro extensômetros elétricos, conforme mostrado na figura 5.41 .

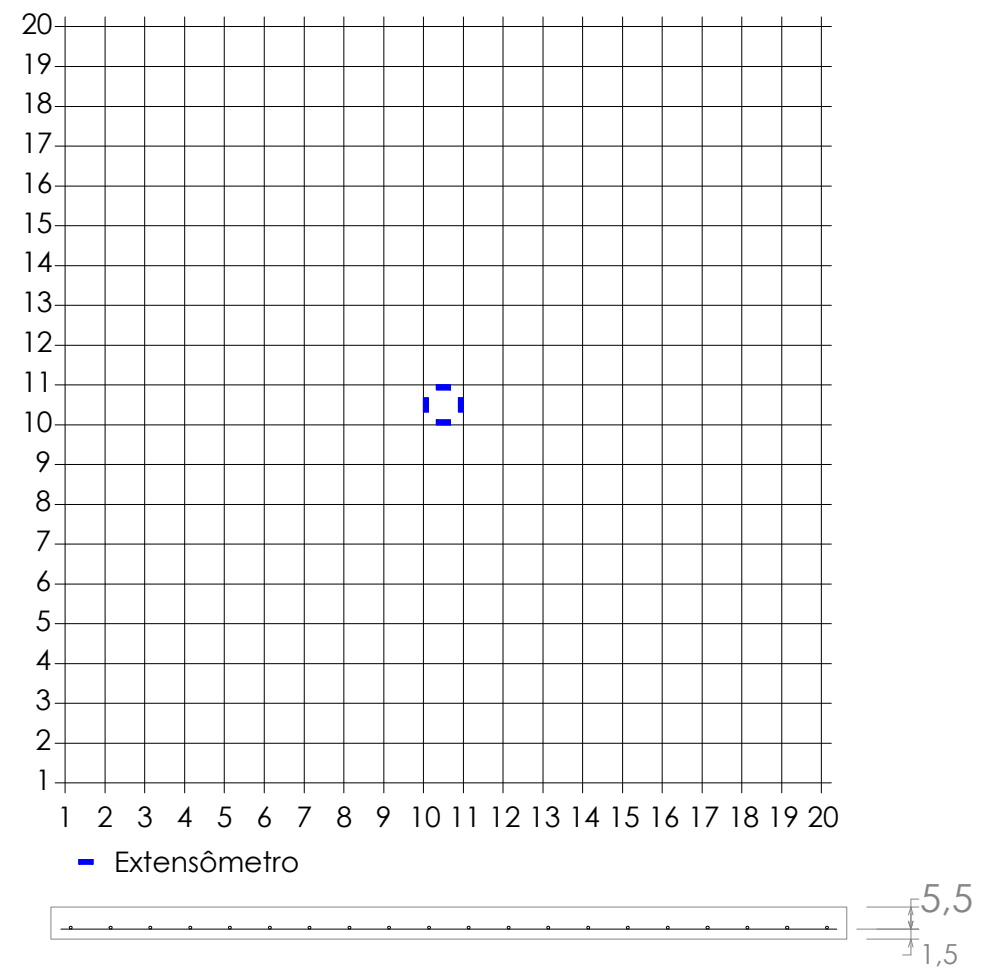

Figura 5.41 - Instrumentação da tela soldada para ensaio de placas; unidade: $\mathrm{cm}$

Foram posicionados seis transdutores de deslocamento na placa, conforme a figura 5.42. A área de aplicação da força é quadrada com $20 \mathrm{~cm}$ de lado.

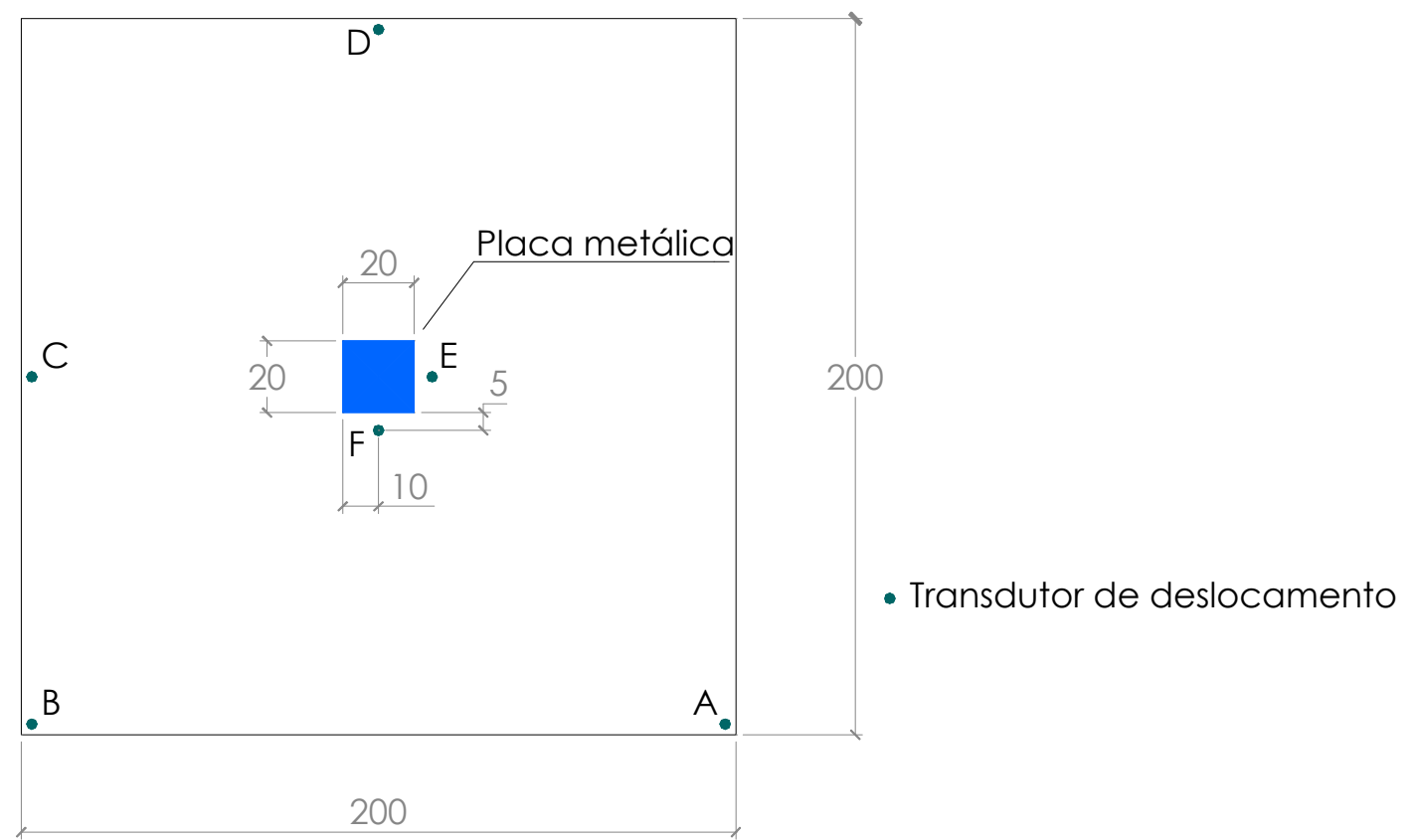

Figura 5.42 - Posicionamento dos extensômetros nos ensaios de placas da terceira etapa; unidade: $\mathrm{cm}$ 


\subsubsection{RESULTADOS}

Os corpos-de-prova da primeira e da segunda concretagem foram ensaiados aos 87 e 73 dias respectivamente. Os resultados dos ensaios de resistência à compressão e à tração na flexão estão apresentados na tabela 5.12.

Tabela 5.12 - Resultados dos ensaios de caracterização da terceira etapa

\begin{tabular}{cccc}
\hline Concretagem / CP & ldade do CP (dias) & $\mathrm{f}_{\mathrm{c}}\left(\mathrm{kN} / \mathrm{cm}^{2}\right)$ & $\mathrm{f}_{\mathrm{c}}(\mathrm{MPa})$ \\
\hline $1 / 1$ & 87 & 4,10 & 40,96 \\
$1 / 2$ & 87 & 3,82 & 38,17 \\
$1 / 3$ & 87 & 3,95 & 39,45 \\
$1 / 4$ & 87 & 3,68 & 36,79 \\
$1 / 5$ & 87 & 3,80 & 38,01 \\
Média & & 3,87 & 38,68 \\
\hline 2 / & 73 & 3,08 & 30,84 \\
2 / 2 & 73 & 3,00 & 30,04 \\
2 / 3 & 73 & 2,86 & 28,60 \\
$2 / 4$ & 73 & 3,32 & 33,16 \\
2 / 5 & 73 & 3,28 & 32,81 \\
Média & & 3,11 & 31,09 \\
\hline CP & ldade do CP (dias) & $\mathrm{fct}_{\mathrm{ct}}\left(\mathrm{kN} / \mathrm{cm}^{2}\right)$ & $\mathrm{f}_{\mathrm{ct}}(\mathrm{MPa})$ \\
$1 / 1$ & 87 & 0,40 & 4,01 \\
$1 / 2$ & 87 & 0,36 & 3,57 \\
$1 / 3$ & 87 & 0,33 & 3,33 \\
$1 / 4$ & 87 & 0,39 & 3,95 \\
Média & 87 & 0,37 & 3,71 \\
\hline $2 / 1$ & 73 & 0,30 & 3,01 \\
2 / 2 & 73 & 0,31 & 3,12 \\
2 / 3 & 73 & 0,32 & 3,23 \\
2 / 4 & 73 & 0,27 & 2,69 \\
Média & & 0,30 & 3,06 \\
\hline
\end{tabular}

Os ensaios de módulo de elasticidade resultaram nos gráficos das figuras 5.43 e 5.44, para a primeira e a segunda concretagem, respectivamente.

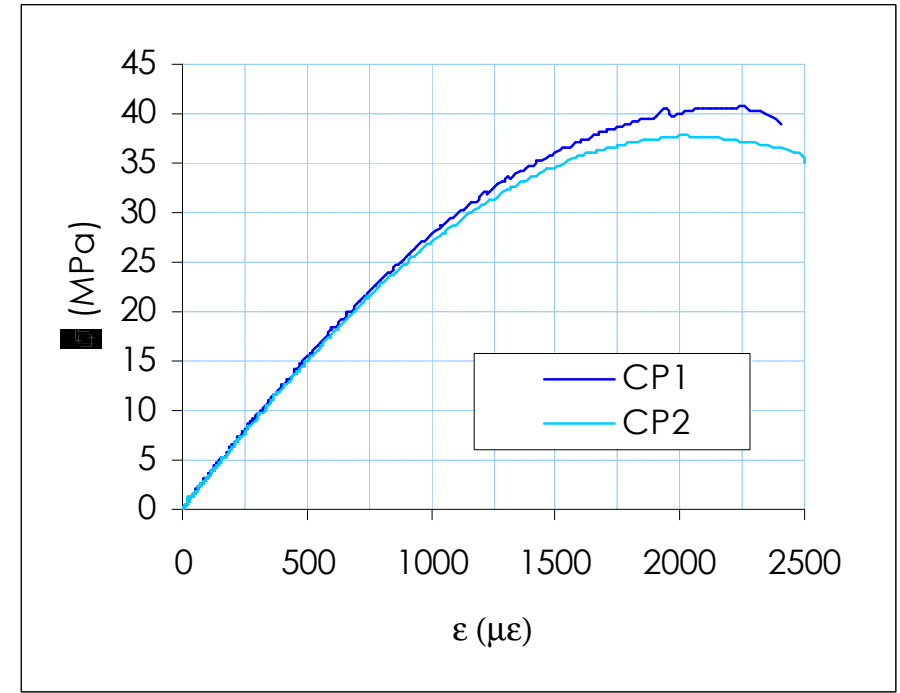

Figura 5.43 - Ensaio de módulo de elasticidade da primeira concretagem da terceira etapa 


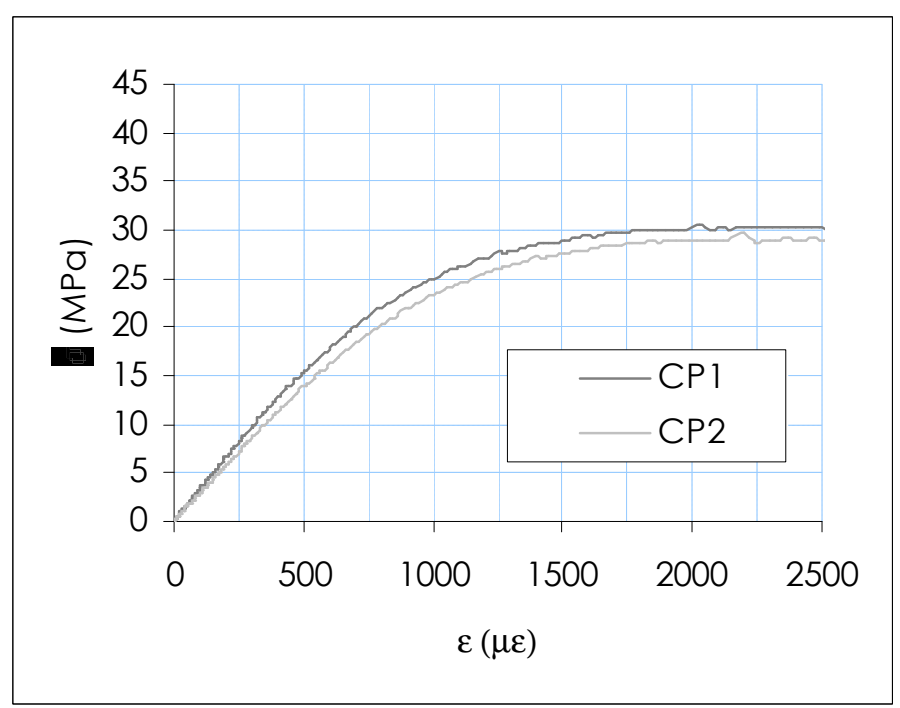

Figura 5.44 - Ensaio de módulo de elasticidade da segunda concretagem da terceira etapa

Pode-se determinar que para o concreto da primeira concretagem, o módulo de elasticidade tangente é de $27387 \mathrm{MPa}$. Para o concreto da segunda concretagem, o módulo é de $29121 \mathrm{MPa}$.

Para caracterização do isopor foram ensaiados à compressão cinco blocos de base quadrada de $30 \mathrm{~cm}$ de lado e altura de $50 \mathrm{~cm}$. Na figura 5.45 é mostrado o diagrama força - deslocamento obtido a partir desse ensaio.

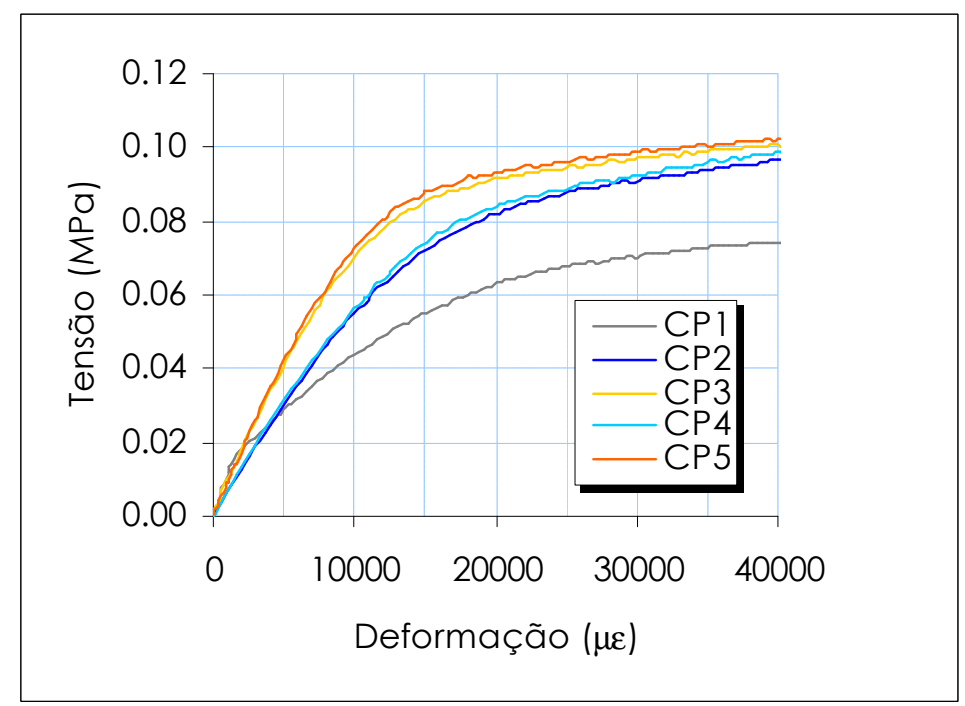

Figura 5.45 - Ensaio de caracterização do isopor

O isopor não apresenta comportamento linear. Um modelo possível para aproximar o seu módulo de elasticidade é uma reta secante à curva, unindo o ponto inicial ao final de ensaio, dessa forma o módulo de elasticidade é de 
2,5 MPa. Dividindo esse valor pela altura do corpo-de-prova, obtém-se um módulo de reação de $5 \mathrm{MPa} / \mathrm{m}$.

\section{a. Ensaios estáticos em faixas}

Três vigas foram submetidas e ensaios estáticos. PCS1, PCA1 e PCA2. O diagrama força - deformação na armadura está apresentado na figura 5.46.

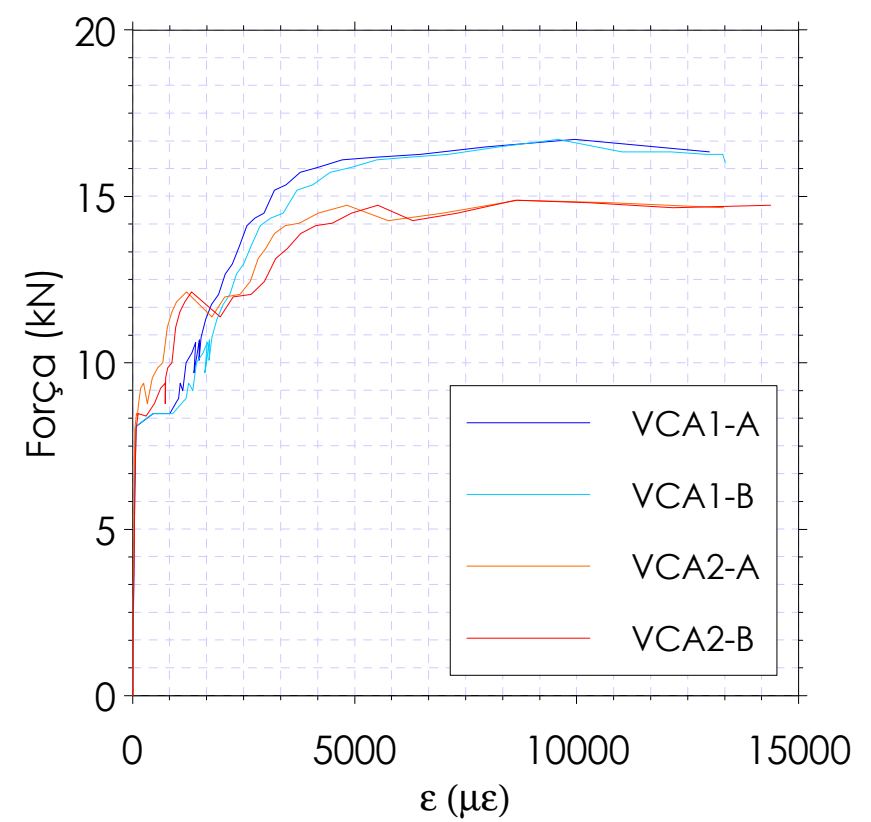

Figura 5.46 - Força - deformação na armadura nas faixas de concreto armado ensaio estático com deformação controlada

A faixa de concreto simples atingiu uma força máxima de 10,76 kN. A armadura proporciona um ganho na força máxima de 6 kN, $56 \%$.

b. Ensaios estáticos com deslocamento controlado - placas

Quatro placas foram submetidas a ensaio com carregamento monotônico: PCA 1, PCA2, PCA3 e PCS1. Por causa de problemas na montagem do ensaio o modelo PCAl não ficou uniformemente apoiado sobre a base, portanto seus resultados foram descartados. Nos gráficos das figuras 5.47, 5.48 e 5.49 são apresentados os deslocamentos nas demais placas ensaiadas com carregamento monotônico. 


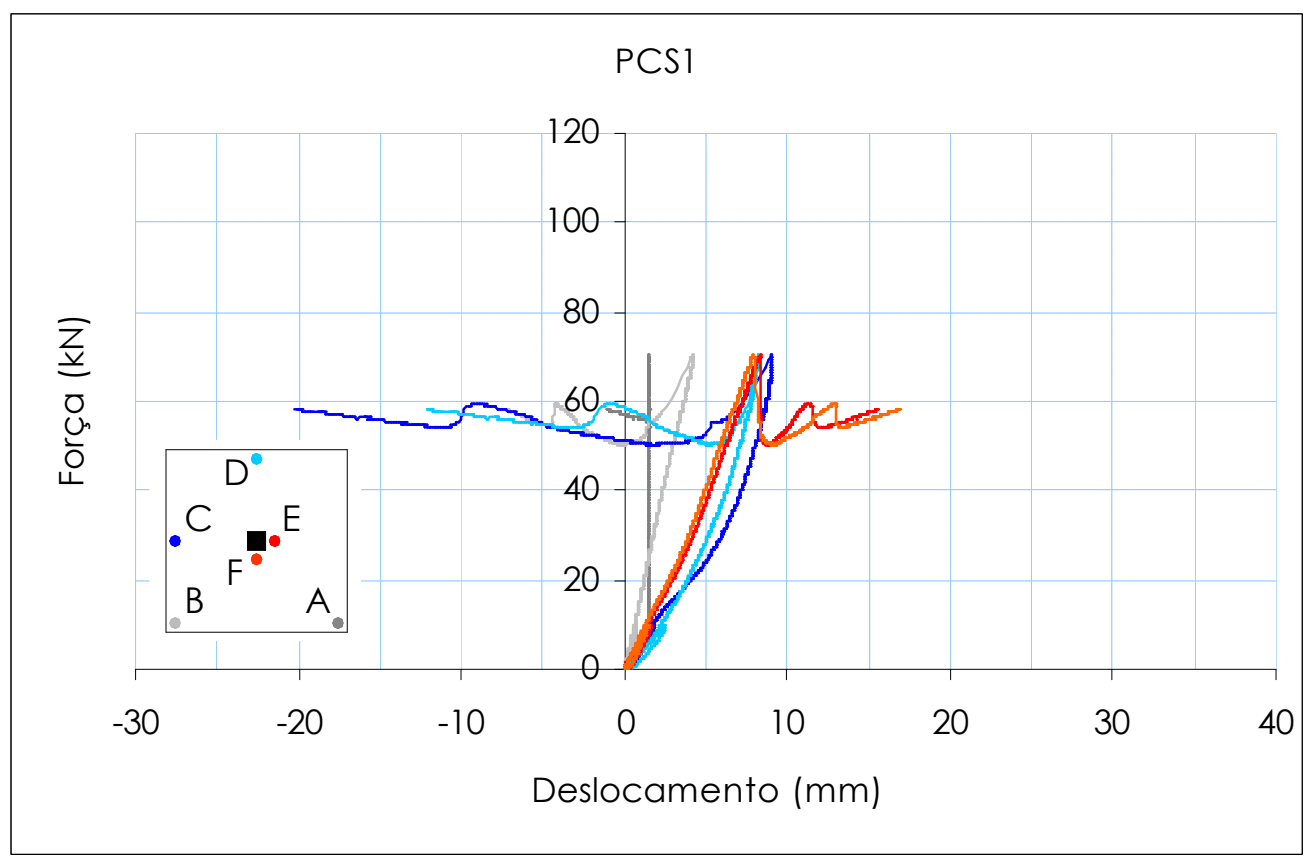

Figura 5.47 - Força - deslocamento na placa de concreto simples - ensaio estático com deformação controlada

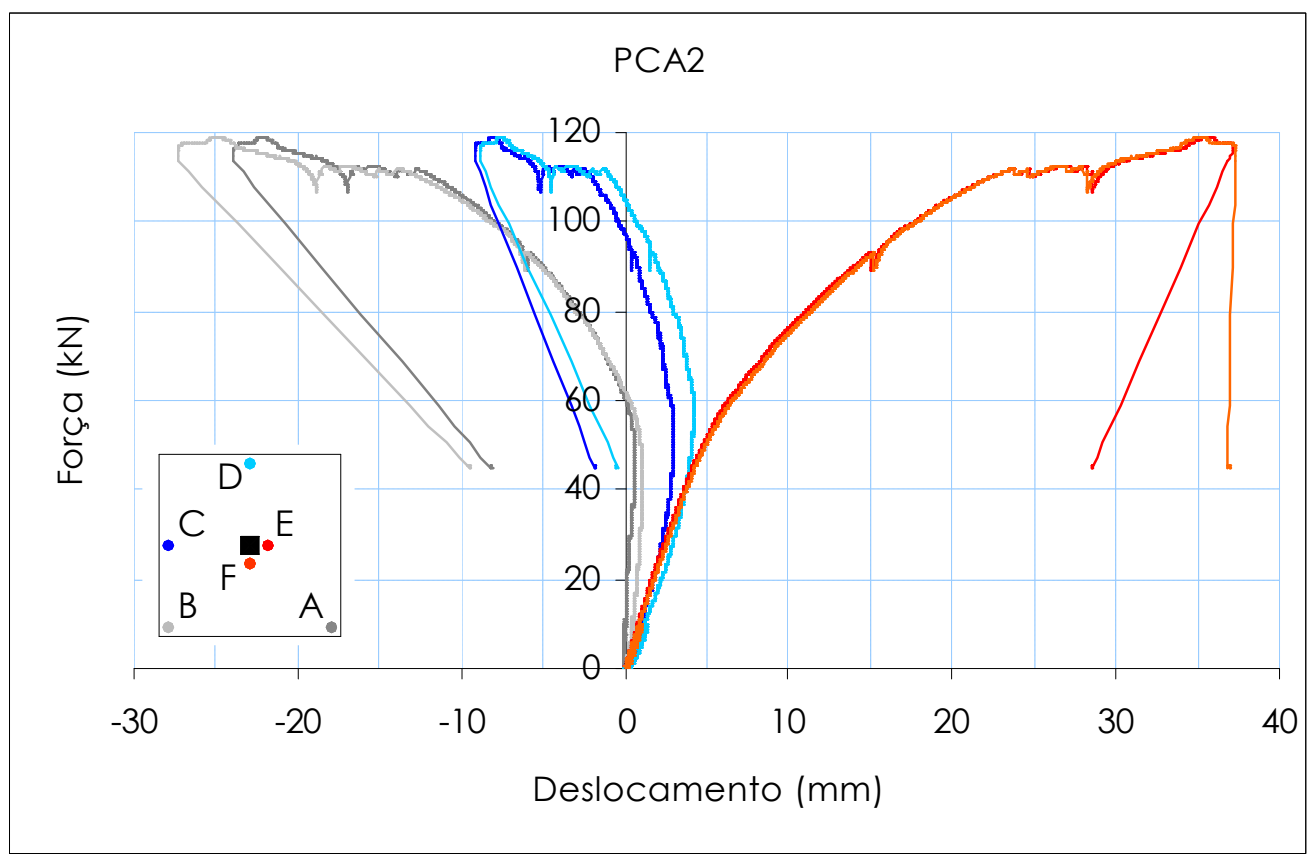

Figura 5.48 - Força - deslocamento na placa de concreto armado PCA2 - ensaio estático com deformação controlada 


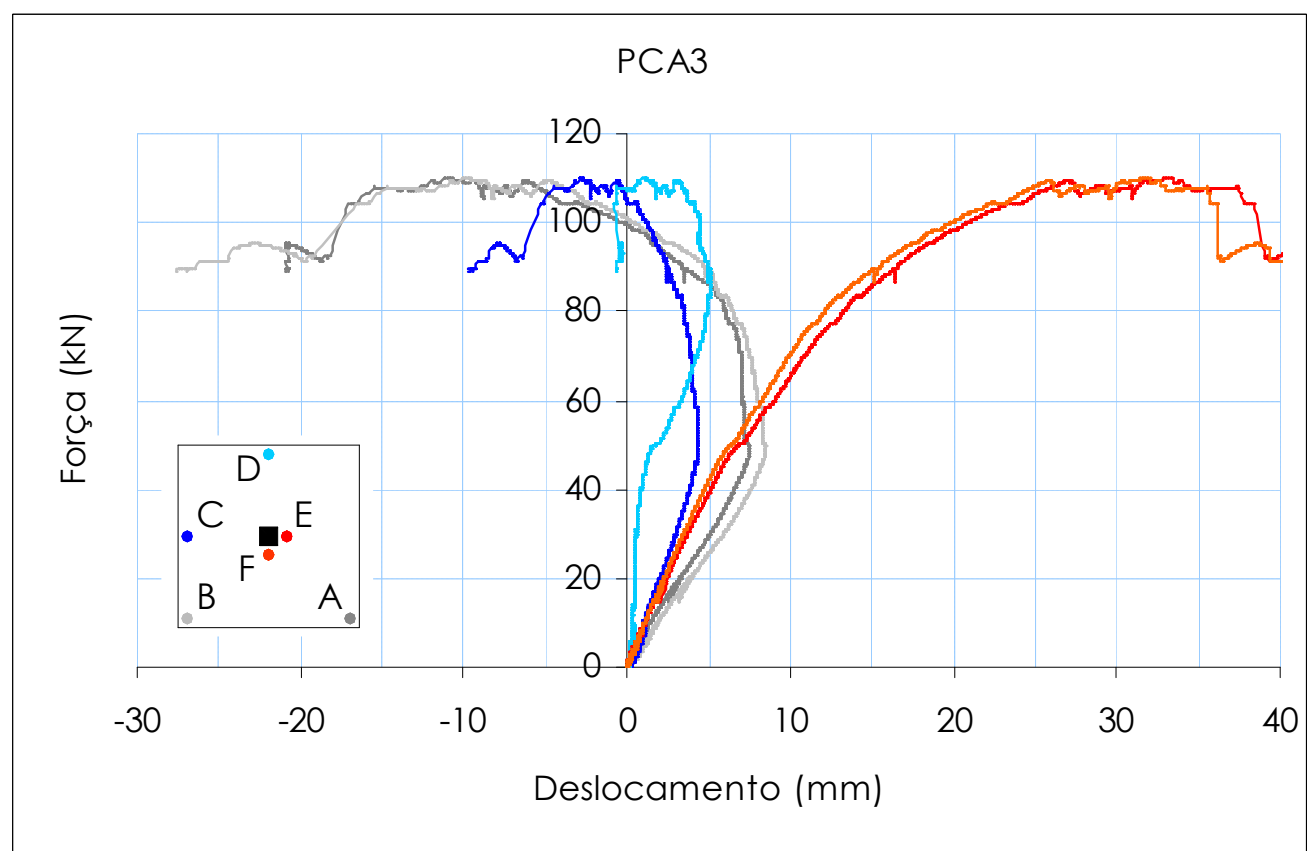

Figura 5.49 - Força - deslocamento na placa de concreto armado PCA3 - ensaio estático com deformação controlada

No gráfico da figura 5.50 são plotados os deslocamentos nos centros das três placas. Nesta figura nota-se que o modelo PCS1, diferente dos outros dois, apresenta um trecho convexo no início da curva. Isso se justifica por um assentamento da placa durante a execução do ensaio, sendo necessário portanto a correção da curva a fim de determinar a verdadeira rigidez inicial da placa, se esta estivesse perfeitamente apoiada sobre a base elástica. Essa correção é apresentada na figura 5.51.

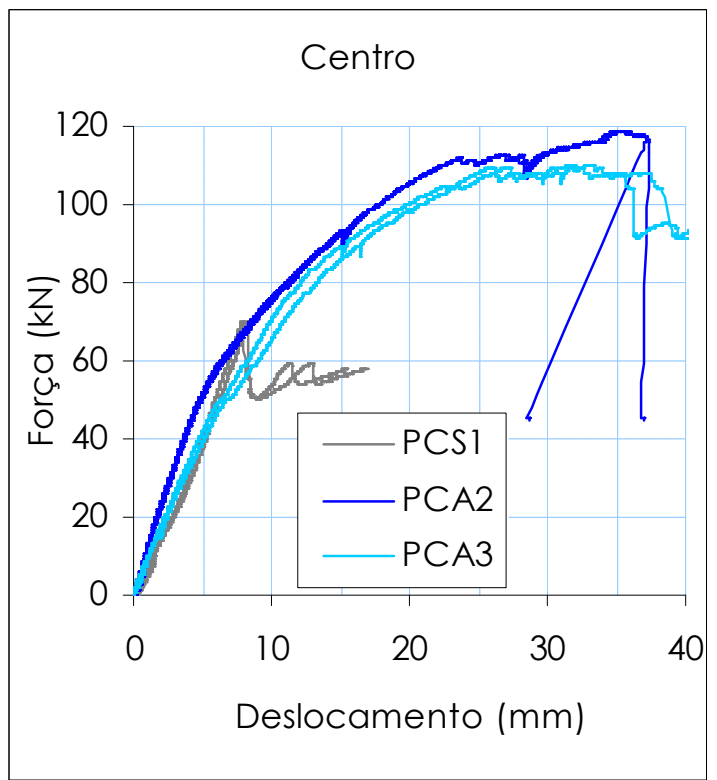

Figura 5.50 - Deslocamentos nos centros das placas nos ensaios estáticos

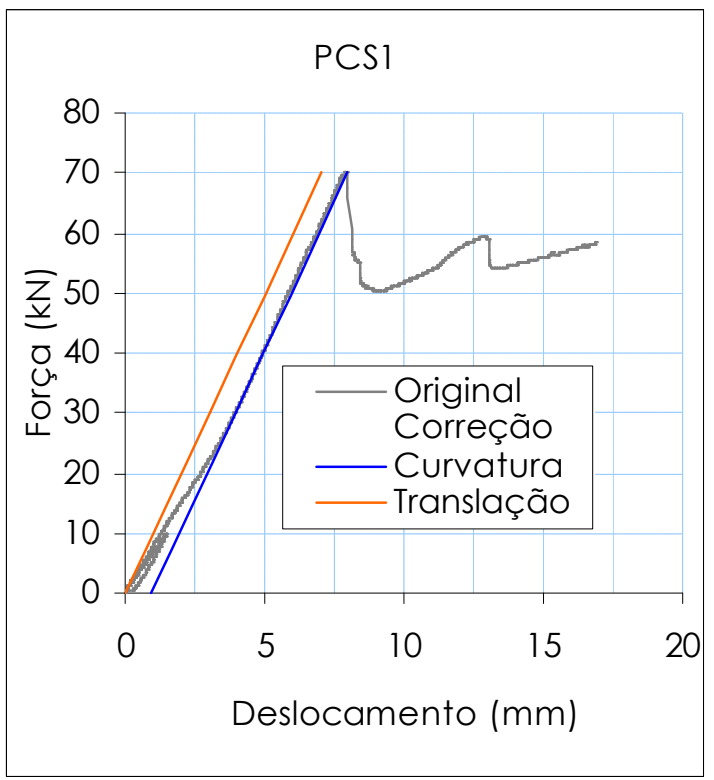

Figura 5.51 - Correção do gráfico força deslocamento para o modelo PCS 1 
A placa de concreto simples, como não poderia deixar de acontecer, rompe logo após o aparecimento da primeira fissura. As placas de concreto armado perdem rigidez após a fissuração do concreto, mas continuam absorvendo esforços até o aparecimento da fissura na superfície que ocorre com uma força aproximadamente $60 \%$ maior que a da placa de concreto simples. Um resumo das forças e deslocamentos dos modelos ensaiados com carregamento estático está apresentado na tabela 5.13.

Tabela 5.13 - Resumo dos resultados dos ensaios estáticos em placas

\begin{tabular}{ccccc}
\hline Modelo & $\begin{array}{c}\text { Força primeira } \\
\text { fissura }(\mathrm{kN})\end{array}$ & $\begin{array}{c}\text { Deslocamento } \\
\text { primeira fissura } \\
(\mathrm{mm})\end{array}$ & Força ruína $(\mathrm{kN})$ & $\begin{array}{c}\text { Deslocamento } \\
\text { ruína }(\mathrm{mm})\end{array}$ \\
\hline PCS1 & $\approx 70$ & 7,02 & 70,26 & 8,14 \\
PCA2 & $\approx 50$ & 4,84 & 118,98 & 35,51 \\
PCA3 & $\approx 50$ & 6,61 & 110,31 & 32,71 \\
\hline
\end{tabular}

Nos gráficos das figuras 5.52 e 5.53 são mostradas as deformações na armadura dos modelos PCA2 e PCA3.

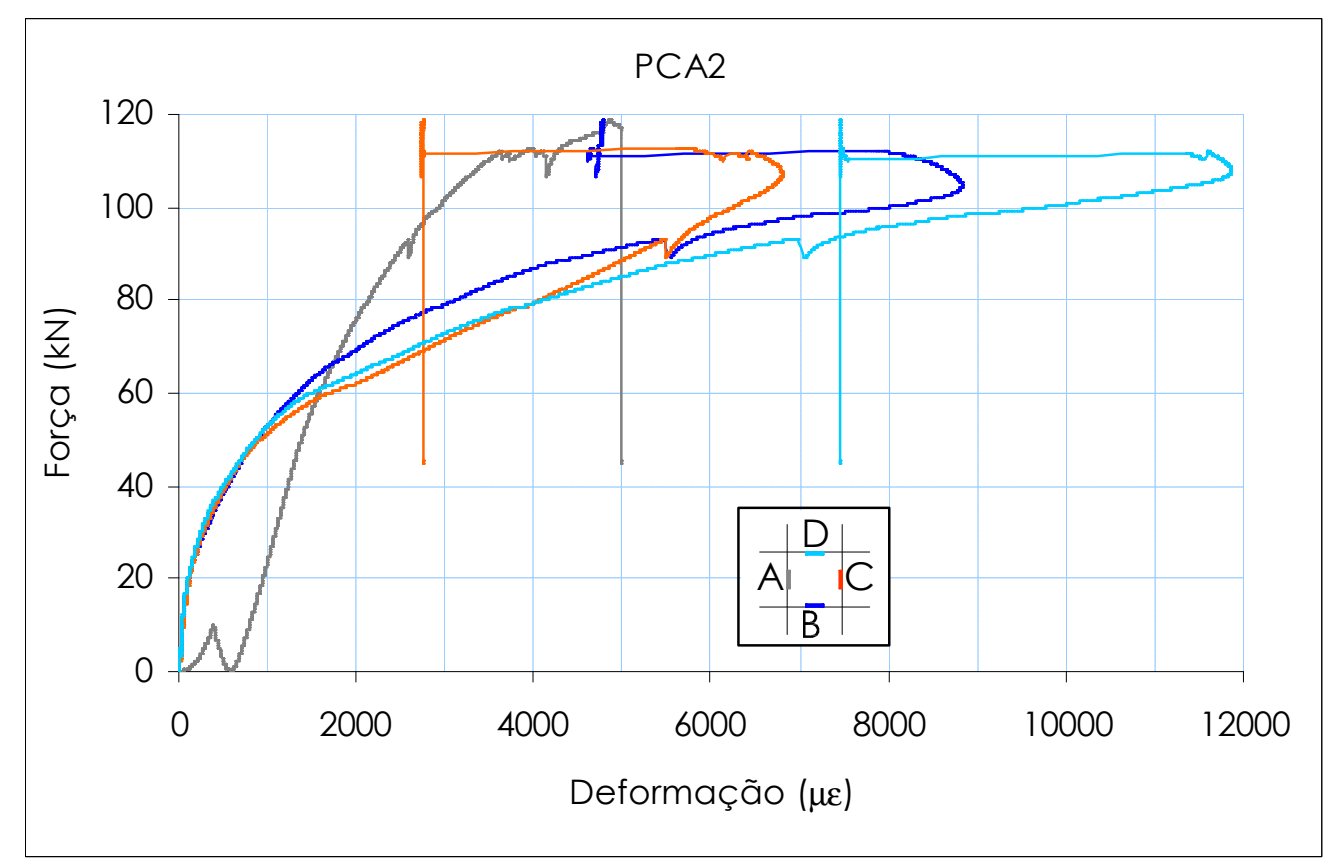

Figura 5.52 - Deformações na armadura do modelo PCA2 


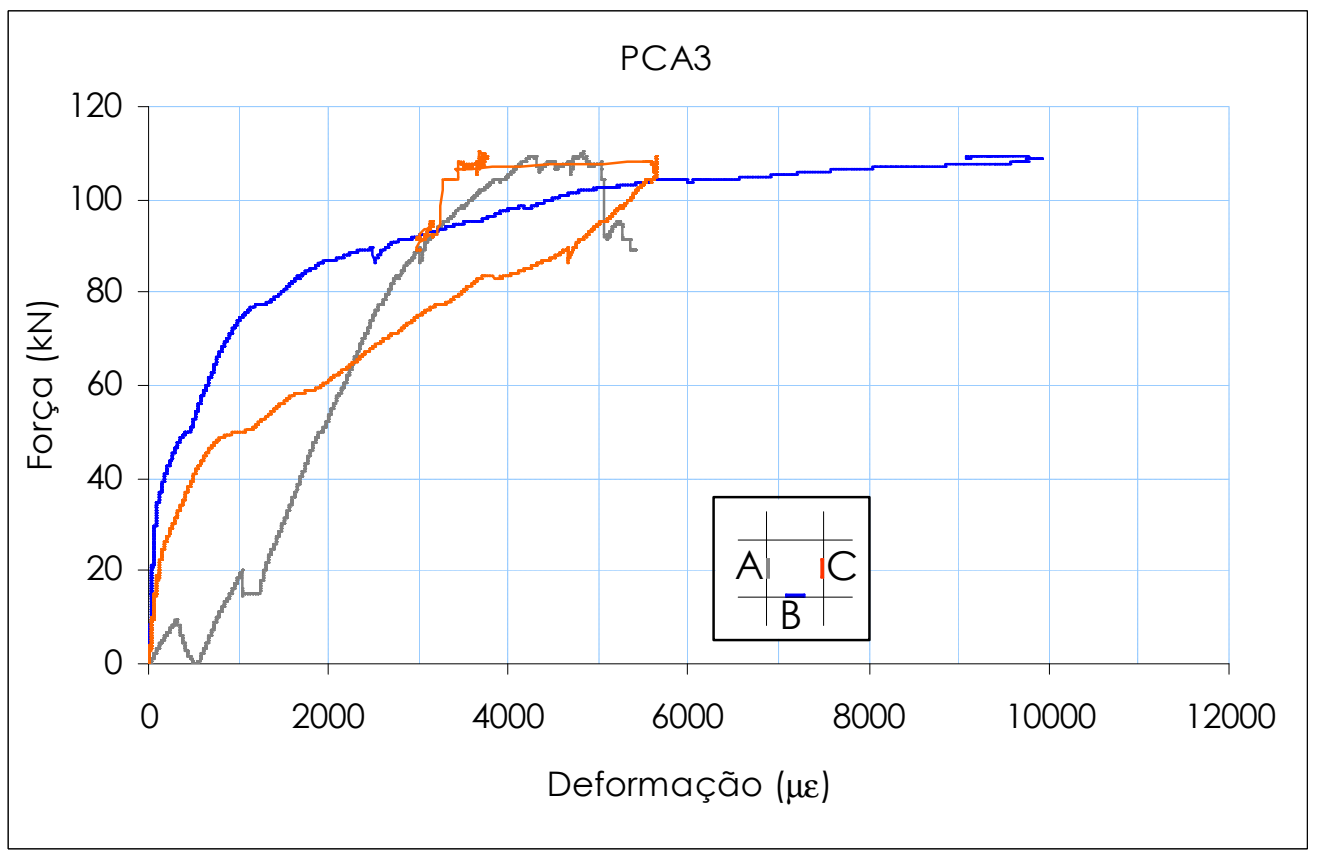

Figura 5.53 - Deformações na armadura do modelo PCA3

Um dos extensômetros do modelo PCA3 apresentou defeito e não foi possível efetuar as leituras.

Ao se propagarem as fissuras do modelo PCS1, a placa se dividiu em quatro partes, conforme é mostrado nas figuras 5.54 e 5.55. A ruptura ocorreu por flexão, nas duas direções.
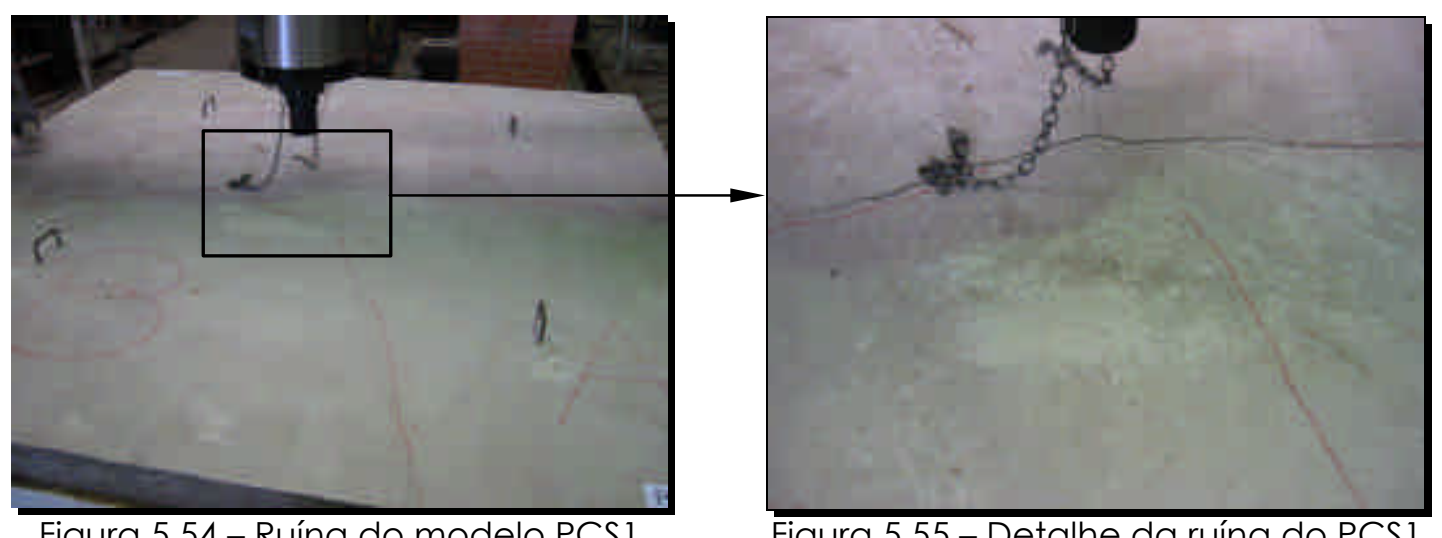

Figura 5.54 - Ruína do modelo PCS1 Figura 5.55 - Detalhe da ruína do PCS1

No modelo PCA2 as primeiras fissuras apareceram na face lateral, com a força de 68 kN, conforme é mostrado na figura 5.56. Quando a força atingiu 108 kN, houve a formação de uma fissura circunferencial mostrada na figura 5.57, a aproximadamente $40 \mathrm{~cm}$ da face da área de aplicação da força, mas ainda se observava um acréscimo na força. Com a força de $118 \mathrm{kN}$ houve o afundamento da placa metálica, mostrado na figura 5.58, tangente à face da área de aplicação da força. A partir desse instante, o modelo parou de receber acréscimo 
de força. A figura 5.59 mostra a configuração das fissuras na face inferior da placa.
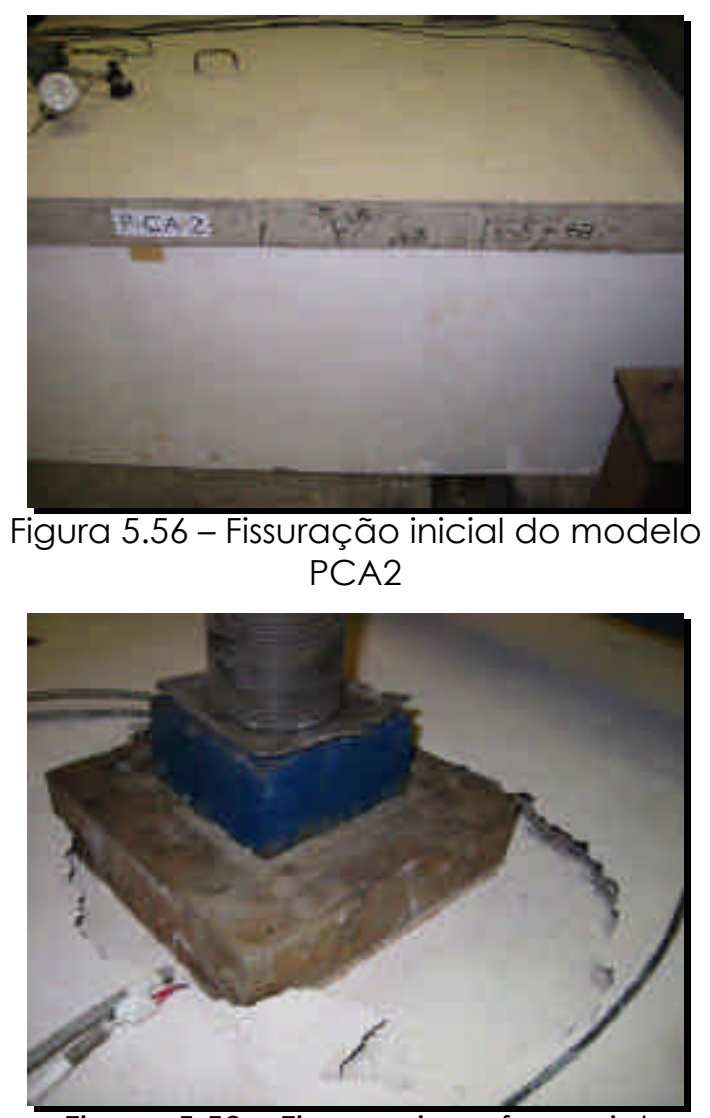

Figura 5.58 - Fissura circunferencial adjacente à face da força, modelo PCA2

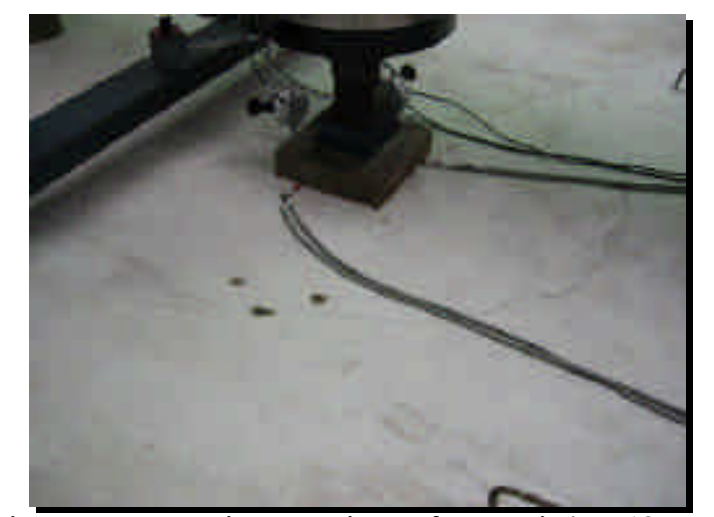

Figura 5.57 - Fissura circunferencial a $40 \mathrm{~cm}$ da face da força, modelo PCA2

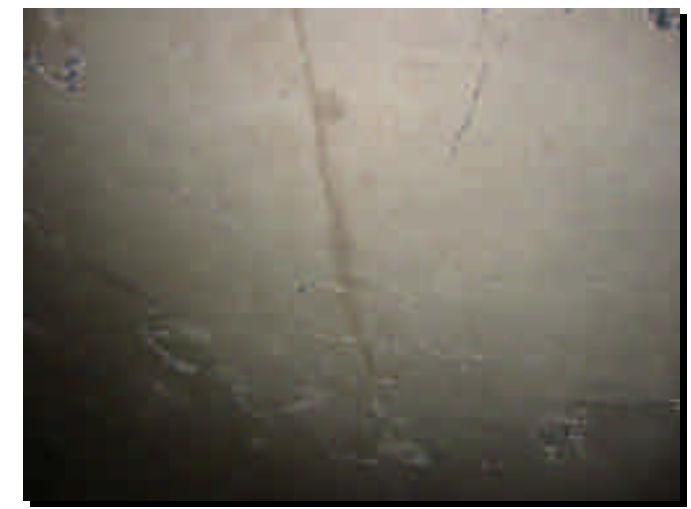

Figura - 5.59 - Configuração das fissuras na face inferior, modelo PCA2

No modelo PCA3 o aparecimento das fissuras nas laterais ocorreu nas forças marcadas na figura 5.60. Quando a força atingiu $108 \mathrm{kN}$, apareceu na superfície a fissura circunferencial, a $40 \mathrm{~cm}$ da face da força - figura 5.61. A placa deixou de absorver acréscimo de força quando a placa se dividiu em duas devido à fissura de flexão - figura 5.62. A configuração das fissuras na face inferior da placa está mostrada na figura 5.63 .

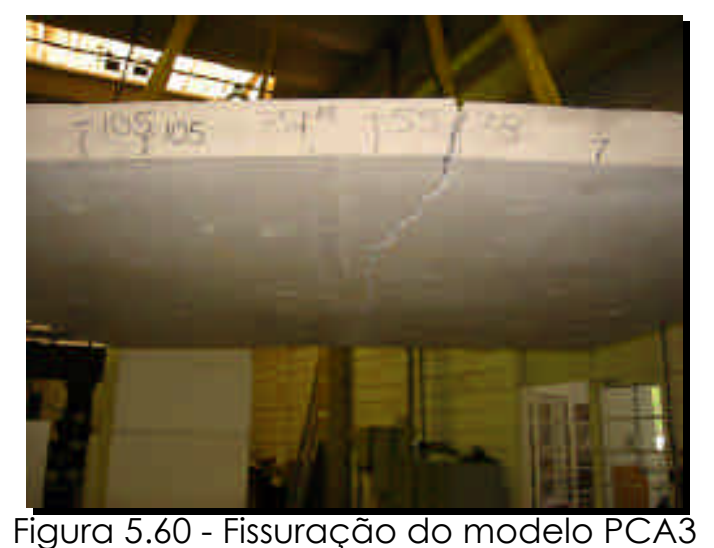

Figura 5.60 - Fissuração do modelo PCA3

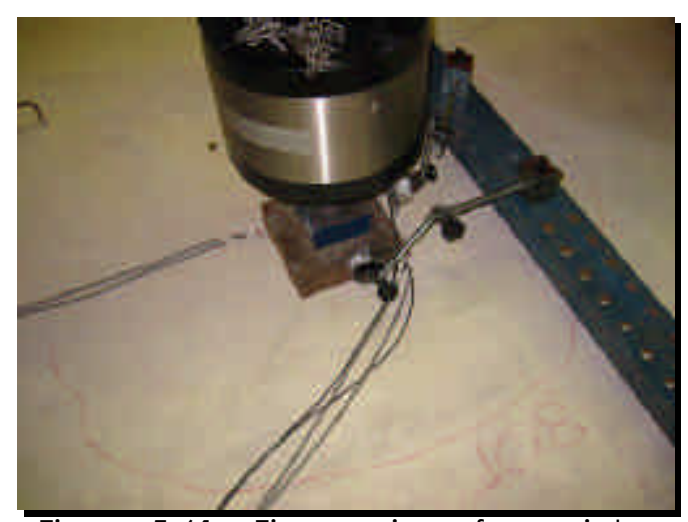

Figura 5.61 - Fissura circunferencial a $40 \mathrm{~cm}$ da face da força, modelo PCA3 


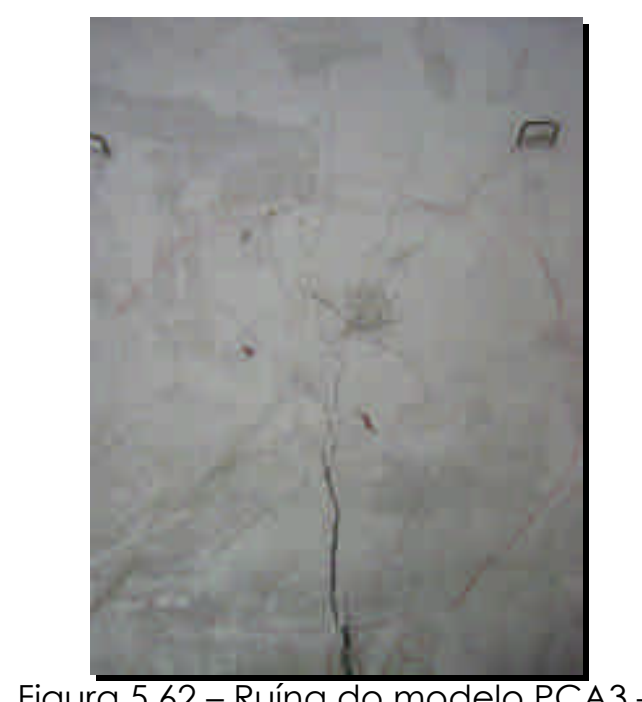

Figura 5.62 - Ruína do modelo PCA3 face superior

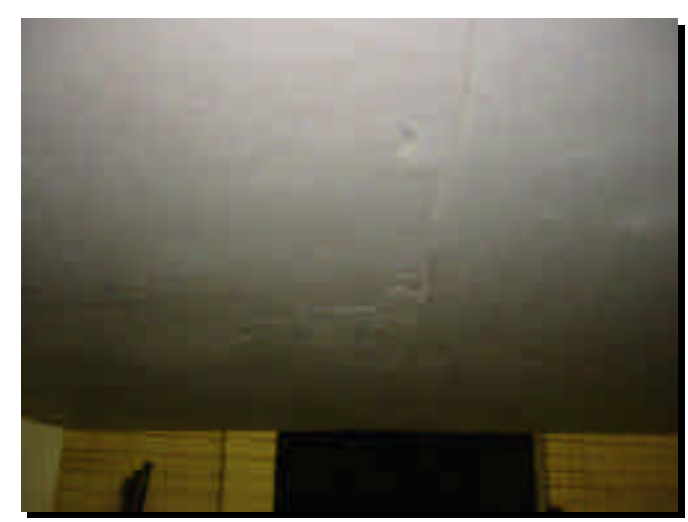

Figura 5.63 - Configuração das fissuras na face inferior, modelo PCA3

c. Ensaios de fadiga - placas

Foram ensaiadas três placas de concreto armado à fadiga: PCA4, PCA5 e PCA6.

\section{PCA4}

No ensaio do modelo PCA4 foi aplicado inicialmente um carregamento monotônico até a força de 45 kN. A partir daí procurou-se aplicar uma oscilação de $\pm 40 \mathrm{kN}$, buscando atingir a força máxima de $80 \%$ da força última atingida no ensaio estático do modelo PCA3. A freqüência do carregamento era de 0,5 Hz e inicialmente conseguiram-se as forças máxima e mínima de 72 kN e 18 kN, por aproximadamente dez ciclos. Logo em seguida a amplitude foi aumentada para $85 \mathrm{kN}(77,3 \%)$ e $8 \mathrm{kN}$ (7,3\%). Foram feitas leituras até 215 ciclos. A leitura foi interrompida e a freqüência alterada para 1,156 Hz. As forças máxima e mínima foram mantidas. Aos 1000 ciclos aumentou-se a freqüência para 1,262 Hz. A força máxima passou a ser de 85,3 kN $(77,5 \%)$ e a mínima se manteve em 8 kN. Foram realizadas leituras de aproximadamente dez ciclos a cada 500 ciclos de carregamento. Quando o ensaio estava com 2970 ciclos, houve uma interrupção. O sistema foi religado com freqüência de $0,5 \mathrm{~Hz}$, força máxima de $85 \mathrm{kN}$ e mínima de 7,8 kN. Foi realizada leitura aos 3000 ciclos. Ajustou-se a freqüência para 1,266 Hz, com força máxima de 85,2 kN (77,5\%) e mínima de 6,7 kN (6,1\%). As leituras continuaram a ser efetuadas a cada 500 ciclos até os 10070 ciclos, quando houve nova interrupção, por causa do término do expediente do laboratório. No reinício do ensaio foi aplicada freqüência de $1,26 \mathrm{~Hz}$, força máxima de $84,65 \mathrm{kN}$ (77\%) e mínima de 6,9 kN (6,3\%). Foram efetuadas leituras a cada 500 ciclos até os 
15000 ciclos. A partir daí foram realizadas leituras a cada 1000 ciclos. Aos 20070 ciclos, ouviu-se o primeiro estalo na armadura. Ocorreram novos estalos aos 25000 , 26070, 27000, 27650, 27720, 27740, 27770, 27970 ciclos, quando apareceu uma fissura de flexão na superfície da placa, mostrada na figura 5.64 .

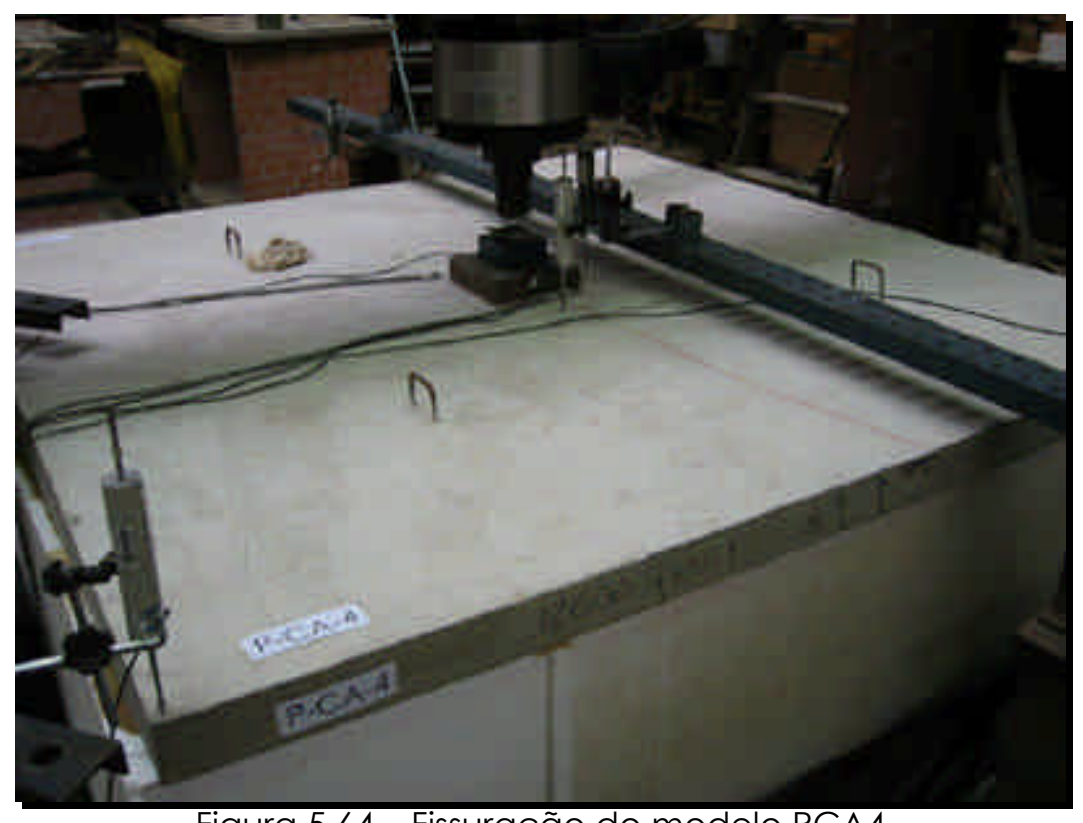

As primeiras fissuras apareceram logo no início do carregamento. Outras se desenvolveram ao longo do ensaio. $\bigcirc$ número de ciclos no qual se observou o aparecimento de cada fissura está marcado na lateral da placa.

Figura 5.64 - Fissuração do modelo PCA4

Nas figuras 5.65, 5.66 e 5.67 são traçados os deslocamentos medidos nos cantos, nas bordas e próximos ao centro do modelo PCA4.

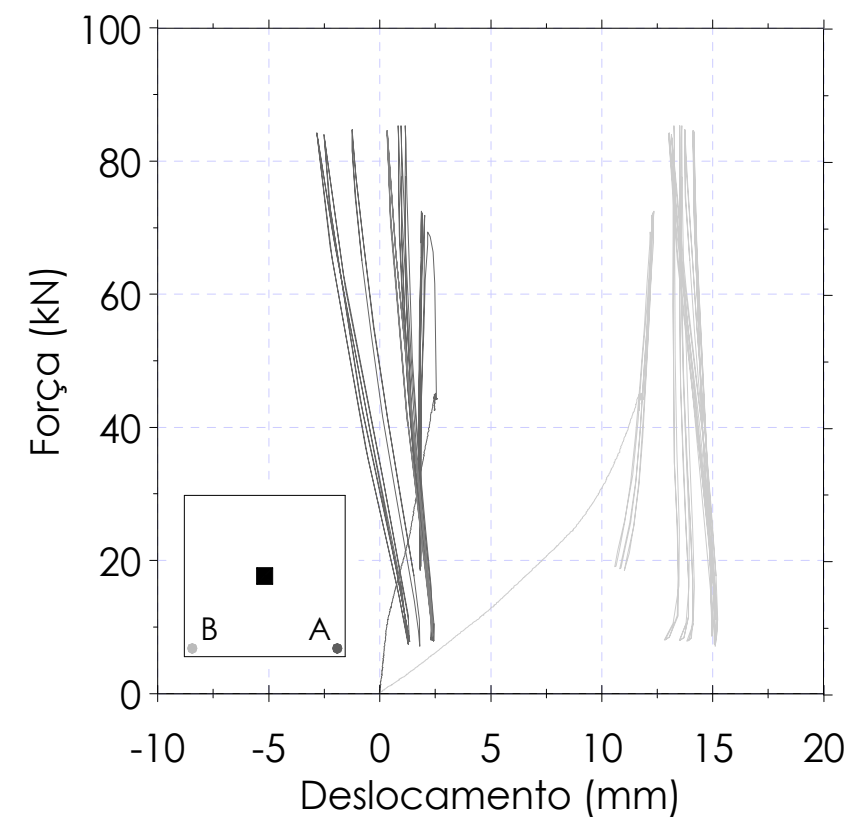

Figura 5.65 - Diagrama força - deslocamentos nos cantos da placa PCA4 


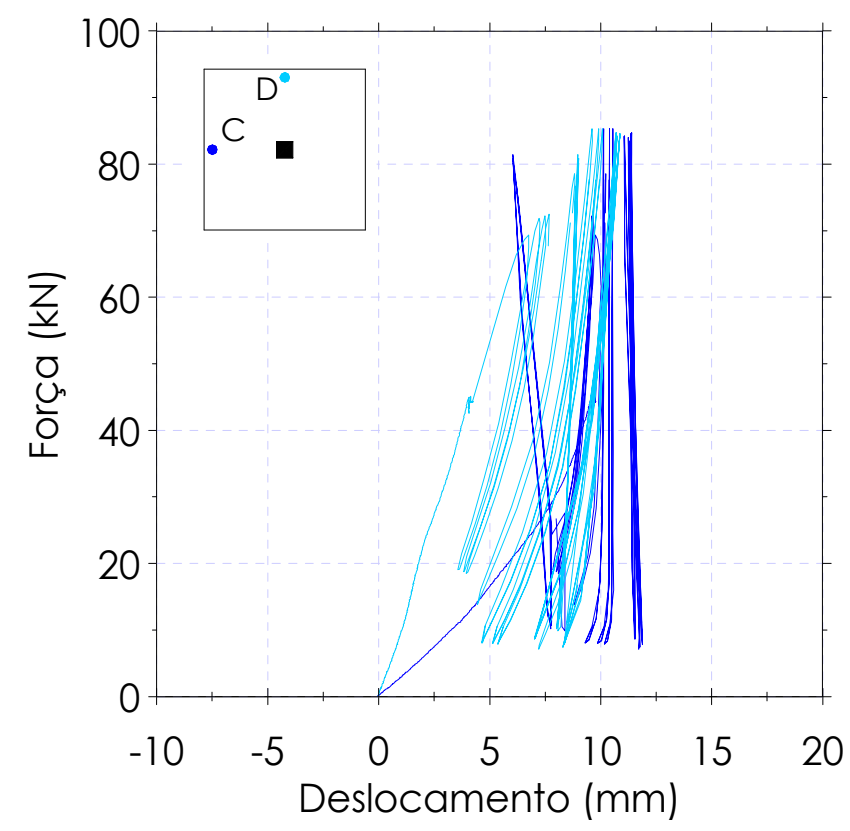

Figura 5.66 - Diagrama força - deslocamentos nas bordas da placa PCA4

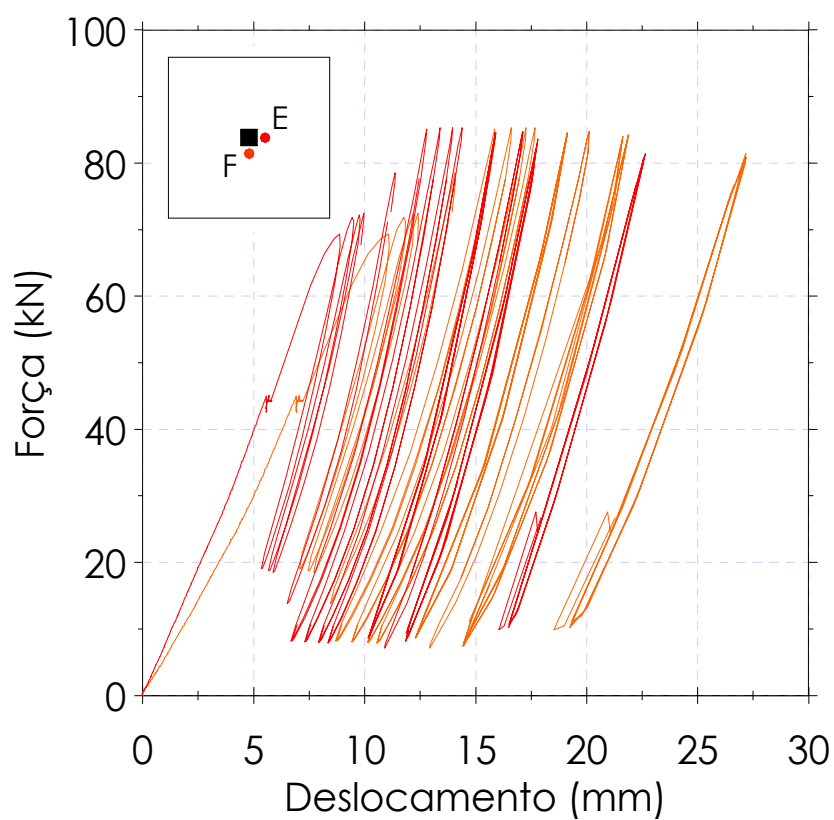

Figura 5.67 - Diagrama força - deslocamentos próximos ao centro da placa PCA4

Nas figuras 5.68, 5.69, 5.70 e 5.71 são mostrados os gráficos força - deformação na armadura medidas pelos extensômetros A, C, B e D, respectivamente. Os extensômetros B e D foram colados em fios da tela soldada, posicionados paralelos à viga do pórtico de reação, enquanto $A$ e $C$ eram perpendiculares a eles. 


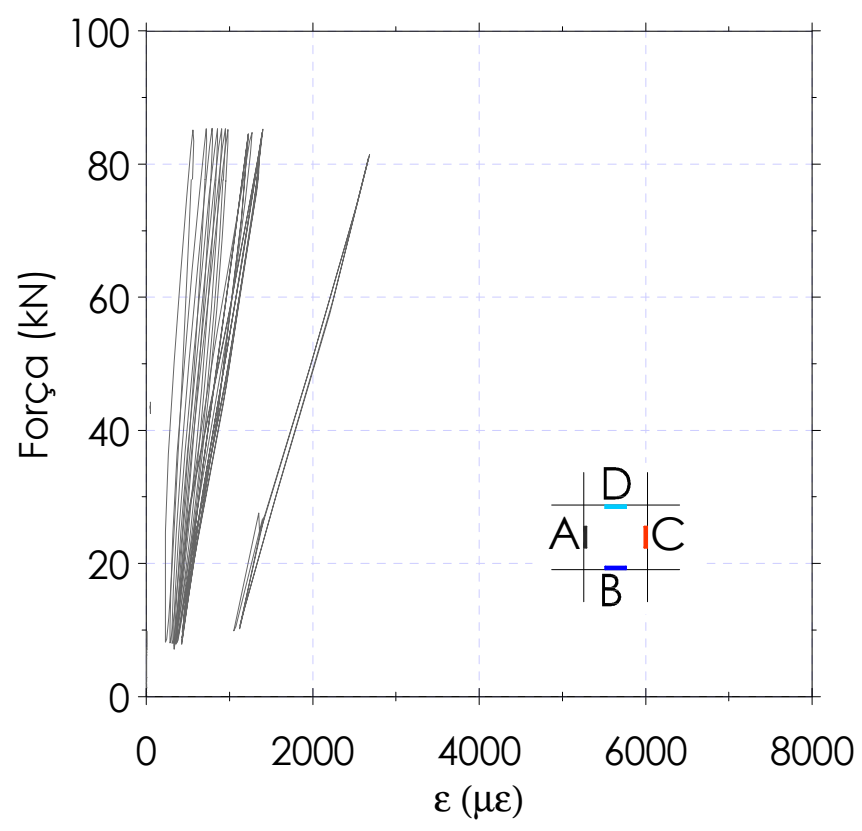

Figura 5.68 - Diagrama força - deformação na armadura, extensômetros A do modelo PCA4

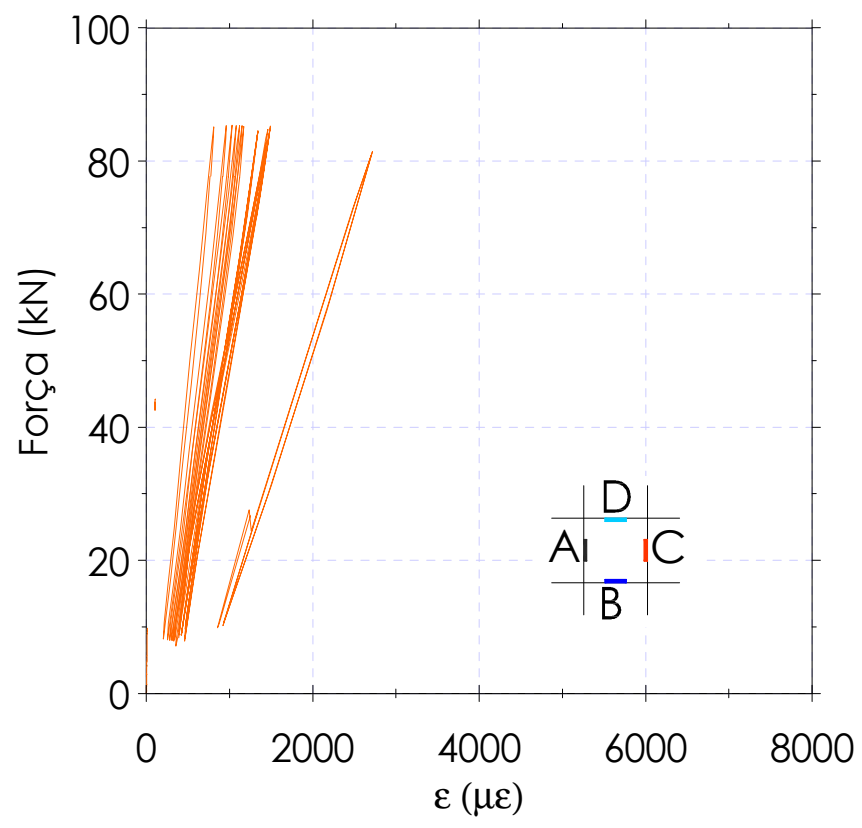

Figura 5.69 - Diagrama força - deformação na armadura, extensômetros $C$ do modelo PCA4 


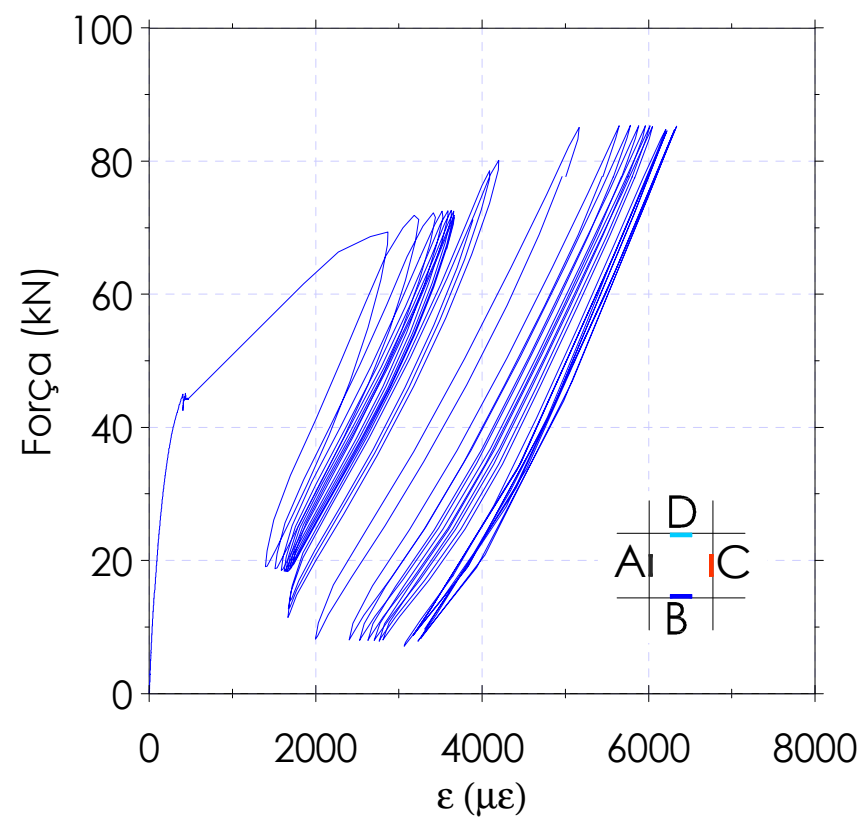

Figura 5.70 - Diagrama força - deformação na armadura, extensômetros B do modelo PCA4

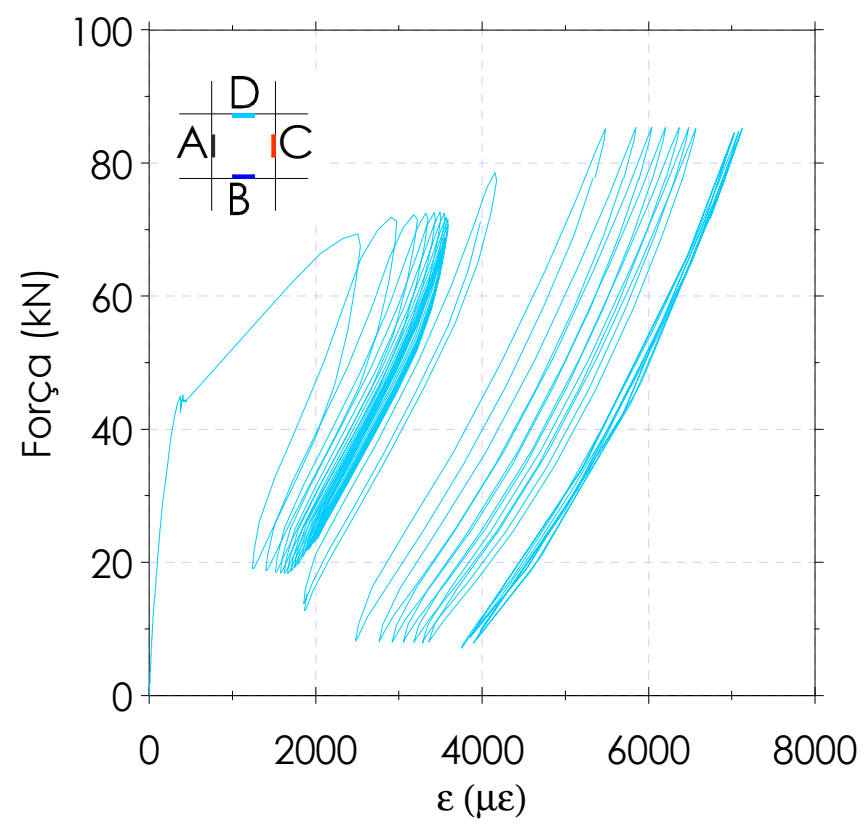

Figura 5.71 - Diagrama força - deformação na armadura, extensômetros D do modelo PCA4

Comparando as figuras 5.68 a 5.71 percebe-se que o modelo apresentou uma direção preferencial para as deformações, paralela à viga do pórtico. Assim sendo, o modelo não se comportou exatamente como uma placa uniformemente apoiada, com força no centro, pois neste caso as deformações deveriam ser iguais nas duas direções. Explica-se esse problema por defeitos na geometria e no apoio do modelo que provocaram o aparecimento das primeiras fissuras em apenas uma direção. 


\section{$\underline{\text { PCA5 }}$}

Para o início do ensaio do modelo PCA5 foi aplicado um carregamento monotônico de 40 kN. Lendo os dados a cada segundo, aplicou-se o carregamento cíclico com freqüência de $0,5 \mathrm{~Hz}$, força máxima de $68 \mathrm{kN}(62 \%)$ e mínima de 11 kN (10\%). Ajustou-se a freqüência de leitura para uma a cada dez segundos e as forças para $76 \mathrm{kN}$ (69\%) e 6,5 kN (5,9\%). Atingidos os 100 ciclos, a freqüência de carregamento foi alterada para $1 \mathrm{~Hz}$, com força máxima de $75 \mathrm{kN}(68 \%)$ e mínima de 8,5 kN (7,7\%). Atingidos os 500 ciclos, houve novo ajuste, com freqüência de 1,5 Hz, forças de $75 \mathrm{kN}$ e $4,7 \mathrm{kN}$ (4,3\%). A leitura era feita a cada 500 ciclos até atingir 2000. A partir daí passou-se a registrar a leitura a cada 1000 ciclos. Aos 10000 ciclos ajustou-se novamente a força, mantendo a freqüência de 1,5 Hz, forças de 75,11 (68,3\%) e 4,73 kN (4,3\%). Novo ajuste aos 20000 ciclos, com freqüência de 1,5 Hz, forças de 75,05 kN (68,2\%) e 5,07 kN (4,6\%). Aos 34000 ciclos a freqüência foi alterada para $1,8 \mathrm{~Hz}$ e as forças ficaram em $75,10 \mathrm{kN}(68,3 \%)$ e 4,8 kN (4,4\%). A leitura passou a ser feita a cada 2000 ciclos. A partir dos 53000 ciclos, a leitura voltou a ser registrada a cada 500 ciclos, até os 57200. Os estrondos na armadura foram ouvidos aos 40000, 53000 e 55600 ciclos. A primeira fissura chegou à superfície aos 56175 ciclos, mas a placa continuou resistindo ao carregamento até os 58615 ciclos, quando a força não estabilizou mais. A figura 5.72 mostra o aparecimento de fissuras em uma das bordas do modelo. Na figura 5.73 pode ser vista a fissuração da face inferior da placa, após o término do ensaio.

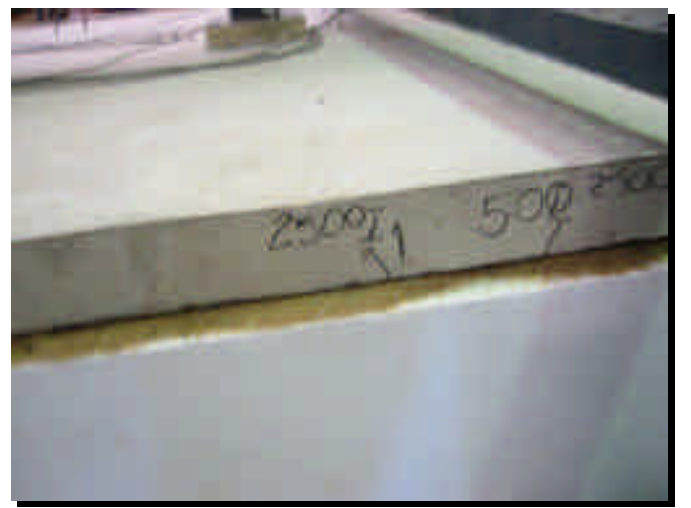

Figura 5.72 - Abertura de fissuras na borda do modelo PCA5
Assim como no modelo PCA4, houve abertura de fissuras logo nos primeiros ciclos. Com o decorrer do carregamento essas fissuras aumentavam de comprimento no sentido da face superior. 


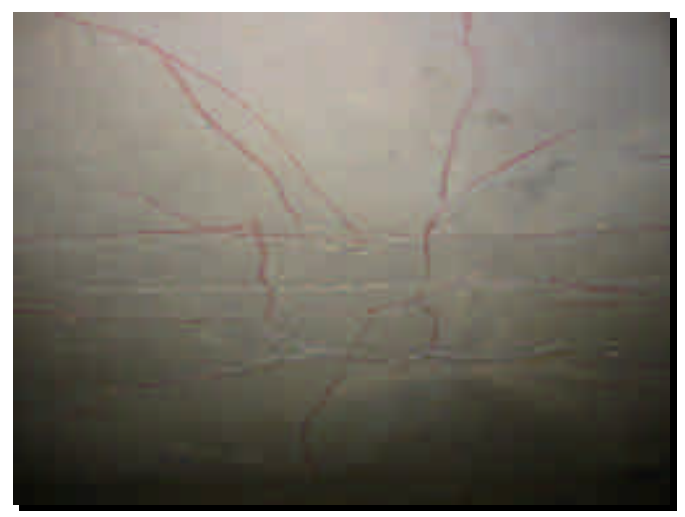

No modelo PCA5 houve a formação de fissuras de flexão em todas as direções, crescendo a partir do centro em direção às bordas. Também se observa a formação de fissuras circunferenciais, em torno da área central da placa.

Figura 5.73 - Fissuração na face inferior no modelo PCA5

Nas figuras 5.74, 5.75 e 5.76 são traçados os deslocamentos medidos nos cantos, nas bordas e próximos ao centro do modelo PCA5.

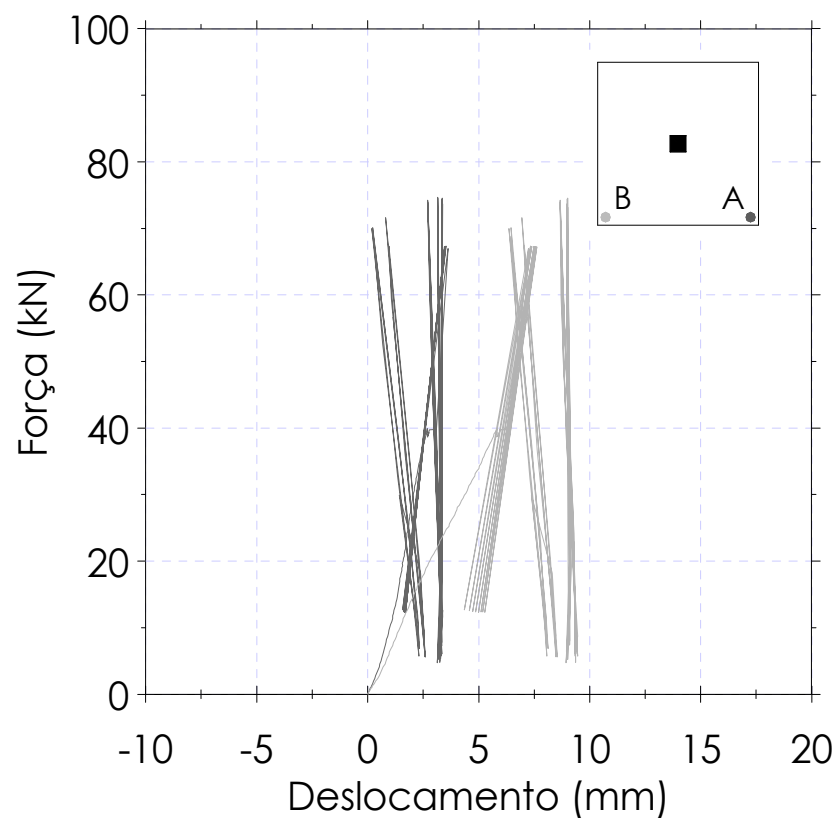

Figura 5.74 - Diagrama força - deslocamentos nos cantos da placa PCA5 


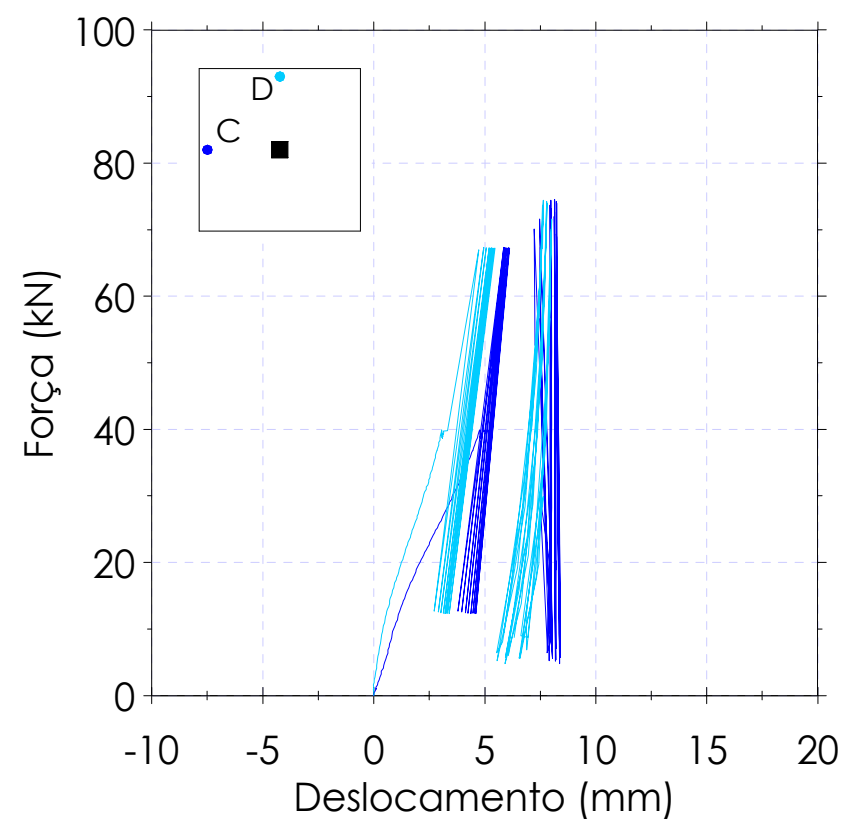

Figura 5.75 - Diagrama força - deslocamentos nas bordas da placa PCA5

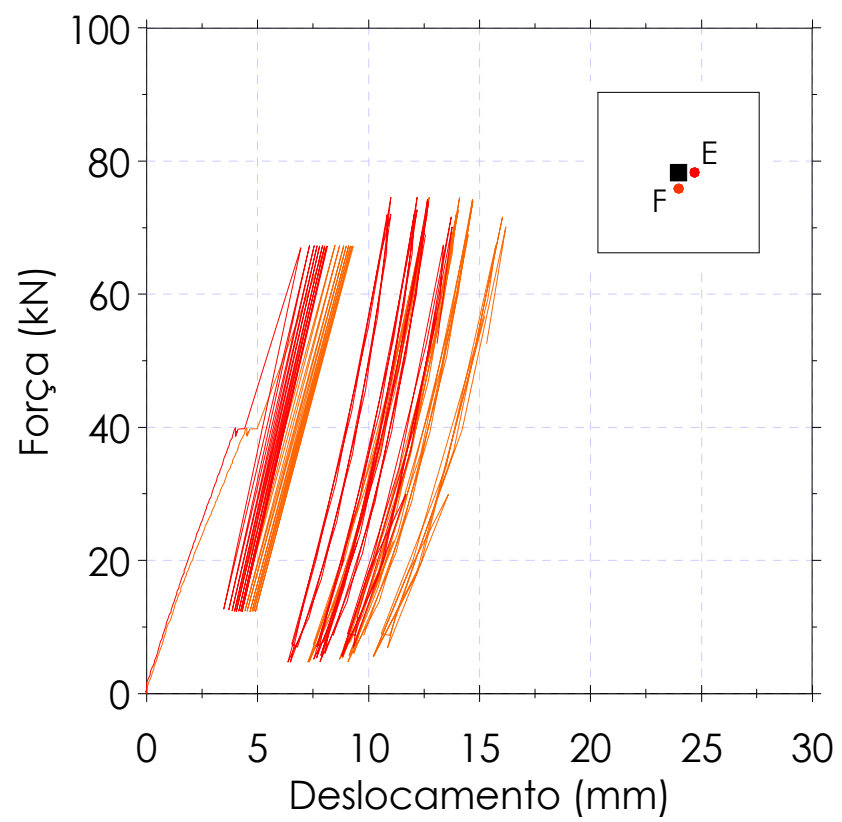

Figura 5.76 - Diagrama força - deslocamentos próximos ao centro da placa PCA5

Nas figuras 5.77 a 5.80 pode-se perceber que neste modelo também houve uma direção em que as deformações foram maiores que na outra, mas com uma diferença significativamente inferior à do modelo PCA4. Verifica-se portanto que o modelo PCA5 apresentou um comportamento de placa melhor que o anterior, distribuindo as fissuras e as deformações em todas as direções. 


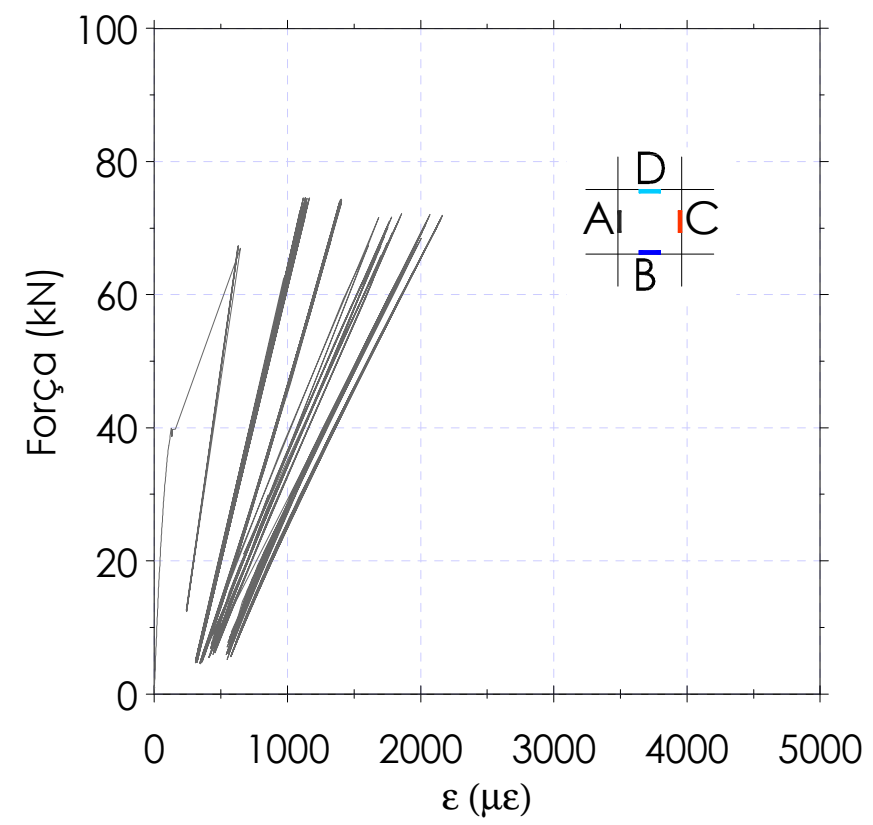

Figura 5.77 - Diagrama força - deformação na armadura, extensômetros A do modelo PCA5

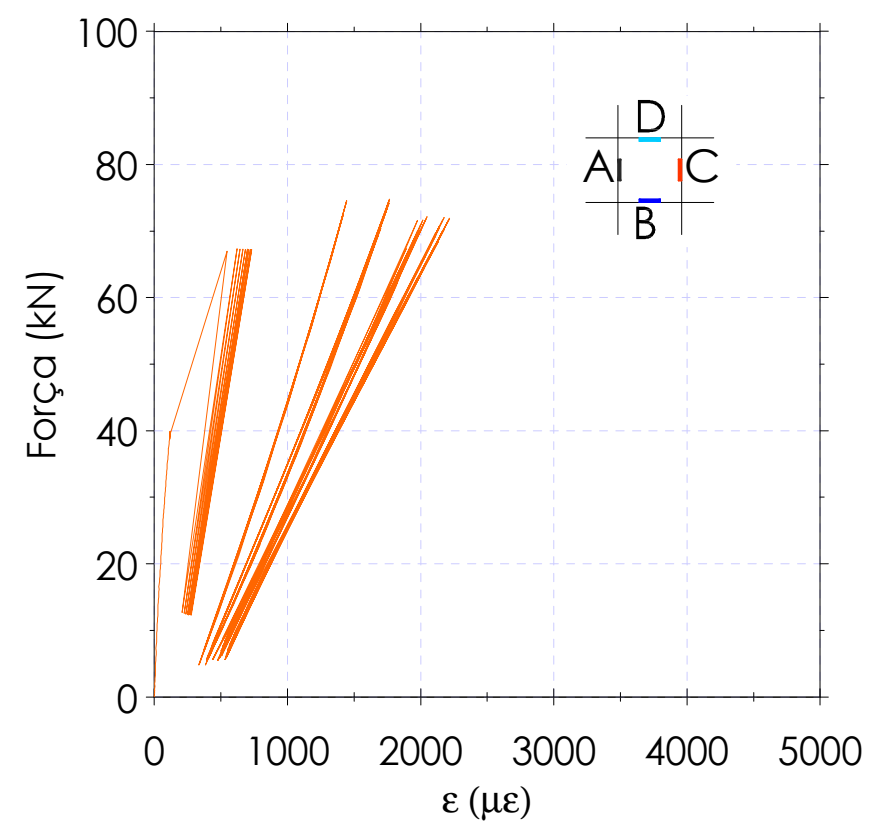

Figura 5.78 - Diagrama força - deformação na armadura, extensômetros C do modelo PCA5 


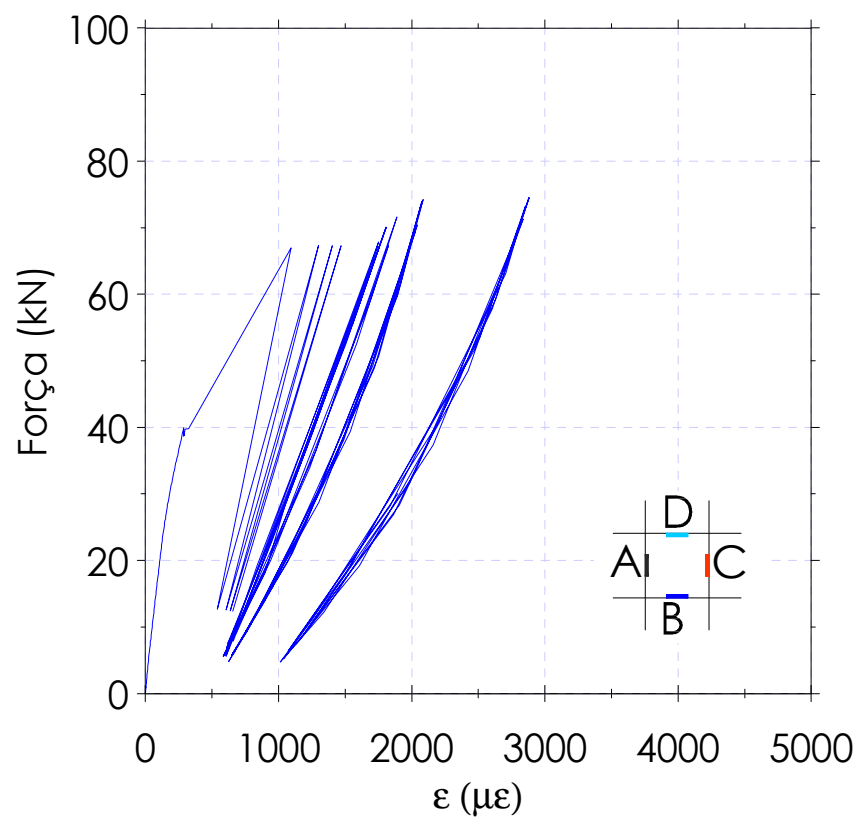

Figura 5.79 - Diagrama força - deformação na armadura, extensômetros B do modelo PCA5

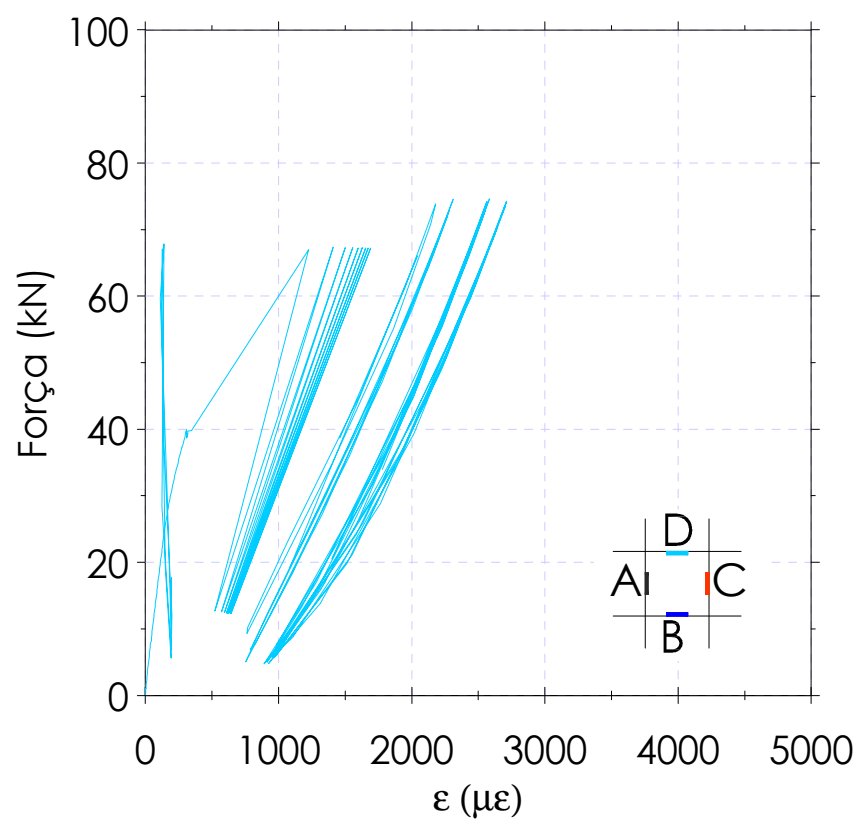

Figura 5.80 - Diagrama força - deformação na armadura, extensômetros D do modelo PCA5

A inclinação da curva da força x deformação do aço diminui com o aumento do número de ciclos.

\section{$\underline{\text { PCA6 }}$}

Para início do ensaio do modelo PCA6 aplicou-se um carregamento monotônico de $47,5 \mathrm{kN}$. Com uma freqüência de $0,5 \mathrm{~Hz}$ foi introduzido o carregamento repetido, com força máxima de 95,16 kN e mínima de 3,8 kN, até 23 ciclos quando 
houve uma interrupção no ensaio. Iniciou-se novamente com $0,5 \mathrm{~Hz}$, força máxima de 90,31 kN e mínima de 5,15 kN, registrando as leituras até 70 ciclos. Registraramse novamente aos 100 e 200 ciclos, quando houve uma pequena alteração da força mínima para 5,35 kN. Registraram-se as leituras a cada 250 ciclos até os 2500 . Foi alterada a freqüência para $0,60 \mathrm{~Hz}$, com forças de 90,3 kN e 5,2 kN. A partir daí foram feitas leituras a cada 500 ciclos até 20500. O primeiro barulho nos fios da armadura foi ouvido aos 19700 ciclos. Houve nova interrupção no ensaio aos 20662 ciclos. Reiniciou-se com freqüência de 0,78 Hz e forças de 90,37 kN e 4,9 kN. Foram efetuadas leituras aos 21000, 21500, 22000. Aos 21500 ciclos apareceu a fissura circunferencial, mas a placa continuava recebendo força. Após outra interrupção aplicaram-se as forças de $90,3 \mathrm{kN}(82,1 \%)$ e $5,0 \mathrm{kN}(4,5 \%)$ com uma freqüência de $0,8 \mathrm{~Hz}$, efetuando a leitura aos 22400 e 22600 ciclos. Houve afundamento da placa metálica e a força se tornou instável aos 22880 ciclos. Nas figuras 5.81 a 5.83 pode-se ver a formação de fissuras no ensaio do modelo PCA6.

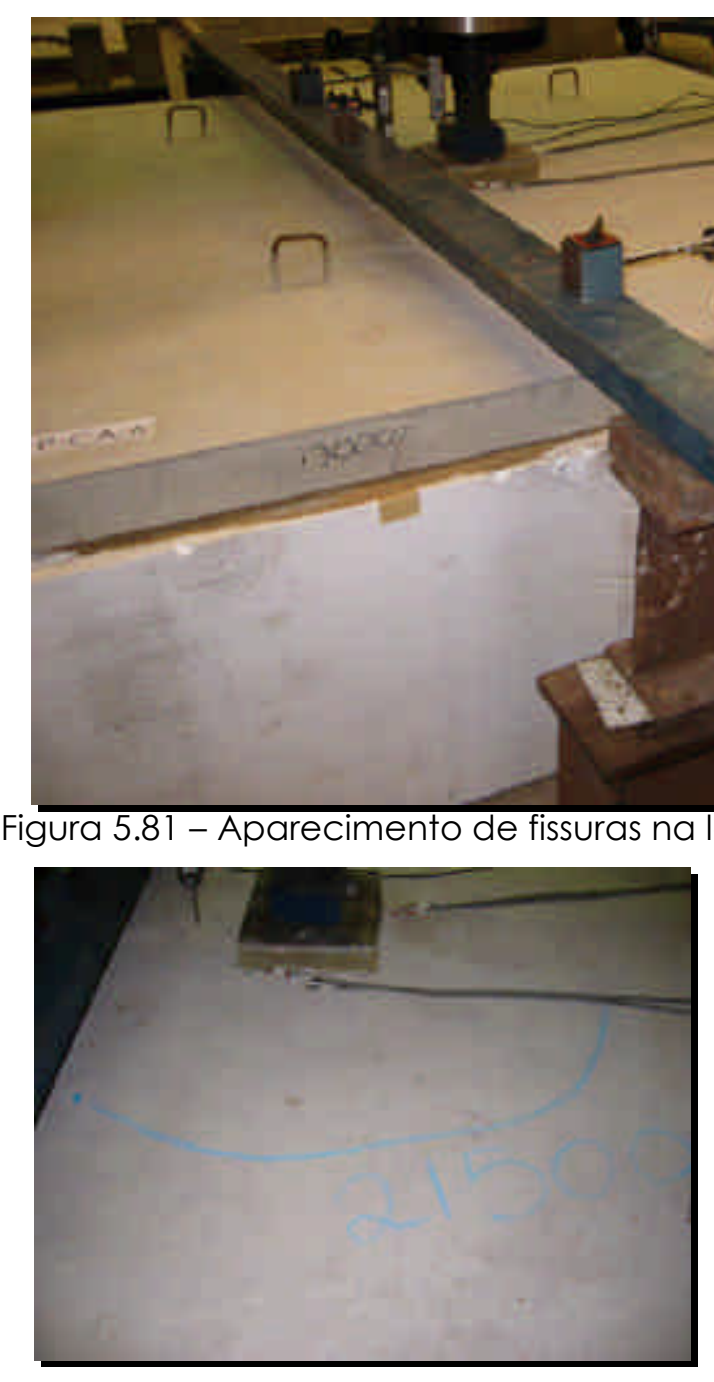

Figura 5.82 - Aparecimento do círculo a $40 \mathrm{~cm}$ da face da placa metálica
As primeiras fissuras apareceram logo nos primeiros ciclos. Novas fissuras se desenvolviam com o decorrer do carregamento. 
Nas figuras 5.84, 5.85 e 5.86 são mostrados os deslocamentos medidos no modelo PCA6.

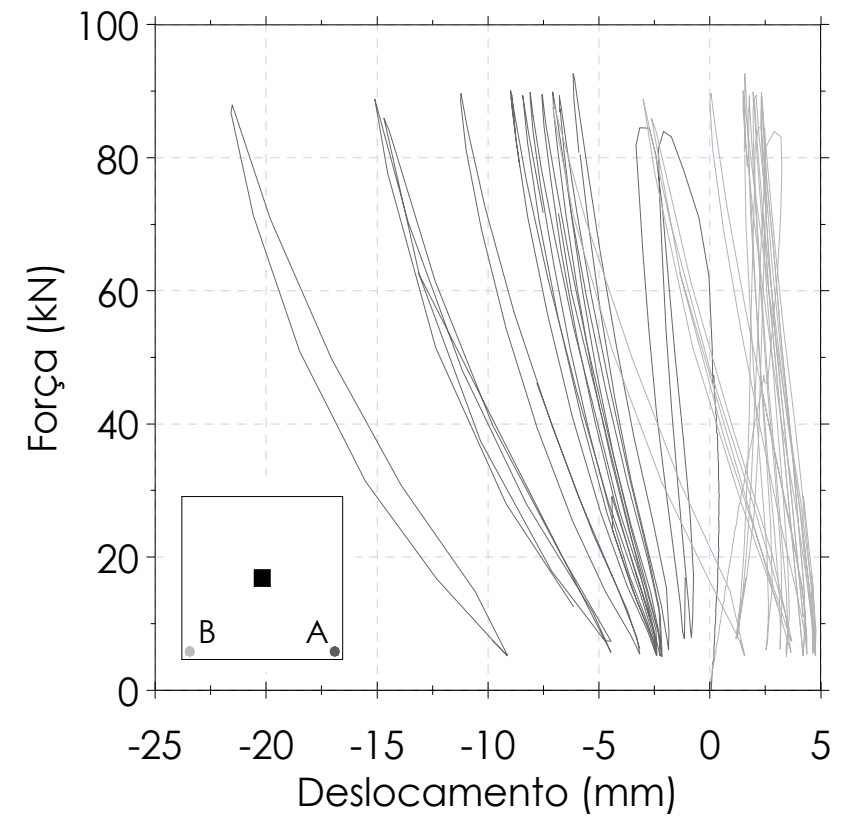

Figura 5.84 - Diagrama força - deslocamentos nos cantos da placa PCA6

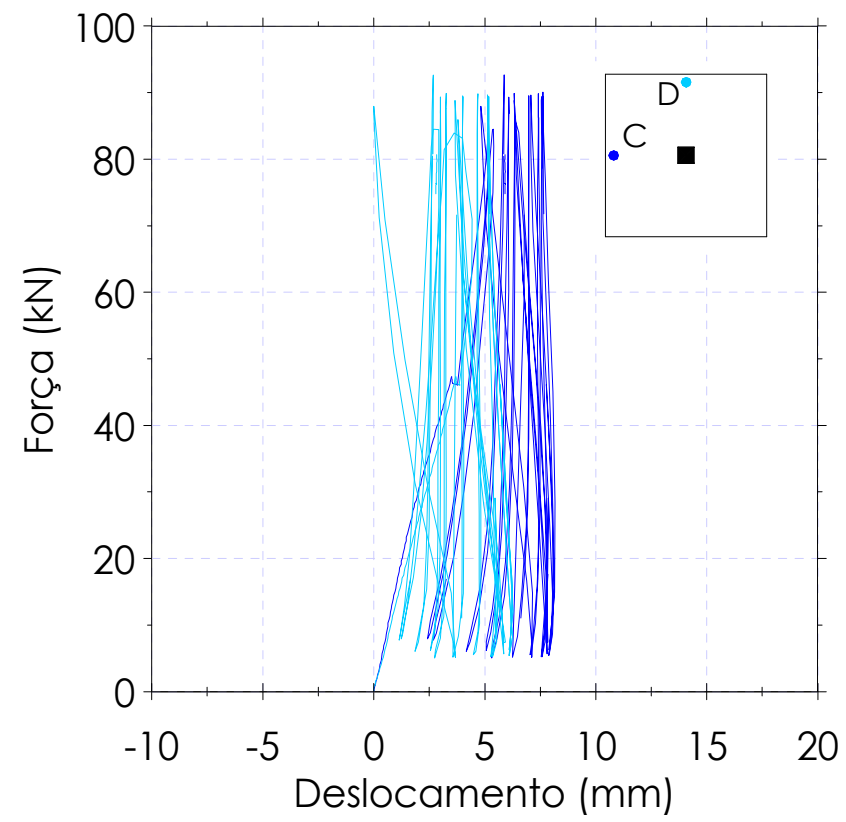

Figura 5.85 - Diagrama força - deslocamentos nas bordas da placa PCA6 


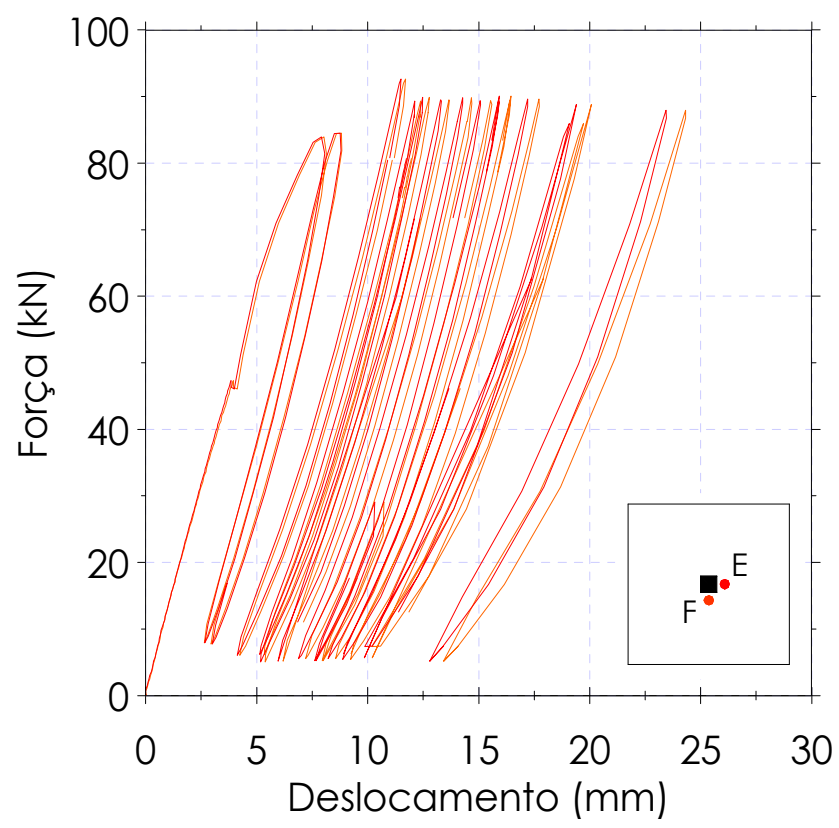

Figura 5.86 - Diagrama força - deslocamentos próximos ao centro da placa PCA6

Na figura 5.86 observa-se o aumento dos deslocamentos e a perda de rigidez sofrida pelo modelo no decorrer do carregamento.

O modelo PCA6 comportou-se bem como placa uniformemente apoiada com força no centro, como se pode ver nas deformações da armadura mostradas nas figuras 5.87 a 5.90 .

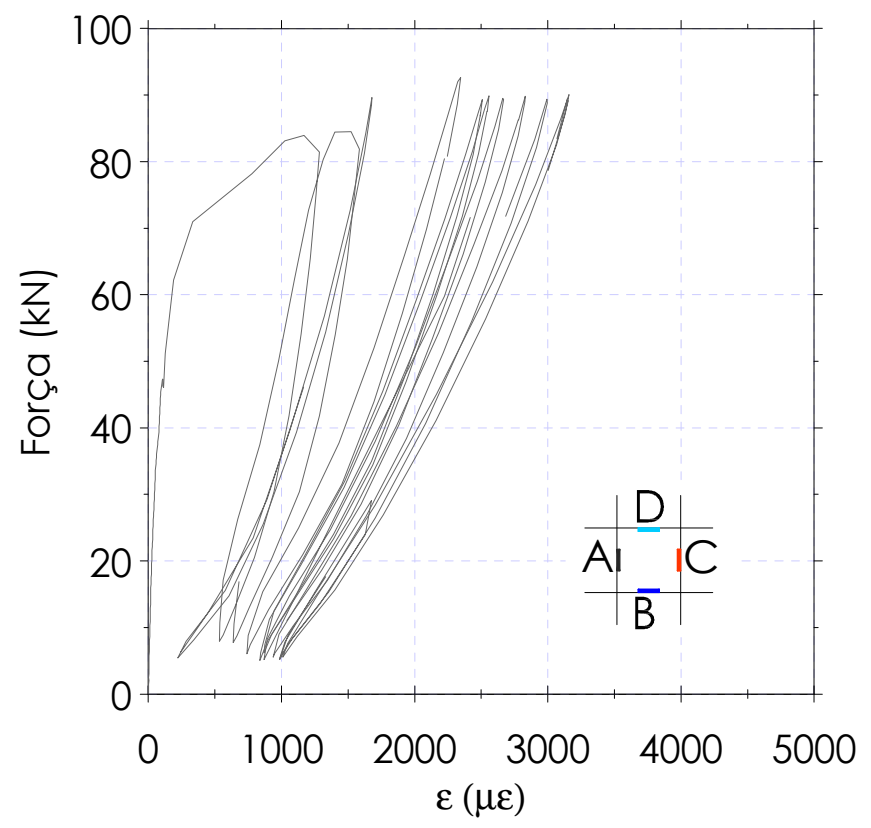

Figura 5.87 - Diagrama força - deformação na armadura, extensômetros A do modelo PCA6 


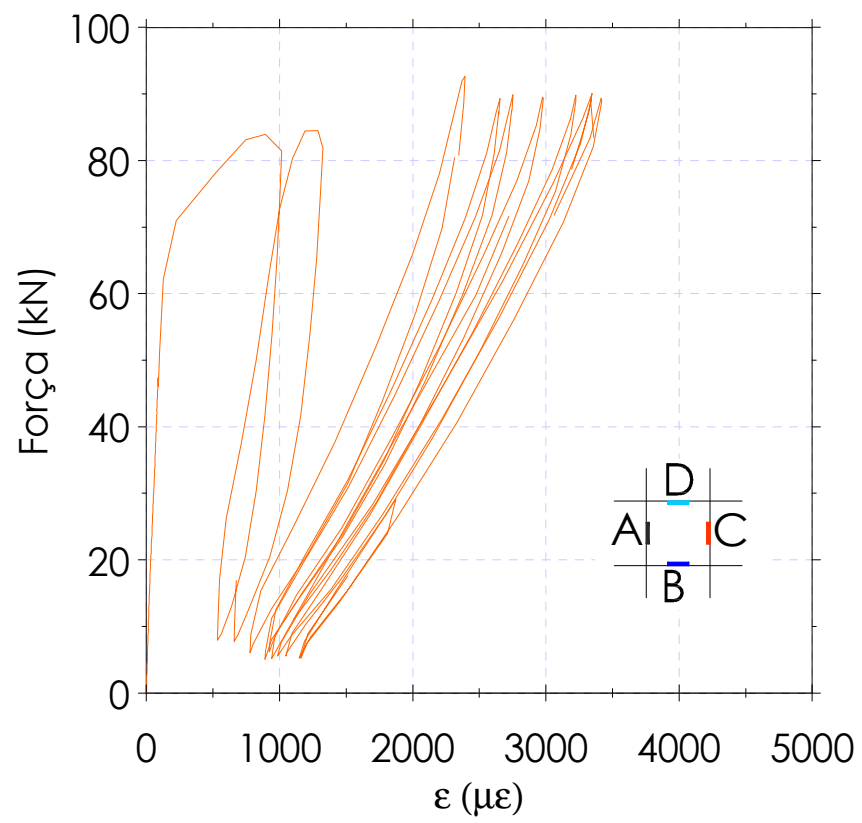

Figura 5.88 - Diagrama força-deformação na armadura, extensômetros C do modelo PCA6

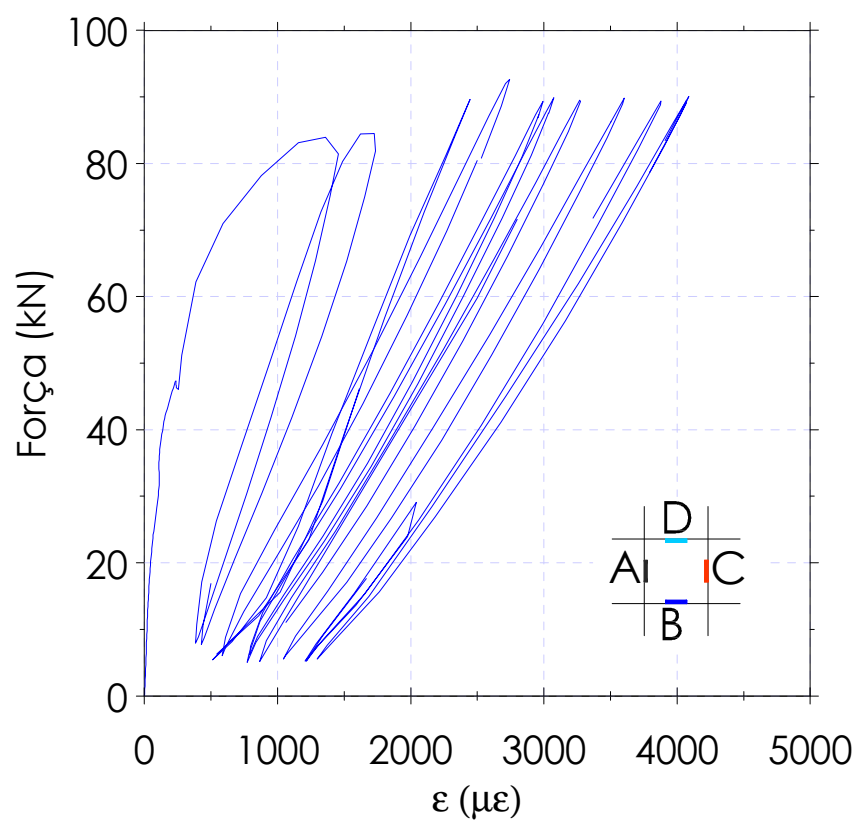

Figura 5.89 - Diagrama força - deformação na armadura, extensômetros B do modelo PCA6 


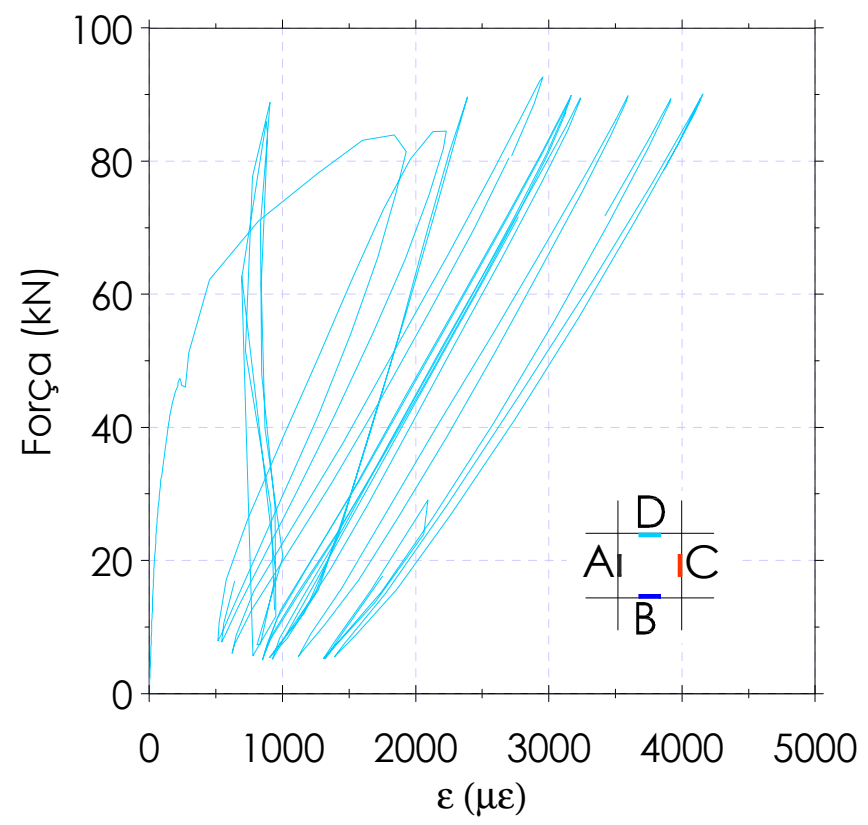

Figura 5.90 - Diagrama força - deformação na armadura, extensômetros D do modelo PCA6

\subsection{CONSIDERAÇÕES SOBRE A ANÁLISE EXPERIMENTAL}

Com os ensaios das vigas da primeira etapa pôde-se verificar o processo de fadiga nas telas soldadas.

Os ensaios da segunda etapa fornecem curvas de força - deslocamento e força deformação que podem ser utilizados na determinação de parâmetros do concreto a serem adotados nas análises numéricas. A partir desses resultados é possivel estabelecer um modelo para estudo das placas da terceira etapa.

Dos ensaios estáticos das placas da terceira etapa obtiveram-se curvas força deslocamento e força - deformação que permitem a comparação e a validação do modelo numérico que será apresentado no capítulo 6.

Para a taxa de armadura adotada, observou-se que o acréscimo da capacidade resistente em relação à placa de concreto simples foi de $60 \%$, ganho semelhante ao observado na faixa.

A repetição do carregamento provoca um dano gradual, observado nos ensaios de fadiga nas placas de concreto armado. O aumento da fissuração, da abertura das fissuras e da deformação do aço provocou a ruína das placas, mesmo estando submetidas a forças inferiores àquela determinada nos ensaios estáticos. 
Conclui-se, portanto, que, assim como os pavimentos de concreto simples, os pavimentos de concreto armado também devem ser dimensionados considerando o efeito da fadiga. 



\section{MODELAGEM NUMÉRICA}

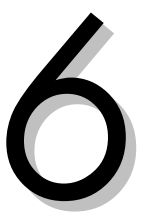

Para que um modelo numérico poça ser utilizado na representação de determinado problema físico, é preciso conhecer as considerações e as simplificações adotadas pelo programa e as limitações da modelagem. Neste capítulo é apresentada a metodologia adotada no desenvolvimento de um modelo que representa o comportamento de placas de concreto armado apoiadas sobre meio elástico. A validação do modelo é feita pela comparação com resultados experimentais, obtidos dos ensaios descritos no capítulo 5.

Para construção da malha de elementos finitos, foi utilizado o programa de préprocessamento True Grid, versão 2.2. Para o processamento foi adotado o Abaqus, versão 6.2, programa baseado no método dos elementos finitos, que possui modelo de concreto, no qual é possível levar em conta a fissuração, o comportamento pós-fissuração, o comportamento plástico na compressão e a presença de armadura. Também pode ser estabelecido um modelo de contato entre as superfícies da placa e da fundação, permitindo o descolamento entre as duas.

\section{1 CRITÉRIOS GERAIS DA MODELAGEM}

Para desenvolvimento do modelo, foram estudados os materiais e os elementos disponíveis no programa, a fim de escolher os que mais se adaptam ao problema em questão. Também foram avaliadas as possibilidades para modelagem do solo e de sua interface com o pavimento. 


\subsubsection{MATERIAIS}

\section{a. Concreto}

O modelo de concreto do Abaqus foi projetado para casos em que o material é sujeito a carregamento monotônico. Desta forma, não é possível fazer uma análise direta da fadiga do material. O modelo considera apenas baixas tensões de confinamento. Entende-se por baixas tensões de confinamento aquelas inferiores a cinco vezes a magnitude da maior tensão que pode ser suportada pelo concreto na compressão uniaxial.

A fissuração é considerada como o aspecto mais importante do comportamento do concreto e, portanto, em conjunto com o comportamento após a fissuração, domina a modelagem. A fissura ocorre quando a tensão atinge uma superfície de formação de fissura, determinada por uma relação linear entre a tensão hidrostática equivalente e a tensão deviatória de Mises. Quando uma fissura é detectada, sua orientação é armazenada para cálculos futuros. As próximas fissuras no mesmo ponto podem ocorrer apenas em direções ortogonais. Neste caso, numa análise tridimensional, podem ocorrer no máximo três fissuras em cada ponto. Essas fissuras são irreversíveis, mas podem abrir e fechar. A presença das fissuras entra nos cálculos, na medida que afetam as tensões e a rigidez associada aos pontos de integração.

O comportamento pós-fissuração é modelado pelo parâmetro "tension stiffening". Desta maneira, é possível incluir os efeitos da interação da armadura com o concreto, de uma maneira simples. Este comportamento é representado por uma curva tensão em função da deformação através da fissura, e está indicado na figura 6.1.

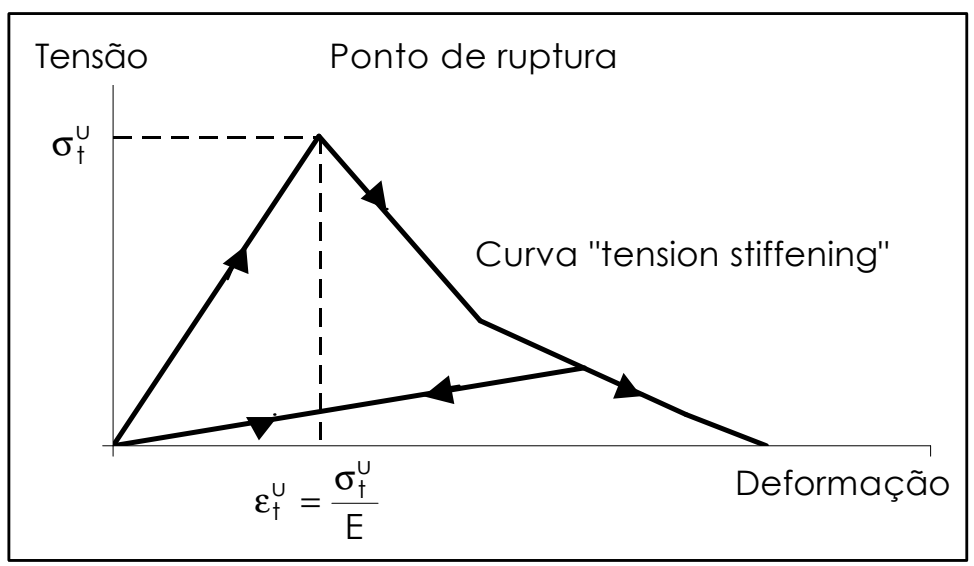

Figura 6.1 - Gráfico "tension stiffening" 
O diagrama tensão - deformação, após a fissuração, deve ser estimado e depende de fatores como: densidade de armadura; condição de aderência entre a armadura e o concreto; diâmetro relativo do agregado comparado com o diâmetro da armadura; e refinamento da malha. Inicialmente pode-se assumir, para uma peça com grande área de aço, modelada com uma malha nem muito pobre nem muito refinada, que o comportamento após a fissuração reduz a tensão linearmente até zero com uma deformação total de aproximadamente dez vezes a deformação no instante da fissuração. Um valor típico de deformação, no instante da fissuração, é de 10-4. Neste caso a deformação total, quando a tensão voltasse a zero, seria adotada igual a 10-3. Este parâmetro deve ser calibrado para casos particulares. Numericamente é mais fácil obter soluções quando a deformação final é maior. Quedas muito bruscas da tensão provocam instabilidades na resposta do modelo.

Quando as componentes principais da tensão são dominantemente de compressão, a resposta do concreto é modelada pela teoria elastoplástica, utilizando uma superfície de escoamento. Como dados da modelagem, são fornecidos, além das características elásticas do material, pontos da curva tensãodeformação na compressão uniaxial, fora do trecho linear. Quando a análise não é uniaxial, é definida uma superfície de ruptura, em que a relação entre a tensão de ruptura uniaxial e a tensão de ruptura biaxial é fornecida ao programa.

Conforme o concreto fissura, sua rigidez ao cisalhamento diminui. Este efeito pode ser simulado, especificando a redução do módulo de cisalhamento como uma função da deformação através da fissura. A redução do módulo de cisalhamento também afeta a tensão normal, quando essa passa a ser de compressão. Esse efeito pode ser negligenciado na análise, nos casos em que a redução da rigidez ao cisalhamento tem pouca influência nos resultados que se deseja obter. Os ensaios necessários para determinar o comportamento ao cisalhamento após a fissuração são consideravelmente difíceis. No caso de não se dispor desses resultados, um ponto de partida seria assumir que o fator de resistência ao cisalhamento decresce linearmente até zero, na mesma abertura de fissura usada para o modelo de pós-fissuração à tração. 


\section{b. Armadura}

O Abaqus possibilita a introdução de barras posicionadas no elemento de concreto. Essas barras são elementos unidirecionais, que podem ser definidos um a um ou embutidos em superfícies orientadas. Para as barras de aço, pode-se utilizar material elastoplástico.

Nas aproximações do modelo, o comportamento do concreto é considerado independente do das barras de aço. Os efeitos associados à interface dos dois materiais devem ser simulados pelo comportamento pós-fissuração.

\subsubsection{ELEMENTOS}

Para modelar os pavimentos de concreto, são necessários elementos tridimensionais, que podem ser sólidos ou placas. O Abaqus possui elementos que podem ser compostos de um único material ou incluir diversas camadas diferentes. No caso da modelagem de pavimentos, elementos com diversas camadas podem ser utilizados na definição do volume de solo. Os elementos sólidos ou de placas, utilizados na análise de tensão e deformação, podem ser usados em análises lineares ou não-lineares, incluindo plasticidade, contato e grandes deformações.

A biblioteca de elementos do Abaqus inclui elementos de interpolação linear (primeira ordem) e de interpolação quadrática (segunda ordem). Os elementos de segunda ordem são mais precisos em problemas que não envolvem condições de contato, impacto ou distorções severas. Eles consideram as concentrações de tensão e são melhores na modelagem de geometrias mais complexas. Esse tipo de elemento é mais efetivo em problemas de flexão. Porém, no caso dos pavimentos em que é introduzido contato entre a placa e o solo, é mais aconselhável utilizar elementos de interpolação linear. Deve-se evitar o uso de elementos lineares triangulares ou tetraédricos, pois seria necessária uma malha muito refinada. Neste caso é mais aconselhável a utilização de elementos hexaédricos.

Os elementos podem ser ainda de integração completa ou reduzida. A integração reduzida diminui o tempo de processamento, especialmente em elementos tridimensionais. Para elementos de segunda ordem, a integração reduzida geralmente produz melhores resultados. Porém, para elementos lineares, 
a relação entre os resultados dos dois tipos de integração depende da natureza do problema. Os elementos lineares com integração reduzida produzem descontinuidades e distorções. Portanto, devem ser usados com malha mais refinada.

Os elementos com integração completa podem apresentar um comportamento de travamento, "locking", que pode ser de cisalhamento ou volumétrico. O efeito conhecido como "shear locking" ocorre em elementos de primeira ordem com integração completa, sujeitos à flexão. A formulação do elemento provoca um aumento nas tensões de cisalhamento, que na verdade não existe. Desta forma, esses elementos ficam muito rígidos na flexão, em particular se o tamanho do elemento for da mesma ordem da espessura do modelo. O efeito de "volumetric locking" ocorre em elementos com integração reduzida, quando o comportamento do material é incompressível ou quase incompressível. No caso de material elástico linear, por exemplo, o material pode ser considerado quase incompressível, quando o coeficiente de Poisson for maior que 0,48.

O problema das placas apoiadas sobre solo envolve contato, portanto devem ser adotados elementos de primeira ordem. A escolha de integração reduzida ou completa deve ser avaliada, comparando os resultados de ambas com os dados experimentais.

Os pavimentos podem ser modelados com elementos de placas apoiadas sobre elementos volumétricos. Desta forma o solo é considerado um sólido elástico, e suas constantes são o módulo de elasticidade e o coeficiente de Poisson. Outra maneira de simular o solo é acoplar molas aos nós da placa. Assim, o solo é considerado um líquido denso, e o parâmetro a ser fornecido é a constante das molas. Se as molas forem acopladas aos nós da placa do pavimento, elas impedem que haja um descolamento deste com o solo, produzindo resultados distorcidos. Uma forma de modelar o solo por meio de molas, e permitir o descolamento entre pavimento, e fundação, é introduzir outra placa, de pequena espessura e baixo módulo de elasticidade, tangente à face inferior da placa de concreto, e nesta sim, acoplar as molas que representam o solo. O modelo de contato seria estabelecido entre essas duas placas. 


\subsubsection{CONTATO}

O contato entre dois corpos deformáveis pode ser modelado usando contato com base em superfícies. Para definição do contato, é preciso determinar as faces dos elementos que potencialmente podem estar em contato, especificar quais superfícies interagem, e definir as características mecânicas que governam o comportamento das superfícies. Pode-se escolher o tipo de contato, permitindo ou não o descolamento entre as superfícies.

A ordem em que as superfícies são definidas no par de contato é fundamental. Para cada nó da primeira superfície, chamada de "slave", o programa busca o ponto mais próximo na segunda superfície, "master". A normal da segunda superfície passa através dos nós da primeira. Superfícies "slave" sempre devem ser associadas a corpos deformáveis. Superfícies rígidas devem sempre ser "master". Não pode haver contato entre duas superfícies rígidas.

Quando as duas superfícies do par de contato forem deformáveis, o usuário deve escolher qual superfície será "slave" e qual será "master". Geralmente, para superfície "master" é escolhida a de malha mais pobre, quando as estruturas têm rigidezes semelhantes. A rigidez a ser considerada é a rigidez da estrutura, e não apenas a do material.

No caso dos pavimentos com o solo modelado como sólido elástico, apesar do solo possuir módulo de elasticidade menor que o concreto, a massa de solo, que tem dimensões muito superiores, é mais rígida e deve ter a superfície "master".

Se a opção for modelar o solo como líquido denso e estabelecer o contato entre duas placas, a superfície "slave" deve ser a placa de fundação.

\subsection{MODELO DE VIGA DE CONCRETO ARMADO}

A fim de verificar o modelo de concreto armado do programa, e determinar valores para o diagrama tensão-deformação após a fissuração, foram modeladas vigas simplesmente apoiadas e comparados seus resultados com os ensaios da segunda etapa, mostrados no capítulo 5. Para tanto foram utilizados elementos de placa - S4R -, com barras de aço posicionadas no concreto - "rebar". A geometria das vigas é igual às da segunda etapa da análise experimental. 
Nos gráficos das figuras 6.2, 6.3, 6.4 e 6.5 são comparados os resultados numéricos e experimentais, para vigas de concreto simples com três áreas de aço, ensaiadas em laboratório. O trecho da curva indicado por numérico-linear representa o início do carregamento, quando o concreto ainda não apresenta fissuração. O trecho identificado por numérico-fissurado corresponde à fase em que já há formação de fissuras. Logo após a fissuração, o modelo apresenta em trecho de instabilidade e depois converge para resultados semelhantes aos obtidos na análise experimental.

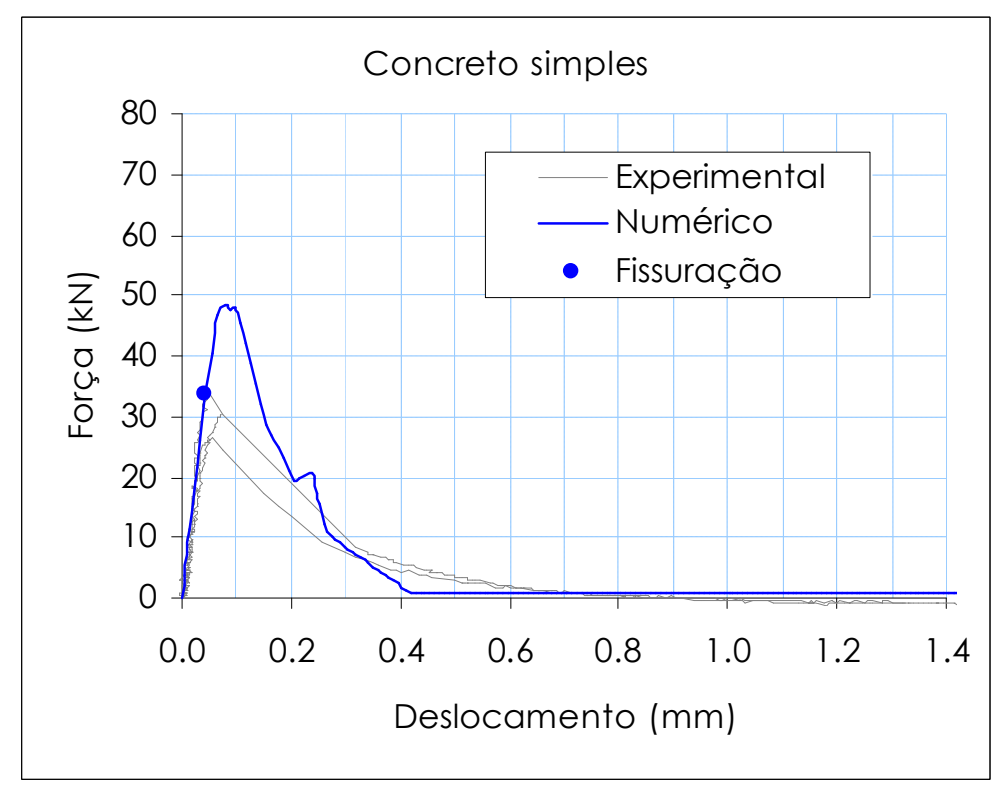

Desprezando o trecho de instabilidade logo após a fissuração do concreto, o modelo numérico apresenta resultados compatíveis com a análise experimental.

Figura 6.2 - Viga de concreto simples resultado numérico $x$ experimental

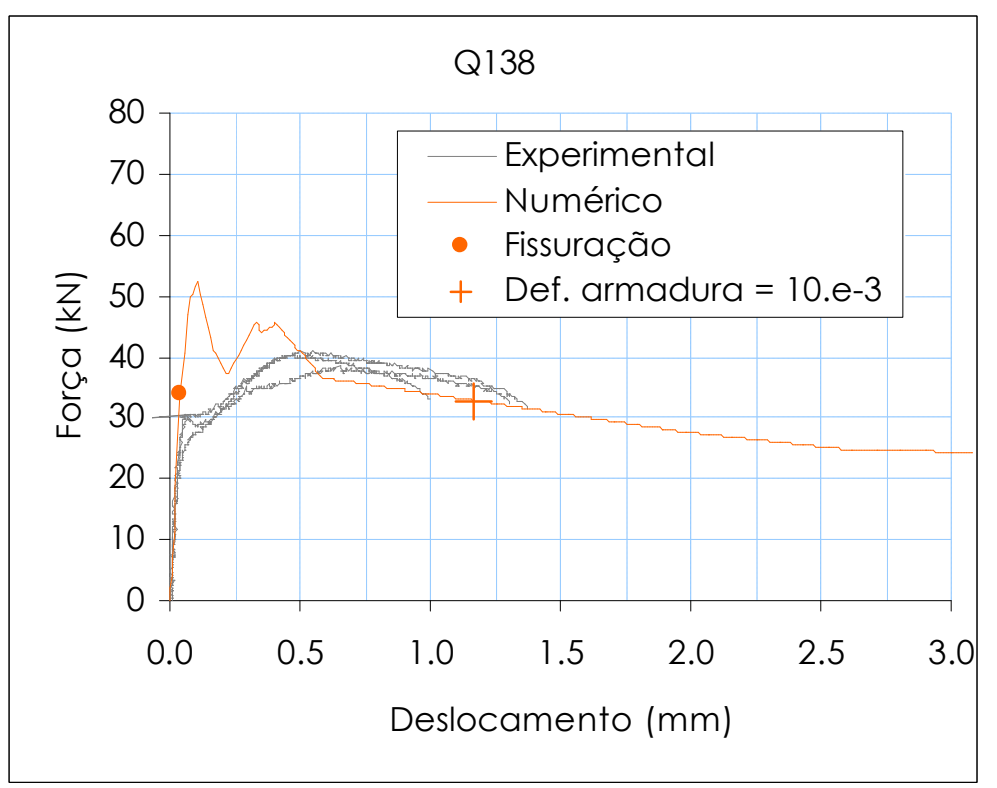

A fim de determinar a ruína do modelo, pode-se estabelecer um critério, como por exemplo a deformação do aço ou do concreto comprimido.

Figura 6.3 - Deslocamentos da viga Q138 resultado numérico $\mathrm{x}$ experimental 


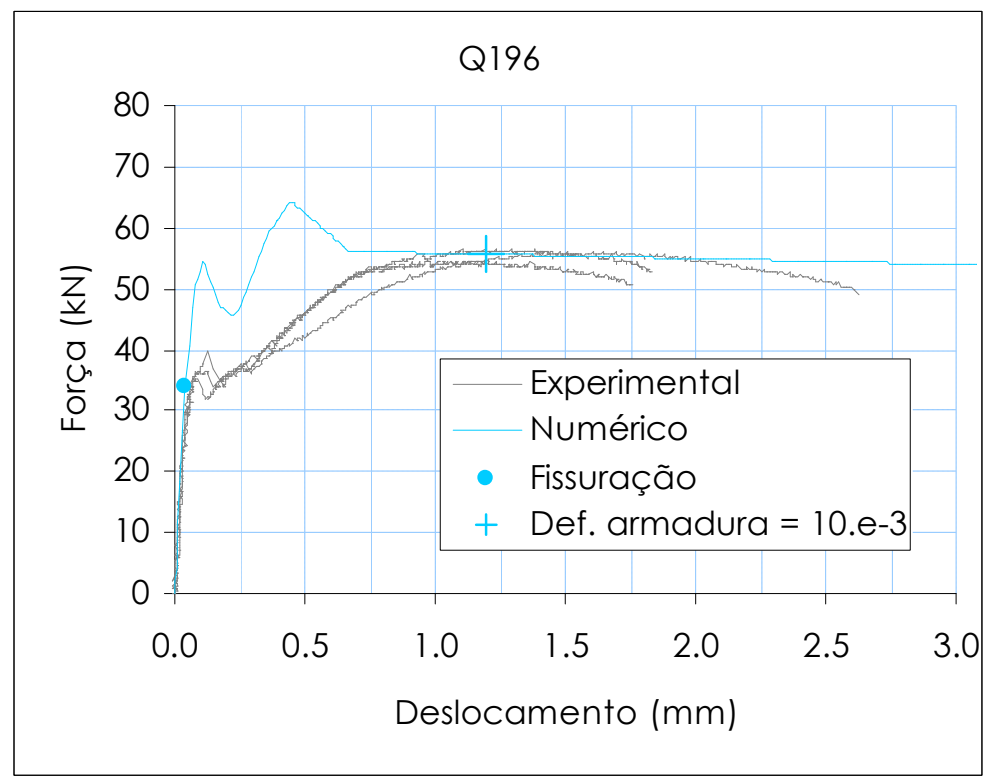

Figura 6.4 - Deslocamentos da viga Q196resultado numérico $x$ experimental

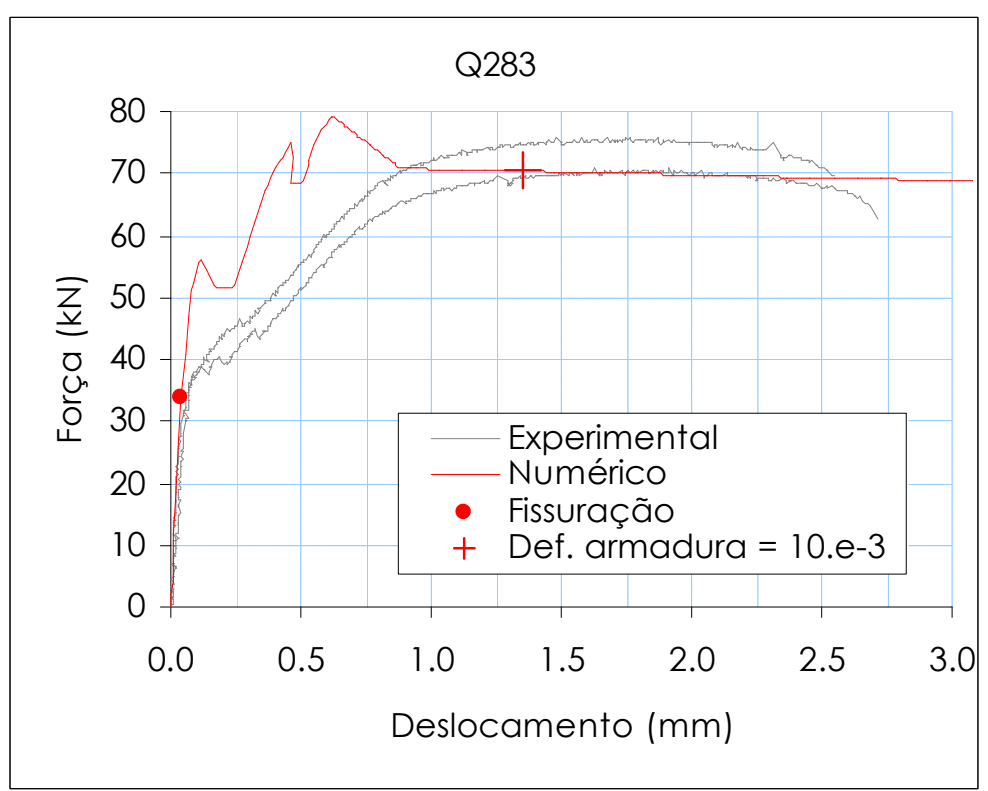

Figura 6.5 - Deslocamentos da viga Q283 resultado numérico $x$ experimental
Assim como nos dois

modelos anteriores, para

a tela Q196, desprezando

o trecho de instabilidade,

o modelo apresentou

resultados semelhantes

aos obtidos nos ensaios

de laboratório.

A fissuração do concreto ocorre praticamente no mesmo ponto para os três modelos. Após a fissuração verifica-se a contribuição da armadura.

A abertura de fissuras nos quatro modelos ocorre praticamente no mesmo ponto, quando a tensão no concreto atinge o critério de fissuração. O comportamento após a fissuração é diferenciado pela presença de armadura, pela área de aço e pelos valores de deformação pós- fissuração, adotados no modelo.

Nas figuras 6.6, 6.7 e 6.8 são mostrados os diagramas força-deformação obtidos do modelo numérico e comparados com os resultados experimentais da segunda etapa. 


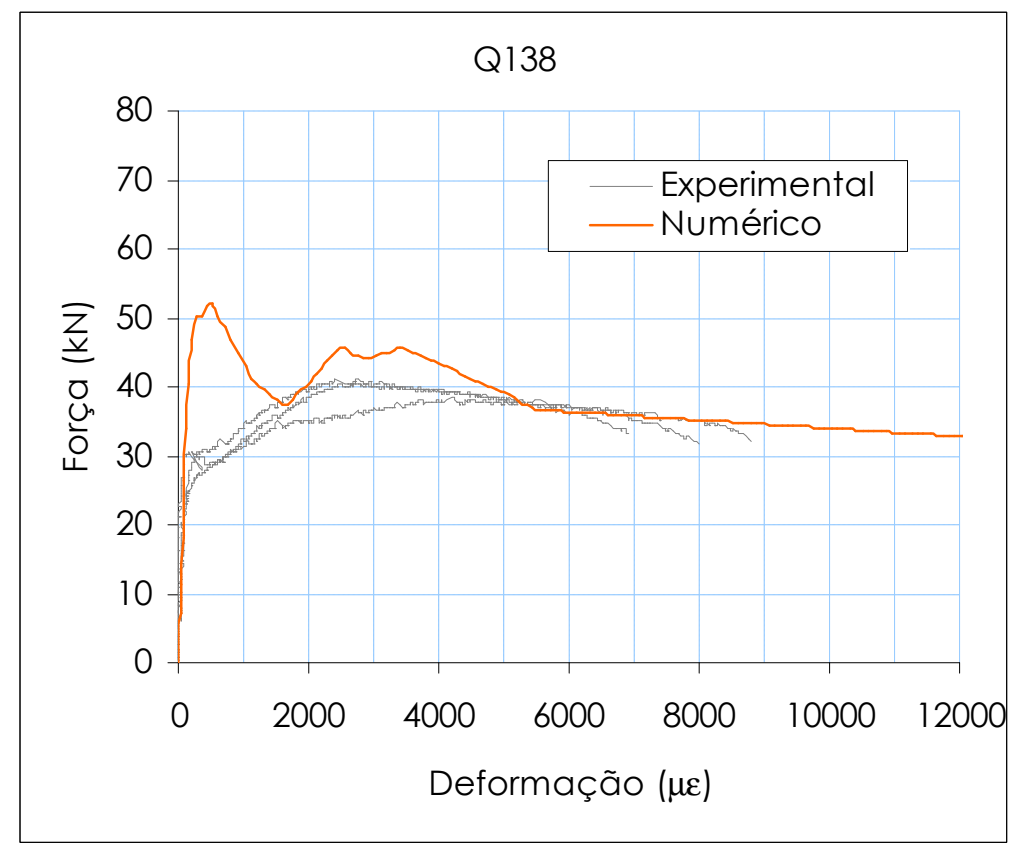

Para as deformações equivalentes na face inferior, no meio da viga, os resultados numéricos também se aproximaram dos experimentais, exceto no trecho de instabilidade.

Figura 6.6 - Deformação da viga Q138 resultado numérico $x$ experimental

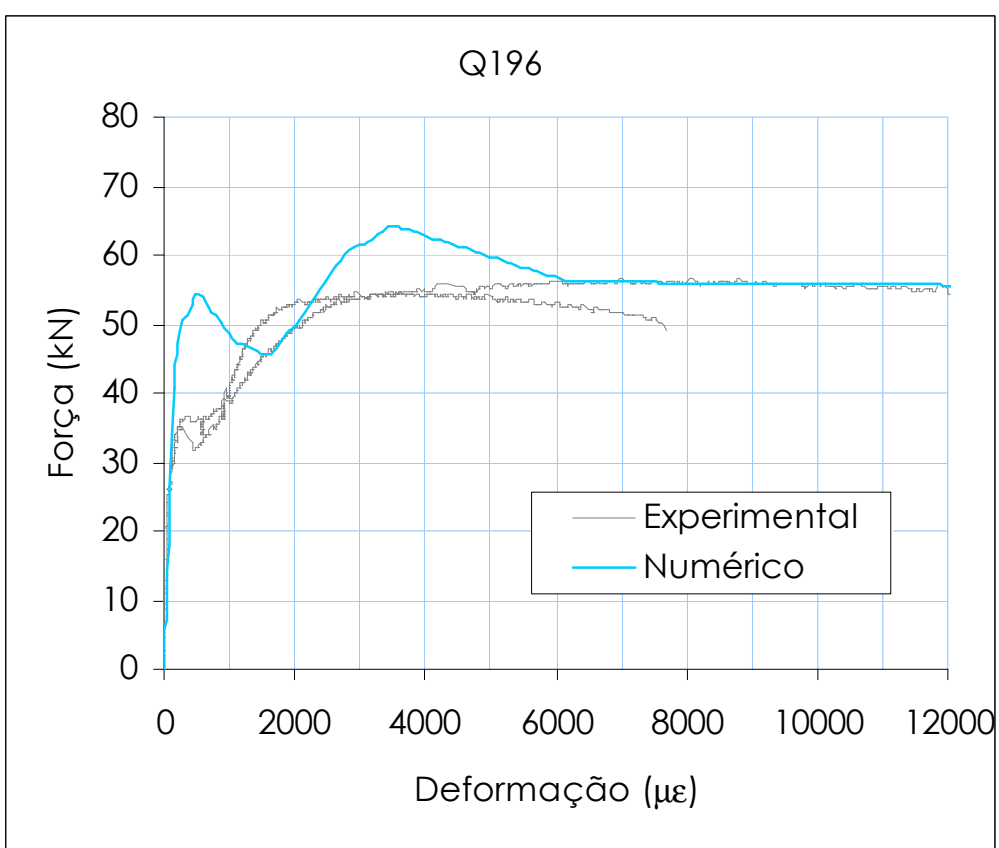

Figura 6.7 - Deformação da viga Q196 resultado numérico $x$ experimental 


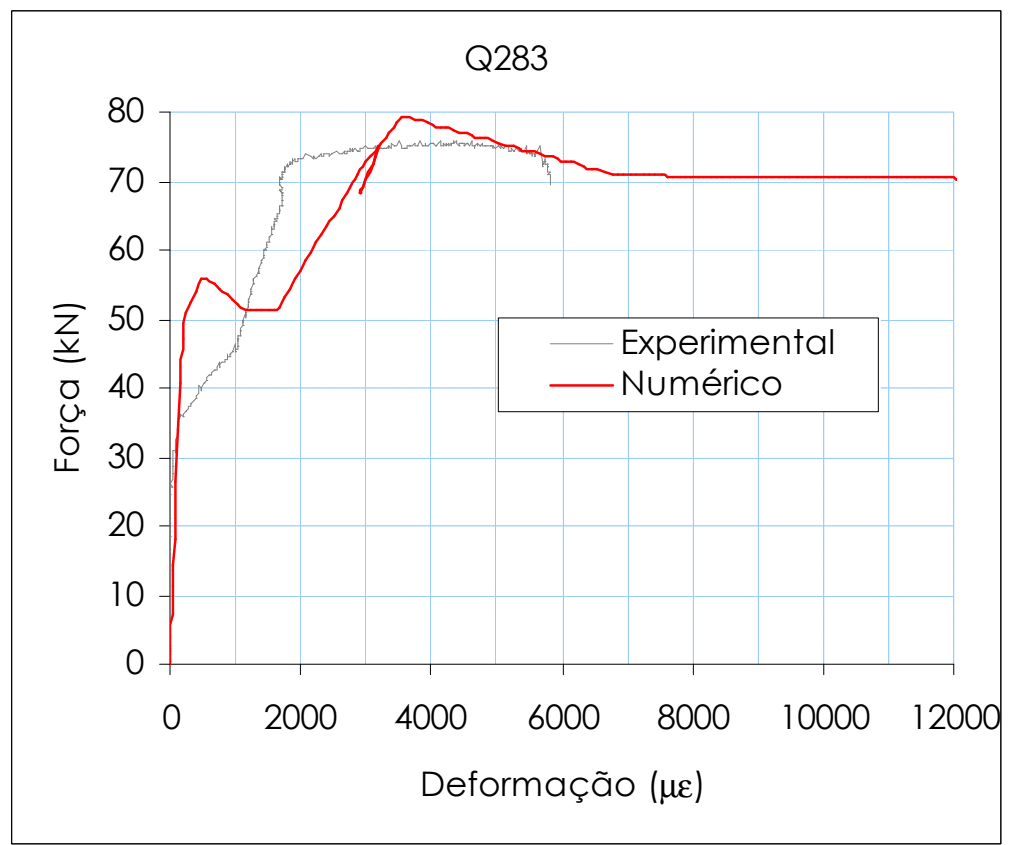

Figura 6.8 - Deformação da viga Q283 resultado numérico $\mathrm{x}$ experimental
No modelo com tela

Q283, a força na qual se observa o patamar do gráfico tensãodeformação coincide com a experimental, mas o trecho de instabilidade prejudica os valores de deformação.

Para o comportamento pós-fissuração do concreto, foram adotados diagramas lineares e bilineares. Os pontos que definem esses diagramas estão apresentados na tabela 6.1.

Tabela 6.1 - Valores tensão e deformação após a fissuração do concreto

\begin{tabular}{ccccccc}
\hline Modelo & $\sigma / \mathrm{f}_{\mathrm{Ct}}{ }^{1}$ & $\varepsilon_{\mathrm{p}}{ }^{1}$ & $\sigma / \mathrm{f}_{\mathrm{Ct}}{ }^{2}$ & $\varepsilon_{\mathrm{p}}{ }^{2}$ & $\sigma / \mathrm{f}_{\mathrm{ct}}{ }^{3}$ & $\varepsilon_{\mathrm{p}}{ }^{3}$ \\
\hline CS & 1 & 0 & 0 & $10 . \mathrm{E}^{-4}$ & - & - \\
Q138 & 1 & 0 & 0,20 & $10 . \mathrm{E}^{-4}$ & 0 & $20 . \mathrm{E}^{-3}$ \\
Q196 & 1 & 0 & 0,30 & $10 . \mathrm{E}^{-4}$ & 0 & $20 . \mathrm{E}^{-2}$ \\
Q283 & 1 & 0 & 0,32 & $10 . \mathrm{E}^{-4}$ & 0 & $20 . \mathrm{E}^{-2}$ \\
\hline
\end{tabular}

Os modelos para o comportamento pós-fissuração do concreto estão representados na figura 6.9.

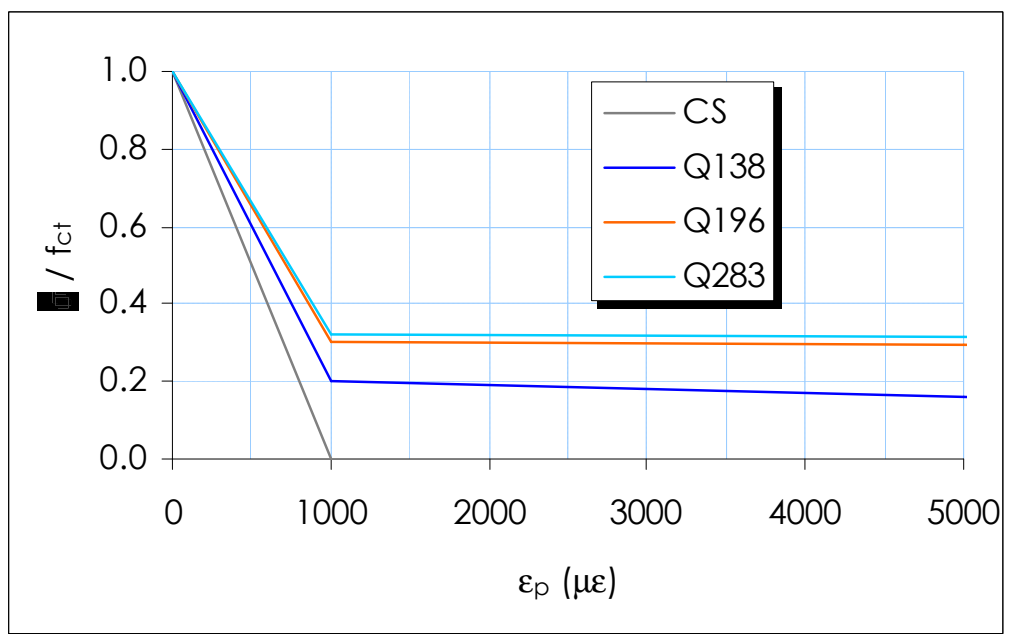

Figura 6.9 - Comportamento pós-fissuração do concreto para concreto simples, e armado com telas Q138, Q196 e Q283 
Os valores da curva tensão-deformação após a fissuração do concreto, indicados na tabela 6.1, que forneceram resultados compatíveis com a análise experimental, serão utilizados no desenvolvimento dos modelos de placas apoiadas sobre meio elástico.

6.3 PlacAs apoladAs SOBRE MEIO ELÁstICO

Para definição do modelo numérico, foi utilizada inicialmente a geometria e as características dos materiais das placas ensaiadas no laboratório. Assim, é possível a comparação entre resultados numéricos e experimentais. Determinado que o pavimento seria modelado com elemento de placa, ainda faltava definir se esse seria de integração completa ou reduzida. Era preciso ainda escolher o modelo para o solo, se sólido elástico ou líquido denso (molas). Nas figuras 6.10 e 6.11 são mostradas as malhas para os dois modelos (sólido elástico e líquido denso).

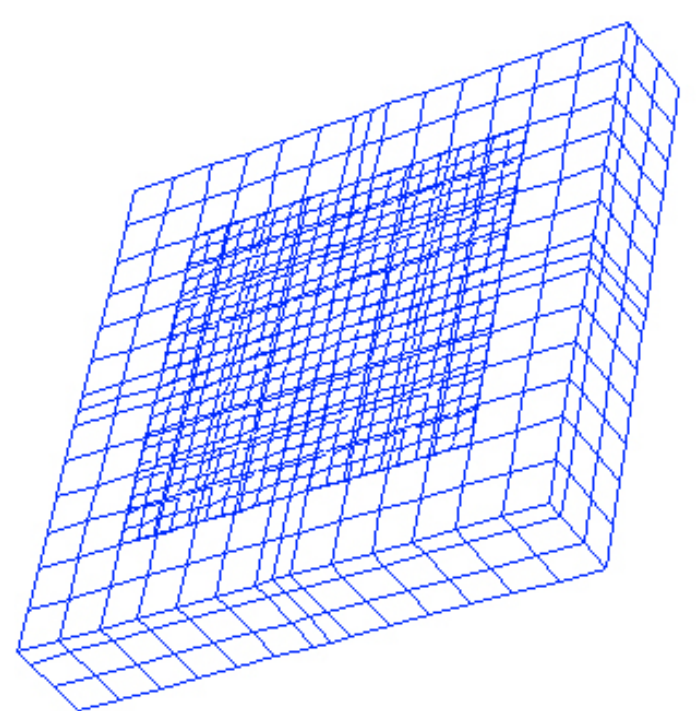

Figura 6.10 - Malha para modelo de placa apoiada sobre sólido elástico

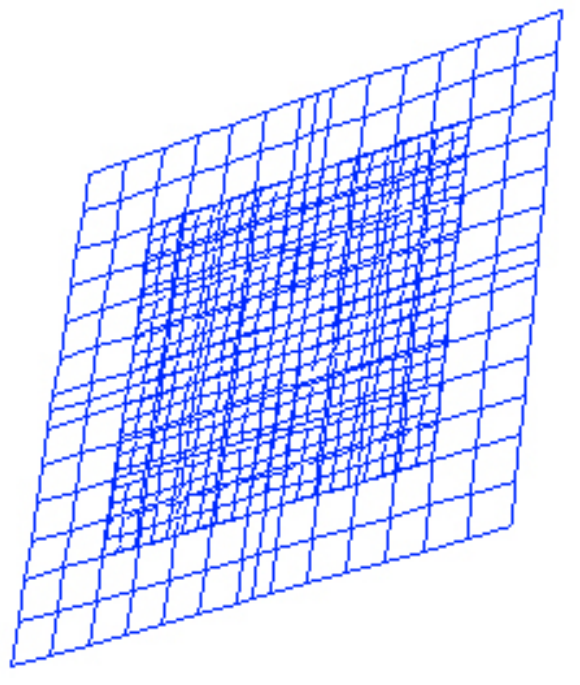

Figura 6.11 - Malha para modelo de placa apoiada placa com molas nos nós

A figura 6.12 mostra a comparação entre os modelos sólido elástico e líquido denso, para a fundação. 


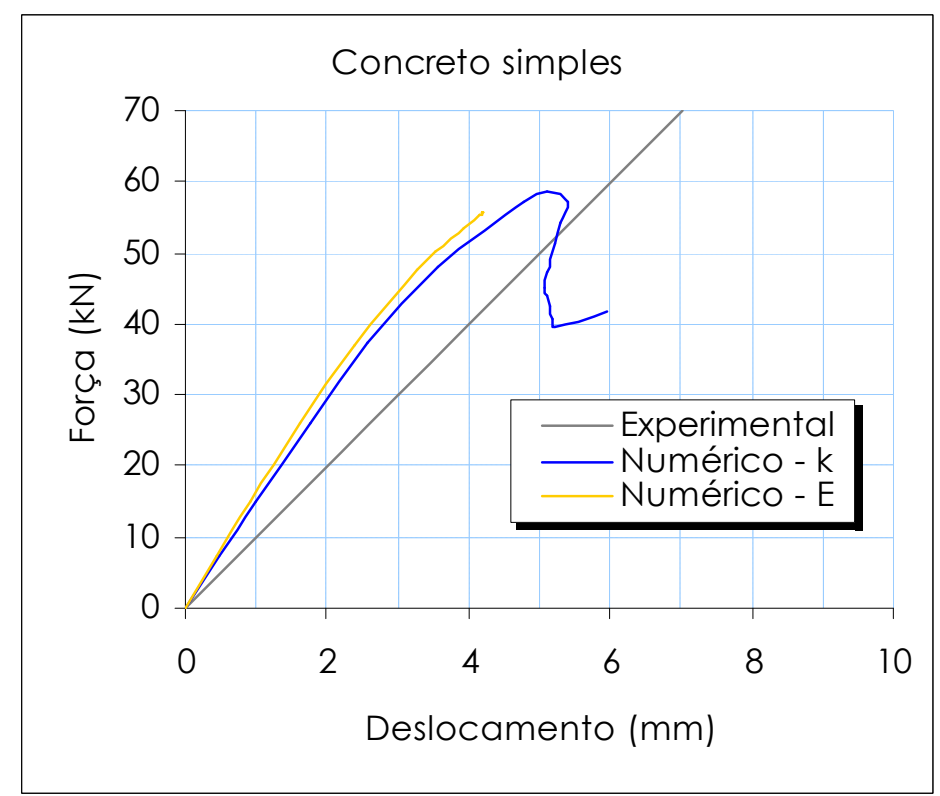

Figura 6.12 - Modelo de sólido elástico x líquido denso

Os resultados para as duas modelagens são semelhantes, sendo que o modelo de líquido denso (k), em que molas são introduzidas nos nós da placa de fundação em contato com a placa do pavimento, apresenta convergência mais fácil que o modelo de sólido elástico (E). Desta forma, para as próximas análises, será utilizado o modelo de líquido denso.

$\mathrm{Na}$ figura 6.13 são apresentados os resultados do modelo de placa com elementos com integração completa e com integração reduzida.

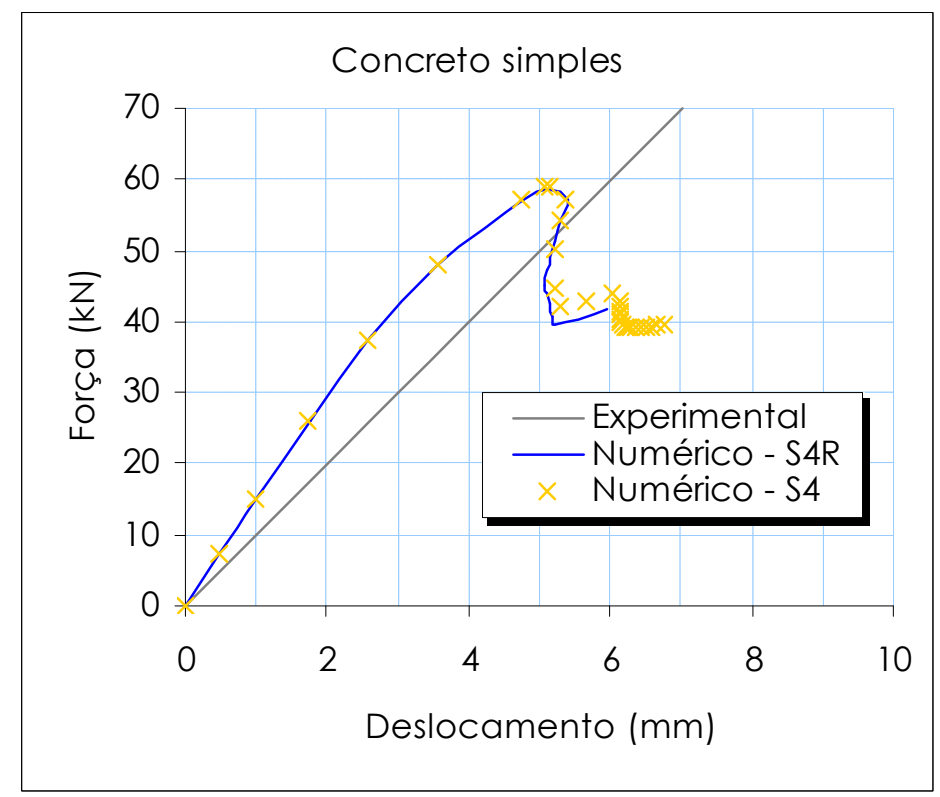

Figura 6.13 - Elemento com integração completa x integração reduzida 
Os elementos com integração completa (S4) e com integração reduzida (S4R) forneceram respostas praticamente iguais. Visto que os de integração reduzida são menos onerosos computacionalmente, serão adotados nas próximas análises.

Dessa forma, o modelo de placa de concreto armado apoiada sobre o solo foi desenvolvido com elementos de placa com integração reduzida. A armadura foi introduzida como duas superfícies orientadas nas direções x e y. A figura 6.14 ilustra o modelo adotado para análise numérica.

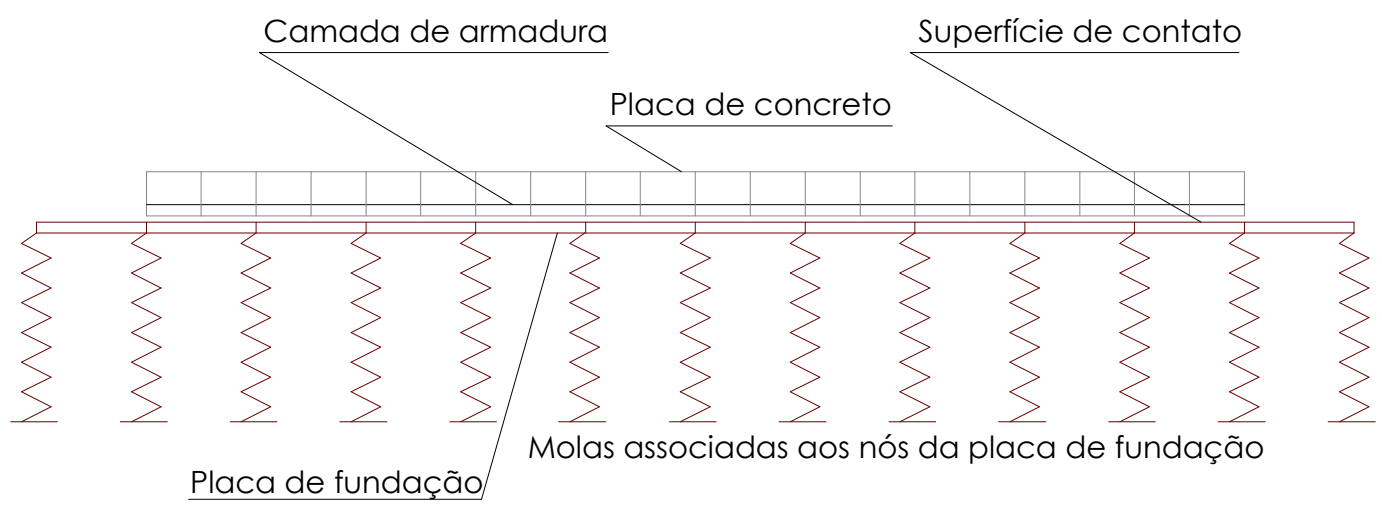

Figura 6.14 - Modelo de placa de concreto armado apoiada sobre o solo

Nos diagramas das figuras 6.15 são traçados os deslocamentos no centro, no canto e na borda da placa, medidos na análise experimental e determinados com a modelagem numérica.

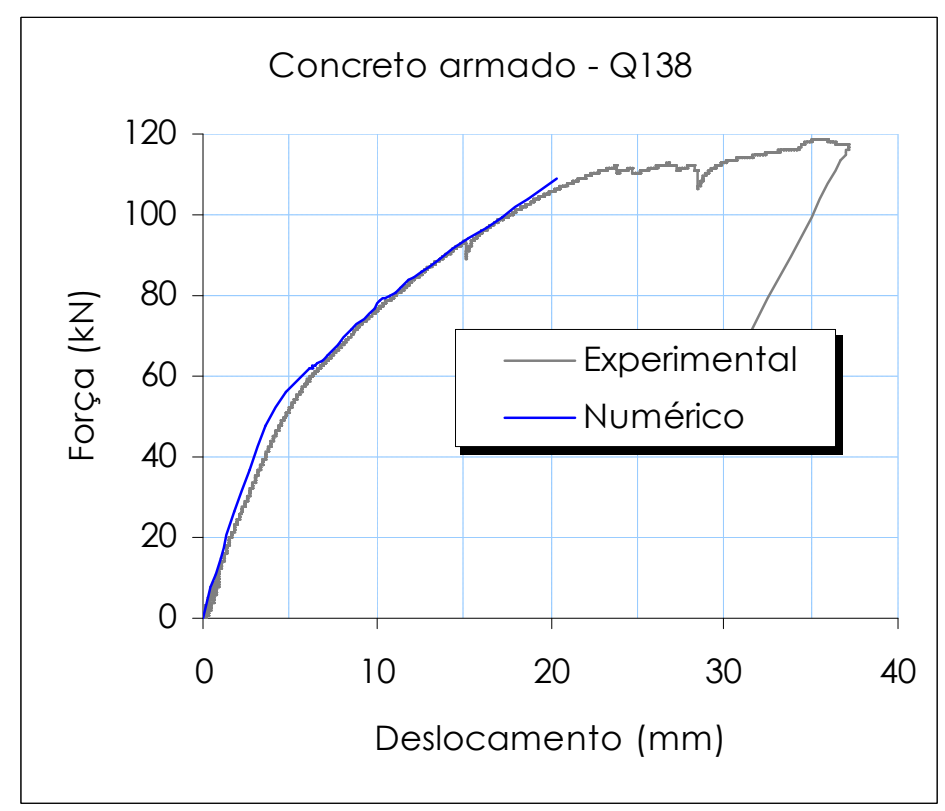

O modelo numérico apresentou convergência até uma força de $108,92 \mathrm{kN}$.

Figura 6.15 - Deslocamentos no centro da placa modelo numérico $x$ experimental 


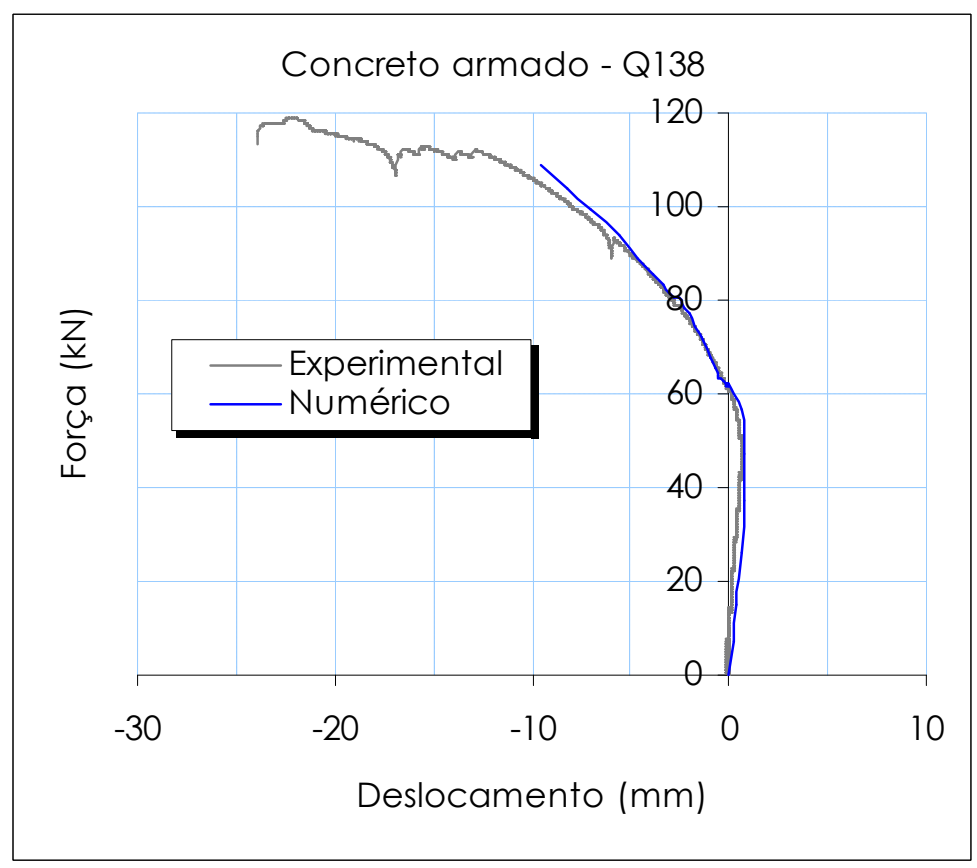

Figura 6.16-Deslocamentos no canto da placa modelo numérico $x$ experimental

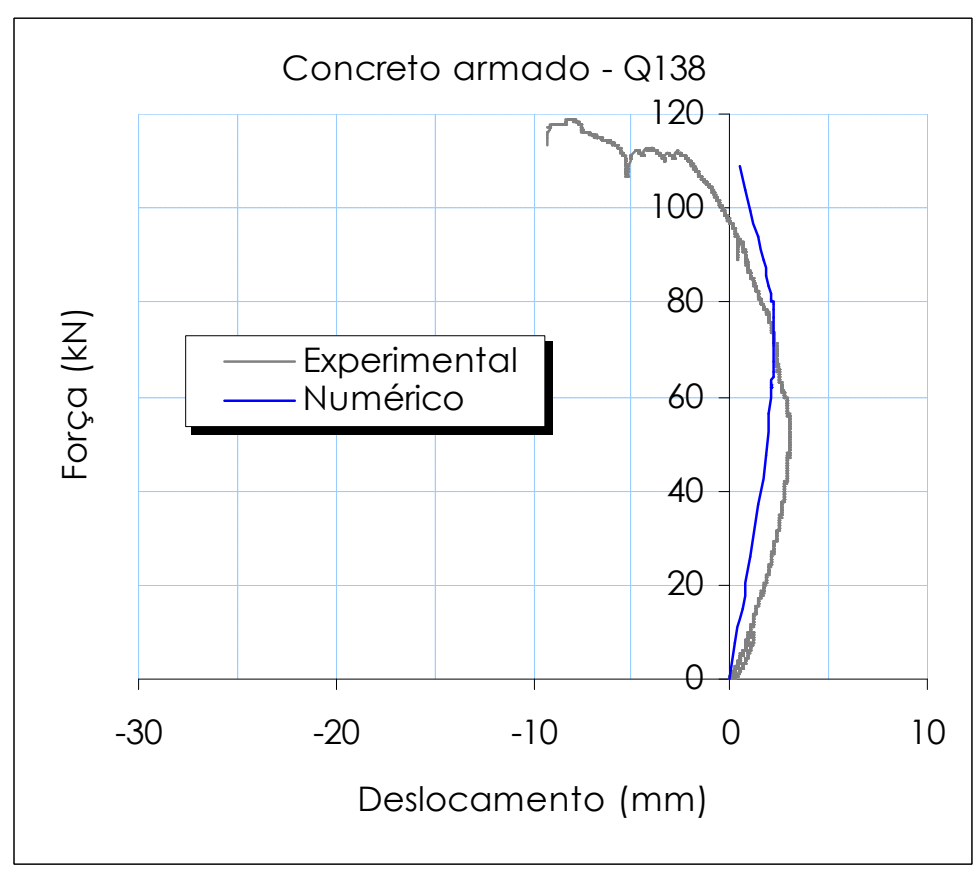

Figura 6.17 - Deslocamentos na borda da placa modelo numérico $x$ experimental
Assim como no centro da placa, os deslocamentos no canto, determinados pelo modelo numérico, são bastante semelhantes aos deslocamentos medidos no ensaio físico.

Também na borda da placa, verificou-se a semelhança entre modelos numérico e experimental.

A figura 6.18 mostra um diagrama dos deslocamentos nas placas, quando é aplicada a força de 108,92 kN. Verifica-se a separação entre a borda da placa e o solo. 


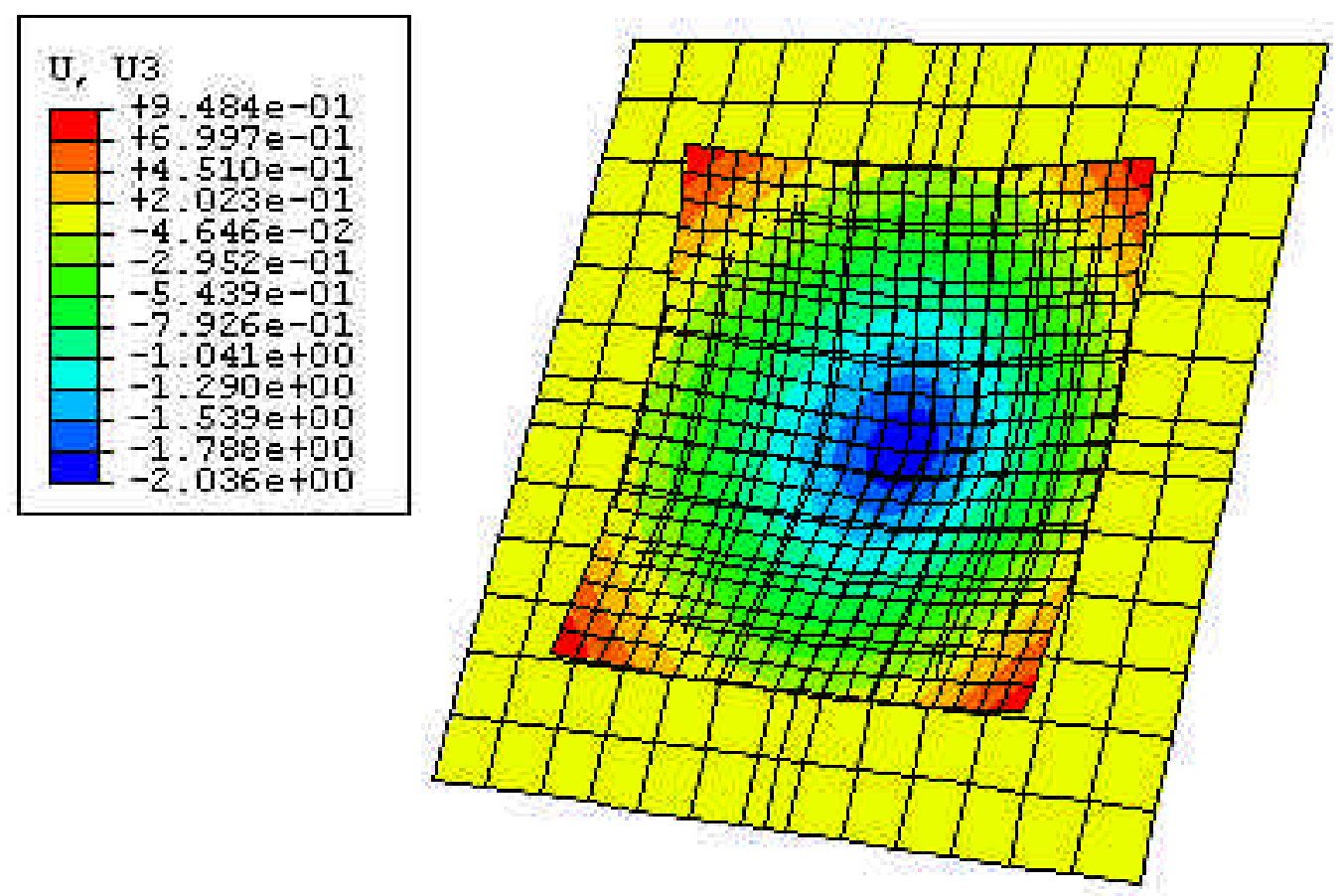

Figura 6.18 - Deslocamentos, em cm, na placa de concreto armado, com força de 108,92 kN aplicada no centro

As aberturas entre a placa e o solo são mostradas na figura 6.19.
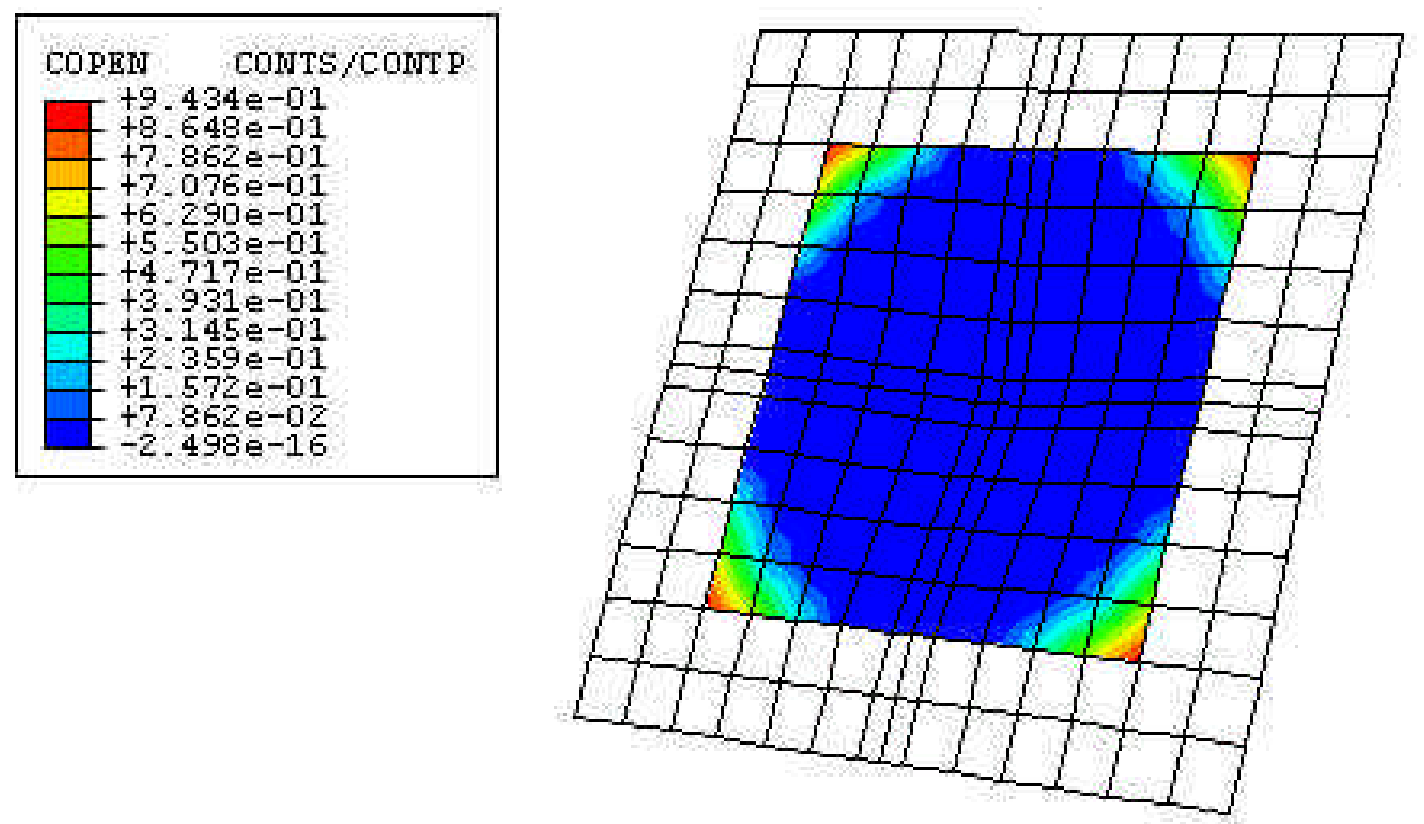

Figura 6.19 - Aberturas, em cm, entre a placa de concreto e o solo, com força de 108,92 kN aplicada no centro

A pressão que a placa de concreto exerce sobre a placa da fundação está plotada na figura 6.20 . 

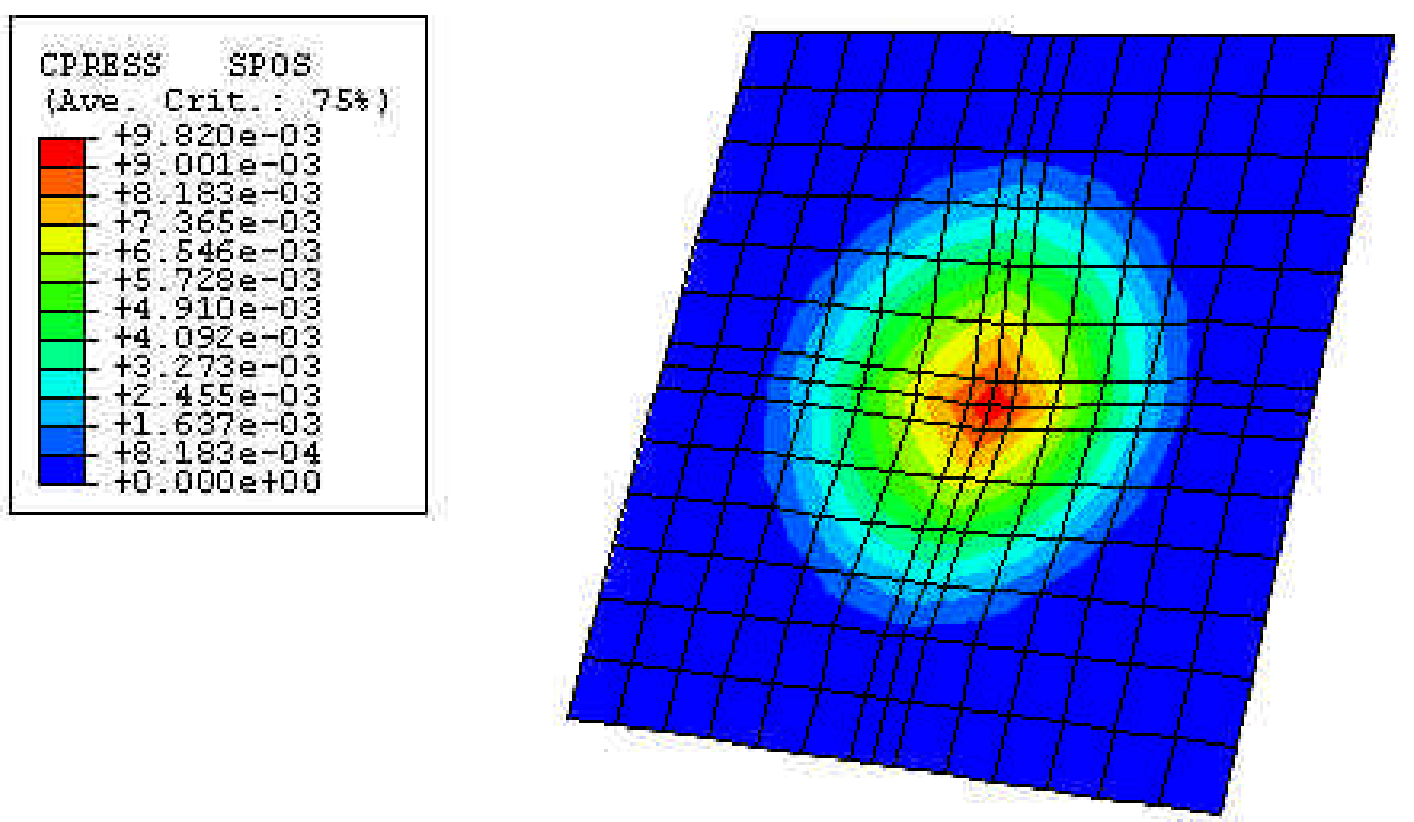

Figura 6.20 - Pressão, em kN/cm², que a placa de concreto aplica na placa de fundação, com força de 108,92 kN aplicada no centro

Nas figuras 6.21 a 6.27 são mostradas as tensões principais na face inferior da placa, no decorrer do carregamento, e na figura 6.28 são mostradas as tensões principais de compressão na face superior da placa, quando é aplicada a força de $108,92 \mathrm{kN}$.
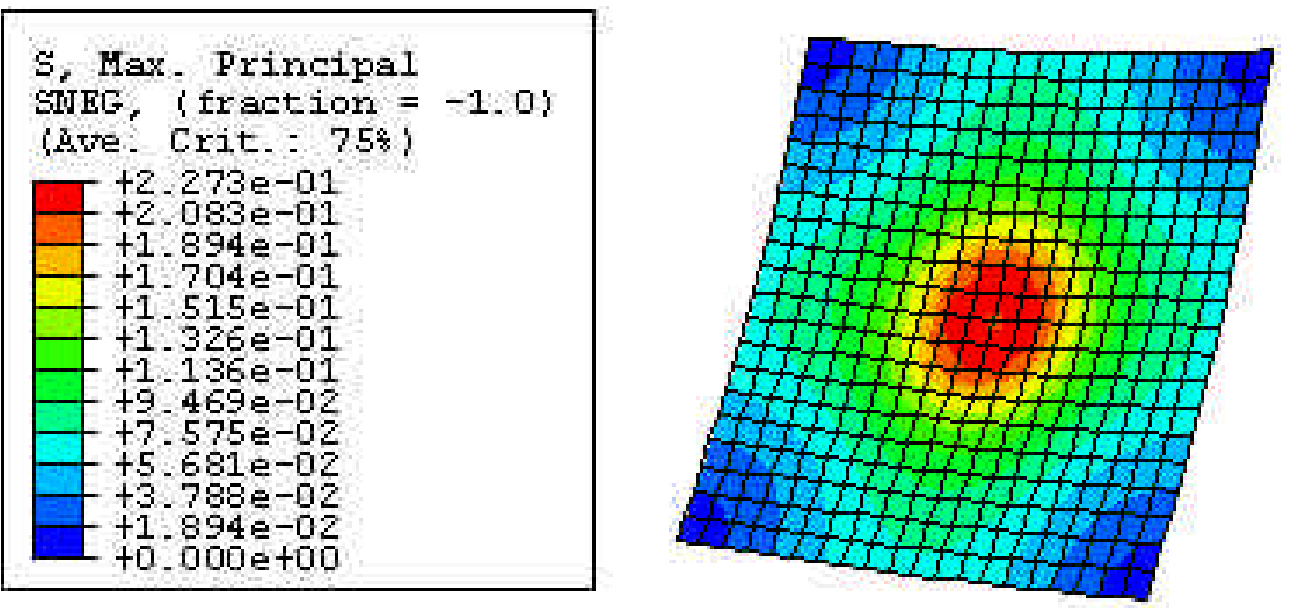

Figura 6.21 - Tensões principais, em $\mathrm{kN} / \mathrm{cm}^{2}$, na face inferior da placa de concreto armado, com força de $15 \mathrm{kN}$ aplicada no centro 

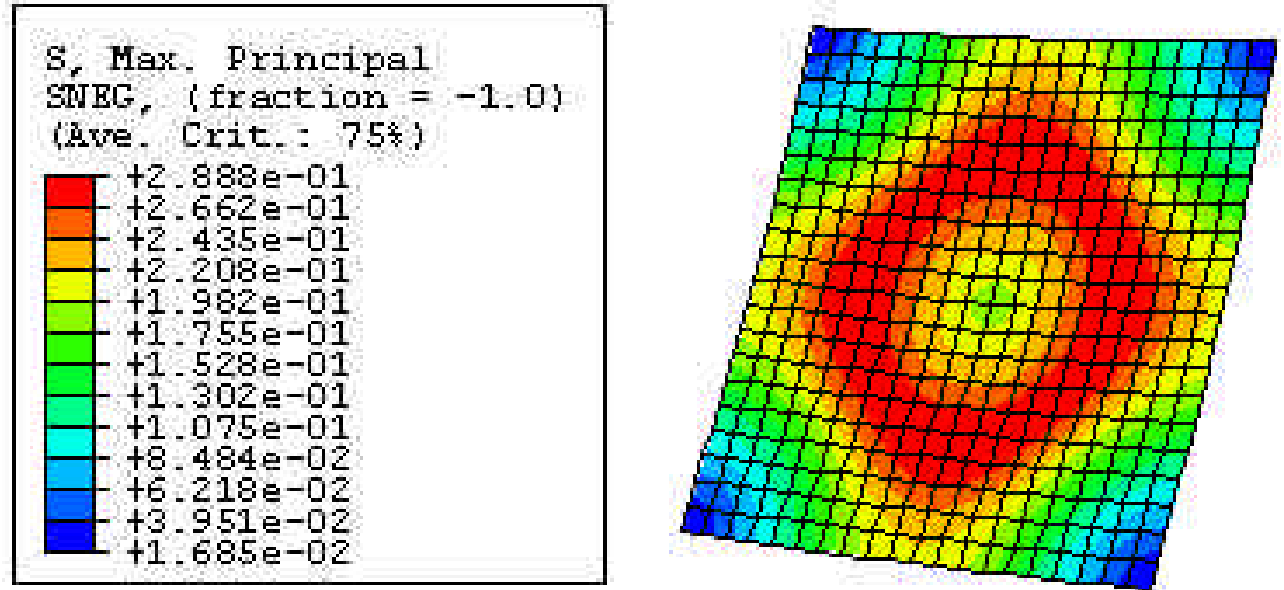

Figura 6.22 - Tensões principais, em $\mathrm{kN} / \mathrm{cm}^{2}$, na face inferior da placa de concreto armado, com força de $37,08 \mathrm{kN}$ aplicada no centro
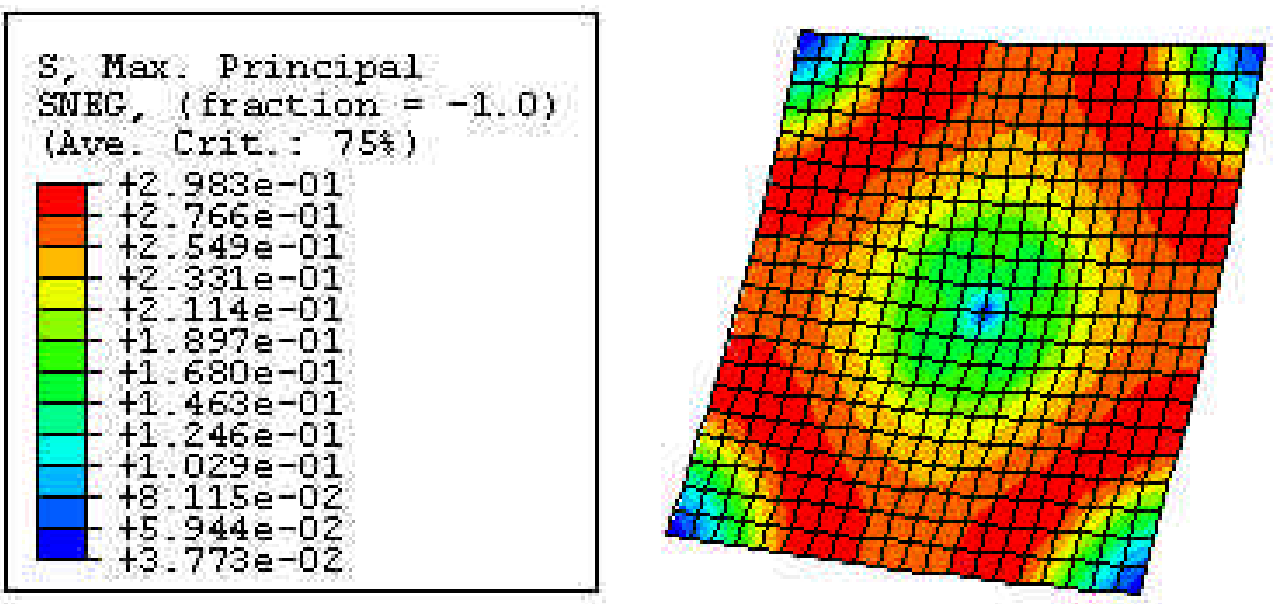

Figura 6.23 - Tensões principais, em $\mathrm{kN} / \mathrm{cm}^{2}$, na face inferior da placa de concreto armado, com força de 56,44 kN aplicada no centro
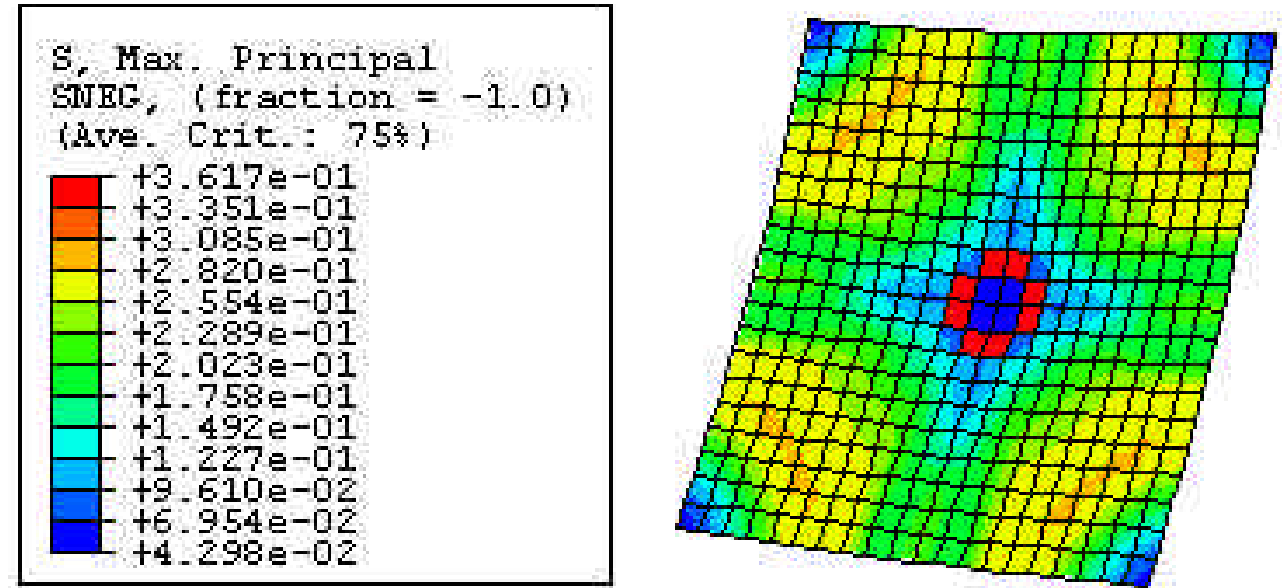

Figura 6.24 - Tensões principais, em $\mathrm{kN} / \mathrm{cm}^{2}$, na face inferior da placa de concreto armado, com força de 62,29 kN aplicada no centro 

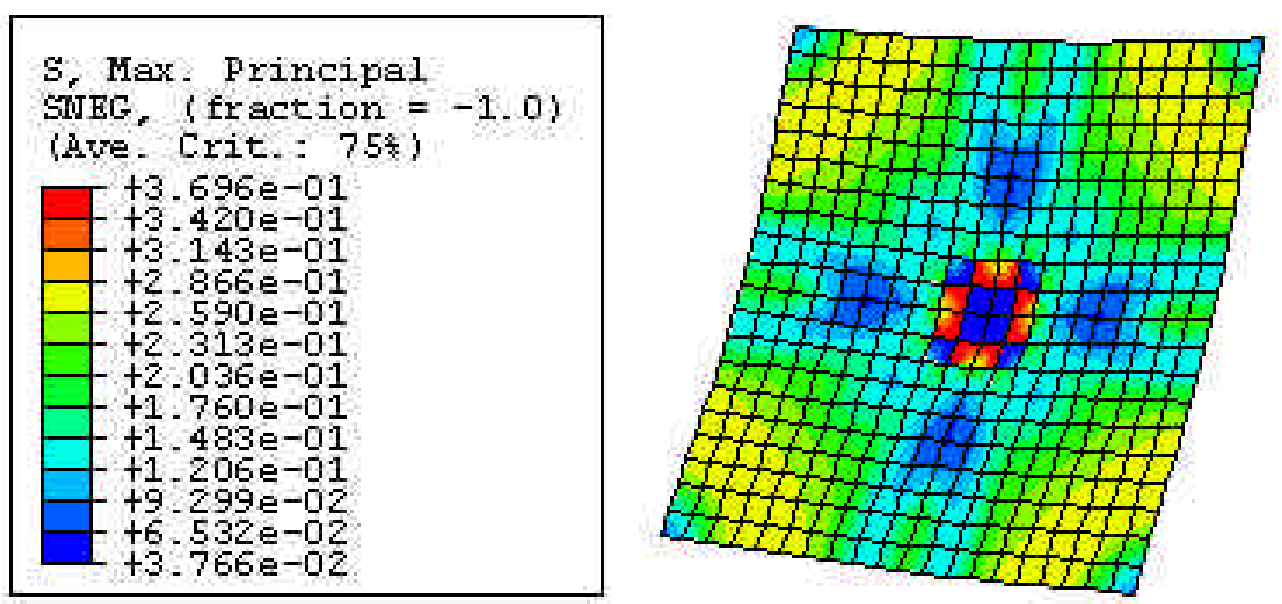

Figura 6.25 - Tensões principais, em $\mathrm{kN} / \mathrm{cm}^{2}$, na face inferior da placa de concreto armado, com força de $80,28 \mathrm{kN}$ aplicada no centro
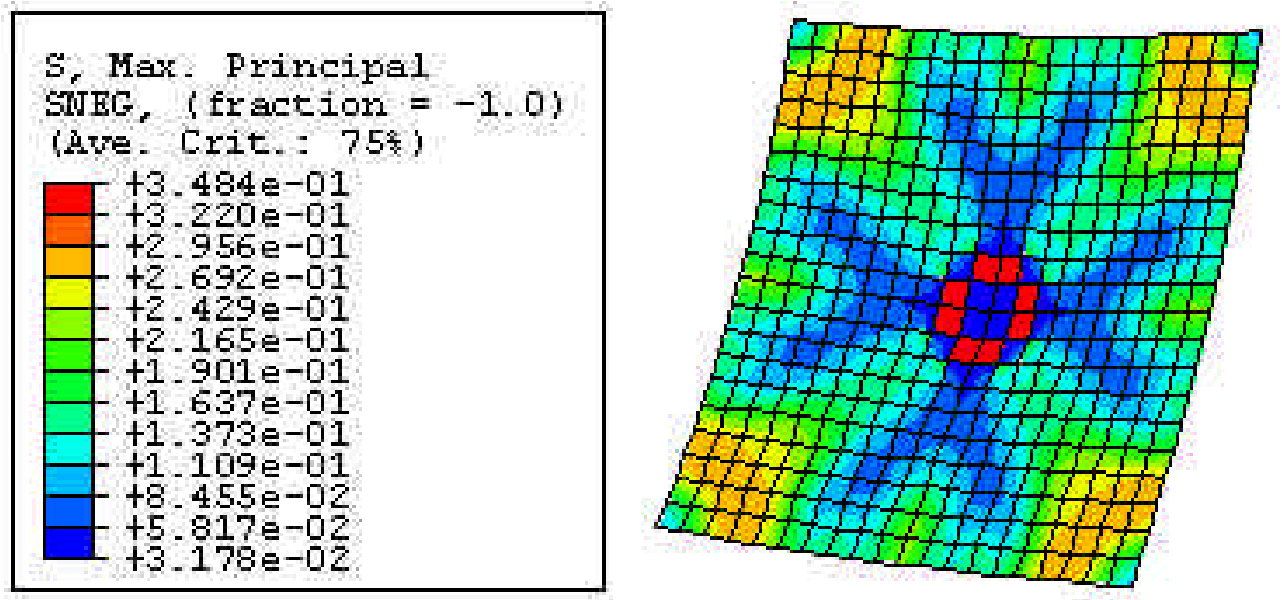

Figura 6.26 - Tensões principais, em $\mathrm{kN} / \mathrm{cm}^{2}$, na face inferior da placa de concreto armado, com força de $94,08 \mathrm{kN}$ aplicada no centro
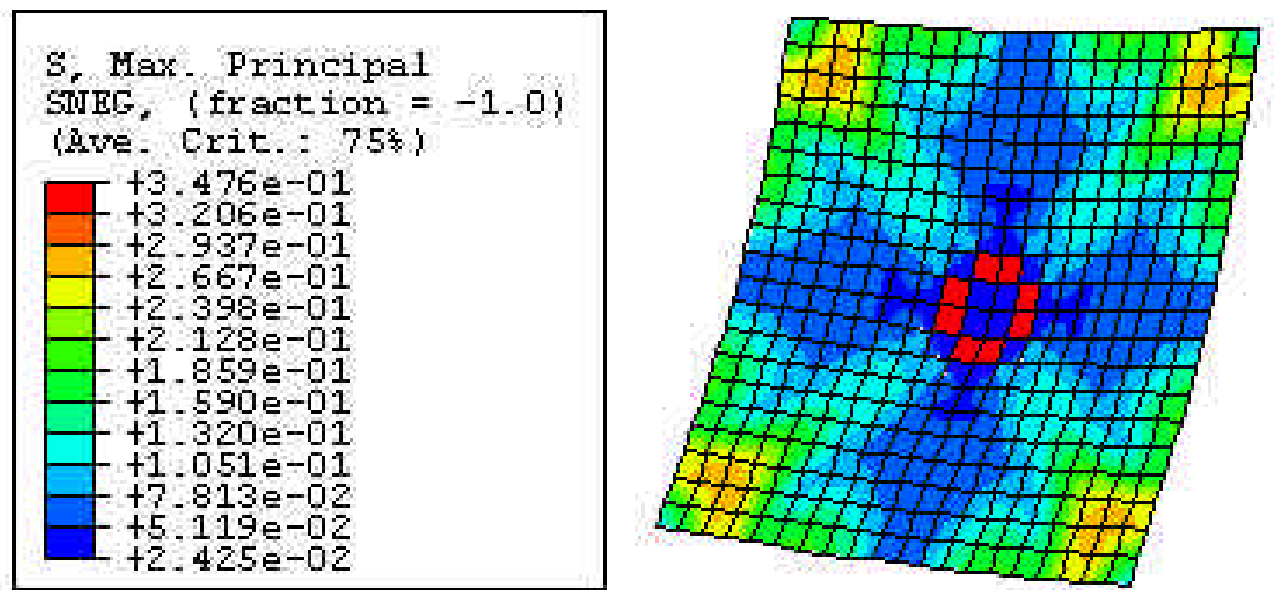

Figura 6.27 - Tensões principais, em $\mathrm{kN} / \mathrm{cm}^{2}$, na face inferior da placa de concreto armado, com força de 108,92 kN aplicada no centro 

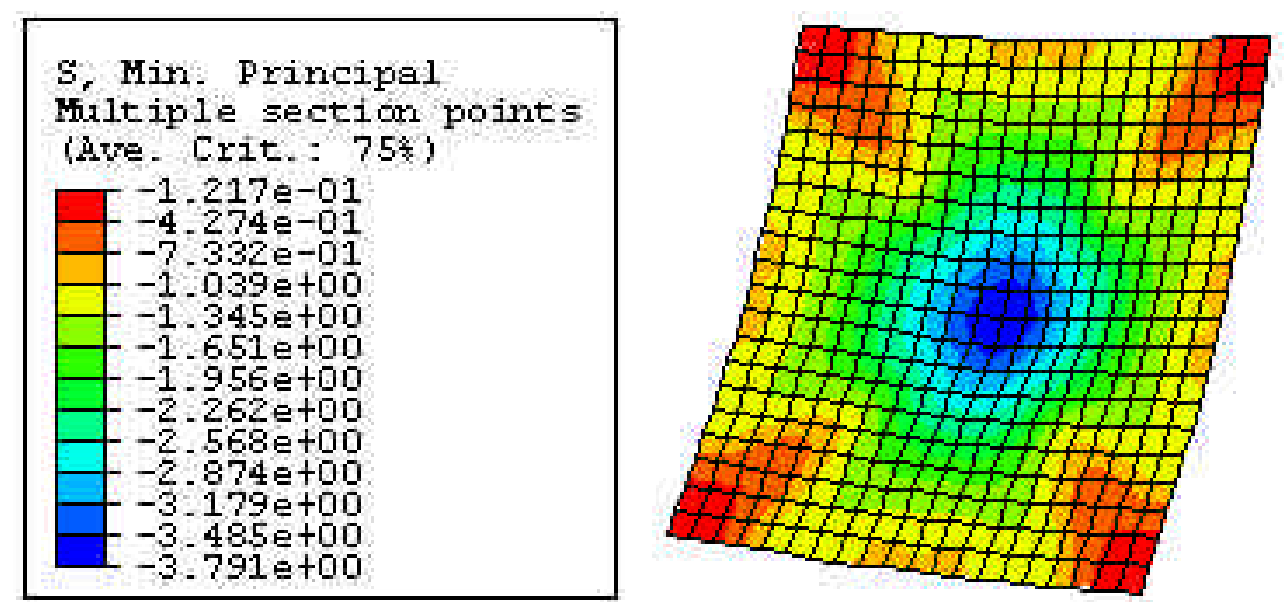

Figura 6.28 - Tensões principais, em $\mathrm{kN} / \mathrm{cm}^{2}$, na face superior da placa de concreto armado, com força de 108,92 kN aplicada no centro

No início do carregamento, há uma concentração de tensões de tração no centro da placa, na face inferior. À medida que vão aparecendo fissuras nessas áreas, ocorre um alívio das tensões e os esforços máximos se deslocam para áreas adjacentes. Ocorre então um espalhamento das fissuras, até que as tensões no centro voltam a se concentrar. As primeiras fissuras aparecem nos elementos próximos ao centro da placa, com a força aplicada de 15 kN. Com 47,49 kN', algumas fissuras já chegaram em elementos da borda da placa, e os elementos em que é aplicado o carregamento já possuem fissuras em duas direções ortogonais. Aos $62,75 \mathrm{kN}$, os elementos vizinhos à área de aplicação da força apresentam fissuras em duas direções ortogonais. A figura 6.29 mostra a propagação de fissuras, desde a força de $15 \mathrm{kN}$ até 108,92 kN.

\footnotetext{
1 No laboratório, as primeiras fissuras foram observadas nas bordas, com a força de $55 \mathrm{kN}$.
} 


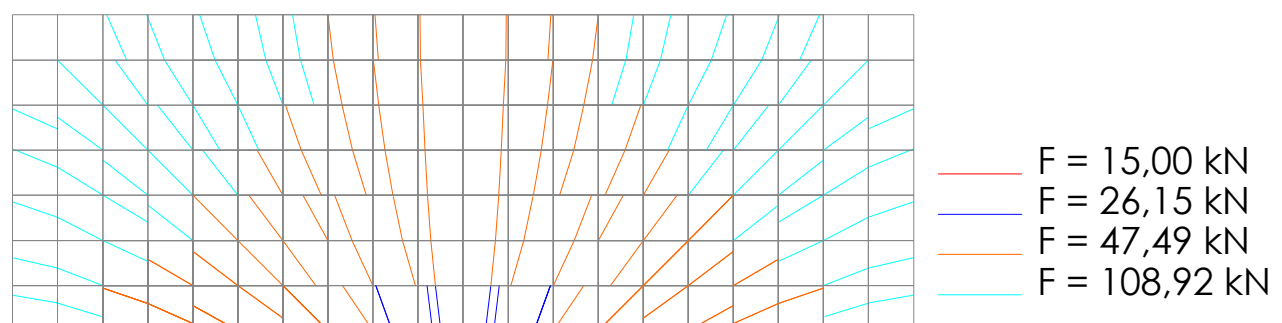

Figura 6.29 - Formação das fissuras no modelo de placa de concreto armado, com a força aplicada desde $15 \mathrm{kN}$ até 108,92 kN

A armadura atingiu a tensão de plastificação $\left(60 \mathrm{kN} / \mathrm{cm}^{2}\right)$ com a força aplicada de $77,03 \mathrm{kN}$. Nesse instante, a deformação máxima no fio era de 3,4.10-3. A deformação máxima na armadura, quando a força atingiu 108,92 kN, foi de 9,54.10-3.

\subsection{CONSIDERAÇÕES GERAIS SOBRE A MODELAGEM NUMÉRICA}

Desenvolveu-se um modelo numérico capaz de representar os principais aspectos do comportamento de placas de concreto armado apoiadas sobre o solo: a fissuração do concreto, a contribuição da armadura e o contato e a separação entre placa e fundação. Os deslocamentos, as tensões e as deformações estão compatíveis com os dados medidos em laboratório para um modelo semelhante. Conclui-se, portanto, que esta modelagem pode ser usada no estudo dos pavimentos de concreto armado.

Os valores das curvas tensão-deformação, após a fissuração do concreto, foram calibrados para quatro casos modelados numericamente e comparados com ensaios de laboratório: concreto simples e telas Q138, Q196 e Q283. Não foi encontrada uma regra que permita a extrapolação desses valores. Portanto, a 
modelagem fica limitada às taxas de armadura testadas neste trabalho. Seriam necessários novos ensaios, variando tipo e taxa de armadura, a fim de cobrir outras possibilidades. 



\section{ANÁLISE DOS RESULTADOS

Nos capítulos 5 e 6 foram mostradas as metodologias empregadas para 0 desenvolvimento de modelos experimentais e de modelos numéricos capazes de representar o comportamento de placas de concreto armado apoiadas sobre meio elástico. Também foram apresentados os resultados obtidos nos ensaios de laboratório e a validação do modelo numérico, comparando-o com modelos experimentais. Neste capítulo é feita uma análise desses resultados.

7. 1 FADIGA

Foram realizados ensaios com carregamento repetido em vigas, na primeira etapa, e em placas, na terceira etapa. Em ambas observou-se o aumento de deformação e a ruptura da armadura por efeito da fadiga.

\subsubsection{VIGAS SIMPLESMENTE APOIADAS}

A partir das relações entre força aplicada e deformação na armadura, medidas nos ensaios estáticos, determinaram-se as tensões no aço, nos ensaios dinâmicos. Esses valores são apresentados na tabela 7.1.

Os logaritmos das variações das tensões em função dos logaritmos dos número de ciclos, obtidos dos ensaios das vigas da primeira etapa, são plotados no diagrama S-N da figura 7.1, comparando os resultados com as curvas para barras retas e para barras soldadas, traçadas a partir dos valores fornecidos pela NBR 61 18:2003. 
Tabela 7.1 - Variação de tensão na armadura x número de ciclos,

nos ensaios da primeira etapa

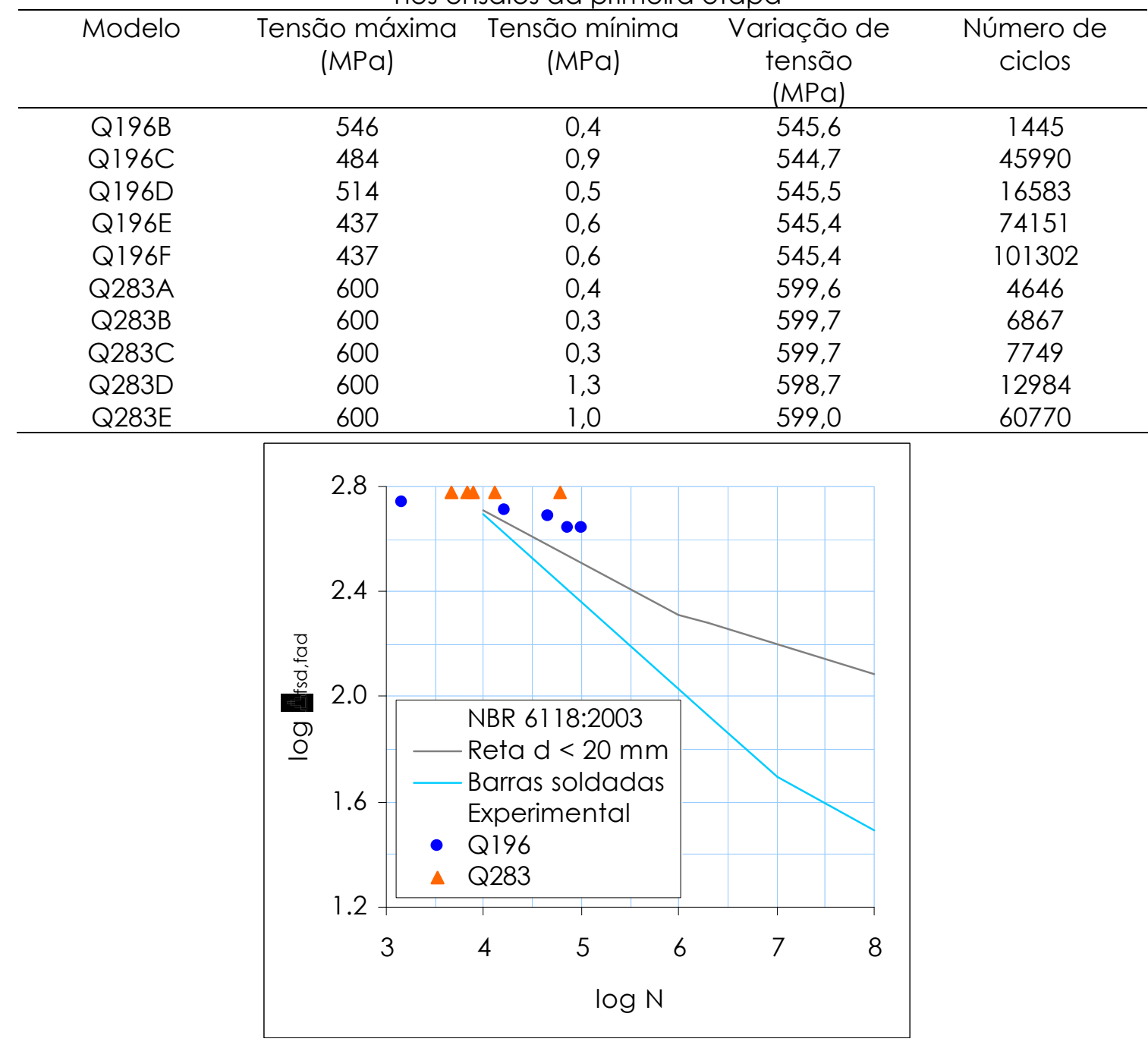

Figura 7.1 - Curvas S-N da NBR 6118:2003 x resultados experimentais da primeira etapa

Quanto maior o intervalo entre a tensão máxima e a mínima, menor o número admissível de ciclos. Nos ensaios com a tela Q283, em que é atingida a tensão de escoamento do aço, verifica-se que a resistência à fadiga é influenciada pela deformação na armadura. Na figura 7.2 são indicados os resultados de deformação - número de ciclos obtidos desses ensaios. 


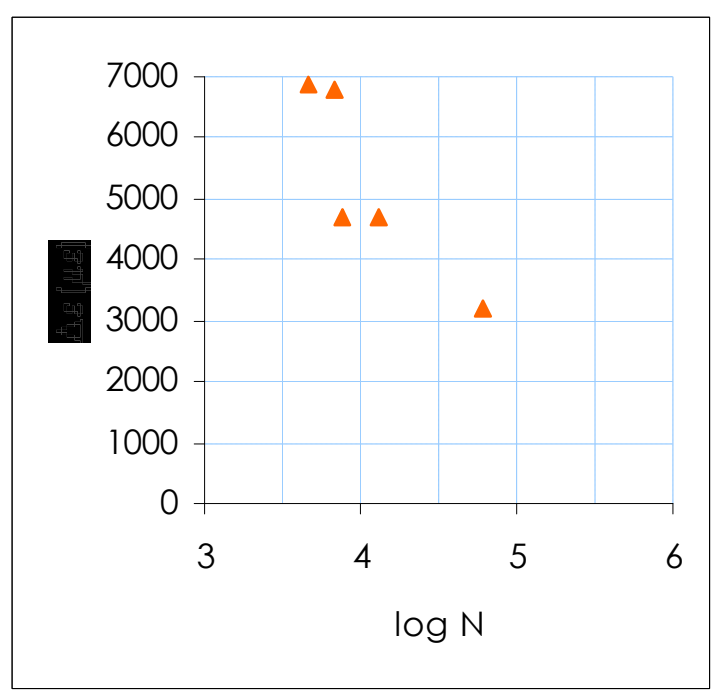

Figura 7.2 - Deformação na armadura das vigas Q283 x número de ciclos

Apesar de ter sido realizado um número reduzido de ensaios, plotando o logaritmo do número de ciclos em função da variação da deformação (em $\mu \varepsilon$ ), é possível encontrar a linha de tendência indicada na figura 7.3.

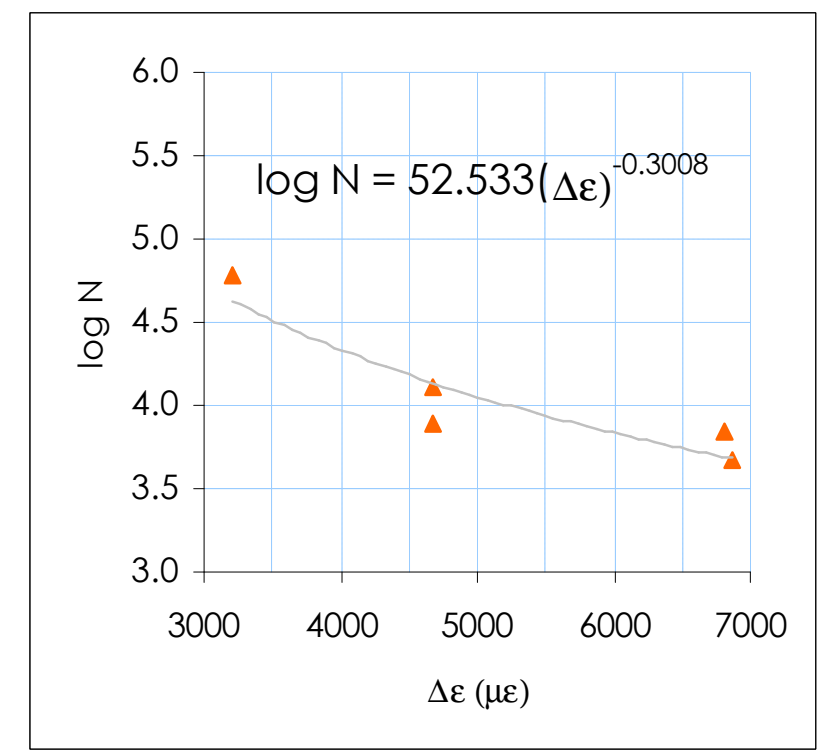

Figura 7.3 - Linha de tendência de log $N \times \varepsilon$, para vigas armadas com telas Q283

\subsubsection{PLACAS SOBRE APOIO ELÁSTICO}

Encontram-se, na literatura técnica, métodos de dimensionamento de pavimentos de concreto estruturalmente armados que desconsideram o efeito da fadiga no aço. De acordo com o que foi observado nos ensaios da terceira etapa, no capítulo 5, quando uma força é aplicada repetidas vezes sobre uma placa de concreto armado, as deformações vão aumentando até um instante em que se 
observa a ruína, sem que a força máxima, para um carregamento estático, tenha sido atingida. Verificou-se portanto que o efeito da fadiga não deve ser desconsiderado no dimensionamento de pavimentos que sejam submetidos a um grande número de ciclos de carregamento durante sua vida útil.

Utilizando o modelo desenvolvido no capítulo 6, pôde-se determinar as tensões na armadura para cada uma das forças indicadas no capítulo 5, aplicadas nos ensaios de fadiga. Assim é possível estabelecer relações com modelos de curva S-N apresentadas na literatura. No gráfico da figura 7.4, são plotadas as tensões máximas na armadura, em função da força aplicada, obtidas do modelo numérico.

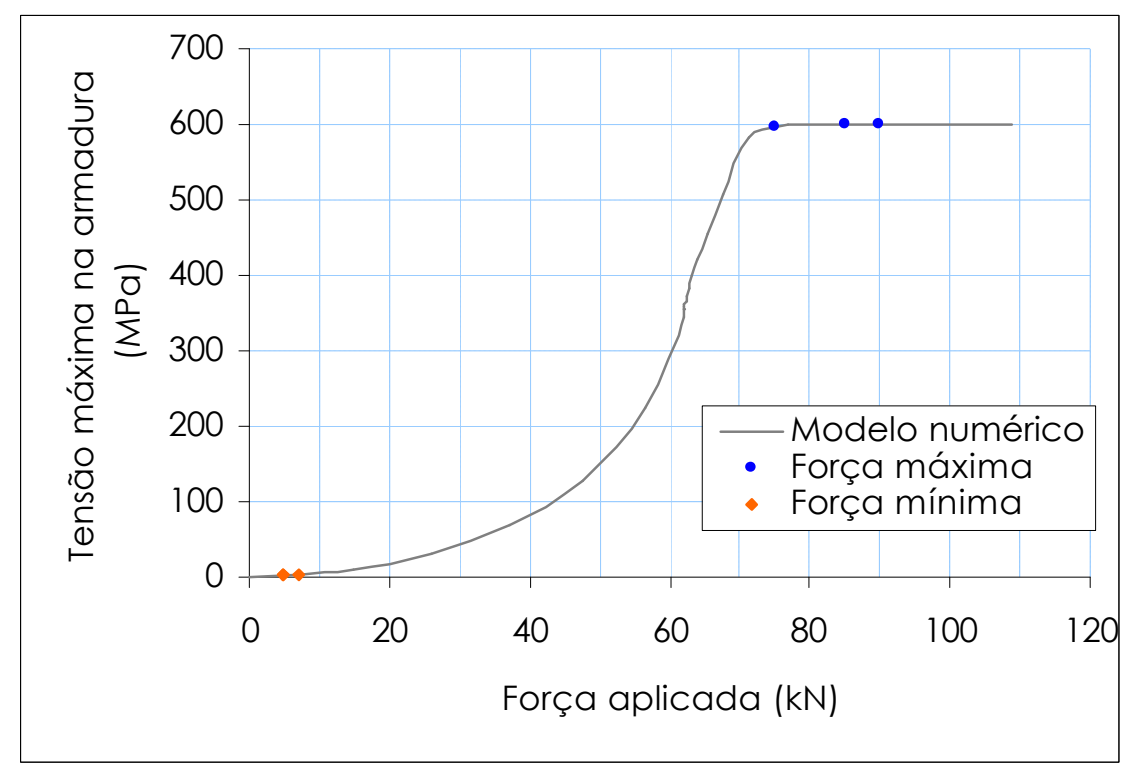

Figura 7.4 - Tensão na armadura x força aplicada

Na tabela 7.2 são listadas as tensões na armadura, para cada uma das forças aplicadas nos ensaios de fadiga, em placas de concreto armado.

Tabela 7.2 - Tensão na armadura nos ensaios de fadiga

\begin{tabular}{cccc}
\hline Modelo & PCA4 & PCA5 & PCA6 \\
\hline Força máxima (kN) & 85 & 75 & 90 \\
Força mínima (kN) & 7 & 5 & 5 \\
Tensão máxima na armadura (MPa) & 600 & 595 & 600 \\
Tensão mínima na armadura (MPa) & 5 & 4 & 4 \\
Variação de tensão (MPa) & 595 & 591 & 596 \\
Número de ciclos & 27970 & 56175 & 22880 \\
\hline
\end{tabular}

Plotando as variações de tensão e o número de ciclos obtidos dos ensaios na curva S-N traçada a partir de valores fornecidos pela NBR 6118:2003 obtém-se o gráfico da figura 7.5. 


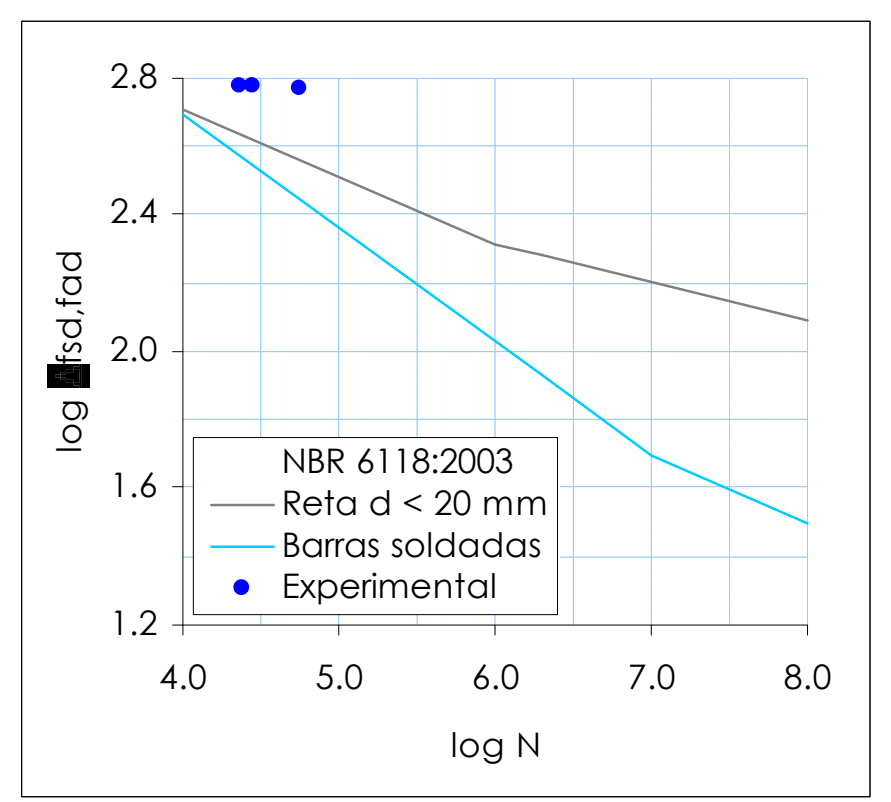

Figura 7.5 - Curvas S-N da NBR $6118 \times$ resultados experimentais

A curva de fadiga da NBR $6118: 2003$ foi determinada por meio de ensaios em barras de aço CA-50. As telas soldadas são montadas com aço CA-60.

Normalmente as curvas S-N são traçadas a partir de uma probabilidade de ruptura. A Norma não indica para qual probabilidade foram calculados os valores de sua curva.

A Norma indica que as tensões na armadura podem ser determinadas em regime elástico, compatibilizando as deformações. No caso do estudo das placas, em que seja possível uma análise numérica, é possível adotar modelo semelhante ao desenvolvido neste trabalho.

Em virtude da limitação de tempo para execução dos ensaios no laboratório, foram aplicadas apenas forças elevadas. Para traçado de uma curva S-N mais completa, seriam necessários ensaios de maior duração, com a aplicação de até $10^{8}$ ciclos. Verificou-se novamente a influência da deformação na armadura e o número admissível de ciclos. Um gráfico relacionando deformação e números de ciclos é apresentado na figura 7.6. 


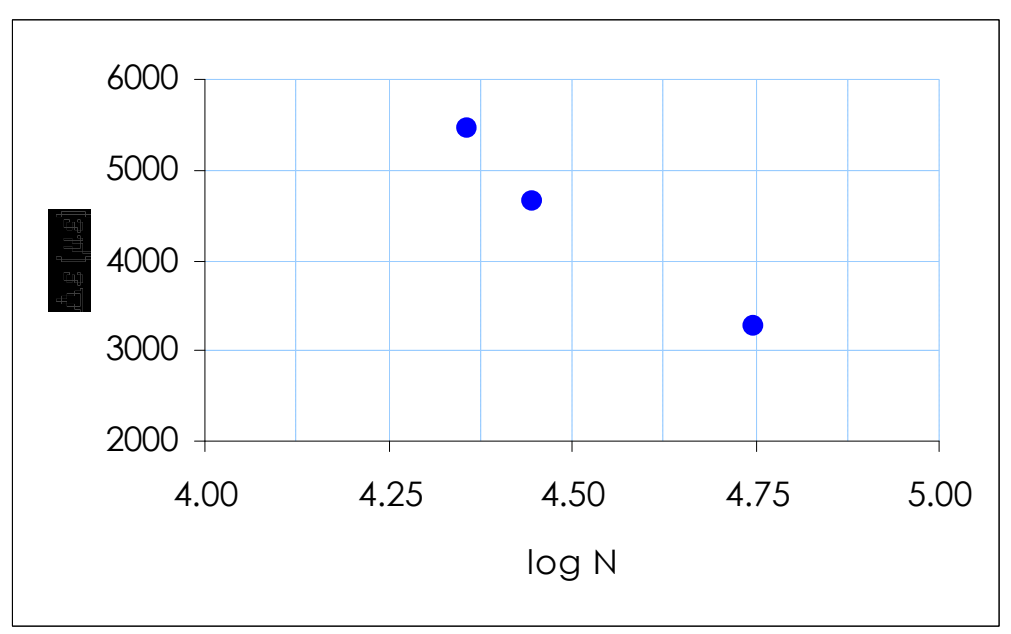

Figura 7.6 - Deformação na armadura das placas $\mathrm{x}$ número de ciclos

Plotando o logaritmo do número de ciclos em função da variação de deformação (em $\mu \varepsilon$ ), encontra-se a linha de tendência indicada na figura 7.7.

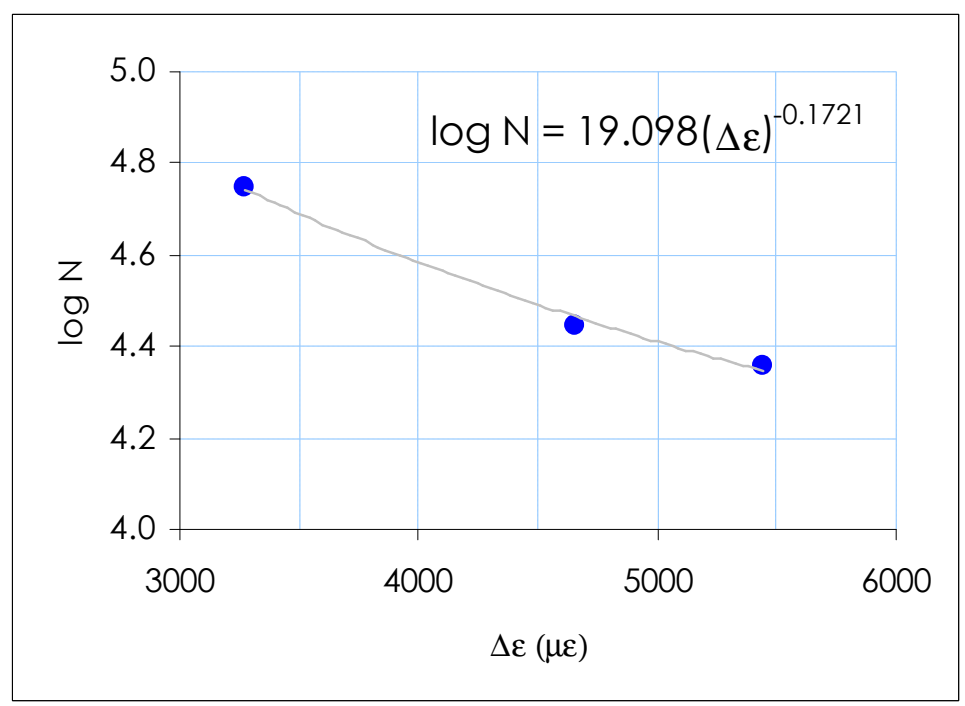

Figura 7.7 - Linha de tendência de $\log N \times \varepsilon$, para placas armadas com telas Q138

A fim de levar em conta o efeito da fadiga no dimensionamento de pavimentos de concreto estruturalmente armados, é possível determinar as tensões no aço, utilizando o modelo numérico apresentado no capítulo 6 associado à curva S-N traçada a partir dos valores experimentais. Para forças que provoquem a plastificação da armadura, é necessário relacionar o número de ciclos com a deformação, que também pode ser determinada numericamente. Não foi encontrado um modelo de fadiga em função das deformações, portanto são necessários mais ensaios com forças repetidas e tensões elevadas na armadura, a fim de se fazer um tratamento probabilístico e fornecer valores que possam ser usados no dimensionamento. 


\subsection{ANÁLISE PARAMÉTRICA}

Utilizando a modelagem desenvolvida no capítulo 6, foram avaliados alguns parâmetros que influenciam no dimensionamento de pavimentos de concreto estruturalmente armado:

- Módulo de reação - k - da fundação

- Espessura da placa-h

- Área de aço - $\mathrm{A}_{\mathrm{s}}$

- Dimensões da placa, em planta

- Posição da força

- Condições de contorno

Para todas as análises, o concreto foi adotado com resistência à tração de $3 \mathrm{MPa}$ e a armadura é posicionada a $1,5 \mathrm{~cm}$ da face inferior da placa. Na tabela 7.3 são listadas as características adotadas para os modelos numéricos desenvolvidos para estudo de cada um dos parâmetros.

Tabela 7.3 - Parâmetros adotados nas análises

\begin{tabular}{|c|c|c|c|c|c|c|c|}
\hline Parâmetro & $\begin{array}{l}\text { Comp. } \\
\text { (cm) }\end{array}$ & $\begin{array}{c}\text { Largura } \\
(\mathrm{cm})\end{array}$ & $\begin{array}{c}\mathrm{h} \\
(\mathrm{cm})\end{array}$ & Tela & $\begin{array}{c}\text { Posição } \\
\text { força }\end{array}$ & $\begin{array}{c}\mathrm{k} \\
(\mathrm{MPa} / \mathrm{m})\end{array}$ & Cont. \\
\hline $\mathrm{k}$ & 300 & 300 & 8 & Q138 & centro & $\begin{array}{l}5,20 \\
50,70\end{array}$ & isolada \\
\hline $\mathrm{h}$ & 300 & 300 & $\begin{array}{c}8,9,10 \\
11,14\end{array}$ & Q138 & centro & 20,50 & isolada \\
\hline$A_{s}$ & 300 & 300 & 10 & $\begin{array}{l}\text { Q138, } \\
\text { Q196, } \\
\text { Q283 }\end{array}$ & centro & 20,50 & isolada \\
\hline Dimensão & $\begin{array}{l}200 \\
300 \\
600\end{array}$ & $\begin{array}{l}200 \\
300 \\
300\end{array}$ & 10 & Q138 & centro & 20 & isolada \\
\hline Posição & 600 & 300 & 10 & Q138 & $\begin{array}{l}\text { centro, } \\
\text { canto, } \\
\text { borda }\end{array}$ & 20 & isolada \\
\hline $\begin{array}{l}\text { Condição } \\
\text { de } \\
\text { contorno }\end{array}$ & 600 & 300 & 10 & Q138 & $\begin{array}{l}\text { centro, } \\
\text { canto, } \\
\text { borda }\end{array}$ & 20 & $\begin{array}{l}\text { Isolada } \\
\text { Junta } 2\end{array}$ \\
\hline
\end{tabular}

Para comparação entre os modelos, são apresentados diagramas força aplicada

- deslocamento vertical e verificada a força última, definida como a força que

2 Junta com transferência de $100 \%$ do deslocamento entre duas bordas tangentes 
corresponde a uma deformação nominal de $10.10^{-3}$ na armadura, ou como a força que provoca fissuração na face superior do pavimento.

\subsection{MÓDULO DE REAÇÃO DA FUNDAÇÃO}

O módulo de reação ou coeficiente de recalque da fundação - k - representa a constante das molas que simulam o comportamento do solo. A seguir é avaliada a influência desse parâmetro em uma placa de pavimento de concreto estruturalmente armado.

Na figuras 7.8 são mostrados os deslocamentos no centro e no canto da placa, em função da força aplicada no centro, para diversos coeficientes de recalque da fundação. No gráfico, os pontos marcados com um "x" mostram o instante no qual a armadura atingiu a deformação de 10.10-3.

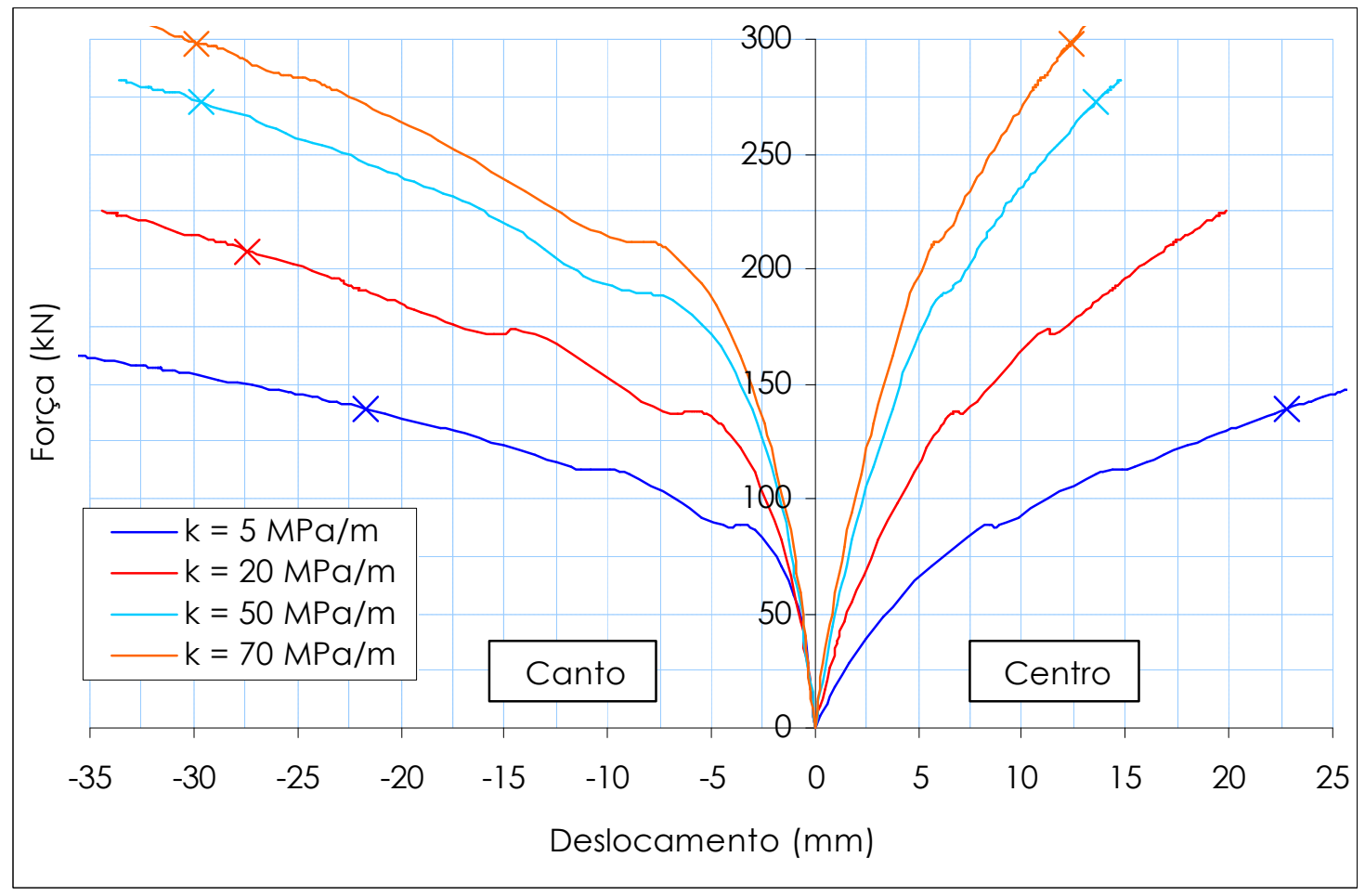

Figura 7.8 - Diagrama força-deslocamento no centro e no canto de placa isolada, para diferentes módulos de reação da fundação - $k$

Conforme aumenta o módulo de reação do solo, o deslocamento final no centro da placa diminui, enquanto o levantamento final das bordas aumenta. Para uma mesma força, tanto os deslocamentos no centro quanto no canto diminuem, para um módulo de reação maior. 
Na tabela 7.4 são apresentados as mudanças na força última, em função do aumento da capacidade do solo.

Tabela 7.4 - Relação entre incrementos no k e na força

\begin{tabular}{cccccc}
\hline $\begin{array}{c}\mathrm{k}_{1} \\
(\mathrm{MPa} / \mathrm{m})\end{array}$ & $\begin{array}{c}\mathrm{k}_{2} \\
(\mathrm{MPa} / \mathrm{m})\end{array}$ & $\begin{array}{c}\text { Diferença } \\
\text { entre } \mathrm{k}(\%)\end{array}$ & $\begin{array}{c}\mathrm{F}_{u} \text { para k } \\
(\mathrm{kN})\end{array}$ & $\begin{array}{c}\mathrm{F}_{u} \text { para k2 } \\
(\mathrm{kN})\end{array}$ & $\begin{array}{c}\text { Diferença } \\
\text { entre } \mathrm{F}_{\cup}(\%)\end{array}$ \\
\hline 5 & 20 & 300 & 139,12 & 207,84 & 49 \\
20 & 50 & 150 & 207,84 & 272,31 & 31 \\
50 & 70 & 40 & 272,31 & 298,39 & 10 \\
20 & 70 & 250 & 207,84 & 298,39 & 44 \\
\hline
\end{tabular}

Verifica-se que, a relação incremento de força - incremento de k não é linear e depende também do valor inicial do coeficiente de recalque da fundação. Para coeficientes iniciais menores o acréscimo em $\mathrm{k}$ (em \%) representa um aumento maior na resistência que no caso de coeficiente de recalque inicial maior.

Para mudar o valor de k de 20 MPa para 50 MPa é necessária, por exemplo, uma camada de sub-base de aproximadamente $12 \mathrm{~cm}$ de solo melhorado com cimento ou $7 \mathrm{~cm}$ de concreto rolado 3 .

\subsubsection{ESPESSURA DA PLACA}

Conforme aumenta a espessura da placa, a força que provoca a fissuração do concreto e a altura útil da placa aumentam. Com a modelagem numérica é possível quantificar o ganho na força última, em função do aumento da espessura.

Nas figuras 7.9 são mostrados os deslocamentos no centro e no canto da placa, para espessuras entre 8 e $14 \mathrm{~cm}$ e coeficiente de recalque da fundação de $20 \mathrm{MP} / \mathrm{m}$, e nas figuras 7.10 , para coeficiente de $50 \mathrm{MPa} / \mathrm{m}$.

3 Valores calculados a partir de tabelas fornecidas em RODRIGUES e PITTA (s.d.) 


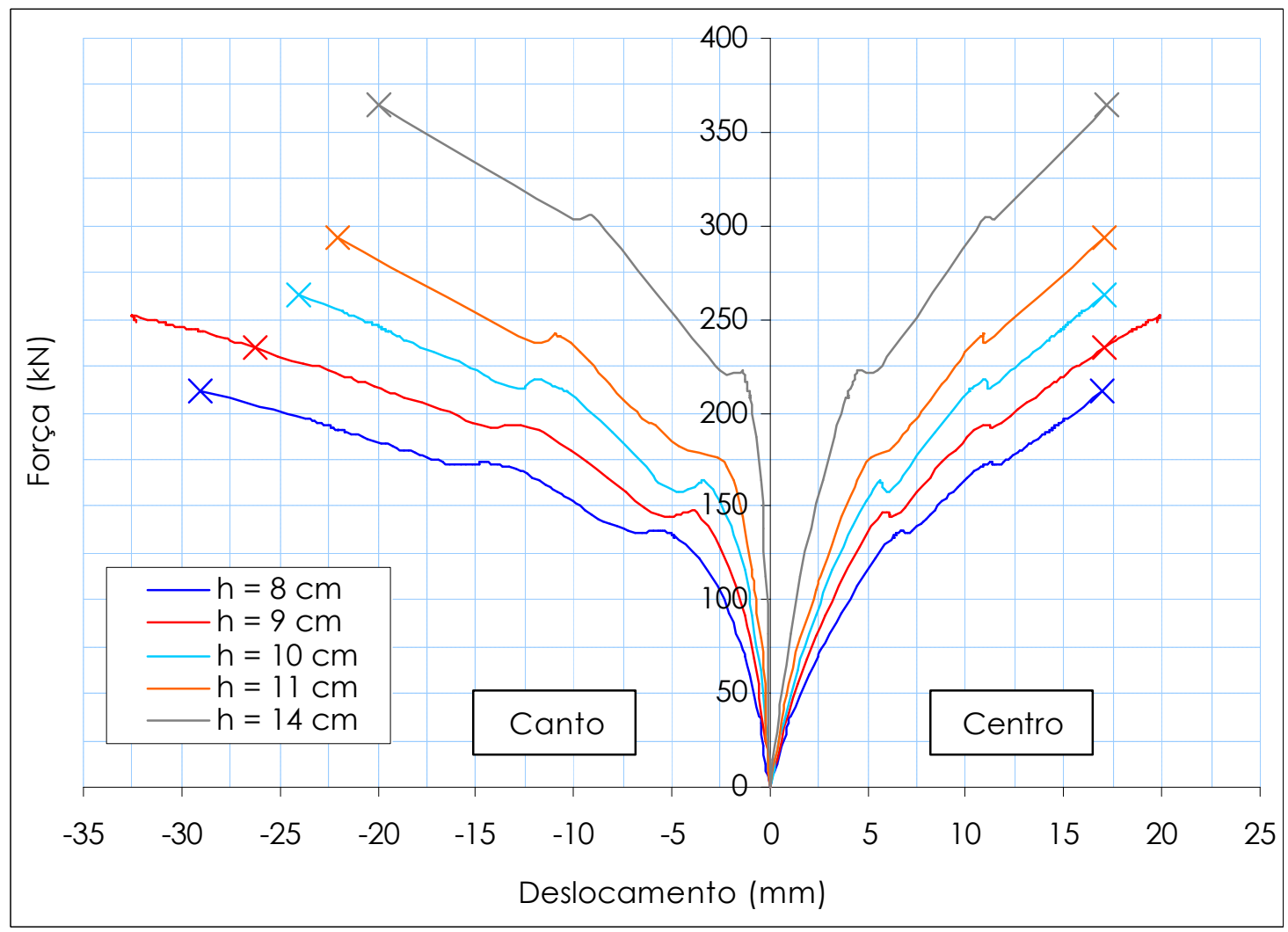

Figura 7.9 - Diagrama força-deslocamento no centro e no canto de placa isolada, com diferentes espessuras e $\mathrm{k}=20 \mathrm{MPa} / \mathrm{m}$ 


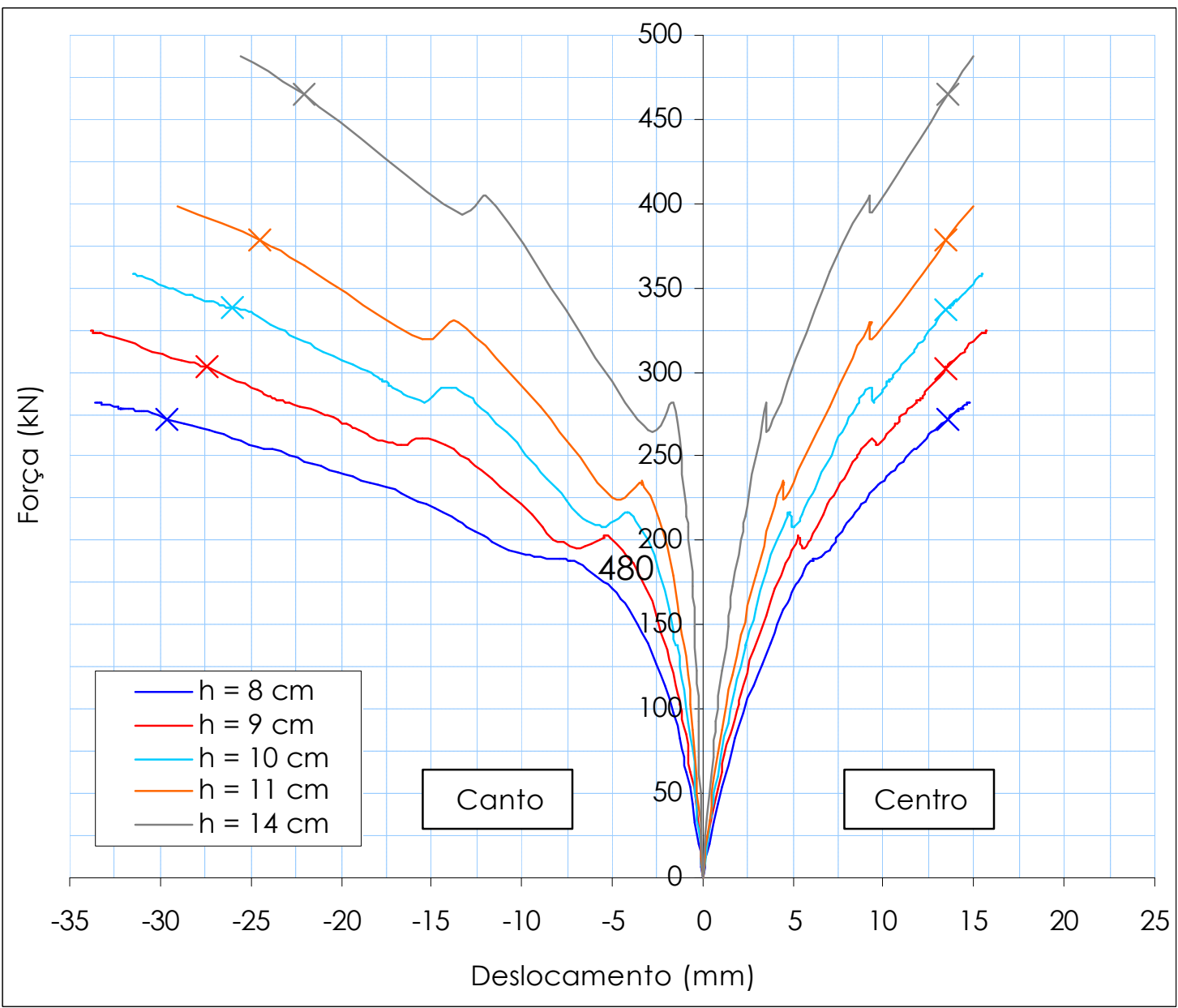

Figura 7.10 - Diagrama força - deslocamento no centro e no canto de placa isolada, com diferentes espessuras e $\mathrm{k}=50 \mathrm{MPa} / \mathrm{m}$

Na figura 7.11 são comparados os diagramas força - deslocamento, para as espessuras de $8 \mathrm{~cm}$ e $14 \mathrm{~cm}$ e coeficiente de recalque de $20 \mathrm{MPa} / \mathrm{m}$ e $50 \mathrm{MPa} / \mathrm{m}$. 


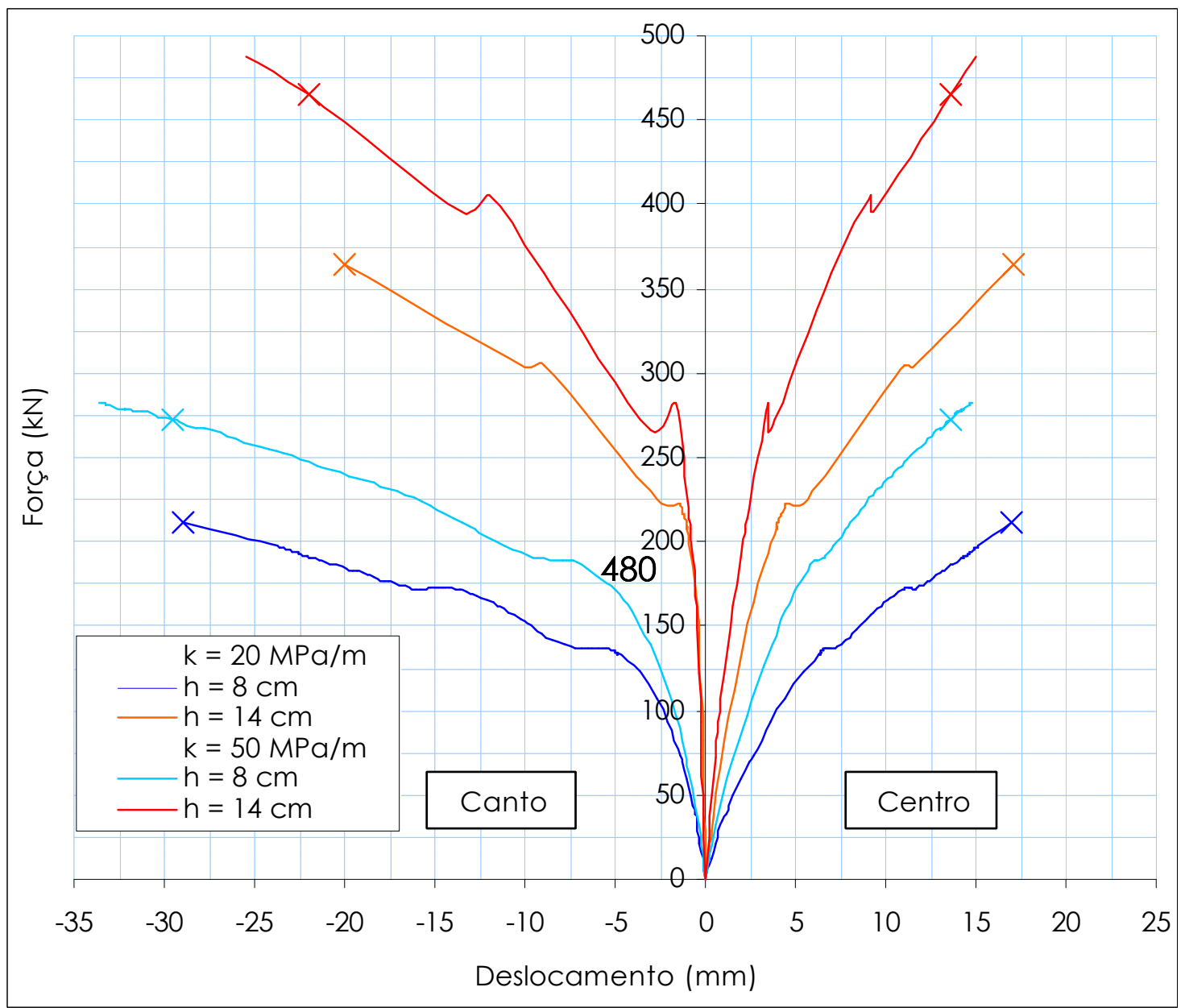

Figura 7.11 - Diagrama força-deslocamento no centro e no canto de placa isolada, $\mathrm{com} \mathrm{h}=8 \mathrm{~cm}$ e $14 \mathrm{~cm}$ e $\mathrm{k}=20 \mathrm{MPa} / \mathrm{m}$ e $50 \mathrm{MPa} / \mathrm{m}$

O acréscimo da espessura tem efeito semelhante, nas duas capacidades de suporte do solo. Na tabela 7.5 são apresentados os ganhos na força última em função do aumento da espessura da placa.

Tabela 7.5 - Relação entre incrementos na espessura e na força última

\begin{tabular}{cccccc}
\hline $\begin{array}{c}\mathrm{h}_{1} \\
(\mathrm{~cm})\end{array}$ & $\begin{array}{c}\mathrm{h}_{2} \\
(\mathrm{~cm})\end{array}$ & $\begin{array}{c}\text { Diferença } \\
\text { entre } \mathrm{h}(\%)\end{array}$ & $\begin{array}{c}\mathrm{F}_{\cup} \text { para } \mathrm{h}_{1} \\
(\mathrm{kN})\end{array}$ & $\begin{array}{c}\mathrm{F}_{\cup} \text { para } \mathrm{h}_{2} \\
(\mathrm{kN})\end{array}$ & $\begin{array}{c}\text { Diferença } \\
\text { entre } \mathrm{F}_{\cup}(\%)\end{array}$ \\
\hline 8 & 9 & 13 & 211,07 & 234,29 & 11 \\
9 & 10 & 11 & 234,29 & 262,99 & 12 \\
10 & 11 & 10 & 262,99 & 294,00 & 12 \\
11 & 14 & 27 & 294,00 & 364,98 & 24 \\
8 & 14 & 75 & 211,07 & 364,98 & 73 \\
\hline 8 & 9 & 13 & 270,66 & 302,76 & 12 \\
9 & 10 & 11 & 301,86 & 337,74 & 12 \\
10 & 11 & 10 & 337,74 & 378,27 & 12 \\
11 & 14 & 27 & 378,27 & 465,27 & 23 \\
8 & 14 & 75 & 270,66 & 465,27 & 72 \\
\hline
\end{tabular}


Observa-se, para o modelo estudado, uma relação linear entre o incremento na espessura e o aumento de força última, que pode ser aproximada pela equação:

$y=1,05 \cdot x-0,29$

sendo:

- $x$ : incremento na força última, em \%

- $y$ : incremento na espessura da placa, em \%

\subsection{3 ÁREA DE AÇO}

Na figura 7.12 e 7.13 são mostrados os deslocamentos no centro e no canto da placa, para as três áreas de aço avaliadas mais a placa sem armadura, para os coeficientes de recalque da fundação de $20 \mathrm{MPa} / \mathrm{m}$ e $50 \mathrm{MPa} / \mathrm{m}$.

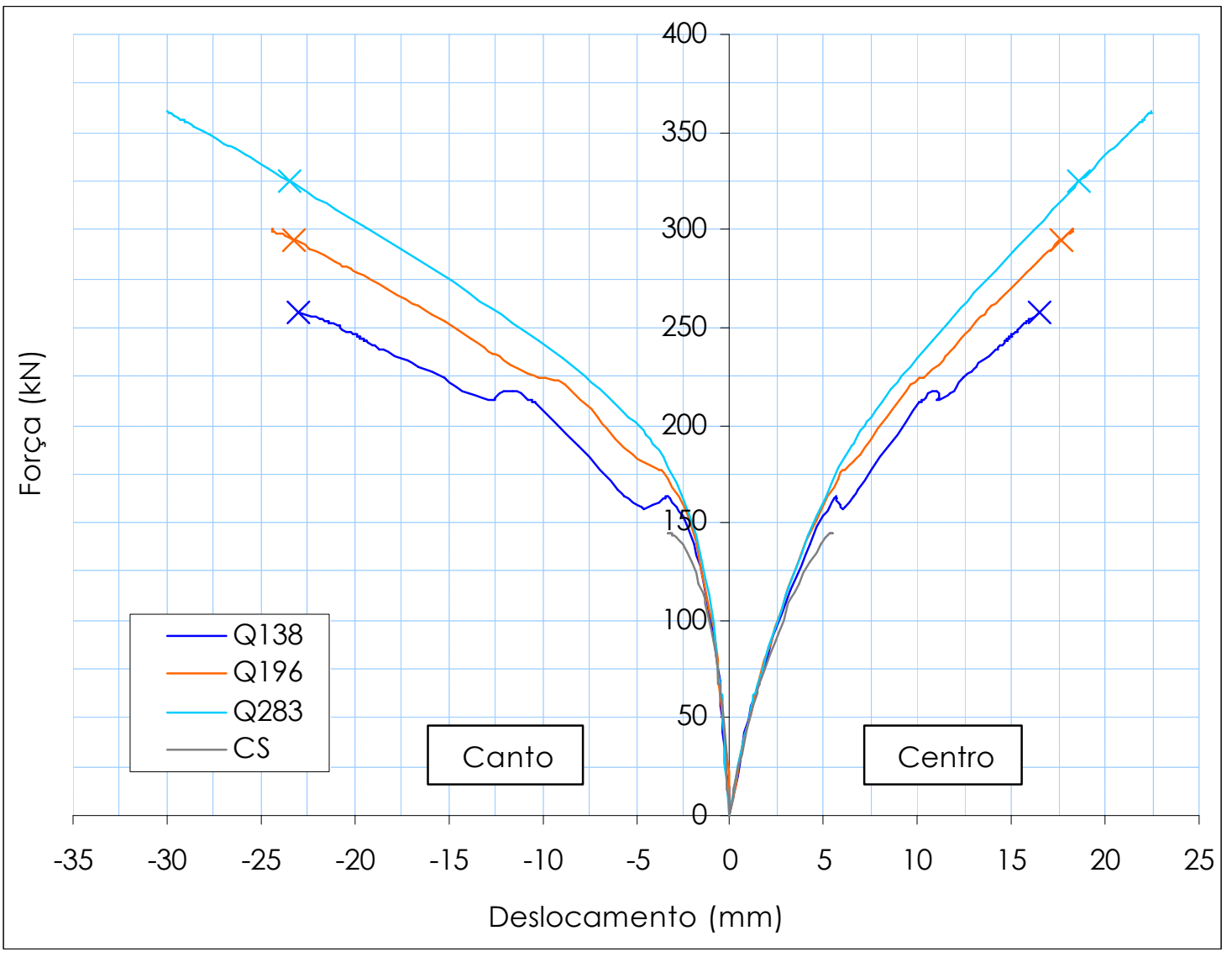

Figura 7.12 - Diagrama força- deslocamento no centro e no canto de placa isolada, com diferentes áreas de aço, $\mathrm{k}=20 \mathrm{MPa} / \mathrm{m}$ 


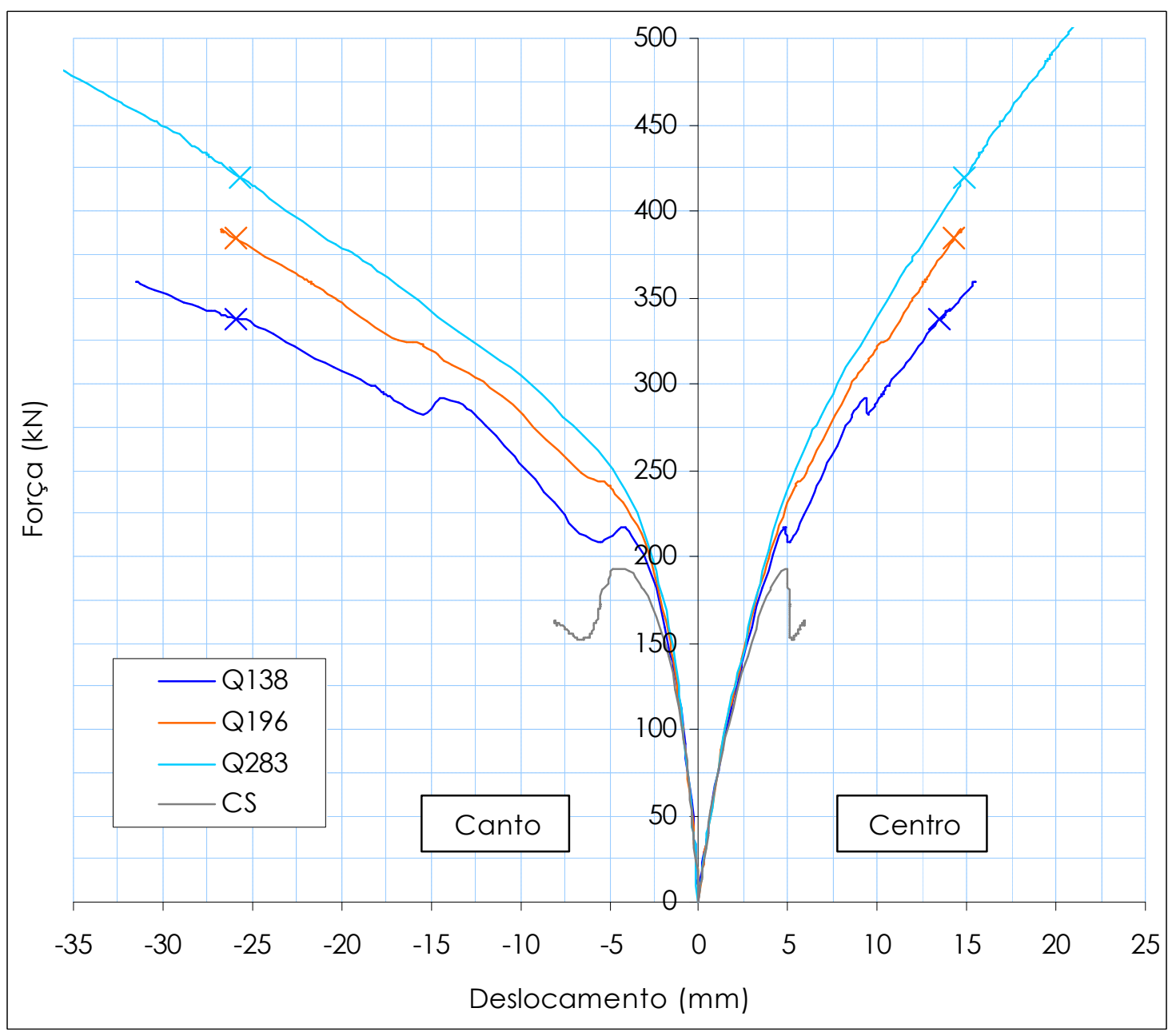

Figura 7.13 - Diagrama força - deslocamento no centro e no canto de placa isolada, com diferentes áreas de aço, $\mathrm{k}=50 \mathrm{MPa} / \mathrm{m}$

Nota-se que os deslocamentos da placa são pouco influenciados pela área de aço. Há um pequeno ganho da força com o aumento da taxa de armadura. Na tabela 7.6 são comparados os incrementos na área de aço com as ganhos na força última.

Tabela 7.6 - Relação entre incrementos na área de aço e na força última

\begin{tabular}{cccccc}
\hline $\begin{array}{c}A_{s 1} \\
\left(\mathrm{~cm}^{2} / \mathrm{m}\right)\end{array}$ & $\begin{array}{c}A_{s 2} \\
\left(\mathrm{~cm}^{2} / \mathrm{m}\right)\end{array}$ & $\begin{array}{c}\text { Diferença } \\
\text { entre } A_{s}(\%)\end{array}$ & $\begin{array}{c}F_{u} \text { para } A_{s 1} \\
(\mathrm{kNN})\end{array}$ & $\begin{array}{c}F_{u} \text { para } A_{s 2} \\
(\mathrm{kN})\end{array}$ & $\begin{array}{c}\text { Diferença } \\
\text { entre } F_{\cup}(\%)\end{array}$ \\
\hline 1,38 & 1,96 & 42 & 258,05 & 294,49 & 14 \\
1,96 & 2,83 & 44 & 294,49 & 324,38 & 10 \\
1,38 & 2,83 & 105 & 258,05 & 324,38 & 26 \\
\hline \multicolumn{7}{c}{ Para $\mathrm{k}=50 \mathrm{MPa} / \mathrm{m}$} \\
\hline 1,38 & 1,96 & 42 & 337,74 & 384,13 & 14 \\
1,96 & 2,83 & 44 & 384,13 & 419,81 & 9 \\
1,38 & 2,83 & 105 & 337,74 & 419,81 & 24 \\
\hline
\end{tabular}

Se não houvesse armadura alguma, a força última no modelo com coeficiente de recalque igual a $50 \mathrm{MPa} / \mathrm{m}$ seria de 192 kN. Portanto, a introdução das telas Q138, 
Q196 e Q283 proporciona aumento de força de 75\%, $100 \%$ e 119\%, respectivamente.

\subsubsection{DIMENSÕES DA PLACA}

Yoder \& Witczak (1975) apresentaram cartas de influência desenvolvidas por Pickett \& Ray, em 1951, que permitem a determinação de momentos fletores em placas de concreto apoiadas sobre líquido denso, para diversas configurações do carregamento. O momento é determinado em função da força atuante, da pressão dos pneus, da distância entre rodas e do raio de rigidez da placa, dado por:

$$
\ell=\sqrt[4]{\frac{E \cdot h^{3}}{12 \cdot\left(1-v^{2}\right) \cdot k}}, \text { em m }
$$

sendo:

- E: módulo de elasticidade do concreto, em MPa

- h: espessura da placa, em m

- $\quad v$ : coeficiente de Poisson

- $\mathrm{k}$ : coeficiente de recalque da fundação, em MPa/m

Verifica-se que esse método não leva em consideração as dimensões da placa, em planta, pois foi desenvolvido para placa semi-infinita.

Na figura 7.14 são plotados os diagramas força - deslocamento no centro e no canto da placa obtidos dos três modelos com diferentes dimensões em planta. 


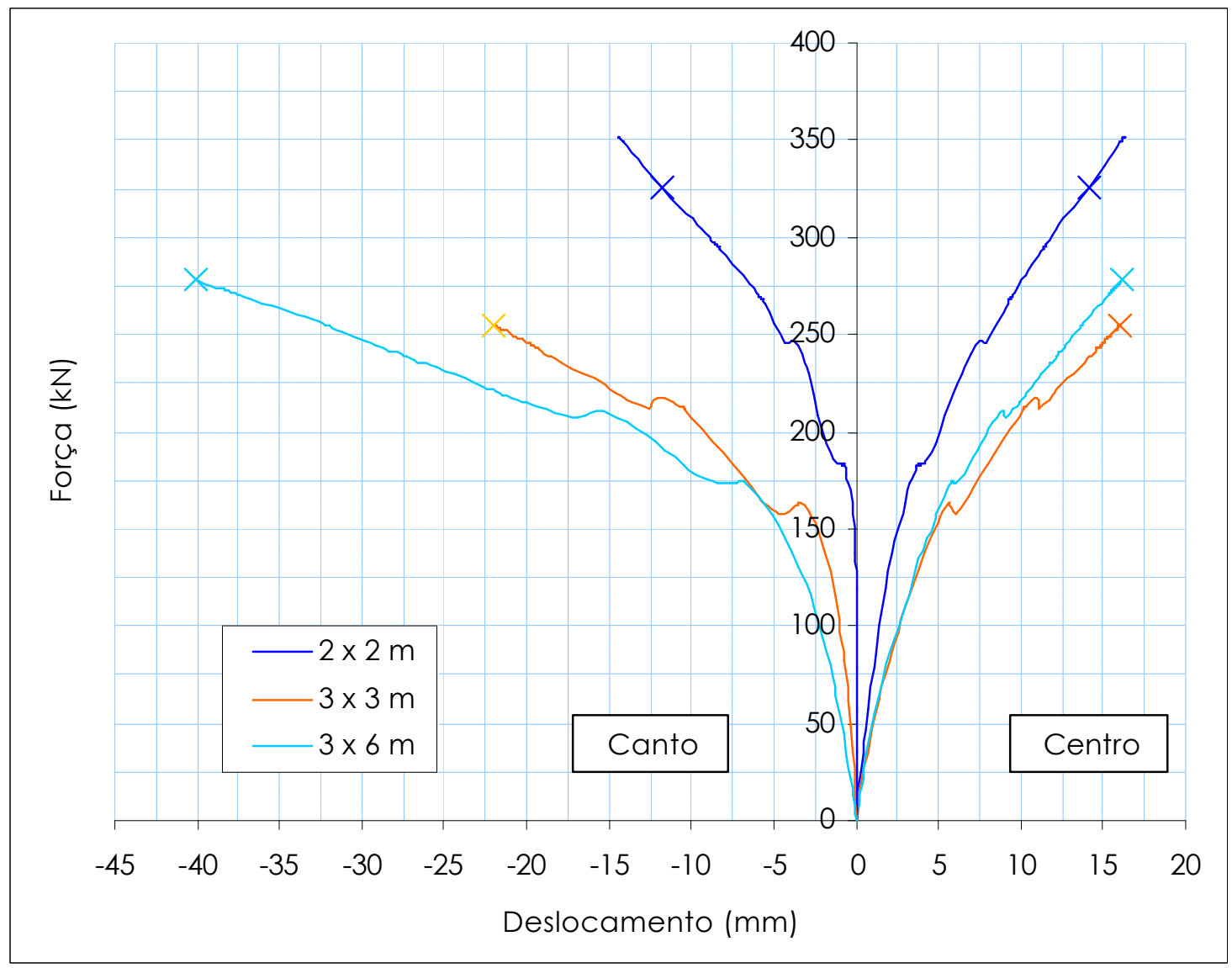

Figura 7.14 - Diagrama força - deslocamento no centro de placa isolada, com diferentes dimensões em planta

Na tabela 7.7 são mostradas as diferenças na força última, obtidas para diferentes dimensões da placa.

Tabela 7.7 - Relação entre dimensões da placa e força última

\begin{tabular}{ccccc}
\hline $\begin{array}{c}\operatorname{Dim}_{1} \\
(\mathrm{~m} \times \mathrm{m})\end{array}$ & $\begin{array}{c}\operatorname{Dim}_{2} \\
(\mathrm{~m} \times \mathrm{m})\end{array}$ & $\begin{array}{c}F_{u} \text { para Dim} \\
(\mathrm{kN})\end{array}$ & $\begin{array}{c}F_{u} \text { para Dim } \\
(\mathrm{kN})\end{array}$ & $\begin{array}{c}\text { Diferença entre } F_{u} \\
(\%)\end{array}$ \\
\hline $3 \times 3$ & $3 \times 6$ & 254,30 & 278,15 & 9 \\
$3 \times 6$ & $2 \times 2$ & 278,15 & 325,87 & 17 \\
$3 \times 3$ & $2 \times 2$ & 254,30 & 325,87 & 28 \\
\hline
\end{tabular}

Verifica-se que, para mesma espessura e mesma área de aço, as dimensões em planta influenciam substancialmente os esforços na placa. Para os modelos estudados foi encontrada diferença de até $28 \%$ na força última. No caso de placas isoladas e com uma única área de aplicação de força, a consideração de placa semi-infinita está a favor da segurança, pois a resistência das placas menores é maior. 


\subsubsection{POSIÇÃO DA FORÇA E CONDIÇÕES DE CONTORNO}

Os esforços na placa também dependem da posição onde a força é aplicada. Na figura 7.15 são plotados os deslocamentos máximos na placa, para cada uma das posições de aplicação da força. O símbolo "o" indica o ponto de plastificação da armadura.

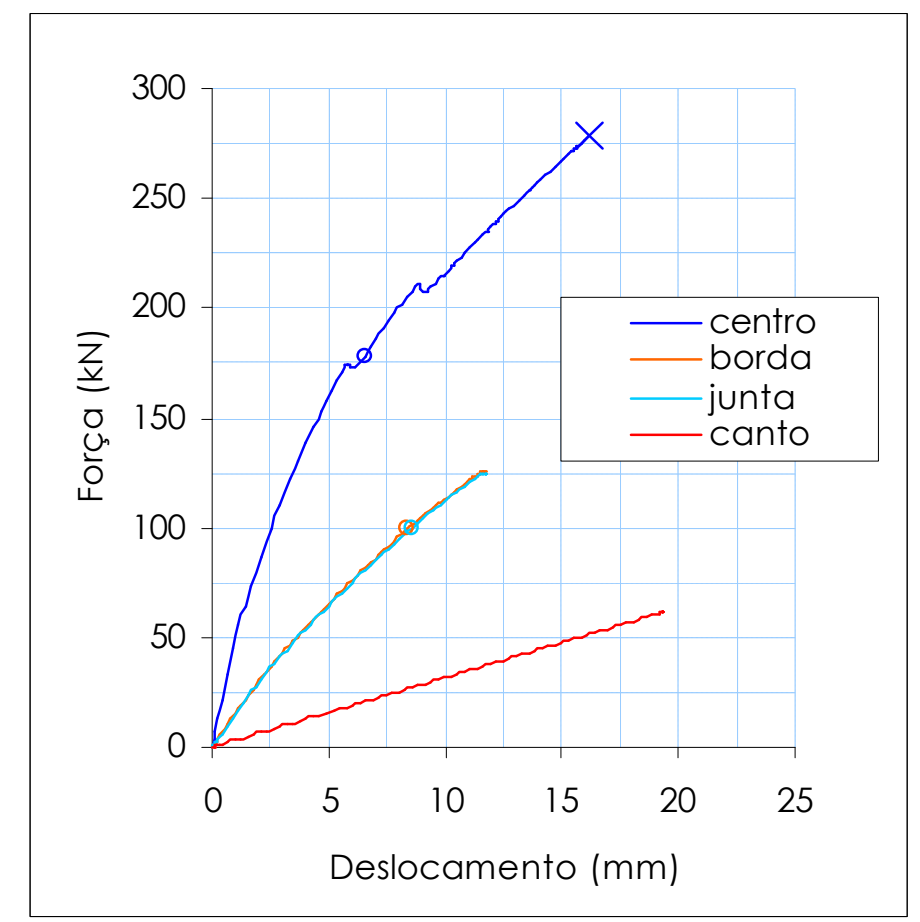

Figura 7.15 - Diagrama força-deslocamento no canto de placa isolada, com diferentes posições da força

Verifica-se que, para a geometria estudada, a força que provoca a plastificação da armadura é $68 \%$ maior quando a força é aplicada no centro da placa, se comparada com a força na borda ou na junta sem dispositivos de transferência de deslocamentos. Quando a força na borda ou na junta atinge $125 \mathrm{kN}$, aparecem fissuras de tração na face superior da placa. As tensões na face superior da placa, com força na junta e na borda, estão apresentadas nas figuras 7.16 e 7.17 , respectivamente. 


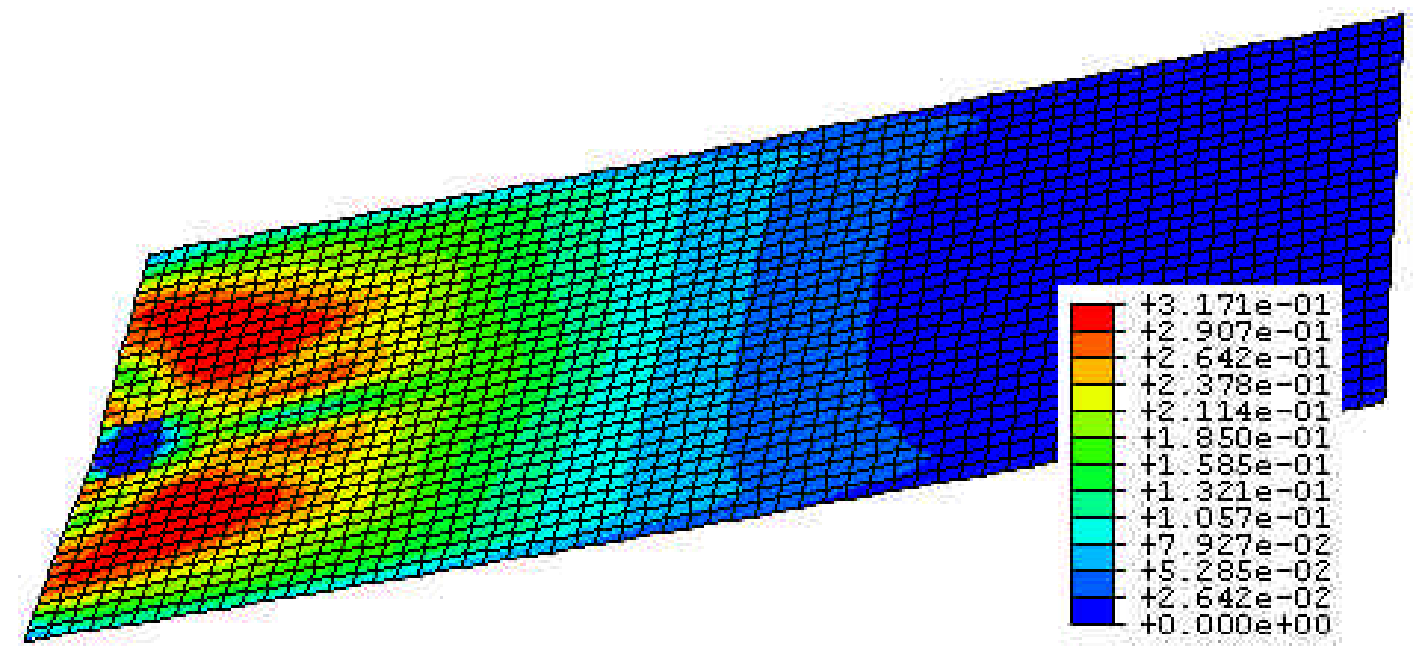

Figura 7.16 - Distribuição das tensões $\left(\mathrm{kN} / \mathrm{cm}^{2}\right)$ na face superior da placa isolada, com força de $125 \mathrm{kN}$, na junta

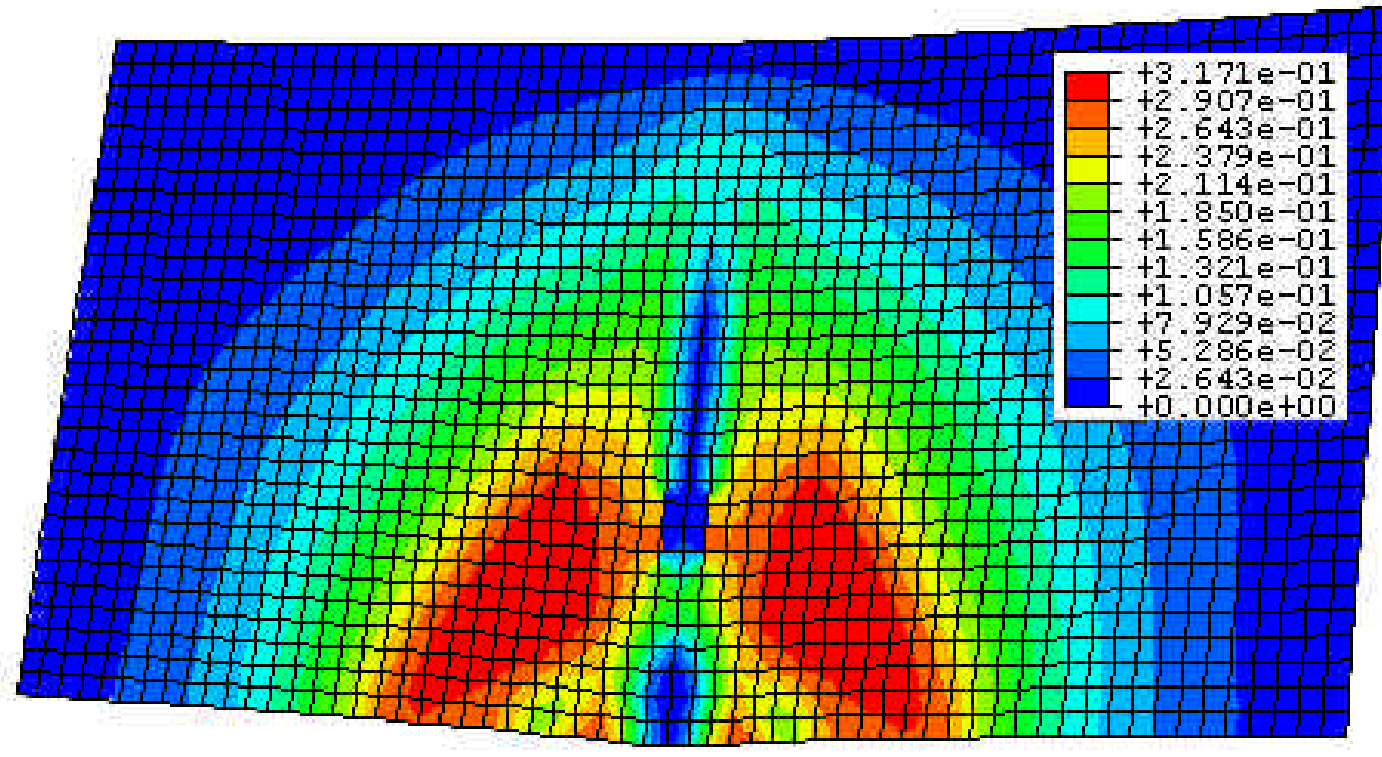

Figura 7.17 - Distribuição das tensões $\left(\mathrm{kN} / \mathrm{cm}^{2}\right)$ na face superior da placa isolada, com força de $125 \mathrm{kN}$, na borda

No caso da força aplicada no canto de uma placa isolada as tensões na armadura se mantêm muito abaixo da plastificação, e são introduzidas pequenas tensões de tração na face superior, conforme é mostrado na figura 7.18. O deslocamento vertical é grande, mesmo para pequenas forças, pois o solo não oferece resistência ao descolamento da placa. 


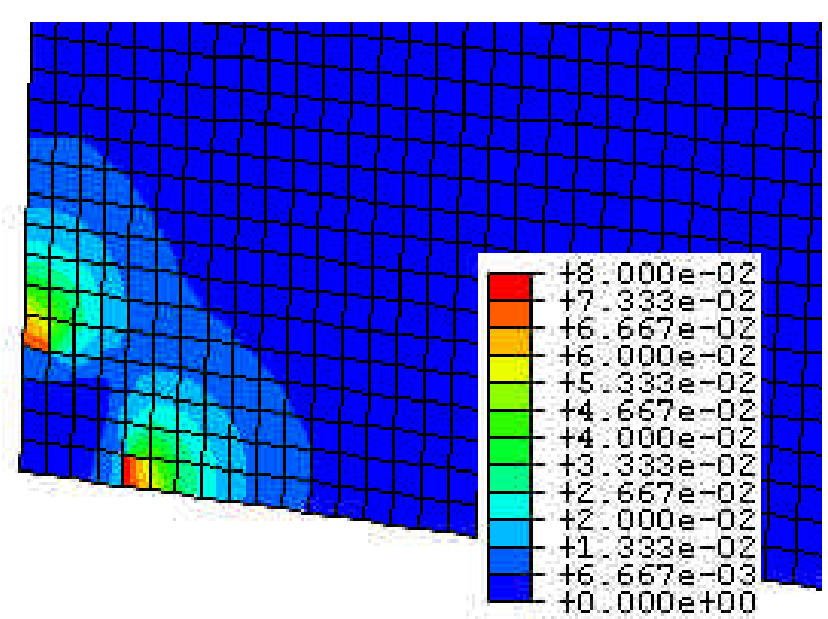

Figura 7.18 - Distribuição das tensões $\left(\mathrm{kN} / \mathrm{cm}^{2}\right)$ na face superior da placa isolada, com força de $62 \mathrm{kN}$, no canto

A adição de barras de transferência nas juntas do pavimento modifica as condições de contorno e altera os esforços gerados na placa. Na figura 7.19 são mostrados os diagramas força - deslocamento, para placas isoladas e para placas com juntas $100 \%$ eficientes. Uma junta $100 \%$ eficiente significa que 0 deslocamento em cada ponto da placa descarregada é igual ao deslocamento no ponto adjacente na placa carregada.

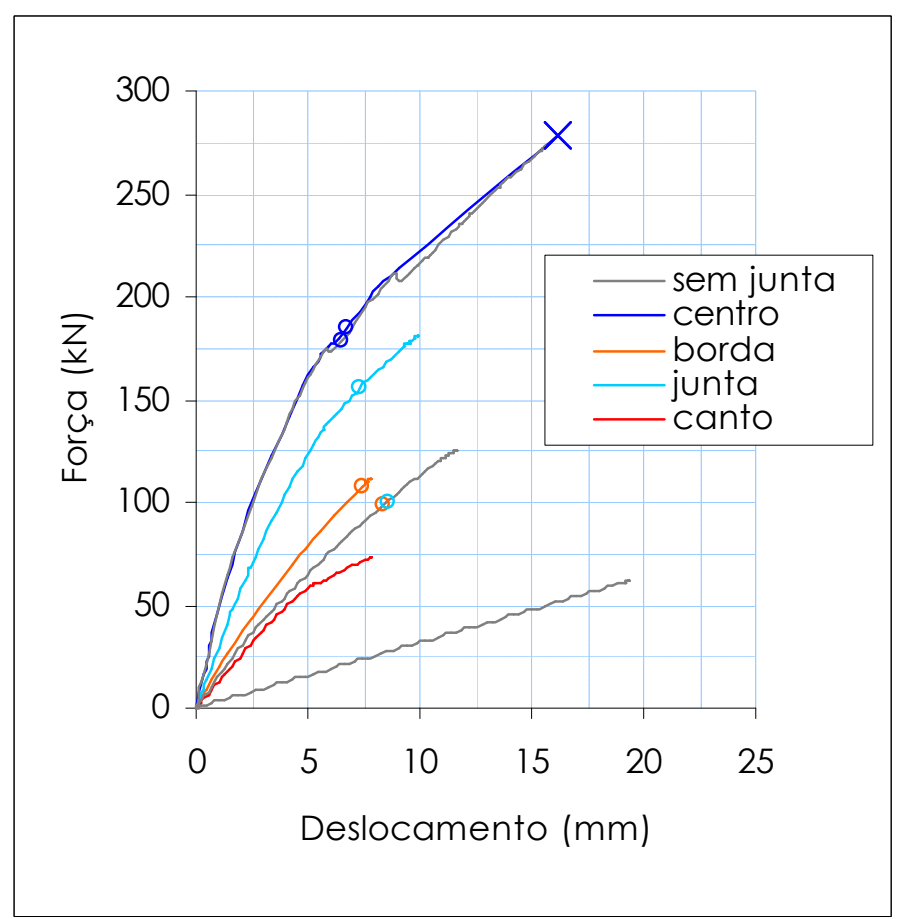

Figura 7.19 - Diagramas força - deslocamento máximo na placa isolada e na placa com juntas de transferência

O comportamento da placa submetida a forças no centro permanece praticamente inalterado. A rigidez das placas adjacentes não é suficiente para impedir o levantamento das bordas, conforme é mostrado na figura 7.20. Caso 
não fosse utilizado modelo de contato e as molas fossem acopladas aos nós da placa de concreto, o efeito da junta seria mais pronunciado, mas não corresponderia à realidade.

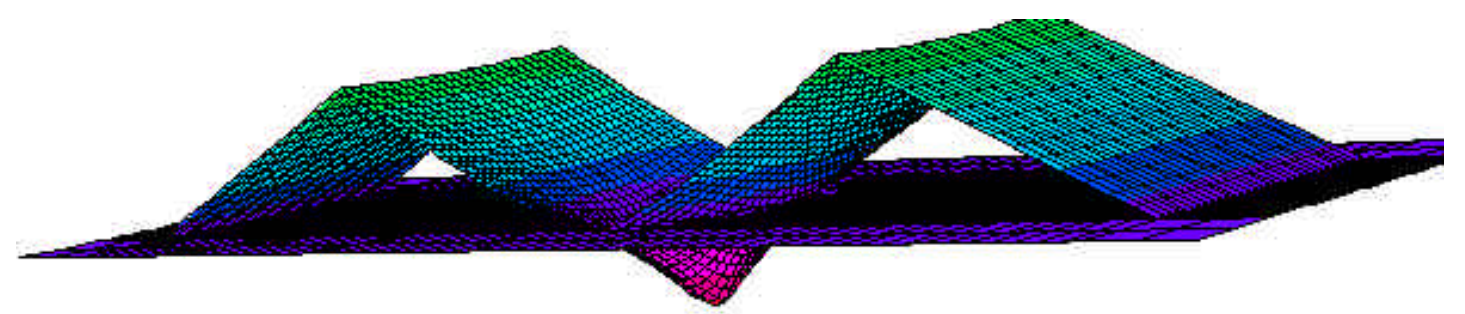

Figura 7.20 - Deformada da placa com juntas de transferênca e força aplicada no centro

Para a força tangente à junta, observa-se uma melhora significativa na resistência. Essa força passa a ter um comportamento mais próximo do de força centrada do que de força na junta da placa isolada. As curvas de força no centro e de força na junta com transferência de deslocamentos não são iguais porque, no caso da junta, são transmitidos os deslocamentos verticais, mas a rotação e os deslocamentos horizontais são livres. Na figura 7.21 são mostradas as tensões na face superior da placa com força tangente à junta. Quando a força atinge 181 kN, aparecem fissuras nas faces superiores das placas, tanto da carregada quanto da adjacente.

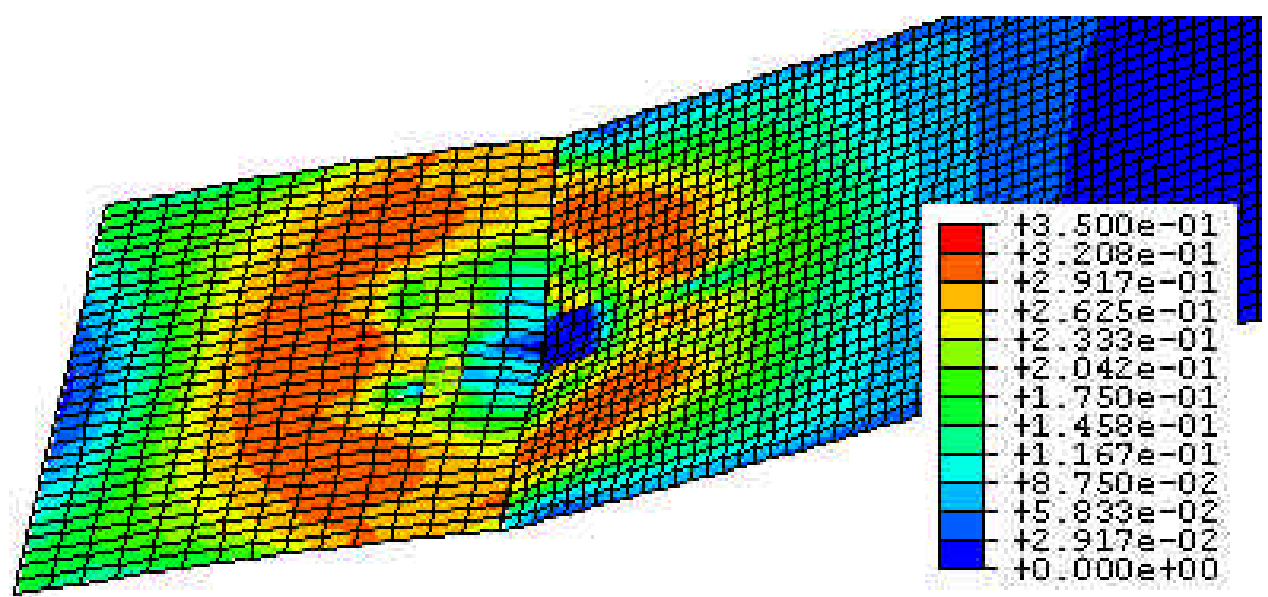

Figura 7.21 - Distribuição das tensões $\left(\mathrm{kN} / \mathrm{cm}^{2}\right)$ na face superior, com força de $181 \mathrm{kN}$ tangente à junta

Para força no canto da placa, é observado um aumento significativo na rigidez da placa com junta, em relação à rigidez da placa isolada. No início do carregamento, o comportamento se aproxima do da força na borda. Quando a força atinge $73 \mathrm{kN}$, aparecem fissuras na face superior. As tensões na armadura se 
mantêm muito abaixo da tensão de plastificação, mas são observadas tensões de tração na face superior, conforme indicado na figura 7.22.

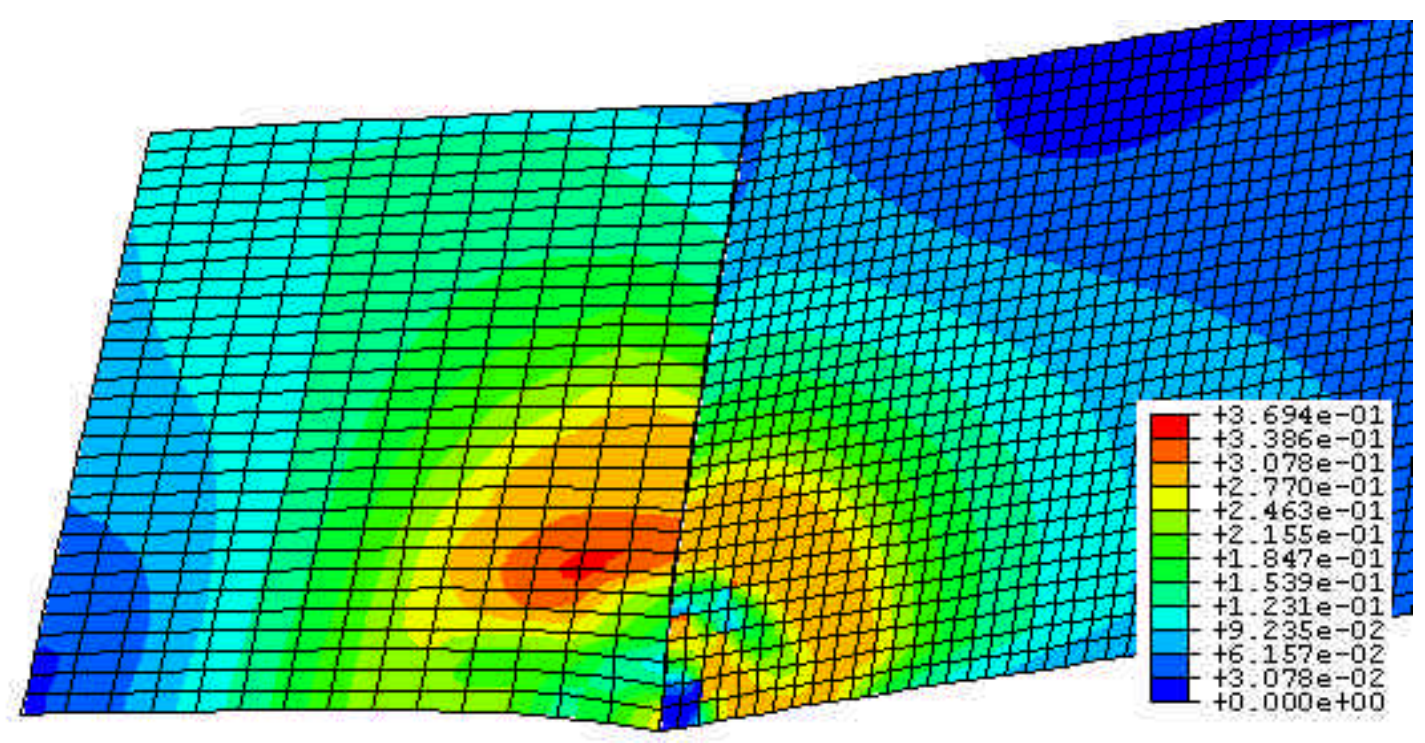

Figura 7.22 - Distribuição das tensões na placa com transferência de deslocamentos na junta, força de $73 \mathrm{kN}$ na junta, $\mathrm{kN} / \mathrm{cm}^{2}$

Caso haja aplicação de força em diferentes posições da placa, simultaneamente, a distribuição de esforços é alterada. A seguir será analisado um caso hipotético de a força ser aplicada ao mesmo tempo no centro, no canto, na junta e na borda da placa. Na figura 7.23 é plotado o diagrama força-deslocamento máximo da placa, com força aplicada nas quatro posições, simultaneamente.

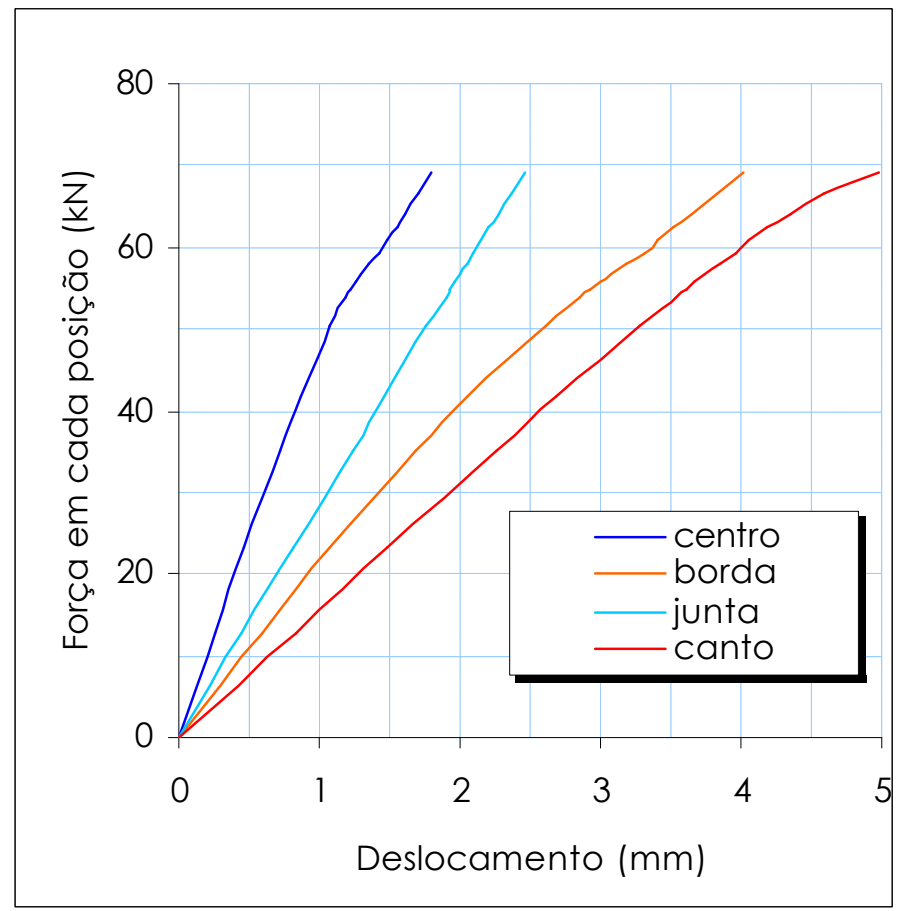

Figura 7.23 - Diagramas força-deslocamento máximo na placa, com força nas quatro posições simultaneamente 
No início do carregamento há uma concentração das tensões de tração abaixo das áreas de aplicação da força, conforme mostrado na figura 7.24. Na face superior aparecem pequenas tensões de tração, que podem ser resistidas pelo concreto (figura 7.25).

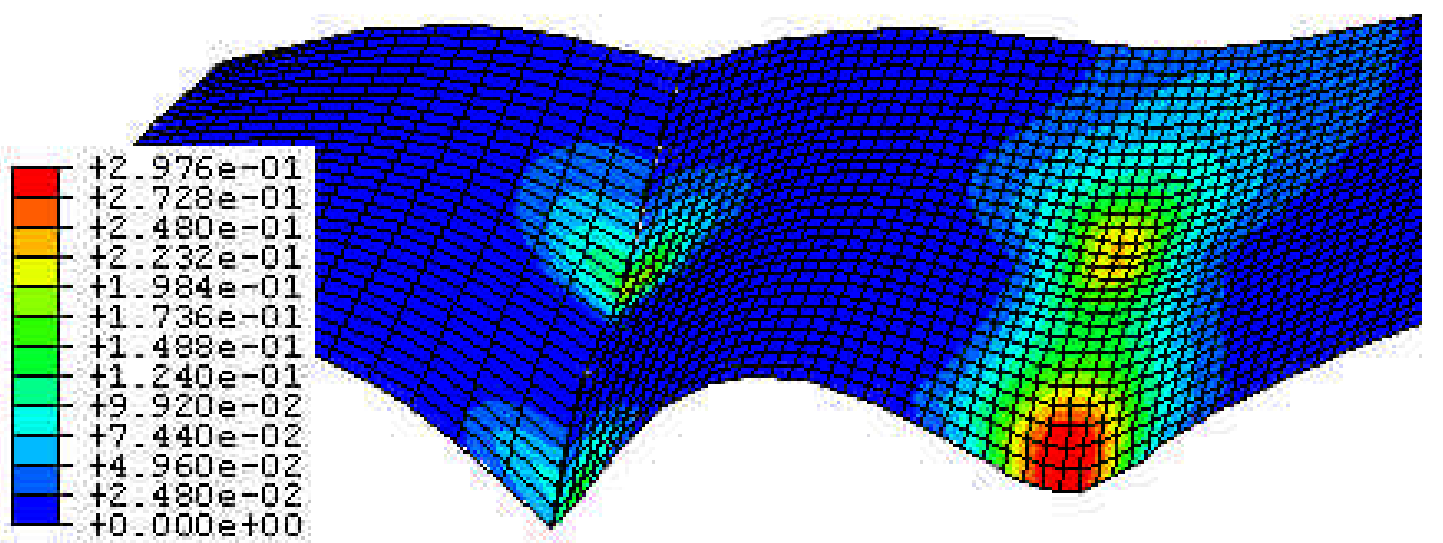

Figura 7.24 - Distribuição das tensões $\left(\mathrm{kN} / \mathrm{cm}^{2}\right)$ na face inferior da placa com transferência de deslocamentos na junta, força de $23 \mathrm{kN}$ nas quatro posições

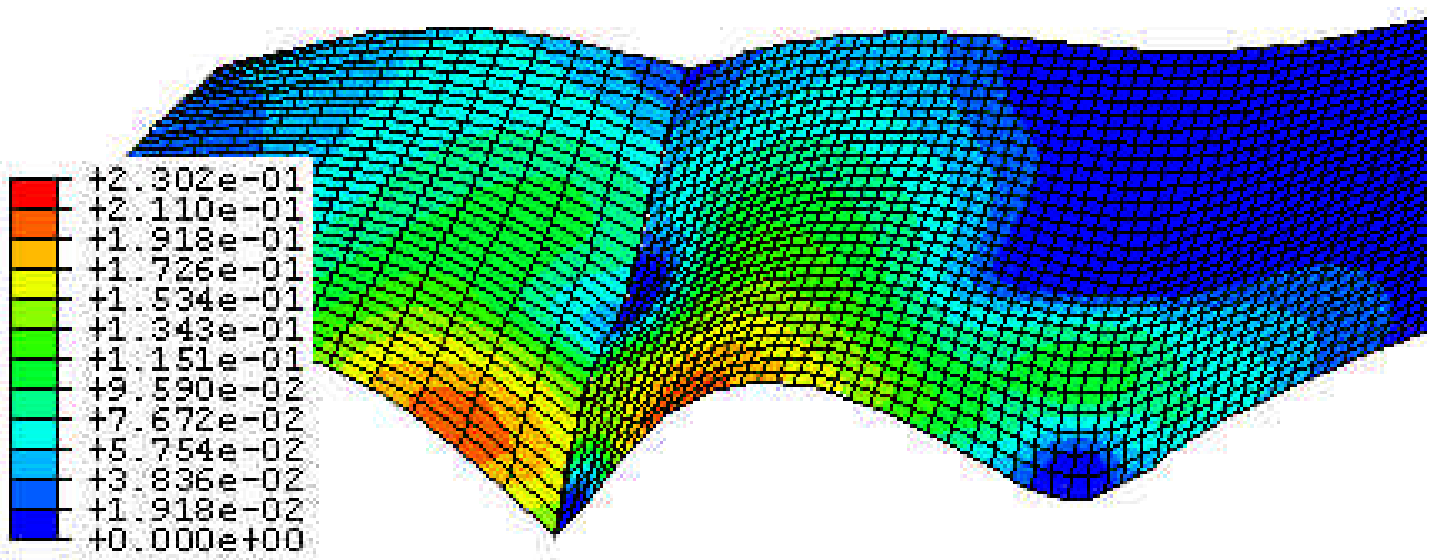

Figura 7.25 - Distribuição das tensões $\left(\mathrm{kN} / \mathrm{cm}^{2}\right)$ na face superior da placa com transferência de deslocamentos na junta, força de $23 \mathrm{kN}$ nas quatro posições

Com o aumento da força, começam a aparecer fissuras na face inferior e os esforços de tração são transmitidos para a armadura (figura 7.26). Na face superior, a tração ainda é resistida pelo concreto (figura 7.27). 


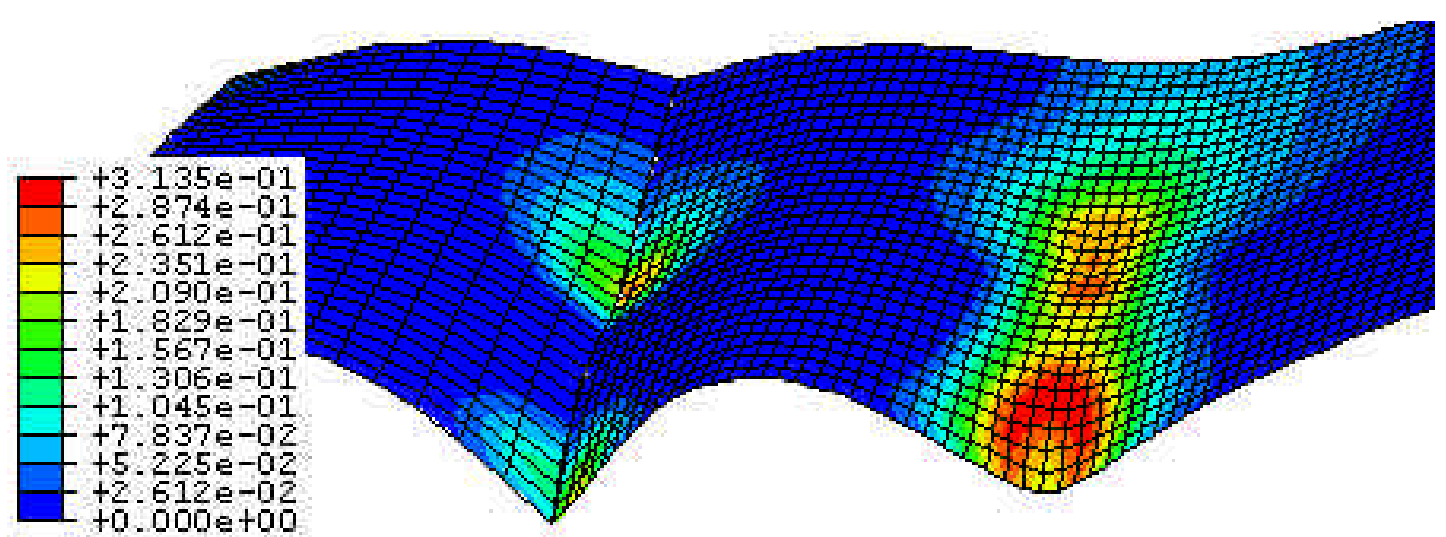

Figura 7.26 - Distribuição das tensões $\left(\mathrm{kN} / \mathrm{cm}^{2}\right)$ na face inferior da placa com transferência de deslocamentos na junta, força de $35 \mathrm{kN}$ nas quatro posições

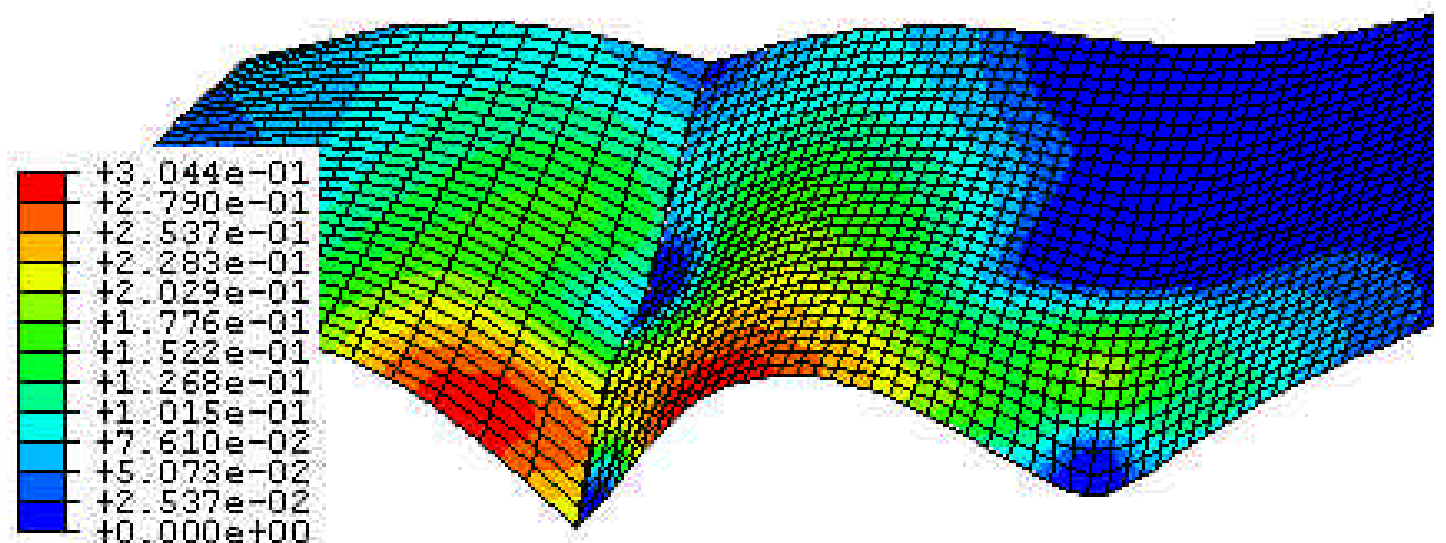

Figura 7.27 - Distribuição das tensões $\left(\mathrm{kN} / \mathrm{cm}^{2}\right)$ na face superior da placa com transferência de deslocamentos na junta, força de $35 \mathrm{kN}$ nas quatro posições

Aumentando ainda mais a força, as tensões na face inferior se redistribuem, conforme figura 7.28 e aumentam as tensões de tração na face superior, entre os pontos de aplicação da força (figura 7.29). Com a força de 69 kN, aplicada em cada uma das posições, surgem fissuras na face superior. Para resistir a carregamentos maiores seria necessário aumentar a espessura da placa ou introduzir armadura dupla. 


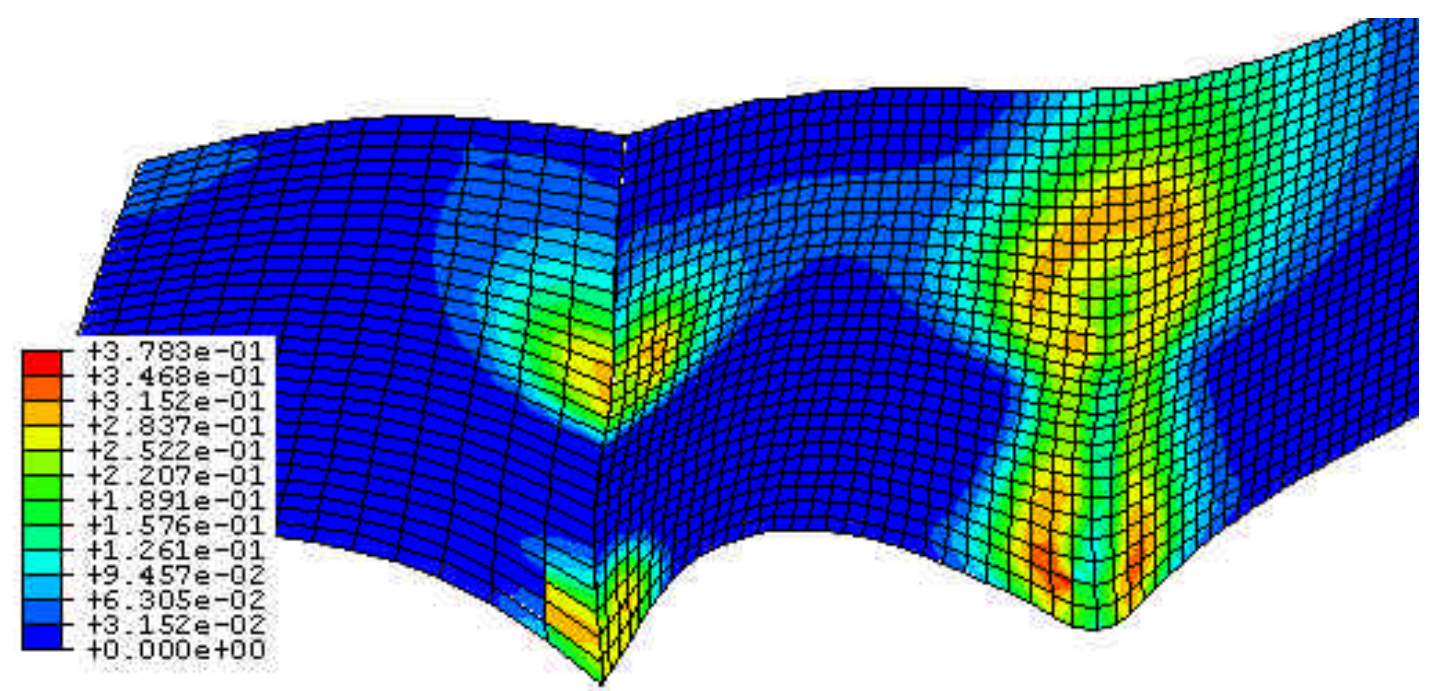

Figura 7.28 - Distribuição das tensões $\left(\mathrm{kN} / \mathrm{cm}^{2}\right)$ na face inferior da placa com transferência de deslocamentos na junta, força de $69 \mathrm{kN}$ nas quatro posições

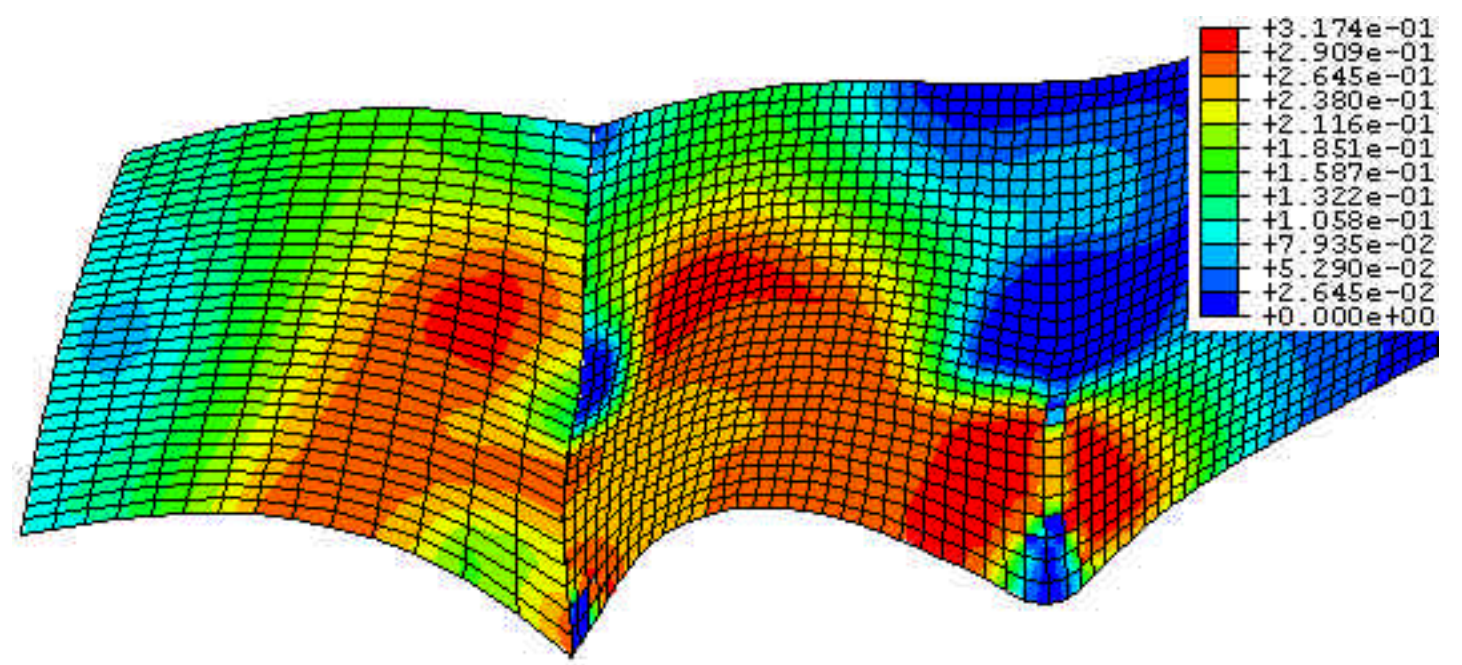

Figura 7.29 - Distribuição das tensões $\left(\mathrm{kN} / \mathrm{cm}^{2}\right)$ na face superior da placa com transferência de deslocamentos na junta, força de $69 \mathrm{kN}$ nas quatro posições

CONSIDERAÇÕES FINAIS

Observa-se que a modelagem numérica é um instrumento poderoso no estudo do comportamento de pavimentos de concreto armado, mas ainda possui limitações. O aparecimento de fissuras em regiões sem armadura, por exemplo, produz instabilidades e o modelo pára de convergir. Outra limitação encontrada foi a necessidade de se estipularem valores para a curva tensão-deformação pósfissuração do concreto, que tem grande influência nos resultados da modelagem e deve ser determinada para cada caso. Como os ensaios de flexão para 
determinação dessa curva foram realizados apenas para armadura simples, limitou-se a análise numérica a esta condição.

Quanto ao comportamento dos pavimentos armados com tela soldada sob carregamento cíclico, observou-se o fenômeno da fadiga e verificou-se que o número de ciclos que a estrutura resiste depende da deformação imposta à armadura. 



\section{CONCLUSÕES}

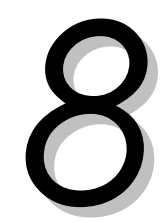

Neste trabalho foram realizados ensaios estáticos e dinâmicos em vigas biapoiadas e em placas uniformemente apoiadas, armadas com tela soldada, com os quais pôde-se traçar algumas conclusões importantes a respeito do comportamento dos pavimentos de concreto estruturalmente armados.

Em adição ao trabalho experimental, foi desenvolvida modelagem numérica, com auxílio de programa com base no método dos elementos finitos. O modelo numérico foi validado pelos resultados experimentais e permitiu o estudo de diversos parâmetros que influenciam na resposta dos pavimentos de concreto estruturalmente armados, às ações verticais.

Os resultados dos ensaios estáticos em placas de concreto simples e de concreto armado mostraram que a presença da armadura próxima à face inferior proporciona um aumento significativo na resistência do pavimento, quando solicitado por forças verticais que provocam momento fletor positivo. Nos modelos ensaiados, nos quais foi aplicada uma única força centrada, distribuída em área quadrada de $20 \mathrm{~cm}$ de lado, esse ganho foi da ordem de $60 \%$. O aumento da força última em virtude da adição de armadura depende da geometria e das condições de utilização do pavimento. Com a modelagem numérica pôde-se observar que, nos casos em que existem momentos fletores negativos de grande intensidade e não se deseja o aparecimento de fissuras na superfície do pavimento, é preciso aumentar a espessura das placas, a fim de permitir que o concreto resista às tensões de tração que aparecem na face superior. Desta forma a armadura positiva contribui muito pouco para a resistência do pavimento.

A placa de concreto simples, ao ser solicitada por carregamento monotônico centrado, atinge a ruína com a mesma força que provoca a fissuração do concreto. O modelo estudado se dividiu em quatro partes, por fissuras que se estendiam do centro às laterais da placa, caracterizando a ruína por flexão. 
A configuração das fissuras nas placas de concreto armado, ensaiadas sob carregamento estático, mostra que ocorreu a ruína por flexão. As primeiras fissuras, observadas nas laterais das placas, são radiais. Essas fissuras se desenvolvem na face inferior. Numa força próxima à força última, aparece uma fissura circunferencial, a uma distância de aproximadamente $40 \mathrm{~cm}$ do centro da placa. Nesse estágio a placa ainda absorve incrementos de força. Após a formação dessa circunferência, foram observados dois comportamentos diferentes nos modelos PCA2 e PCA3. O modelo PCA2 desenvolveu outra fissura adjacente à área de aplicação da força e parou de absorver carga quando houve o afundamento dessa área. No modelo PCA3, após o aparecimento da fissura circunferencial a $40 \mathrm{~cm}$ do centro da placa, desenvolveu-se uma fissura radial crescendo do centro em direção a uma das laterais. A força máxima no modelo PCA2 foi de 118,98 kN, e, no modelo PCA3, de 110,31 kN. No modelo PCA3, a primeira fissura foi observada numa força inferior à do modelo PCA2, porém, o modelo PCA3 pertence à primeira concretagem, que tem concreto mais resistente que o do modelo PCA2. Conclui-se, portanto, que houve uma falha na uniformização do apoio da placa PCA3 e que o modelo PCA2 representa melhor o comportamento de placas de concreto armado uniformemente apoiadas. Isso pode ser confirmado nos gráficos força - deformação na armadura dos dois modelos, nos quais se observa que no modelo PCA2 os deslocamentos crescem uniformemente nos quatro fios, diferente do que acontece no modelo PCA3.

Quando uma força é aplicada repetidas vezes sobre uma placa de concreto armado, as deformações vão aumentando até um instante em que se observa a ruína, sem que a força máxima, para um carregamento estático, tenha sido atingida. Nos ensaios dinâmicos em placas de concreto armado, observou-se a fadiga do aço. Portanto, métodos de dimensionamento que desconsiderem a fadiga da armadura estão contra a segurança. Verificou-se que a ruptura do primeiro fio não representa a ruína da peça, pois ocorre redistribuição das tensões e há um incremento no número de ciclos, até que novos fios se rompam.

Não foi encontrado na literatura nenhum método de dimensionamento de pavimentos de concreto estruturalmente armados que leve em conta o efeito da fadiga. A NBR 6118:2003 apresenta uma metodologia de verificação da fadiga direcionada para vigas de pontes. Os valores de curva S-N apresentados pela Norma foram determinados para aço CA-50, mas as telas soldadas são construídas com aço CA-60. A NBR 6118:2003 indica que, para verificação da 
fadiga, as tensões na armadura podem ser determinadas em regime linear, calculando as tensões do aço em função de suas deformações, considerando a relação entre o módulo de elasticidade do aço e do concreto igual a 10. Neste trabalho foi desenvolvido modelo numérico que pode ser usado para determinação das tensões no concreto e no aço, realizando análise não-linear.

Dos ensaios de fadiga, verificou-se que quanto maior o intervalo entre a tensão máxima e a mínima, menor o número admissível de ciclos. Quando é atingida a tensão de escoamento do aço, a resistência à fadiga depende da deformação na armadura. Mesmo que a variação de tensão no aço seja constante, o número de ciclos que a estrutura é capaz de resistir depende do grau de deformação.

Foram ensaiadas, em laboratório, vigas de concreto armadas com telas soldadas. Foram estipulados valores para a curva tensão - deformação após a fissuração para concreto simples e três áreas de aço diferentes. A obtenção desses dados permitiu o desenvolvimento do modelo numérico, variando a área de aço. Não foi encontrada uma regra para determinação desses valores, em função da área de aço; portanto, a modelagem fica restrita às condições de ensaio.

O modelo numérico desenvolvido neste trabalho representa bem o comportamento dos pavimentos de concreto estruturalmente armados, sob forças estáticas verticais, levando em conta fatores importantes como o contato entre placas e solo, fissuração do concreto, presença da armadura e comportamento pós-fissuração. Foram negligenciados: os efeitos da curvatura em virtude do gradiente de temperatura; as tensões por causa do impedimento da retração e à variação térmica; e a perda de suporte da fundação.

Foi realizada análise paramétrica em que se procurou estudar alguns aspectos importantes no dimensionamento de pavimentos de concreto estruturalmente armados. Dessa análise pôde-se concluir:

- Conforme aumenta o módulo de reação do solo, o deslocamento final no centro da placa diminui, enquanto o levantamento final das bordas aumenta. Para uma mesma força, tanto os deslocamentos no centro quanto no canto diminuem, para um módulo de reação maior. 
- A relação incremento de força última - incremento de k não é linear. O ganho na força última não depende apenas da variação de k, mas também de seu valor inicial.

- Quanto à espessura da placa, observou-se uma relação linear entre o incremento na espessura e o aumento de força última, independente do módulo de reação do solo.

- A introdução de armadura positiva aumenta razoavelmente a resistência da placa com carga centrada, mas o aumento da força última não é proporcional ao aumento da área de aço. $O$ resultado numérico depende muito dos valores da curva tensão deformação pós-fissuração, adotados no modelo. Portanto, é muito importante a execução de ensaios para a calibragem desses valores, de acordo com a geometria e a área de aço empregada.

- Verifica-se que, para mesma espessura e mesma área de aço, as dimensões em planta influenciam substancialmente os esforços na placa. Para os modelos estudados, foi encontrada diferença de até $28 \%$ na força última. Considerando uma força aplicada no interior da placa, os modelos que consideram placa semi-infinita estão a favor da segurança.

- Verifica-se que, para a geometria estudada, a força que provoca a plastificação da armadura é $68 \%$ maior quando a força é aplicada no centro da placa, se comparada com a força na borda ou na junta sem dispositivos de transferência de deslocamentos.

- Quando a força é aplicada na borda ou na junta, aparecem tensões de tração na face superior, capazes de fissurar o concreto. A força última fica limitada por essas tensões, e não pela deformação excessiva da armadura. A espessura da placa deve ser determinada em função dessas tensões. Caso se permita o aparecimento de fissuras na superfície, é possível introduzir armadura na face superior, a fim de controlar a abertura dessas fissuras. 
- No caso da força aplicada no canto de uma placa isolada, as tensões na armadura se mantêm muito baixas, não atingindo a plastificação. Ocorrem grandes deslocamentos, mesmo para forças pequenas, pois se observa movimento de corpo rígido.

- Quando são introduzidas juntas com transferência de deslocamentos, o comportamento da placa submetida a forças no centro permanece praticamente inalterado. A junta não impede o levantamento das bordas, pois o modelo permite 0 descolamento entre a placa e o solo.

- Para a força tangente à junta, observa-se uma melhora significativa na resistência da placa com junta. Ela passa a ter um comportamento mais próximo da força centrada do que o de força na junta da placa isolada. As curvas de força no centro e de força na junta com transferência de deslocamentos não são iguais porque, no caso da junta, são transmitidos os deslocamentos verticais, mas a rotação e os deslocamentos horizontais são livres. Ainda aparecem tensões de tração na face superior, capazes de fissurar a placa, antes que haja deformação excessiva da armadura.

- No canto da placa também é observado um incremento significativo na resistência, quando é utilizada a junta com transferência de deslocamentos. No início, o comportamento se aproxima do de força na borda, mas, com o aumento da força, a inclinação da curva força - deslocamento aumenta e passa a ser paralela à da placa isolada com força no canto. As tensões na armadura se mantêm muito abaixo da tensão de plastificação.

Os ábacos desenvolvidos por Pickett \& Ray, e apresentados por Yoder \& Witczsak (1975), que são utilizados no dimensionamento de pavimentos de concreto, permitem a determinação dos momentos fletores positivos, que, no caso dos pavimentos de concreto simples representam a pior situação. A utilização de armadura, com objetivos estruturais, permite a redução da espessura da placa. Portanto, a simples verificação do momento positivo não garante que não 
aparecerão fissuras na superfície por causa dos momentos negativos que são observados entre os pontos de aplicação da força.

Com base nos resultados obtidos neste trabalho, pôde-se traçar algumas diretrizes para o dimensionamento de pavimentos de concreto estruturalmente armados. São elas:

- Quando não se admitir o aparecimento de fissuras na face superior, os esforços em virtude dos momentos negativos devem ser utilizados para determinar a espessura da placa. No caso onde esses momentos são oriundos de carregamentos móveis com grande número de repetições, deve-se adotar um modelo de fadiga para o concreto tracionado, a fim de determinar 0 número de ciclos admissível. Caso esse número seja insuficiente, deve-se aumentar a espessura da placa. Modelos de fadiga para o concreto tracionado foram apresentados no capítulo 2.

- As tensões na armadura devem ser determinadas considerando o concreto fissurado. Nos casos em que haja carregamento repetido, podem ser usados diagramas S-N para determinar $\mathrm{O}$ número de repetições admissível, para a área de aço escolhida. Caso a área de aço seja insuficiente, deve-se repetir a análise, com área maior de aço.

- Caso a estrutura, durante sua vida útil, possa ser submetida a alguns ciclos de carregamento com força mais elevada que a usual, pode-se fazer a verificação da fadiga, para esses carregamentos, limitando a deformação do aço. O dano provocado por essas solicitações deve ser acumulado ao dano provocado pelos demais carregamentos.

O modelo numérico fornece uma grande flexibilidade à análise estrutural. Com esse instrumento é possível avaliar diversas posições do carregamento e diferentes condições de contorno, a fim de encontrar o projeto mais seguro e mais econômico. 
A NBR 61 18:2003 fornece valores para a curva S-N para aço CA-50. Sugere-se ensaios de fadiga em vigas armadas com telas soldadas, a fim de traçar curvas que sejam aplicáveis às telas com aço CA-60.

A fim de levar em conta o efeito da fadiga no dimensionamento de pavimentos de concreto estruturalmente armados, é possível determinar as tensões no aço, utilizando o modelo numérico apresentado no capítulo 6 associado à curva S-N traçada a partir dos valores experimentais. Para forças que provoquem a plastificação da armadura, é necessário relacionar o número de ciclos com a deformação, que também pode ser determinada numericamente. Não foi encontrado um modelo de fadiga em função das deformações, portanto propõese a execução de mais ensaios com forças repetidas e tensões elevadas na armadura, a fim de se fazer um tratamento probabilístico e fornecer valores que possam ser usados no dimensionamento.

O modelo numérico desenvolvido considera apenas forças estáticas. Para verificação da fadiga, deve-se associar as tensões determinadas numericamente às curvas S-N. Outra forma de modelar o fenômeno da fadiga seria por meio de modelo de Dano. Alguns programas já permitem a consideração de perda de rigidez em função do número de ciclos, para materiais como o aço, por exemplo. Não foi encontrado um programa que permita essa análise associada ao material "concreto". Sugere-se esta implementação em novas pesquisas na área de métodos numéricos.

Neste trabalho foram estudadas, experimentalmente, placas isoladas com armadura simples e força centrada. A mesma metodologia pode ser empregada em trabalhos futuros no estudo de placas com ou sem juntas, com armadura simples e dupla e com diferentes posições da força.

Foram determinados valores para a curva tensão-deformação pós fissuração do concreto, necessários para a modelagem numérica. Esses valores foram determinados para a geometria das placas deste trabalho. Sugerem-se mais ensaios, com diferentes geometrias e áreas de aço, que forneçam valores para modelagem de outros tipos de estrutura. 
Propõe-se a utilização do modelo numérico, desenvolvido neste trabalho, numa análise paramétrica, variando outros fatores, além dos mostrados nesta tese, como: tipos de eixos, camadas do solo e da sub-base, perda de suporte, e curvatura devida aos efeitos de temperatura. Com uma extensa análise paramétrica, pode-se chegar a ábacos ou equações que permitam o dimensionamento para casos típicos, lembrando que os ábacos sempre devem deixar claro suas limitações, pois o número de possibilidades é muito grande, e é praticamente impossível definir um método que se aplique a todos os casos. 


\section{BIBLIOGRAFIA}

REFERÊNCIAS BIBLIOGRÁFICAS

AAS-JAKOBSEN, L. (1970). Fatigue of concrete beams and columns. Division of Concrete Structures, NTH, Trondheim. (Bulletin no 70-1)

AGARWAL, A. C.; BIRKEMOE, P. C.; GOEL, A. P.; SWEENEY, R. A. P.; THOMPSON, J. C.; TOPPER, T. H. (1994). Issues in structural fatigue design and evaluation. Canadian Journal of Civil Engineering, p. 903-912, Dec.

AL-KHALID, H. (1991). The behavior of precast concrete raft pavements under fatigue loading with special reference to their use in port areas. In: BULL, J. W., ed. Precast concrete raft units. Glasgow, Blackie and Son. Cap. 4, p.51-100.

AMERICAN CONCRETE INSTITUTE (1992). ACI 215R-74 - Considerations for design of concrete structures subjected to fatigue loading. Detroit, $\mathrm{ACl}$.

ANDERSON, T. L. (1991). Fracture mechanics fundamentals and applications. CRC Press, Inc., Boca Raton, Florida.

ASSOCIAÇÃO BRASILEIRA DE NORMAS TÉCNICAS. NBR 8681: 1984 - Ações e segurança nas estruturas. Rio de Janeiro.

ASSOCIAÇÃO BRASILEIRA DE NORMAS TÉCNICAS. NBR 6118:2003 - Projeto de estruturas de concreto. 
BALAGURU, P. (1992). Prediction of the effect of fatigue loading on the serviceability of reinforced and prestressed concrete members. In: INTERNATIONAL SYMPOSIUM ON FATIGUE AND FRACTURE IN STEEL AND CONCRETE STRUCTURES, Madras-Índia, 1991. Proceedings. Rotterdam, A. A. Balkema. v. 1, p. 381-405.

BALÁzS, György (1991). Fatigue of bond. ACl Material Journal, n. 88-M64, p. 620629, Nov-Dec.

BALBO, José Tadeu (1999). Contribuição à análise estrutural de reforços com camadas ultradelgadas de concreto de cimento portland sobre pavimentos asfálticos (whitetopping ultradelgados). São Paulo. 195p. Tese (Livre Docência) Escola Politécnica - Universidade de São Paulo.

BARKER, W. R. (1981). Introduction to a rigid pavement design procedure. In: INTERNATIONAL CONFERENCE ON CONCRETE PAVEMENT DESIGN, 2., West Lafayette, 1981. West Lafayette, Purdue University. p. 135-148.

BARSON, J. M.; ROLFE, S. T. (1987). Fracture \& fatigue control in structures. New Jersey, Prentice-Hall, 2 ed.

BELLETTI, Beatrice; CERIONI, Roberto; IORI, Ivo (2001). Physical approach for reinforced-concrete (parc) membrane elements. Journaul of structural engineering, v. 127, n. 12, p. 1412-1426, Dec.

BRAGUIM, José Roberto (1995). O comportamento em serviço de vigas de concreto armado sob carregamento cíclico. São Paulo. 114p. Tese (Doutorado) Escola Politécnica - Universidade de São Paulo.

BUCH, N. (1999). Factors affecting load across transverse joints in jointed concrete pavements. In: Recent Developments in the Design and Specification of Concrete Pavements Systems. SP-181, ACl.

BULL, John W., (1986). An analytical solution to the design of precast concrete pavements. International Journal of Numerical Analytic Methods Geomechanics n. 10, p. 115-123. 
BULL, J. W.; LUHESHI, Y. B. (1989). The experimental and finite element analysis of non-square raft type concrete pavements. In.: INTERNATIONAL SYMPOSIUM ON NUMERICAL MODELS IN GEOMECHANICS, 3., Niagara Falls, 1989. Proceedings. Niagara Falls. p. 707-715.

BULL, John W., ed. (1991a). Precast concrete raft units. 2.ed. Glasgow, Blackie and Son.

BULL, John W. (1991b). The violation of Westergaard's full contact assumption and its effect on raft unit pavements. Computers and Geotechinics, v. 12, p. 133-147.

BULL, John. W.; SALMO, Salim H. (1992). Fatigue characteristics of precast concrete raft pavement units used for heavy duty pavements. In: INTERNATIONAL SYMPOSIUM ON FATIGUE AND FRACTURE IN STEEL AND CONCRETE STRUCTURES, Madras-Índia, 1991. Proceedings. Rotterdam, A. A. Balkema. v. 1, p. 381-405.

BULL, J. W.; WOODFORD, C. H. (1997). Design of precast concrete pavement units for rapid maintenance of runways. Computers \& Structures, v.64, n.1-4, p.857-864.

BULL, J. W.; WOODFORD, C. H. (1998). The use of steel edge surrounds to reduce stress and displacement in concrete pavements. Computers \& Structures, v.68, p.251-260.

CARLTON, P. F.; BEHRMANN, R. M. (1958). Model studies of prestressed rigid pavements for airfields. Highway research board, National Research Council, Washington. (Bulletin no 179, p. 32).

CHILDS, L. D. (1945). A model study of slab action in concrete pavements. In: HIGHWAY RESEARCH BOARD, NATIONAL RESEARCH COUNCIL, Washington, 1945. Proceedings. Washington. v. 25, p. 45

CHILDS, L. D.; KAPERNICK, J. W. (1959). Tests to evaluate concrete subbases. Transactions, ASCE. v. 124, p. 556-87.

COMITE EURO-INTERNATIONAL DU BETON (1988). Fatigue of concrete structures State of the art report. Bulletin d'Information, n. 188. 
COMITE EURO-INTERNATIONAL DU BETON (1991a). CEB-FIP Model Code 1990. Bulletin d'Information, n. 203.

COMITE EURO-INTERNATIONAL DU BETON (1991b). CEB-FIP Model Code 1990. Bulletin d'Information, n. 204.

COMITE EURO-INTERNATIONAL DU BETON (1996). RC Elements under cyclic loading. State of art report.

CORNELISSEN, H. A. W.; REINHARDT, H. W. (1984). Uniaxial tensile fatigue of concrete under constant amplitude and programme loading. Magazine of Concrete Research, v. 36, n. 129, p. 216-226.

CREPALDI, Avelino A. P. (2000). Contribuição ao estudo da fadiga do concreto. São Paulo. 126p. Tese (Doutorado) - Escola Politécnica - Universidade de São Paulo.

DARTER, M. I.; BARENBERG, E. J. (1977). Design of zero-maintenance plain jointed concrete pavement - Development of Design Procedures. Federal Highway Administration. (Report no FHWA-RD-77-III, v. 1).

DRIEMEIER, Larissa (1995). Considerações sobre a fadiga em metais e o comportamento do concreto sob solidificação cíclica. 120p. Dissertação (mestrado) - Escola de Engenharia de São Carlos, Universidade de São Paulo.

EL DEBS, Mounir Khalil (2000). Concreto pré-moldado: fundamentos e aplicações. São Carlos, EESC-USP - Projeto REENGE.

GALLOWAY, J. W.; RAITHBY, K. D. (1973). Effects of rate of loading on flexural strength and fatigue performance of concrete. TRRL Report LR547.

HAMDY, Usama Mohamed (1997). A damage-based life prediction model of concrete under variable amplitude fatigue loading. lowa City. 182p. Thesis (PhD) University of lowa. 
HANSON, J. M.; SOMES, M. F.; HELGASON, T. (1974). Investigation of design factors affecting fatigue strength of reinforcing bars - test program. In: ABELES SYMPOSIUM: FATIGUE OF CONCRETE, Hollywood, 1972-1973. Papers. Detroit, ACl Publication SP41. p. 71-106.

HAWKINS, N. M.; HEATON, L. W. (1974). Fatigue characteristics of welded wire fabric. In: ABELES SYMPOSIUM: FATIGUE OF CONCRETE, Hollywood, 1972-1973. Papers. Detroit, ACI Publication SP-41. p. 183-202.

HAWKINS, N. M. (1974a). Fatigue characteristics in bond and shear of reinforced concrete beams. In: ABELES SYMPOSIUM: FATIGUE OF CONCRETE, Hollywood, 19721973. Papers. Detroit, ACI Publication SP-41. p. 203-236.

HAWKINS, N. M. (1974b). Fatigue strength of concrete slabs reinforced with wire fabric. In: ABELES SYMPOSIUM: FATIGUE OF CONCRETE, Hollywood, 1972-1973. Papers. Detroit, ACl Publication SP-41. p. 315-330.

HAWKINS, Neil M.; SHAH, Surendra P. (1982). American Concrete Institute considerations for fatigue. In: IABSE COLLOQUIUM ON FATIGUE OF STEEL AND CONCRETE STRUCTURES, Lausanne, 1982. Proceedings. Zurich, IABSE. p. 41- 50.

HELGASON, T.; HANSON, J. M. (1974). Investigation of design factors affecting fatigue strength of reinforcing bars - statistical analysis. In: ABELES SYMPOSIUM: FATIGUE OF CONCRETE, Hollywood, 1972-1973. Papers. Detroit, ACI Publication SP41. p. 107-138.

HILSDORF, H.; KESLER, C. E. (1960). The behavior of concrete in flexural under varying repeated loads - TAM Report no 172. University of Illinois.

HOLMEN, J. O. (1979). Fatigue of concrete by constant and variable amplitude loading-Bulletin no 79-1. Division of Concrete Structures, NHT, Trondheim.

JHAMB, I. C.; MACGREGOR, J. G. (1974). Stress concentrations caused by reinforcing bar deformations. In: ABELES SYMPOSIUM: FATIGUE OF CONCRETE, Hollywood, 1972-1973. Papers. Detroit, ACI Publication SP-41. p. 169-182. 
KENNEDY, L. J. (1991). Rapid pavement repair using precast concrete rafts. In: BULL, J. W., ed. Precast concrete raft units. Glasgow, Blackie and Son. Cap. 7, p.150-171 .

KIM, Jin-Keun; KIM, Yun-Yong (1996). Experimental study of the fatigue behavior of high strength concrete. Cement and Concrete Research, v. 26, n. 10, p. 1513-1523.

KWAN, W. P.; BILLINGTON, S. L. (2001). Simulation of structural concrete under cyclic load. Journal of structural engineering, v. 127, n. 12, p. 1391-1401.

LLOYD, J. P.; LOTT, J. L.; KESLER, C. E. (1968). Fatigue of concrete - engineering experiment station bulletin no 499. University of Illinois, Urbana-Champaign.

LOSBERG, Anders (1960). Structurally reinforced concrete pavements. Göteborg, Elanders Boktryckeri Aktiebolac.

MALLET, G. P. (1991). Fatigue of reinforced concrete. Transport and Road Research Laboratory - Department of Transport, London.

MCCALL, J. T. (1958). Probability of fatigue failure of plain concrete. Journal of the American Concrete Institute. v. 30, n. 2, p. 233-45.

MINER, M. A. (1945). Cumulative damage in fatigue. Journal of Applied Mechanics. n. 12, p. 159-64.

MURDOCK, J. W.; KESLER, C. E. (1958). Effect of range of stress on fatigue strength of plain concrete beams. Journal of the American Concrete Institute. v. 30, n. 2, p. 221-233.

$\mathrm{OH}, \mathrm{B} . \mathrm{H}$. (1991). Cumulative damage theory of concrete under variable-amplitude fatigue loadings. ACI Material Journal, p. 41-48, Jan-Feb.

OLIVEIRA, P. L. (2000). Projeto estrutural de pavimentos rodoviários e de pisos industriais de concreto. São Carlos, 174p. Dissertação (Mestrado) - Escola de Engenharia de São Carlos, Universidade de São Paulo. 
OWUSU-ANTWI, E.; DARTER, M. (1999). Improved concrete pavement design methodology for better performance. In: ZOLLINGER, D.G., ED. Recent developments in the design and specifications of concrete pavement systems. ACl International, SP-181.

PACKARD, R. G.; TAYABJI, S. D. (1985). New PCA thickness design procedure for concrete highway and street pavements. In: INTERNATIONAL CONFERENCE ON CONCRETE PAVEMENT DESIGN, 3., West Lafayette, 1985. Proceedings. West Lafayette, Purdue University. p. 225-236.

PAFEC. Data preparation user manual, level 6.1. Nottingham, UK.

PALIGA, Charlei Marcelo; REAL, Mauro de Vasconcellos (2003). Análise de pavimentos portuários em laje de concreto armado sob cargas de grande intensidade. In: SIMPÓSIO EPUSP SOBRE ESTRUTURAS DE CONCRETO, 5., São Paulo, 2003. Anais. Universidade de São Paulo, CD-Rom.

PARKER, Jr. F. et al. (1977). Development of a structural design procedure for rigid airport pavements. Federal Aviation Administration, Washington, D. C. (Report no FAA-RD-77-81).

PASKO, T. J. (1973). Fatigue of welded reinforcing steel. ACl Journal, v. 70, p. 757758.

PICKETT, Gerald; RAY, G. K. (1951). Influence charts for concrete pavements. American Society of Civil Engineers, p. 49-73.

RAITHBY, K. D. (1979). Flexural fatigue behavior of plain concrete. Fatigue of Engineering Materials and Structures. v. 2, p. 269-78.

RAITHBY, K. D.; GALLOWAY, J. W. (1974). Effects of moisture condition, age, and rate of loading on fatigue of plain concrete. In: ABELES SYMPOSIUM: FATIGUE OF CONCRETE, Hollywood, 1972-1973. Papers. Detroit, ACI Publication SP-41. p. 15-34.

RODRIGUES, Lezzir F. (2003). Comportamento estrutural de placas de concreto apoiadas sobre base granular. 249 p. Dissertação (mestrado) - Universidade Federal de Goiás. 
RODRIGUES, P. P. F.; PITTA, M.R. (s.d.). Dimensionamento de pavimentos de concreto estruturalmente armados. IBTS.

ROESLER, Jeffery Raphael (1998). Fatigue of concrete beams and slabs. UrbanaChampaign. 483p. Thesis (PhD) - College of the University of Illinois.

ROLLINGS, R. S. (1991). A review of precast concrete pavements and rafts. In: BULL, J. W., ed. Precast concrete raft units. Glasgow, Blackie and Son. Cap. 1, p.1-17.

ROPER, Harold (1982). Reinforcement for concrete structures subject to fatigue. In: IABSE COLLOQUIUM ON FATIGUE OF STEEL AND CONCRETE STRUCTURES, Lausanne, 1982. Proceedings. Zurich, IABSE. p. 239- 245.

SAITO e IMAI (1983). Direct tensile fatigue of concrete by the use of friction grips. ACl Journal. v. 80, n. 5, p. 431-438.

SCHLÄFLI, Max; BRÜHWILER, Eugen (1998). Fatigue of existing reinforced concrete bridge deck slabs. Engineering Structures, v. 20, n. 11, p. 991-998.

SCHÜTZ, W. (1993). The significance of service load data for fatigue life analysis. In: INTERNATIONAL SYMPOSIUM ON FATIGUE DESIGN, Helsinki-Finland, 1992. Proceedings. London, ESIS and MEP. p. 1-17.

SILFWERBRAND, J. (1999). Thermal stresses in square shaped concrete pavements. In: ZOLLINGER, D.G., ED. Recent developments in the design and specifications of concrete pavement systems. ACl International, SP-181.

SORETZ, S. (1974). Contribution to the fatigue strength of reinforced concrete. In: ABELES SYMPOSIUM: FATIGUE OF CONCRETE, Hollywood, 1972-1973. Papers. Detroit, ACI Publication SP-41. p. 35-58.

SPARKS, P. R. (1982). The influence of rate of loadings and material variability on the fatigue characteristics of concrete. ACI Publication, SP-75, p. 331-343.

SPARKS, P. R.; MENZIES. J. B. (1973). The effect of rate of loading upon the static and fatigue strength of plain concrete in compression. Magazine of concrete research. v. 25, n. 83, p. $73-80$. 
SU, E.; HSU, T. (1988). Biaxial compression fatigue and discontinuity of concrete. ACl Material Jouranl. v. 85, n. 3, p. 178-88.

SUBRAMANIAM, Kolluru V. L. (1999). Fatigue of concrete subjected to biaxial loading in the tension region. Evanston. 237p. Thesis (PhD) - Northwestern University.

SURESH, Subra (1991). Fatigue of materials. Cambridge University Press, Cambridge.

SWISS SOCIETY OF ENGINEERS AND ARCHITECTS (1997). SIA Documentation 0133 Fatigue of Concrete Structures, Zurich.

TAKHAR, S. S.; JORDAAN, I. J.; GAMBLE, B. R. (1974). Fatigue of concrete under lateral confining pressure. In: ABELES SYMPOSIUM: FATIGUE OF CONCRETE, Hollywood, 1972-1973. Papers. Detroit, ACI Publication SP-41. p. 59-70.

TEPFERS, R.; HEDBERG, B.; SZCZEKOCKI, G. (1984). Absorption of energy in fatigue loading of plain concrete. Materials and Structures, v. 17, n. 97, p. 59-64.

TEPFERS, R.; KUTTI, T. (1979). Fatigue strength of plain, ordinary, and lightweight concrete. Journal of the American Concrete Institute. v. 76, p. 635-52.

TILLY, G. P.; MOSS D. S. (1982). Long endurance fatigue of steel reinforcement. In: IABSE COLLOQUIUM ON FATIGUE OF STEEL AND CONCRETE STRUCTURES, LaUsanne, 1982. Proceedings. Zurich, IABSE. p. 229- 238.

TRAINA, L. A.; JERAGH, A. A. (1982). Fatigue of plain concrete subjected to biaxialcyclical loading. ACI Publication SP-75. p. 217-34.

VAN LEEUWEN, J.; SIEMES, A. J. M. (1979). Miner's rule with respect to plain concrete. Heron. v. 24, n.1.

VANDENBOSSCHE, Julie Marie (1995). An analysis of the longitudinal reinforcement in a jointed reinforced concrete pavement. East Lansing. 105p. Thesis (PhD) Michigan State University.

WALKER, Wayne W.; HOLLAND, Jerry A. (2001). Design of unreinforced slabs-onground made easy. Concrete International, v. 23, n. 5, p. 37-42, May. 
WESTERGAARD, H. M. (1926). Stress in concrete pavements of airfields. Public Roads, v. 7, p. 25-35, Apr.

YODER, E. J.; WITCZAK, M. W. (1975). Principles of pavement design. 2. ed., New York, John Wiley \& Sons.

ZHANG, Binsheng; WU, Keru (1996). Residual fatigue strength and stiffness of ordinary concrete under bending. Cement and Concrete Research, v. 27, n. 1, p. 115-126.

ZHANG, Binsheng (1998). Relationship between pore structure and mechanical properties of ordinary concrete under bending fatigue. Cement and Concrete Research, v. 28, n. 5, p. 699-711.

ZHANG, Jun; STANG, Henrik; LIA, Victor C. (1999). Fatigue life prediction of fiber reinforced concrete under flexural load. International Journal of Fatigue, v. 21, p. 1033-1049.

\section{BIBLIOGRAFIA COMPLEMENTAR}

AMERICAN SOCIETY FOR TESTING AND MATERIALS (1977). ASTM D 1 196-64 - Standard method for nonrepetitive static plate load tests of soils and flexible pavement components, for use in evaluation and design of airport and highway pavements. Philadelphia.

AWAD, M. E.; GALLOWAY, J. W. (1974). Strength and deformation characteristics of plain concrete subjected to high repeated and sustained loads. In: ABELES SYMPOSIUM: FATIGUE OF CONCRETE, Hollywood, 1972-1973. Papers. Detroit, ACI Publication SP-41. p. 1-14.

BERGSTRÖM, S. G.; FROMÉN, E.; LINDERHOLM, S. (1949). Investigation of whell load stresses in concrete pavements. Cement-och Betonginstitutet, n. 13.

DEPARTAMENTO NACIONAL DE ESTRADAS DE RODAGEM (1989). Manual de pavimentos rígidos. Rio de Janeiro. v. 2. 
IOANNIDES, A. M. (1991). Analytical procedures for concrete pavements. In: BULL, J. W., ed. Precast concrete raft units. Glasgow, Blackie and Son. Cap. 2, p.18-36.

KWAK, H.; KIM, S. (2001). Nonlinear analysis of RC beam subject to cyclic loading. Journal of Structural Engineering, v. 127, n. 12, p. 1436-1444, Dec.

PANONTIN, T. L.; SHEPPARD, S. D., eds (1999). Fatigue and fracture mechanics. (Papers presented 29th National Symposium on Fatigue and Fracture Mechanics, Stanford, 1997). West Conshohocken, PA, ASTM. (STP 1332).

RAMAKRISHNAN, V.; LOKVIK, Bijorn J. (1992). Fatigue strength and endurance limit of plain and fibre reinforced concretes - a critical review. In: INTERNATIONAL SYMPOSIUM ON FATIGUE AND FRACTURE IN STEEL AND CONCRETE STRUCTURES, Madras-Índia, 1991. Proceedings. Rotterdam, A. A. Balkema. v. 1, p. 381-405.

SINGH, S. P.; GAMBHIR, M .L.; KUKREJA, C. B. (1992). Fatigue behavior of fibre reinforced concrete. In: INTERNATIONAL SYMPOSIUM ON FATIGUE AND FRACTURE IN STEEL AND CONCRETE STRUCTURES, Madras-Índia, 1991. Proceedings. Rotterdam, A. A. Balkema. v. 1, p. 381-405.

SWARTZ, Stuart E. (1992). Concrete fatigue and fracture - plain and reinforced concrete beams. In: INTERNATIONAL SYMPOSIUM ON FATIGUE AND FRACTURE IN STEEL AND CONCRETE STRUCTURES, Madras-Índia, 1991. Proceedings. Rotterdam, A. A. Balkema. v. 1, p. 407-421.

ZHANG, Binsheng (1997). Residual fatigue strength and stiffness of ordinary concrete under bending. Cement and Research, v. 27, n. 1, p. 115-126. 